\title{
Water Quality of the Lower Columbia River Basin: Analysis of Current and Historical Water-Quality Data through 1994
}

U.S. GEOLOGICAL SURVEY

Water-Resources Investigations Report 95-4294

Prepared in cooperation with the Lower Columbia River Bi-State Water-Quality Program 


\section{Water Quality of the Lower Columbia River Basin: Analysis of Current and Historical Water-Quality Data through 1994}

By Gregory J. Fuhrer, Dwight Q. Tanner, Jennifer L. Morace, Stuart W. McKenzie, and Kenneth A. Skach

U.S. GEOLOGICAL SURVEY

Water-Resources Investigations Report 95-4294

Prepared in cooperation with the

Lower Columbia River Bi-State

Water-Quality Programs

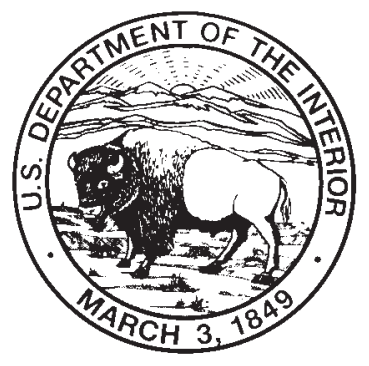

Portland, Oregon

1996 


\section{U. S. DEPARTMENT OF THE INTERIOR BRUCE BABBITT, Secretary}

U.S. GEOLOGICAL SURVEY

Gordon P. Eaton, Director

The use of trade, product, or firm names in this publication is for descriptive purposes only and does not imply endorsement by the U.S. Government.

For additional information

write to:

District Chief

U.S. Geological Survey, WRD

10615 S.E. Cherry Blossom Drive

Portland, Oregon 97216
Copies of this report can be purchased from:

U.S. Geological Survey Earth Science Information Center Open-File Reports Section Box 25286, MS 517 Denver Federal Center Denver, CO 80225 


\section{FOREWORD}

One of the great challenges faced by the Nation's water-resource scientists is providing reliable water-quality information to guide the management and protection of our water resources. That challenge is being addressed by Federal, Tribal, State, interstate, and local water-resources agencies, by academic institutions, and by private industry. Many of these organizations are collecting water-quality data for a host of purposes, including compliance with permits and water-supply standards, development of remediation plans for specific contamination problems, decision of operational procedures for industrial, wastewater, or water-supply facilities, and refinement of research to advance our understanding of water-quality processes. In fact, during the past two decades, tens of billions of dollars have been spent on water-quality data collection programs. Unfortunately, the utility of these data for present and future regional and national assessments is limited by such factors as the areal extent of the sampling network, the frequency of sample collection, the variety of collection and analytical procedures, and the types of water-quality characteristics determined.

The Lower Columbia River Bi-State Water Quality Program, with involvement from private industry, sports and commercial fishing, public ports, environmental groups, municipal, State, Northwest Power Planning Council, and Federal interests, has provided guidance to:

1. Provide a regionally consistent description of water-quality conditions;

2. Define seasonal and long-term trends (or lack of trends) in water quality; and

3. Identify, describe, and explain, as possible, the major factors that affect observed water-quality conditions and trends.

Don Yon, Project Manager

Lower Columbia River Bi-State Water Quality Program 


\section{CONTENTS}

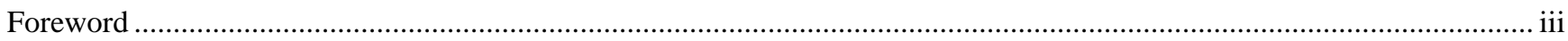

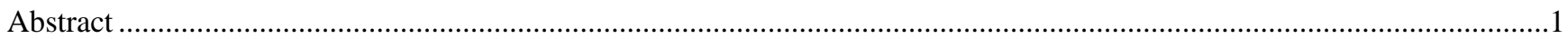

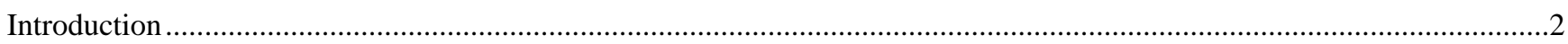

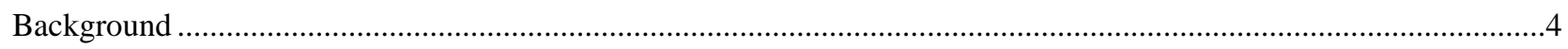

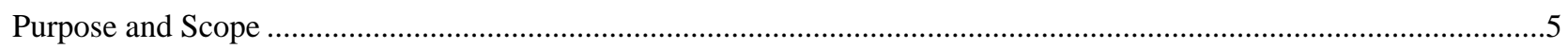

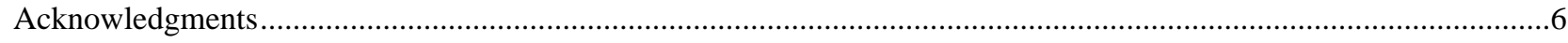

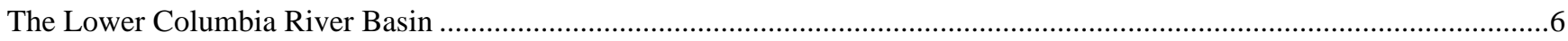

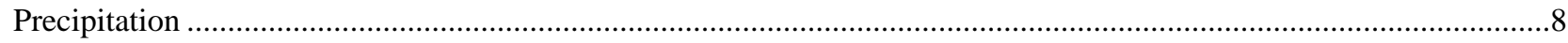

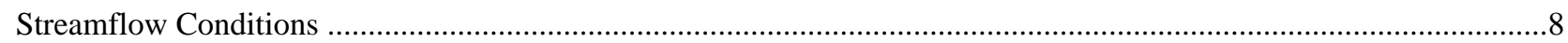

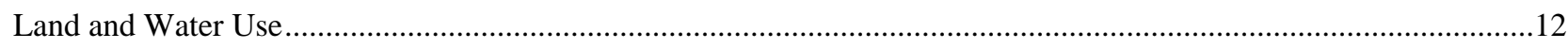

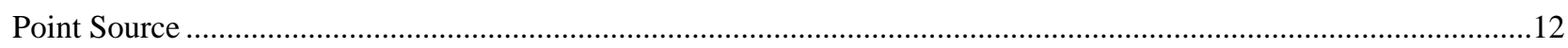

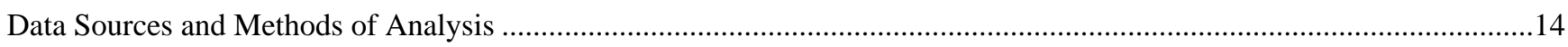

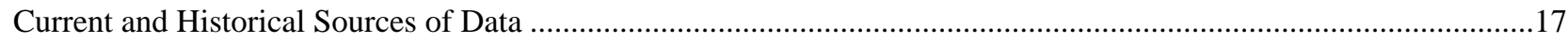

Historical Data .

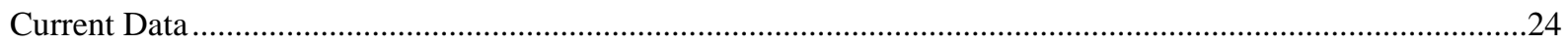

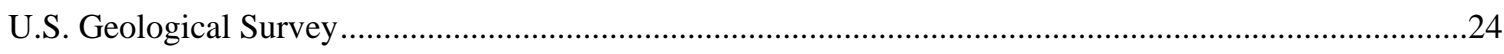

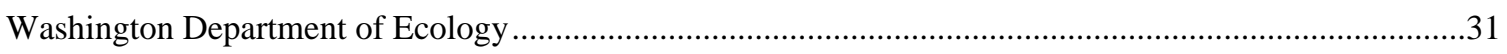

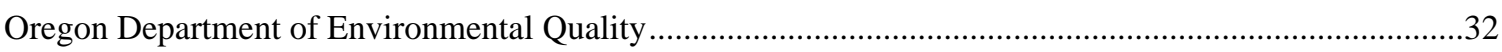

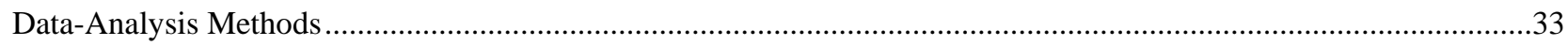

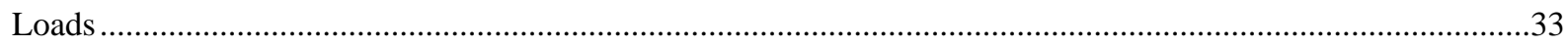

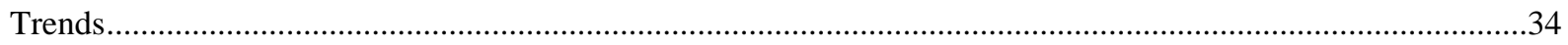

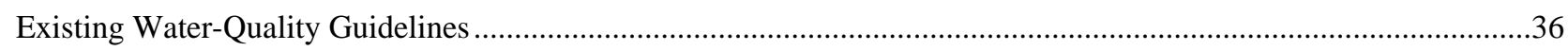

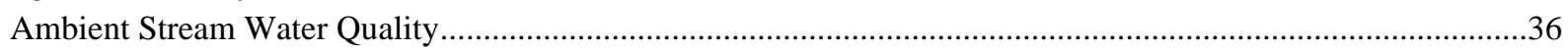

Aquatic Life .

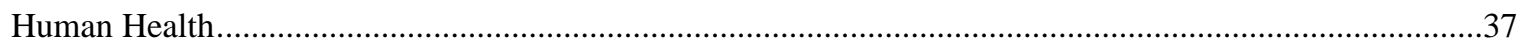

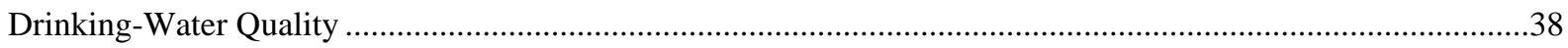

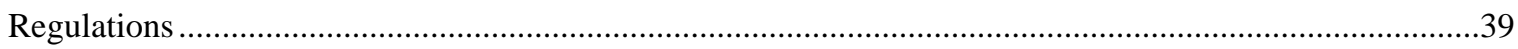

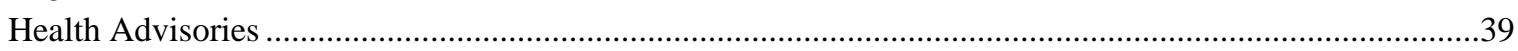

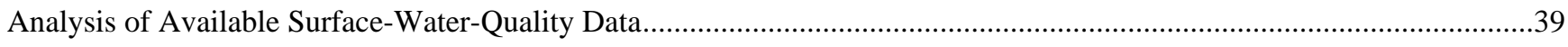

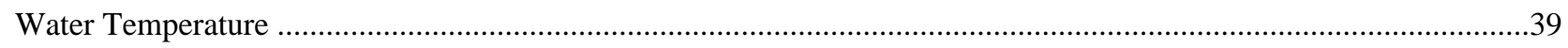

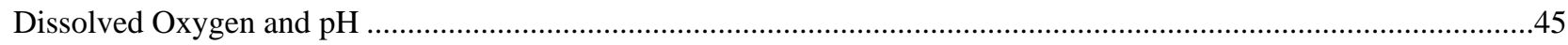

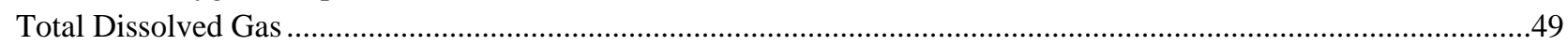

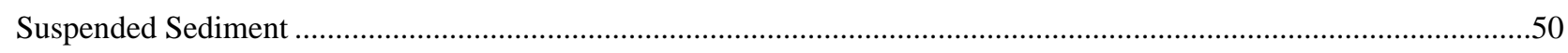

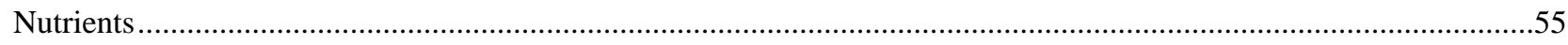

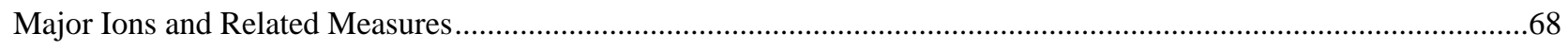

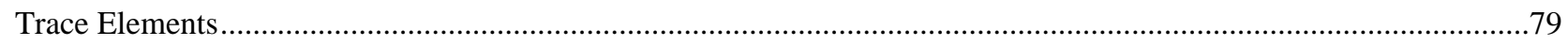

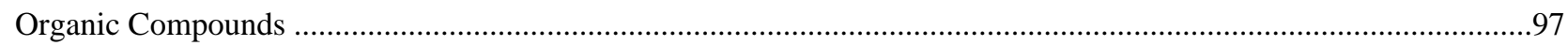

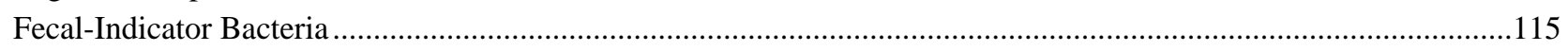

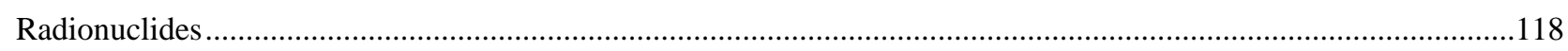

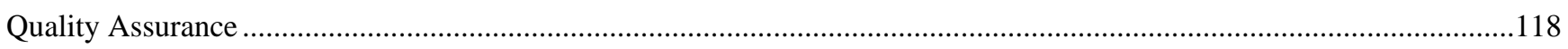

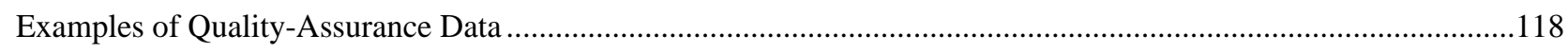

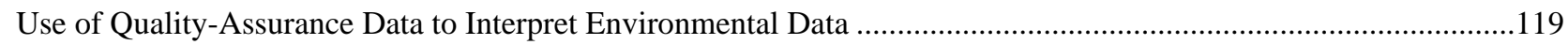

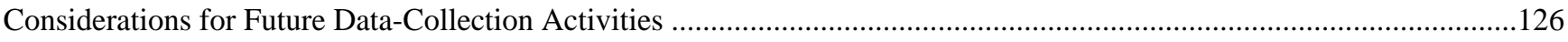

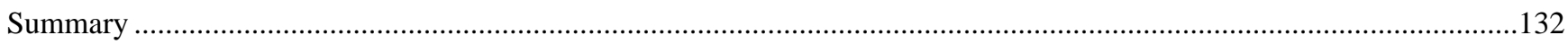

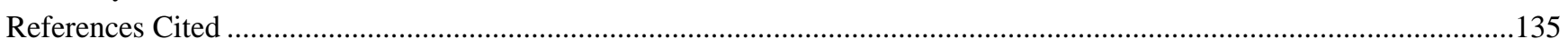

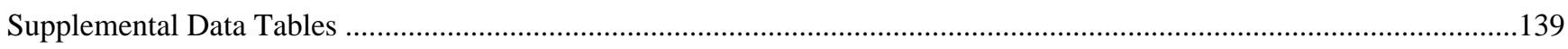




\section{FIGURES}

1.- 2. Maps showing:

1. The Columbia River Basin 3

2. The lower Columbia River Basin, Oregon and Washington .......................................................................

3. -37 . Graphs showing:

3. Annual and mean annual precipitation at Bonneville Dam, Government Camp, Portland, Eugene,

Cougar, and Astoria, lower Columbia River Basin, Oregon and Washington, 1920-93

4. Mean monthly precipitation at Portland, Cougar, and Eugene, lower Columbia River Basin, Oregon and Washington

5. Estimated monthly mean streamflow in the Columbia River at mouth near Astoria for the low-, median-, and high-streamflow years, lower Columbia River Basin, Oregon ....................................................11

6. Annual mean streamflow and median annual streamflow for the Columbia River at mouth, 1928-84 .............11

7. Estimated monthly mean streamflow in the Columbia River at mouth near Astoria, 1967 water year, and Columbia River at Beaver Army Terminal near Quincy, 1994 water year, lower Columbia River Basin, Oregon and Washington

8. Streamflows in the Willamette River at Portland and Columbia River at Warrendale, lower Columbia River Basin, Oregon and Washington, 1994.

9. -12. Maps showing:

9. Land use and land cover by hydrologic units, lower Columbia River Basin, Oregon and Washington, 1980 ...16

10. Point-source domestic discharges, lower Columbia River Basin, Oregon and Washington, 1994 ...................18

11. Locations of point sources other than domestic discharge, lower Columbia River Basin, Oregon and Washington, 1994

12. Point-source discharges for chemical, seafood processing, and other miscellaneous facilities, lower Columbia River Basin, Oregon and Washington, 1994.

13. Graph showing number of historical surface-water-quality determinations by constituent group, lower

Columbia River Basin, Oregon and Washington, 1939-93

14. Map showing U.S. Geological Survey sampling locations, lower Columbia River Basin, Oregon and Washington, 1994.

15.-24. Graphs showing:

15. Distribution of daily mean water temperatures in the lower Columbia River Basin, Oregon and Washington, 1968-94 water years.....

16. Distribution of daily mean water temperatures in the Columbia River at Warrendale, Kalama, and Bradwood and in the Willamette River at Portland, lower Columbia River Basin, Oregon and Washington, 1975-92

17. Instantaneous water temperatures in the main stem and tributaries of the lower Columbia River Basin, Oregon and Washington, July to September 1994.

18. Distribution of dissolved-oxygen concentrations, lower Columbia River Basin, Oregon and Washington, 1994

19. Distribution of 1974-94 and 1994 dissolved-oxygen concentrations measured in the Columbia River at Warrendale, lower Columbia River Basin, Oregon ....

20. Distribution of 1949-58, 1972-94, and 1994 dissolved-oxygen concentrations measured in the Willamette River at Portland, lower Columbia River Basin, Oregon.

21. Distribution of 1960-74 and 1994 dissolved-oxygen concentrations measured in the Kalama River above Spencer Creek near Kalama, lower Columbia River Basin, Washington

22. (a) $\mathrm{pH}$ in the main stem and tributaries of the lower Columbia River Basin and

(b) chlorophyll- $a$ concentrations in relation to $\mathrm{pH}$ in the Columbia River at river mile 102,

downstream from Hayden Island, Oregon and Washington, 1994

23. Total dissolved-gas concentrations in the Columbia River at Warrendale, lower Columbia River Basin, Oregon, 1984-93 and 1994

24. Relation between daily mean streamflow and suspended-sediment concentrations in the Willamette River at Portland and Columbia River at Warrendale, lower Columbia River Basin, Oregon, 1994

25. Maps showing spatial distribution of 90th-percentile values for phosphorus concentrations in unfiltered water and nitrite plus nitrate and ammonia in filtered water by subbasin or unit, lower Columbia River Basin, Oregon and Washington, 1964-93. 
26.-27. Graphs showing:

26. Concentrations of phosphorus in unfiltered water and nitrite plus nitrate in filtered water in the Columbia River at Hayden Island, Willamette River at Portland, and Columbia River near Columbia City, lower Columbia River Basin, Oregon and Washington, 1994

27. Monthly mean daily loads of ammonia and nitrite plus nitrate in filtered water and phosphorus in unfiltered water in the Columbia River at Warrendale, Willamette River at Portland, and Columbia

River at Beaver Army Terminal, lower Columbia River Basin, Oregon and Washington, 1994

28. Map showing spatial distribution of 90th-percentile values for total dissolved solids by subbasin or unit, lower Columbia River Basin, Oregon and Washington, 1947-93...

29.-37. Graphs showing:

29. Major-ion composition in the Columbia River at Warrendale, Willamette River at Portland, and Columbia River at Beaver Army Terminal, lower Columbia River Basin, Oregon and Washington, 1994.

30. Specific conductance in the main stem and tributaries during August and November, lower Columbia River Basin, Oregon and Washington, 1994.

31. Major-ion composition in the Columbia River near Columbia City, Willamette River at Portland, and Multnomah Channel near mouth at St. Helens, lower Columbia River Basin, Oregon, 1994

32. Concentrations of silica in the Willamette River at Portland, Multnomah Channel near mouth at St. Helens, and Columbia River near Columbia City, lower Columbia River Basin, Oregon, 1994 ..................79

33. Frequently detected organic compounds, lower Columbia River Basin, Oregon and Washington, 1994.........105

34. Frequency of detection for selected organic compounds in the lower Columbia River Basin, Oregon and Washington, 1994.

35. Relation between daily mean streamflow and atrazine concentrations in filtered water in the Willamette River at Portland, lower Columbia River Basin, Oregon, 1994.

36. Atrazine concentrations in filtered water from November to December and from August to September, lower Columbia River Basin, Oregon and Washington, 1994

37. Distribution of fecal-coliform bacteria concentrations in the Columbia River at Warrendale and Willamette River at Portland, Oregon, 1976-94.

\section{TABLES}

1. Summary statistics for seasonal variations in streamflow at selected sites, lower Columbia River Basin, Oregon and Washington, 1967 water year.

2. Percentage of land in specific land-use and land-cover categories, lower Columbia River Basin, Oregon and Washington, 1980

3. Water use in the lower Columbia River Basin, Oregon and Washington, 1990 water year

4. Inventory of point-source classifications, lower Columbia River Basin, Oregon and Washington

5. Hydrologic units included in historical data retrievals and subbasin units used for analysis of historical data, lower Columbia River Basin, Oregon and Washington.....

6. Sites that have the most water-quality determinations from 1939-93, lower Columbia River Basin, Oregon and Washington..

7. Sampling sites and constituents analyzed, lower Columbia River Basin, Oregon and Washington, 1994 ................25

8. Method reporting limits for major ions, nutrients, organic carbon, and trace elements analyzed in filtered and unfiltered water, lower Columbia River Basin, Oregon and Washington, 1994.....

9. Method detection limits for organic compounds analyzed in filtered water, lower Columbia River Basin, Oregon and Washington, 1994.

10. Method reporting limits for trace elements analyzed in suspended sediment, lower Columbia River Basin, Oregon and Washington, 1994.

11. Laboratory analytical methods and reporting limits for Washington Department of Ecology, lower Columbia River Basin, 1994

12. Amount of water quality data available for load estimation program, and mean 95-percent confidence intervals for load estimates at three sites in the lower Columbia River Basin, Oregon and Washington.

13. Water-quality sites that have continuous record of stream temperature, lower Columbia River Basin, Oregon and Washington, 1968-94. 
14. Monthly distributions of daily mean water temperatures at selected sites, lower Columbia River Basin, Oregon and Washington, 1969-92.

15. Signs of gas-bubble trauma in salmonids.

16. Distribution of suspended-sediment and suspended-solids concentrations, lower Columbia River Basin, Oregon and Washington, 1994.

17. Calculated monthly and annual mean daily loads for suspended sediment at selected sites, lower Columbia River Basin, Oregon, 1994

18. Calculated monthly and annual mean daily suspended-sediment loads for the current water year and low-, median-, and high-streamflow water years in the Columbia River at Warrendale and Willamette River at Portland, lower Columbia River Basin, Oregon.

19. Comparison of nutrient concentrations in water in the lower Columbia River Basin to surface waters of the United States...

20. Distribution of nutrient concentrations in water, lower Columbia River Basin, Oregon and Washington, 1994

21. Calculated monthly and annual mean daily nutrient loads for the current water year and low-, median-, and high-streamflow water years in the Columbia River at Warrendale and Willamette River at Portland, lower Columbia River Basin, Oregon .

22. Calculated monthly and annual mean daily loads for ammonia and nitrite plus nitrate in filtered water and phosphorus in unfiltered water at selected sites, lower Columbia River Basin, Oregon, 1994 .....

23. Mass balances for streamflow and ammonia and nitrite-plus-nitrate loads in filtered water, lower

Columbia River Basin, Oregon and Washington, 1994

24. Mass balances for streamflow, phosphorus loads in unfiltered water, and suspended-sediment loads, lower Columbia River Basin, Oregon and Washington, 1994.

25. Distribution of major-ion concentrations in filtered and unfiltered water, lower Columbia River Basin, Oregon and Washington, 1994.

26. Calculated monthly and annual mean daily loads for total dissolved solids at selected sites, lower Columbia River Basin, Oregon, 1994

27. Comparison of selected major- and trace-element concentrations in filtered water in the lower Columbia River Basin to surface waters worldwide.

28. Distribution of major- and trace-element concentrations in filtered water, lower Columbia River Basin, Oregon and Washington, 1994.

29. Frequency of detection of selected major and trace elements in filtered water, lower Columbia River

Basin, Oregon and Washington, 1994.

30. Instantaneous loads for major and trace elements for selected low and high streamflow conditions in the Columbia River at Warrendale, Willamette River at Portland, and Columbia River at Beaver Army Terminal, lower Columbia River Basin, Oregon, 1994

31. Distribution of major- and trace-element concentrations in suspended sediment, lower Columbia River Basin, Oregon and Washington, 1994.

32. Mass balances for streamflow, suspended zinc loads, and suspended aluminum loads, lower Columbia River Basin, Oregon and Washington, August through September, 1994

33. Number of historical determinations and uncensored data values for organic compounds, lower Columbia River Basin, Oregon and Washington, 1965-93......

34. Concentrations of organic compounds detected in filtered water, lower Columbia River Basin, Oregon and Washington, 1994 ...

35. Chemical classifications for organic compounds analyzed, lower Columbia River Basin, Oregon and Washington, 1994.

36. Distribution of organic-compound concentrations in filtered water, lower Columbia River Basin, Oregon and Washington, 1994.

37. Indicator-bacteria standards and concentrations of concern for Oregon and Washington streams, lower Columbia River Basin, 1994

38. Distribution of fecal-indicator bacteria concentrations, lower Columbia River Basin, 1994 ..............................117

39. Quality-assurance data for field measurements, lower Columbia River Basin, Oregon, 1994...............................120

40. Quality-assurance data for major ions, lower Columbia River Basin, Oregon, 1994 ...........................................121

41. Quality-assurance data for nutrients, lower Columbia River Basin, Oregon, 1994. 
42. Quality-assurance data for fecal-indicator bacteria, chlorophyll $a$, suspended sediment, suspended solids, and organic carbon, lower Columbia River Basin, Oregon, 1994

43. Quality-assurance data for filtered-water trace elements, lower Columbia River Basin, Oregon, 1994.

44. Quality-assurance data for suspended trace element samples, lower Columbia River Basin, Oregon, 1994

45. Quality-assurance data for organic compounds in filtered water, lower Columbia River Basin, Oregon and Washington, 1994

46. Point-source locations and National Pollutant Discharge Elimination System permit levels of effluent discharge, lower Columbia River Basin, Oregon and Washington, 1994.

47. Summary of trace-element concentrations that exceed screening values derived from water-quality guidelines, lower Columbia River Basin, Oregon and Washington, 1994

48. Summary of physical and microbiological measurements that exceed screening values derived from ambient water-quality criteria, lower Columbia River Basin, Oregon and Washington, 1994

49. Summary of constituent concentrations in filtered water that did not exceed screening values derived from water-quality guidelines, lower Columbia River Basin, Oregon and Washington, 1994 .....

50. Summary of trends in selected water-quality constituent, lower Columbia River Basin, Oregon, 1973-95 .157

\section{CONVERSION FACTORS}

[SI = International System of units, a modernized metric system of measurement]

Factors for converting SI metric units to inch/pound units

\begin{tabular}{|c|c|c|}
\hline Multiply & By & To obtain \\
\hline \multicolumn{3}{|c|}{ Length } \\
\hline micrometer $(\mu \mathrm{m})$ & 0.00003937 & inch (in) \\
\hline millimeter (mm) & 0.03937 & inch \\
\hline meter $(\mathrm{m})$ & 3.281 & foot $(\mathrm{ft})$ \\
\hline \multicolumn{3}{|c|}{ Volume } \\
\hline milliliter (mL) & 0.001057 & quart (qt) \\
\hline liter $(\mathrm{L})$ & 1.057 & quart \\
\hline liter & 0.2642 & gallon (gal) \\
\hline \multicolumn{3}{|c|}{ Mass } \\
\hline nanogram (ng) & 0.00000000003527 & ounce (oz avoirdupois) \\
\hline microgram (mg) & 0.00000003527 & ounce \\
\hline milligram (mg) & 0.00003527 & ounce \\
\hline $\operatorname{gram}(\mathrm{g})$ & 0.03527 & ounce \\
\hline kilogram (kg) & 35.27 & ounce \\
\hline \multicolumn{3}{|c|}{ Density } \\
\hline grams per cubic centimeter $\left(\mathrm{g} / \mathrm{cm}^{3}\right)$ & 0.5780 & ounces per cubic inch $\left(\mathrm{oz} / \mathrm{in}^{3}\right)$ \\
\hline \multicolumn{3}{|c|}{ Temperature } \\
\hline degrees Celsius $\left({ }^{\circ} \mathrm{C}\right)$ & $\left({ }^{1}\right)$ & degrees Fahrenheit $\left({ }^{\circ} \mathrm{F}\right)$ \\
\hline \multicolumn{3}{|c|}{ Concentration, in water } \\
\hline nanograms per liter (ng/L) & 1 & parts per trillion (ppt) \\
\hline micrograms per liter $(\mu \mathrm{g} / \mathrm{L})$ & 1 & parts per billion (ppb) \\
\hline milligrams per liter $(\mathrm{mg} / \mathrm{L})$ & 1 & parts per million (ppm) \\
\hline \multicolumn{3}{|c|}{ Concentration, in sediment } \\
\hline micrograms per gram $(\mu \mathrm{g} / \mathrm{g})$ & 1 & parts per million (ppm) \\
\hline
\end{tabular}

\footnotetext{
${ }^{1}$ Temperature ${ }^{\circ} \mathrm{F}=1.8\left(\right.$ Temperature $\left.{ }^{\circ} \mathrm{C}\right)+32$
} 


\section{Water Quality of the Lower Columbia River Basin: Analysis of Current and Historical Water-Quality Data through 1994}

By Gregory J. Fuhrer, Dwight Q. Tanner, Jennifer L. Morace, Stuart W. McKenzie, and Kenneth A. Skach

\section{Abstract}

The lower Columbia River Basin includes the river basins draining into the Columbia River below Bonneville Dam-the largest of which is the Willamette River. This report presents the results of a study by the U.S. Geological Survey, done in cooperation with the Lower Columbia River Bi-State WaterQuality Program, to describe the water-quality conditions in the lower Columbia River Basin by interpreting historical data collected and data collected in 1994. Historical waterquality data spanning more than 50 years and comprising more than 200 parameters were collated for interpretation in this report. The U.S. Geological Survey, the Oregon Department of Environmental Quality, and the Washington Department of Ecology collected water-quality data at 10 sites in the lower Columbia River Basin from January to December of 1994. Water-quality constituents measured in 1994 were screened against U.S. Environmental Protection Agency (EPA) and State guidelines.

Arsenic, a human carcinogen, was detected in 15 of 16 samples in the lower Columbia River, but was not detected in any of the sampled tributaries. All 15 arsenic detections had concentrations that exceeded both the EPA ambient water-quality criteria for the protection of human health and the EPA human-health advisories for drinking water. Chromium was detected at all four Columbia River sites-most frequently in the
Columbia River at Hayden Island. None of the chromium concentrations detected, however, exceeded water-quality criteria or guidelines.

Measurements of suspended traceelement concentrations (trace-element concentrations associated with the suspendedsediment fraction) showed that the suspended form is the dominant transport phase for aluminum, iron, and manganese, whereas the dissolved form is the dominant transport phase for arsenic, barium, chromium, and copper. On the basis of tributary loads during summer low-flow months, sources of suspended silver, nickel, aluminum, and antimony exist in the lower Columbia River Basin, whereas the sources of suspended zinc and arsenic exist outside of the lower basin.

Twenty organic compounds were detected of the 47 compounds analyzed for this study. None of the organic compounds measured exceeded EPA's ambient water-quality criteria or drinking-water guidelines. The Willamette River at Portland had the largest number of detections, and all 20 compounds were detected at one time or another at that site. The largest concentrations of the agricultural pesticides, atrazine, metolachlor, and simazine were detected in the Willamette River, where they were detected in 93,86, 93 percent, respectively, of the samples collected. The highest concentrations of atrazine in the Willamette River were associated with the spring application and fall runoff periods. 
Both historical and current data showed that the highest water temperatures in the lower Columbia River Basin are present during August. For water years 1977-81 in the Columbia River at Bradwood (river mile 38.9), 75 percent of the daily mean water temperatures during August exceeded 20 degrees Celsius, a "special condition" criterion for the State of Washington. The special condition criterion was exceeded at four sites on the lower Columbia River during July and August, 1994-a period coinciding with season-high air temperatures and low streamflow. Trend tests using data from 1974 to 1994 showed significant $(\rho<0.05)$ upward trends for water temperature at the Columbia River at Warrendale and the Willamette River at Portland.

Concentrations of dissolved oxygen and total dissolved gas were above saturation levels during high stormflows in the lower Columbia River and the Willamette River during 1994. The high concentrations of total dissolved gas in the Columbia River exceeded Oregon and Washington State standards of 110 percent of saturation and were caused by spilling water at the Columbia River dams. Aquatic life in the lower Columbia River Basin was not subjected to low dissolved-oxygen concentrations.

Comparison of dissolved-oxygen concentrations in the Willamette River from 1949-58 to 1972-94 showed a significant increase in dissolved-oxygen concentrations during the low-streamflow months of summer.

Trend tests showed significant $(\rho<0.05)$ downward trends from 1973 to 1994 for three constituents at the Columbia River at Warrendale: phosphorus in unfiltered water, total dissolved solids, and specific conductance. These trends may be a consequence of more conservative agricultural practices in the area upstream from Warrendale.

\section{INTRODUCTION}

The Columbia River Basin (fig. 1), molded and sculpted through geologic time, has become a dominant landscape feature in the Pacific Northwest. It has witnessed the birth of new mountains, the slow weathering of old ones, the violent eruptions of volcanoes, and some of the most cataclysmic floods in Earth's history. The basin has been home to Native American peoples for thousands of years and has attracted explorers and settlers from many countries. The Columbia River drains parts of the States of Washington, Idaho, Montana, Wyoming, Nevada, Utah, and Oregon, and the Province of British Columbia, where its headwaters arise. It flows more than 1,200 miles from Columbia Lake to its mouth at the Pacific Ocean. The Columbia River has been both habitat and passageway for salmon and other aquatic life, and has had spiritual and physical significance to Native Americans for centuries. As people industrialized the Pacific Northwest, water use within the basin changed dramatically: hydroelectric projects were completed to provide electricity, navigation channels were constructed to promote commerce, diversion dams were constructed to increase agricultural production through irrigation, reservoirs were constructed to reduce flooding and to provide recreational opportunities, and cities grew along the banks of the basin's rivers.

Development within the Columbia River Basin has not been without side effects. When Captain Robert Gray discovered the Columbia River in 1792, an estimated 10 to 16 million adult salmon were returning annually to the river; this salmon resource was once considered to be unlimited. Between 1985 and 1990 , however, only 1.1 to 2.8 million adults returned each year. Not only has the total number of salmon declined drastically, but the average size of returning adults is markedly smaller for several stocks. An estimated 67 individual stocks have been permanently eliminated, 4 stocks are presently listed as threatened or endangered under the Endangered Species Act, and an additional 72 stocks are thought to be in jeopardy.

Concern about degradation of water quality in the Columbia River Basin began in the late 1800's (P. Klingeman, Oregon State University, written commun., 1995). Hydropower development, irrigated agriculture, logging, mining, stream channelization, and urbanization are recognized as contributing factors. Hydroelectric and agricultural development have changed the quantity and timing of seasonal runoff, modifying water temperatures 


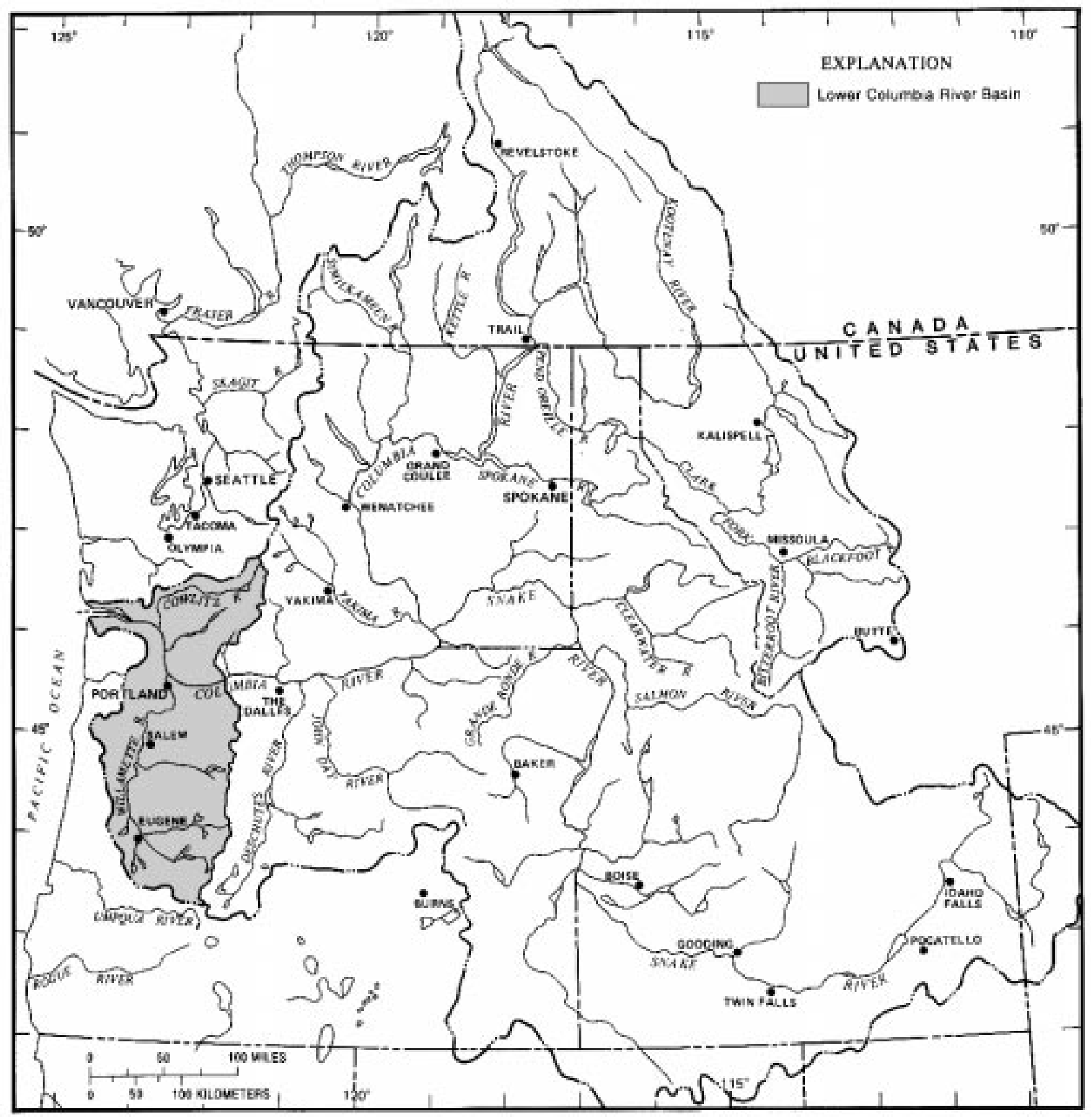

Figure 1. The Columbia River Basin. 
and sometimes supersaturating the river water with air, which can cause gas-bubble trauma in fish. Dissolved-oxygen levels, while adequate in the Columbia River, have been depressed in some tributaries by municipal and industrial wastes. The Snake and Willamette Rivers are known to be the major contributors of nitrogen and phosphorus to the Columbia River. Suspended sediment tends to increase in subbasins influenced by logging and agriculture. Toxic chemicals, such as pesticides, polychlorinated biphenyls (PCB), and trace elements, have been found in fish of the Columbia River Basin, resulting in at least one recent human health advisory (Stober and Nakatani, 1992). Radioactivity in the lower Columbia River has historically been of concern, a result of Hanford's eight plutonium production reactors which, one by one, have been closed (Toombs and others, 1983). Additionally, radionuclides have historically been of concern. Unquestionably, today's water managers face a difficult and complex task as they strive to maintain a healthy environment in the basin, while maintaining the livelihood of the people who live in it.

\section{Background}

The Lower Columbia River Bi-State WaterQuality Program was initiated in 1990 by the Governors of Oregon and Washington. On the basis of workshops and public comments, the Governors concluded that the study of the lower Columbia River Basin would receive broader support in a $\mathrm{Bi}$ State study framework than as part of the Federal Government's National Estuary Program. The BiState study is a 4-year program that is sponsored jointly by the Washington Department of Ecology (WDOE), the Oregon Department of Environmental Quality (ODEQ), the Washington and Oregon Public Port Associations, and the Northwest Pulp and Paper Association. A Bi-State steering committee was created to assist WDOE and ODEQ in administering this program, which will study water quality below Bonneville Dam (river mile [RM] 146.1). The committee is composed of representatives from local governments, industries, Native American Tribes, fishing groups, environmental groups, the general public, public ports, and Federal agencies. On the basis of the water-quality information obtained, the steering committee will evaluate options and provide recommendations for improving and protecting water quality and beneficial uses in the Columbia River. ODEQ and WDOE will also be reviewing data and making their own determinations, in addition to responding to recommendations made by the steering committee.

The Bi-State steering committee identified several major goals for the water-quality program in the lower Columbia River. The goals are as follows:

\section{Provide a regionally consistent description of water-quality conditions;}

2. Define seasonal and long-term trends (or lack of trends) in water quality; and

3. Identify, describe, and explain, as possible, the major factors that affect observed water-quality conditions and trends.

Within the framework of the Bi-State study, numerous preliminary tasks have been completed to assess water quality in the lower Columbia River (Tetra Tech, Inc., 1993). Preliminary tasks included establishing a library database for isolating data gaps and identifying problem areas. Because waterquality data were sparse, however, the entire lower Columbia River was considered a data gap in 1990. Also important was an inventory of pollutant sources, which included point sources, nonpoint sources (dispersed water-based activities or dispersed land-based activities), and in-place sources (landfill leachate). On the basis of available data, pollutant-loading estimates were made for point sources and were used to identify appropriate analytical suites as well as to aid in the selection of sampling sites for a reconnaissance study. A literature review of physical and hydrologic characteristics of the lower Columbia River was conducted to assist in determining the potential environmental fate of pollutants. Biological indicator species were selected on the basis of existing data for major habitats and biological communities, and from biological exposure (bioaccumulation) and response (community structure) studies. To determine areas that are especially sensitive to pollutants, river miles of the lower Columbia River were characterized according to the various beneficial uses of rivers, such as water supply, recreation, or fish and wildlife.

The lower Columbia River reconnaissance sampling was conducted from September through November 1991 (Tetra Tech, Inc., 1993). Water 
samples were collected from 45 sites in the lower Columbia River and analyzed for trace elements, nutrients, and other parameters. Nutrient concentrations were not quantified because analytical-method reporting limits for nutrients were higher than the nutrient concentrations in the samples. Aluminum, barium, iron, and lead were the only trace elements that were frequently detected. Analytical-method reporting limits for several trace elements, including lead, mercury, nickel, selenium, and silver, were greater than the U.S. Environmental Protection Agency's (EPA) ambient water-quality criteria, thus hampering identification of trace elements of concern (U.S. Environmental Protection Agency, 1986a). Organic constituents were measured at five sites; in general, semivolatile and volatile organic compounds, pesticides, and PCBs were not detected, with the exception of bis(2ethylhexyl)phthalate, a common laboratory contaminant. The investigators noted that some of the target organic compounds may have been present at concentrations that were undetectable using the conventional methods employed for the reconnaissance study. Bulk sediment samples were collected at 54 sites in the lower Columbia River and analyzed for trace elements, organic compounds, dioxins and furans, and other miscellaneous parameters. Fish-tissue samples were collected at 18 sites and analyzed for trace elements and organic compounds. Benthic community structure was assessed at 54 sites. All organisms removed from the streambed sediment were enumerated and identified to the lowest practical taxonomic level, generally genus or species.

Supplemental reconnaissance measurements in backwater areas of the Columbia River were made in 1993 (Tetra Tech, Inc., 1994). Backwater areas are hydrologically low-energy areas that promote the settling of fine-grained sediment and associated contaminants. Water samples from 15 backwater sites were analyzed for trace elements, nutrients, bacteria, and other parameters. Water temperatures at several backwater sites exceeded Washington State's temperature standard of $20^{\circ} \mathrm{C}$ (degrees Celsius). In backwater environments, concentrations of nitrogen and phosphorus approached concentrations that, under proper conditions of light and temperature, have caused nuisance algal blooms in lake environments. Investigators noted that concentrations of aluminum, iron, copper, and lead from unfiltered samples frequently exceeded EPA's ambient waterquality criteria for chronic toxicity to aquatic life. Investigators also concluded that exceedances were principally by trace elements associated with the suspended-sediment fraction. Streambed sediments from the 15 backwater sites also were sampled concurrently for trace elements and organic compounds. On the basis of normalization techniques, some trace elements, such as arsenic in backwater areas and copper in the main stem, may have anthropogenic sources. Pesticides were detected infrequently; the infrequent detection was attributed to the diffuse nature of pesticide inputs from agricultural sources and the lack of local nearshore sources. Polyaromatic hydrocarbons, however, were detected in the vicinity of urban and industrial sources.

\section{Purpose and Scope}

Historically, water-quality studies in the lower Columbia River have focused on specific river reaches; many of these studies lack the continuity necessary to assess water quality in a river-basin framework. The Bi-State study has addressed this data gap by initiating an ambient-monitoring program that will assess temporal variations in constituent concentrations and loads in 1994.

The purpose of this report is to describe the water-quality conditions in the lower Columbia River and major tributaries to the extent possible, by:

(1) Examining seasonal variations in concentrations of water-quality constituents in water (filtered and unfiltered) and suspended sediment;

(2) Portraying spatial variations in historical waterquality data;

(3) Determining trends in concentrations of waterquality constituents in water (filtered and unfiltered) and in physical water-quality measurements (for example, water temperature) for sites with adequate historical data;

(4) Analyzing the suitability of surface water for maintenance of aquatic life and protection of human health;

(5) Determining instream loads for selected waterquality constituents and comparing instream loads in major subbasins to instream loads in the Columbia River; and 
(6) Listing point sources and, to the extent possible, the associated discharges.

\section{Acknowledgments}

The authors wish to acknowledge the aid and advice provided by the members of the Bi-State Steering Committee. The committee included:

Ralph Ennis
Nelson Graham
Mike Lindberg
Al Whitford
Llewellyn Matthews
Rollie Montagne
Glenn Vanselow
Steve Wille
Elmer Scott, Jr.
Wilbur Slockish, Jr.
Cyndy deBruler
Jean R. Cameron

Salmon For All Longview City Manager Portland City Commissioner Longview Fibre Company

Northwest Pulp and Paper Association

Port of Portland Pacific Northwest Waterways Association

Southwest Washington Anglers

Warm Springs Reservation

Native American Tribes

Columbia River United

Oregon Environmental Council

Carol Schuler

Jeremy Buck

Jim Bergeron

Carol Carver

Stuart McKenzie

R. Ted Bottiger

Joyce Cohen

Andy Schaedel

Don Yon

Bill Young

David Peeler

Brian Offord

Helen Bresler
John Gabrielson

U.S. Environmental

Protection Agency

Special thanks to: (1) Willamette Basin National Water-Quality Assessment (NAWQA) Program and Willamette State Study (both USGS projects) for sharing some of the sampling and laboratory efforts; (2) Doug Cushman (USGS) for data collection; (3) Matt Johnston (USGS) for performing solid-phase extractions, organic-carbon filtrations, and centrifugation; (4) Don Anderson (USGS) for centrifuging efforts; (5) Larry Scharnberg (USGS) for performing the chlorophyll determinations; (6) Carol Lewis (USGS, Reston, Virginia) for performing the data retrieval from EPA's database; (7) Doug Terra (ODEQ) for providing Tetra Tech, Inc. data from the 1991 study; (8) Bill Ehinger (WDOE) and Greg Pettit (ODEQ) for collecting water-quality data in 1994; (9) Debra Nesbit (ODEQ), Holly Francis, Cindy James, and Tim Hilliard (all of WDOE) for their assistance in obtaining and clarifying point-source data; and (10) Karl Lee (USGS) for streamflow calculations.

\section{THE LOWER COLUMBIA RIVER BASIN}

The Columbia River drains an area of 259,000 square miles and is ranked seventh in length and fourth in streamflow among United States rivers (U.S. Geological Survey, 1981; Saboe, 1991). It flows 1,243 miles from its headwaters in the Canadian Rockies of British Columbia, across the State of Washington, and along the border of Washington and Oregon to its mouth at the Pacific Ocean (fig. 1). There are 11 dams on the Columbia River's main stem in the United States and 162 dams that form reservoirs with capacities greater than 5,000 acre-feet in the United States and Canadian parts of the basin. The northern and eastern sections of the Columbia River Basin contain mainly sedimentary and metamorphic rocks, whereas the southern, western, and central parts contain mainly igneous rocks.

The lower Columbia River Basin, the subject of this report, drains the area from Bonneville Dam to the mouth of the Columbia River (fig. 2). In the lower basin, the Columbia River flows 146.1 miles and drains an area of about 18,000 square miles, all to the west of the crest of the Cascade Range. The major tributaries and associated drainage areas in the lower Columbia River Basin, in downstream order, are the Sandy River (500 square miles), the 


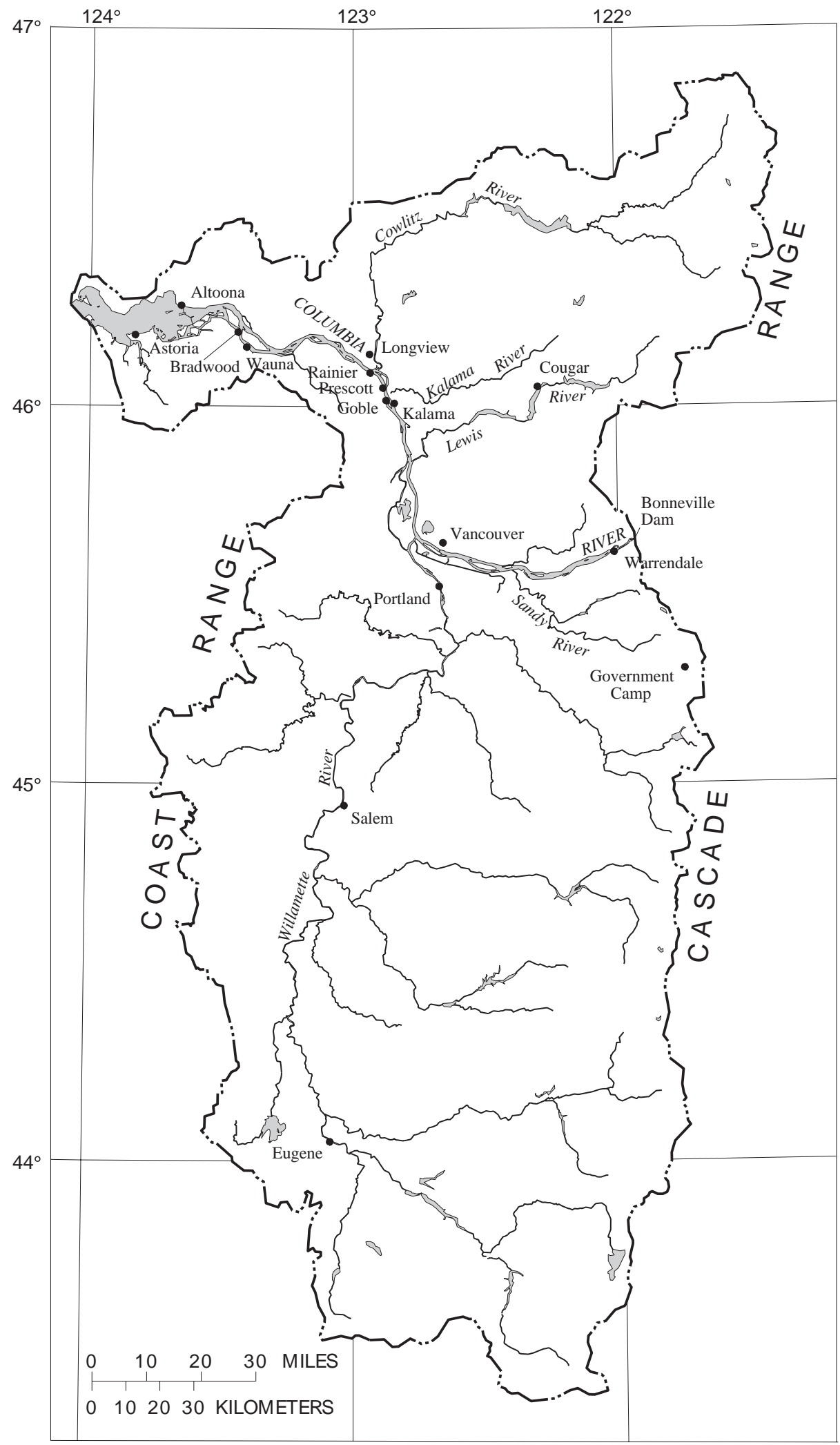

Base from U.S. Geological Survey, 1:100,000, 1986

Universal Transverse Mercator zone 10

Figure 2. The lower Columbia River Basin, Oregon and Washington. 
Willamette River (11,400 square miles), the Lewis River (1,000 square miles), the Kalama River (200 square miles), and the Cowlitz River (2,500 square miles).

\section{Precipitation}

Precipitation varies considerably across the lower Columbia River Basin but generally exceeds that in the rest of the Columbia River Basin. The Cascade Range creates a rain shadow which is responsible for the greater quantities of precipitation in the lower Columbia River Basin. Historically, mean annual precipitation in the lower Columbia River Basin ranged from 113 inches at Cougar, Washington, to about 37 inches at Portland, Oregon (fig. 3) and was generally higher in the mountains (Cougar and Government Camp) and on the coast (Astoria) than in the valleys (Portland and Eugene). Intrasite variations in annual precipitation can be large depending on meteorological conditions. For example, annual precipitation at Cougar ranged from as little as 78.27 inches in 1952 to as much as 141.84 inches in 1983 (Earth-Info, Inc., 1993). The annual precipitation at Portland for the 1994 water year (WY) was 36.32 inches (Oregon Climate Service, 1994), which is similar to the mean annual precipitation.

Most of the precipitation in the lower Columbia River Basin falls from November through March. The mean monthly precipitation during this period, in Portland, Eugene, and Cougar was 66, 70, and 71 percent, respectively, of the mean annual precipitation (fig. 4).

\section{Streamflow Conditions}

The Willamette River is the major tributary of the lower Columbia River. It drains 65 percent of the area within the lower Columbia River Basin. On the basis of mean annual streamflow for the period 1928-65 (Orem, 1968), the Willamette River's discharge represented 17 percent of the streamflow in the Columbia River at Vancouver, Washington, which is located 0.5 miles upstream from the confluence of the Willamette and Columbia Rivers. For those same years, the Willamette River's contribution to the Columbia River's total streamflow at its mouth near Astoria, Oregon, averaged 13 percent. Compared with other lower
Basin tributaries during the period 1928-65, the Willamette River streamflow represented 58 percent of the increase in Columbia River streamflow between Vancouver and the mouth.

Streamflow in the main stem of the lower Columbia River is affected by spring snowmelt, winter rainstorms, and regulation by many dams. In addition to the dams on the main stem of the Columbia River and the many other dams on tributaries above Bonneville Dam, there are 17 reservoirs in the Willamette River Basin, 3 reservoirs in the Lewis River Basin, and 2 reservoirs in the Cowlitz River Basin. Daily flood-control regulation is generally required during the spring snowmelt season. Outflows and forebay levels at Grand Coulee Dam are specified by the U.S. Army Corps of Engineers between May and June in order to provide storage capacity to dampen peak flows. During the 1993 WY, for example, the regulated peak flow at The Dalles during the snowmelt season was $382,000 \mathrm{ft}^{3} / \mathrm{s}$ (cubic feet per second), while the unregulated peak flow would have been $602,000 \mathrm{ft}^{3} / \mathrm{s}$. Local flooding in the lower Columbia River begins when streamflow reaches about 450,000 $\mathrm{ft}^{3} / \mathrm{s}$ (Columbia River Water Management Group, 1994).

In the Willamette River Basin, reservoirs are operated by the U.S. Army Corps of Engineers. They reach minimum flood-control elevations between November 1 and 15 in reservoirs not generating power and by November 30 in reservoirs generating power. Much of the runoff during February and March is due to rainfall. At the higher elevations, however, precipitation occurs as snow, and runoff is often delayed until the spring snowmelt. During floods, water is held in reservoirs until downstream discharges from unregulated streams have subsided and then released at a rate that does not exceed established flood-regulation goals. The well-defined limits of the flood season allow winter storm runoff and spring snowmelt runoff to be impounded and subsequently released during low water conditions in summer and early fall (U.S. Army Corps of Engineers, 1989). Releases during summer and fall are made to satisfy requirements for fisheries, irrigation, navigation, and pollution abatement. 

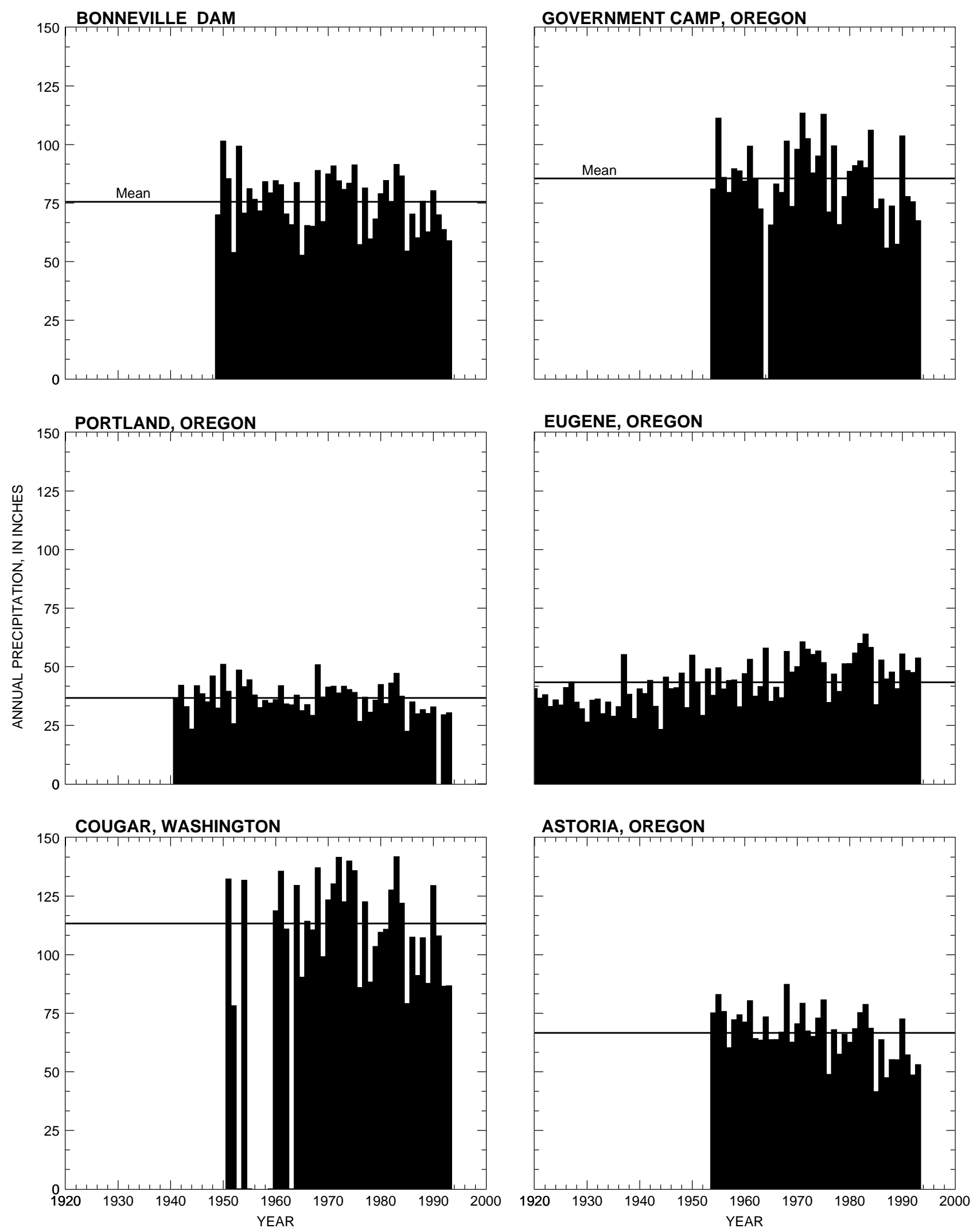

Figure 3. Annual and mean annual precipitation at Bonneville Dam, Government Camp, Portland, Eugene, Cougar, and Astoria, lower Columbia River Basin, Oregon and Washington, 1920-93. 
PORTLAND, OREGON 1941-93

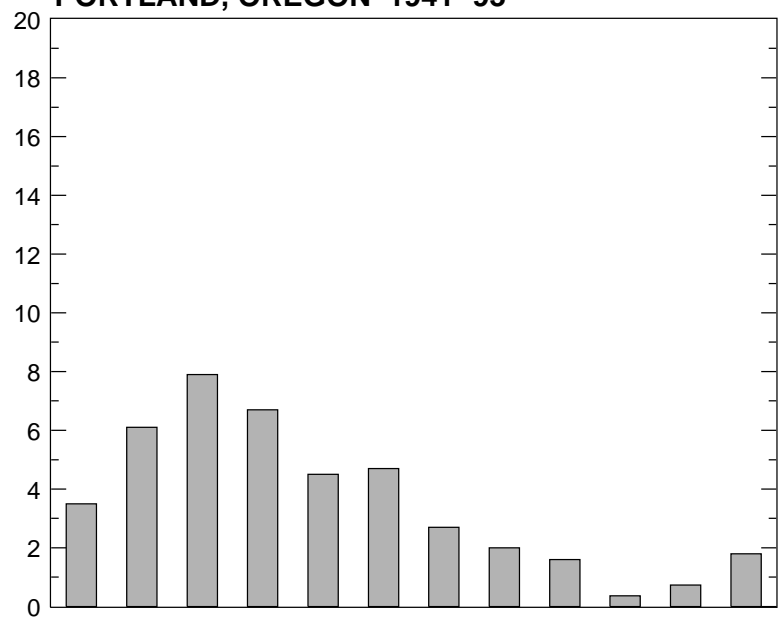

COUGAR, WASHINGTON 1948-93

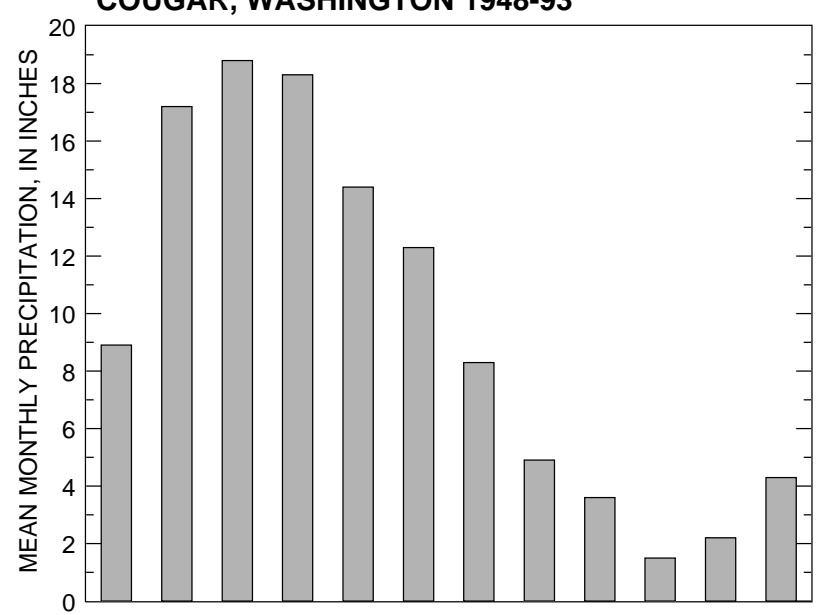

EUGENE, OREGON 1905- 93

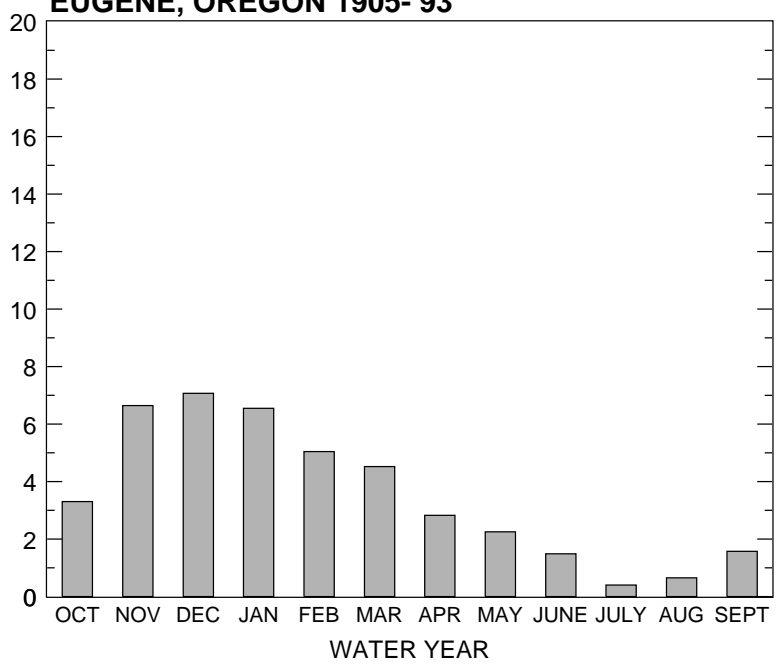

Figure 4. Mean monthly precipitation at Portland, Cougar, and Eugene, lower Columbia River Basin, Oregon and Washington.
In the Columbia River, streamflow is typically high in spring during the snowmelt season. Although winter streamflows are high because of winter rains, they are generally not as high as during snowmelt. Streamflows peaked as a result of spring snowmelt during the months of April, May, and June for the 1956 WY and during June for the 1967 WY (fig. 5). There was, however, no spring peak in the 1977 WY. The 1956, 1967, and 1977 WY's represent, respectively, the high-flow $\left(351,000 \mathrm{ft}^{3} / \mathrm{s}\right)$, medianflow $\left(259,000 \mathrm{ft}^{3} / \mathrm{s}\right)$, and low-flow $\left(153,000 \mathrm{ft}^{3} / \mathrm{s}\right)$ water years for the period 1928-84 (fig. 6) - based on mean daily streamflow in the Columbia River at mouth (Orem, 1968; U.S. Geological Survey, 1972 75, 1976-80, 1981-84). Peak daily mean streamflows during snowmelt seasons have ranged from $917,000 \mathrm{ft}^{3} / \mathrm{s}$ during June of 1948 to only $179,800 \mathrm{ft}^{3} / \mathrm{s}$ during May of 1977.

The spring snowmelt season usually coincides with the major streamflows of the year. During 1967, a year of median streamflow, more than 40 percent of the annual streamflow in the Columbia River at Vancouver was discharged from April through June during the spring snowmelt period (table 1). During the 1994 WY, however, spring snowmelt runoff was notably less than during the 1967 median streamflow year (fig. 7). The annual mean streamflow (172,100 $\mathrm{ft}^{3} / \mathrm{s}$ ) measured in the Columbia River at Beaver Army Terminal near Quincy for the 1994 WY is among the lowest 10 percent for the period 1928-85.

The Willamette River's seasonal streamflow pattern is different from that of the Columbia River. In 1967, the Willamette River discharged only 16 percent of its annual streamflow during spring and 64 percent during the December through March winter months (table 1). In contrast, 41 percent of the streamflow in the Columbia River at Vancouver was discharged during spring and only 24 percent during winter. The 1994 hydrographs for the Columbia and Willamette Rivers (fig. 8) illustrate the same seasonal streamflow patterns-peak flows on the Columbia River were during May and June, and on the Willamette River, rainstorm-driven peaks were measured from January through April and again from November through December. 


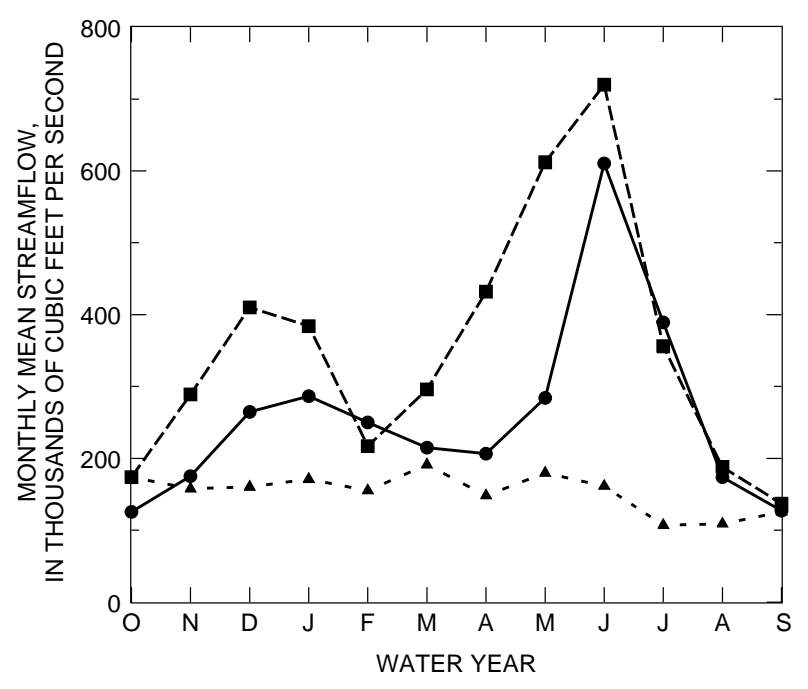

EXPLANATION

- HIGH-STREAMFLOW YEAR, 1956 WATER YEAR

- MEDIAN-STREAMFLOW YEAR, 1967 WATER YEAR

- LOW-STREAMFLOW YEAR, 1977 WATER YEAR

Figure 5. Estimated monthly mean streamflow in the Columbia River at mouth near Astoria for the low-, median-, and high-streamflow years, lower Columbia River Basin, Oregon.

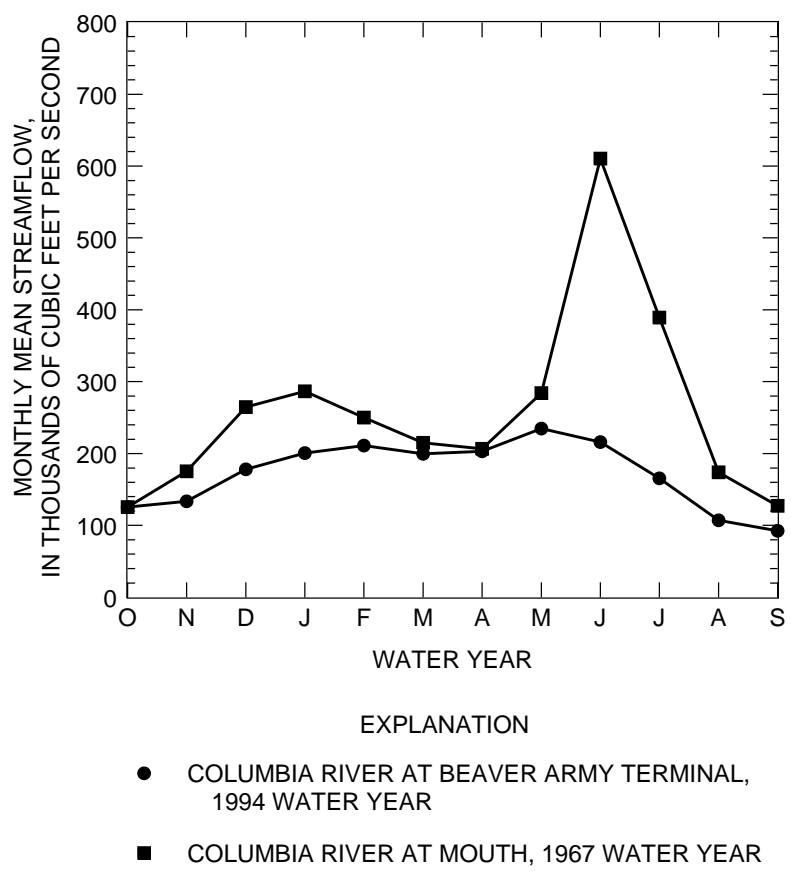

Figure 7. Estimated monthly mean streamflow in the Columbia River at mouth near Astoria, 1967 water year, and Columbia River at Beaver Army Terminal near Quincy, 1994 water year, lower Columbia River Basin, Oregon and Washington.

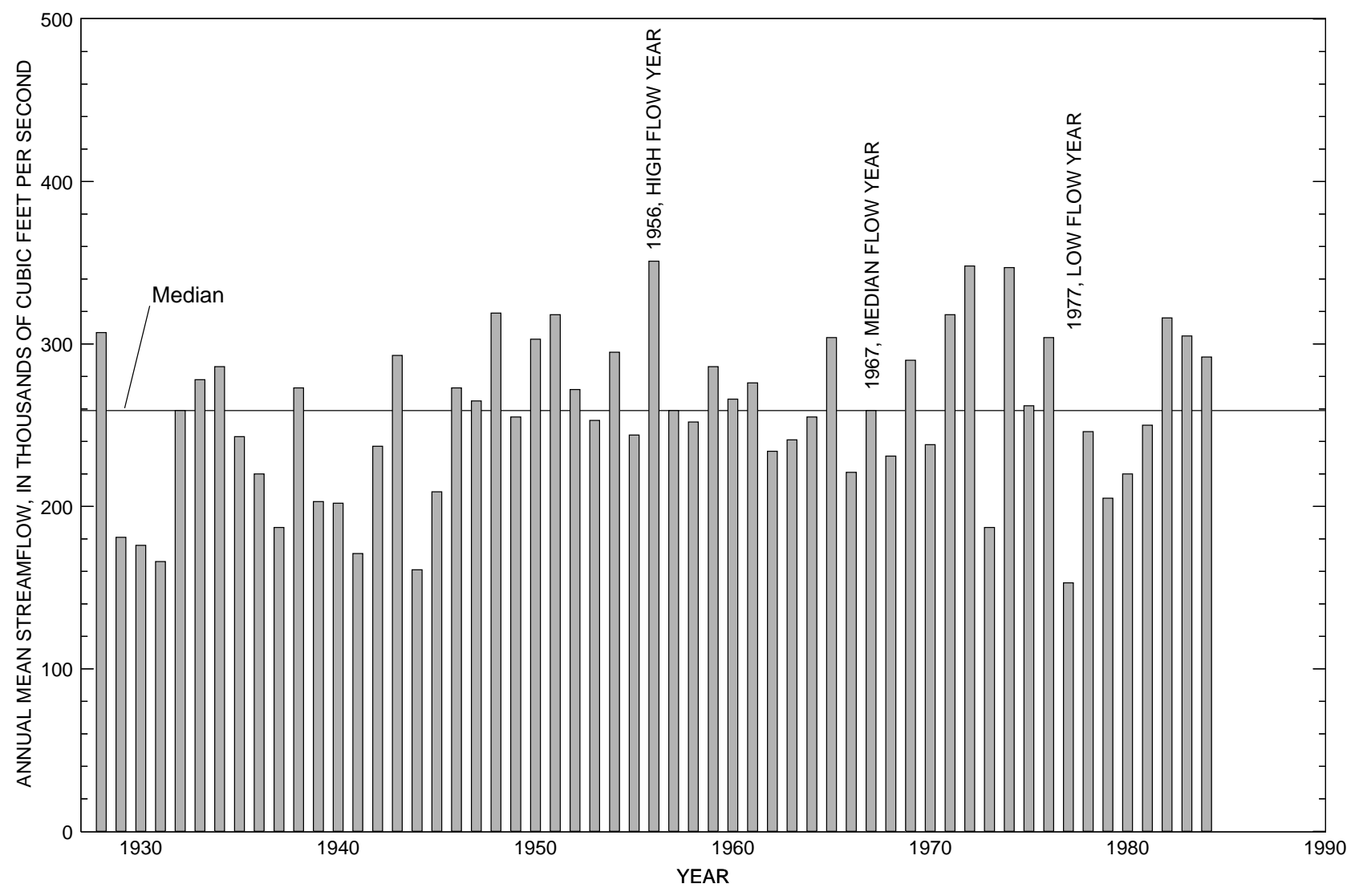

Figure 6. Annual mean streamflow and median annual streamflow for the Columbia River at mouth, 1928-84. (Data from Orem, 1968; U.S. Geological Survey, 1972-75, 1975-80, 1981-84.) 
Table 1. Summary statistics for seasonal variations in streamflow at selected sites, lower Columbia River Basin, Oregon and Washington, 1967 water year

[Streamflow reported in thousands of cubic feet per second; Vancouver, Columbia River at Vancouver; Willamette, Willamette River at Portland; St. Helens, Columbia River at St. Helens; Longview, Columbia River at Longview; Astoria, Columbia River at mouth near Astoria; data are for the 1967 water year, a median-streamflow year for the period 1928-85; Fall, October to November; Winter, December to March; Spring, April to June; Summer, July to September]

\begin{tabular}{l|cccc|cccc}
\hline \multirow{2}{*}{ Site name } & \multicolumn{3}{|c|}{ Percent of the annual streamflow } & \multicolumn{4}{c}{ Mean monthly streamflow } \\
\cline { 2 - 9 } & Fall & Winter & Spring & Summer & Fall & Winter & Spring & Summer \\
\hline Vancouver & 9 & 24 & 41 & 26 & 105 & 146 & 332 & 213 \\
Willamette & 14 & 64 & 16 & 6 & 27.0 & 65.0 & 19.6 & 7.5 \\
St. Helens & 10 & 30 & 37 & 23 & 138 & 219 & 356 & 221 \\
Longview & 10 & 32 & 36 & 22 & 144 & 239 & 368 & 224 \\
Astoria & 10 & 32 & 35 & 23 & 150 & 254 & 367 & 233 \\
\hline
\end{tabular}

\section{Land and Water Use}

Major land-use categories ${ }^{1}$ in the lower Columbia River Basin include forest land (74 percent) and agricultural land (17 percent) (table 2). Urban lands comprise a relatively small part (5 percent) of the basin, but are significant to water use and water quality. Intensive water use by cities and some agricultural areas makes these land uses of primary importance to water-quality issues. Most of the agricultural land in the lower Columbia River Basin is in the Willamette River Basin (fig. 9). Although the Willamette River Basin makes up 65 percent of the area in the lower Columbia River Basin, it contains 89 percent of the lower basin's agricultural land.

Population in the lower Columbia River Basin was about 2,344,800 in 1990 (T.M. Broad and C.A. Collins, USGS, unpub. data, 1993), with more than 80 percent residing in the Willamette River Basin. As a result, the Willamette River Basin ranks high in terms of water use in the lower Columbia River Basin (table 3), accounting for more than 60 percent of the surface-water and ground-water withdrawals in the lower Columbia River Basin. Commercial ${ }^{2}$, industrial $^{3}$, livestock, and irrigation withdrawals in the Willamette River Basin are large in comparison

\footnotetext{
${ }^{1}$ Land-use data are from the EPA's 1980 land-use and landcover digital data (U.S. Environmental Protection Agency, 1994a), which uses the Anderson classification system of land use and land cover (Anderson and others, 1976).

${ }^{2}$ Water used for motels, hotels, restaurants, office buildings, and other commercial facilities, and institutions, both civilian and military.
}

to other subbasins in the lower Columbia River Basin. In the Willamette River Basin, for example, industrial and irrigation withdrawals, respectively, represent 55 and nearly 87 percent of the total industrial and irrigation withdrawals in the lower Columbia River Basin.

\section{Point Sources}

In this report, point sources are defined as pipe or outfall discharges from municipalities and industries. These sources may flow directly into the main stem of the Columbia River or into one of its tributaries. Nonpoint sources include diffuse sources such as overland runoff and ground-water discharge. Both point and nonpoint sources may degrade water quality; however, point sources are usually more easily identified and controlled. In addition, point sources include combined-sewer overflows (CSO), which usually occur in the winter in the Willamette River and the Columbia Slough, which drains to the lower Willamette River. Between RM 0 and 25 in the Willamette River, there are a total of 38 CSOs and another 13 in the first 10 river miles of the Columbia Slough (Warner and others, 1992).

One hundred and two point sources were identified as directly connected to the main stem or located within the first 16 river miles of tributaries (table 46, at back of report). These sources are

\footnotetext{
${ }^{3}$ Water used in processing, washing, cooling in facilities that manufacture products such as steel, chemical and allied products, paper and allied products, and petroleum refining.
} 

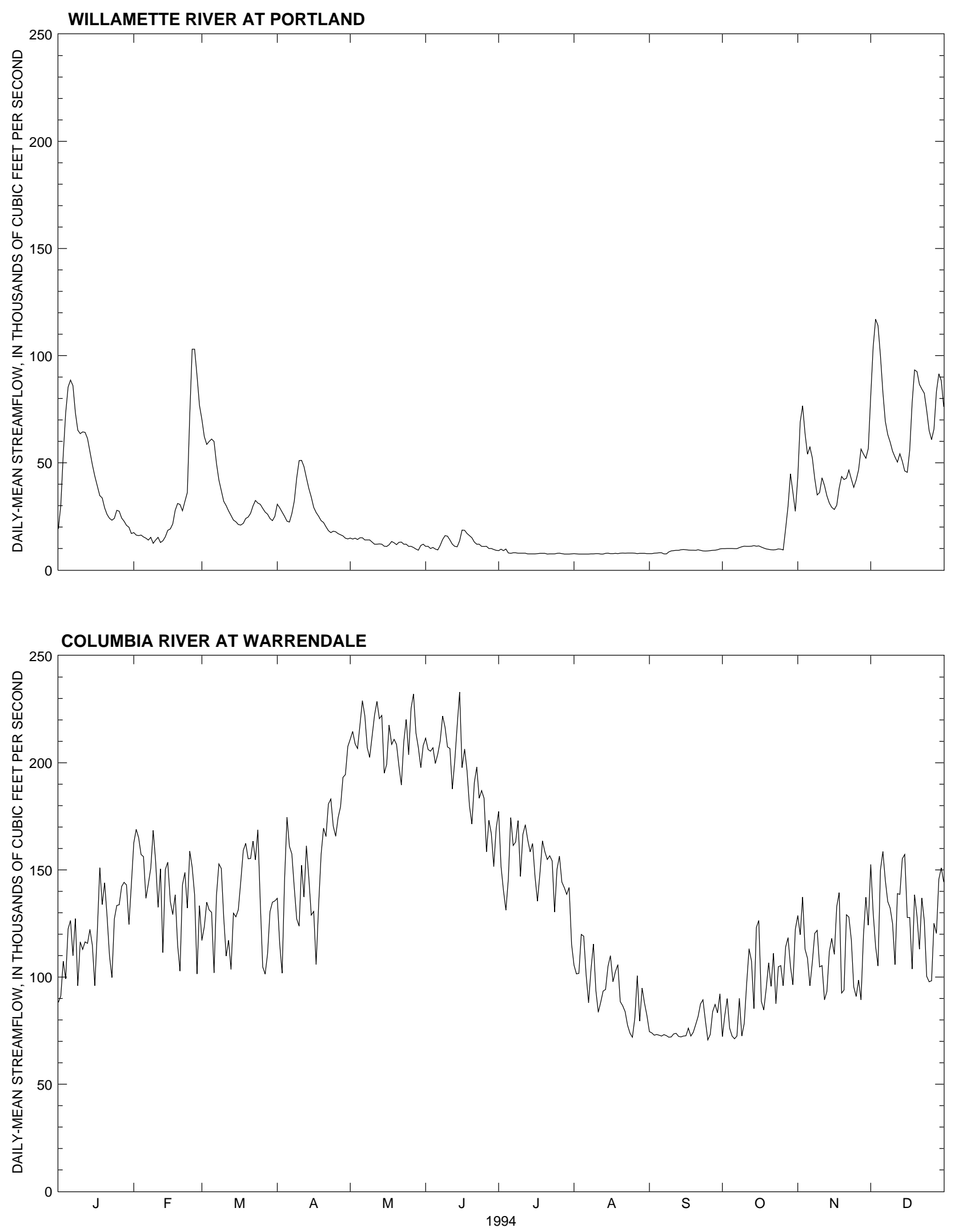

Figure 8. Streamflows in the Willamette River at Portland and Columbia River at Warrendale, lower Columbia River Basin, Oregon and Washington, 1994. (Data for the Columbia River at Warrendale are outflow from Bonneville Dam from the U.S. Army Corps of Engineers.) 
Table 2. Percentage of land in specific land-use and land-cover categories, lower Columbia River Basin, Oregon and Washington, 1980

[Land-use percentages from U.S. Environmental Protection Agency, 1994a; \%, percent]

\begin{tabular}{l|ccccc|c}
\hline \multicolumn{1}{c|}{ Area name } & $\begin{array}{c}\text { Urban } \\
\text { land }\end{array}$ & $\begin{array}{c}\text { Agricultural } \\
\text { land }\end{array}$ & $\begin{array}{c}\text { Forest } \\
\text { land }\end{array}$ & $\begin{array}{c}\text { Water bodies } \\
\text { and wetlands }\end{array}$ & $\begin{array}{c}\text { Other } \\
\text { land }\end{array}$ & $\begin{array}{c}\text { Total land area } \\
\text { (square miles) }\end{array}$ \\
\hline Lower Columbia River Basin & $5 \%$ & $17 \%$ & $74 \%$ & $3 \%$ & $1 \%$ & 17,670 \\
$\begin{array}{l}\text { Willamette River Basin } \\
\text { (Hydrologic Units }\end{array}$ & $5 \%$ & $23.5 \%$ & $69.5 \%$ & $1 \%$ & $1 \%$ & 11,426 \\
$\begin{array}{l}\text { 17090001-17090012) } \\
\text { Non-Willamette areas of the } \\
\text { lower Columbia River Basin } \\
\text { (Hydrologic Units } \\
\text { 17080001-17080006) }\end{array}$ & $4 \%$ & $5 \%$ & $83 \%$ & $5 \%$ & $3 \%$ & 6,244 \\
\hline
\end{tabular}

facilities that have National Pollutant Discharge Elimination System (NPDES) permits to discharge wastewater. These facilities were classified according to their primary function in order to examine the pollution contributions of different types of industries and their resulting wastewater (table 4). The largest category of point sources is domestic facilities, which are primarily sewagetreatment plants. The locations of these facilities are shown in figure 10. All other point sources are shown in figure 11.

ODEQ and WDOE issue and enforce the NPDES permits in Oregon and Washington. These permits specify the discharge limits that must not be exceeded during the operation of the facility and the frequency and type of monitoring that must be performed. The information in table 46 (at back of report) was obtained from the permit files of ODEQ and from the permits database of WDOE.

Information on point sources that discharge directly into the Columbia River came from a report done by Tetra Tech, Inc. for the Lower Columbia River BiState Program (Tetra Tech, Inc., 1992). The permit levels for effluent discharge shown in table 46 (at back of report) represent average or maximum permitted effluent quantities and do not necessarily represent actual discharges. Caution should be taken in comparing values in the table because the time frame that the levels are based on differs with each facility. For some facilities, limits have not been set on flow, and levels are based on the "average dryweather design flow" to the facility. Facilities that are classified as "industrial" by ODEQ or WDOE have limits on the concentrations of selected constituents in their discharge and not on their discharge rate. Likewise, facilities that discharge stormwater do not have flow limits.

Figure 10 shows only those facilities classified as domestic. The largest sources of effluent volume are the Portland (Columbia Boulevard) and Vancouver (East and West) sewage-treatment plants, which serve the largest populations within 16 river miles of the lower Columbia River. Figure 12 shows facilities that fall in the next three largest categories: chemical plants, seafood processing plants, and other miscellaneous facilities, respectively. The largest sources of effluent volume for these categories are Elf Atochem North America, Inc., an inorganic chemical manufacturer in Portland, and Chevron Chemical Company, a fertilizer plant in St. Helens.

\section{DATA SOURCES AND METHODS OF ANALYSIS}

The purposes of this study include examining the spatial and temporal variations in water-quality constituent concentrations, loads, and trends in the lower Columbia River Basin and describing the suitability of surface water for the preservation of aquatic life and the protection of human health. In order to meet these goals, it was necessary not only to collect water-quality data, but also to compile and analyze data that had been previously collected. The current and past data were then related in a common framework in an effort to understand the water quality of the River. 
Table 3. Water use in the lower Columbia River Basin, Oregon and Washington, 1990 water year [Mgal/d, million gallons per day; --, no data; water-use data from Broad and Collins, USGS, unpub. data, 1993]

\begin{tabular}{|c|c|c|c|c|c|c|c|c|c|}
\hline \multirow[b]{2}{*}{$\begin{array}{l}\text { Hydrologic unit or } \\
\text { subbasin name }\end{array}$} & \multirow{2}{*}{ 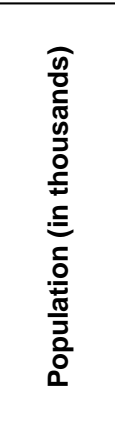 } & \multirow[b]{2}{*}{ 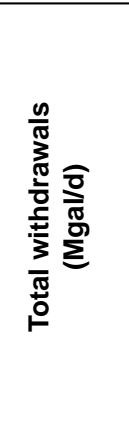 } & \multicolumn{5}{|c|}{$\begin{array}{l}\text { Selected withdrawals } \\
(\text { (Mgal/d) }\end{array}$} & \multirow{2}{*}{ 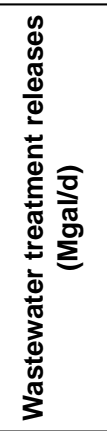 } & \multirow[b]{2}{*}{ 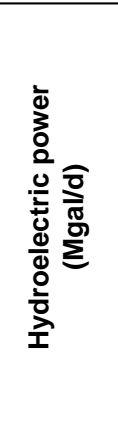 } \\
\hline & & & $\begin{array}{l}\frac{1}{ \pm} \\
\frac{\pi}{\pi} \\
3 \\
\frac{2}{0} \\
00 \\
00 \\
0 \\
00 \\
\frac{0}{3}\end{array}$ & 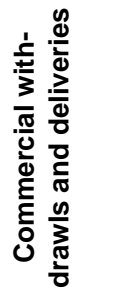 & 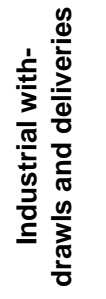 & 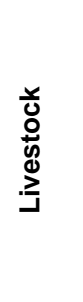 & 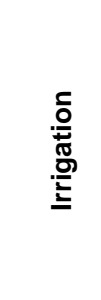 & & \\
\hline Lower Columbia-Sandy, Oregon & 31 & 170 & 120 & 45 & 0.4 & 0.1 & 1.2 & 5.9 & 100,000 \\
\hline Lower Columbia-Sandy, Washington & 210 & 136.5 & 29.7 & 4.1 & 90.4 & .91 & 13.7 & 55 & 0 \\
\hline $\begin{array}{l}\text { Willamette River Subbasin. Oregon } \\
\text { (including Lower Willamette Unit) }\end{array}$ & $1,927.6$ & 1,100 & 170 & 235 & 220 & 3.7 & 358.4 & 4.8 & 20,000 \\
\hline Lewis, Washington & 36.2 & 19 & .98 & .14 & .01 & 0 & 14.7 & .32 & 9,983 \\
\hline Lower Columbia-Clatskanie, Oregon & 21.4 & 92 & 2.1 & 13 & 60 & -- & 1.3 & 36 & 0 \\
\hline Lower Columbia-Clatskanie, Washington & 49.9 & 26.7 & 6.2 & .55 & 13.5 & .16 & 5.9 & 44 & 0 \\
\hline Cowlitz River Subbasin, Washington & 44.4 & 164 & 4.5 & .37 & 17.3 & 1.2 & 16.8 & 2.4 & 1,950 \\
\hline Lower Columbia (estuary), Oregon & 22.7 & 52 & 7.2 & 45 & 1.2 & .1 & .3 & 4.7 & 0 \\
\hline Lower Columbia (estuary), Washington & 1.57 & .18 & .13 & 0 & 0 & 0 & 0 & .3 & 0 \\
\hline Total & $2,344.8$ & $1,760.4$ & 340.8 & 343.2 & 402.8 & 6.2 & 412.3 & 153.4 & 131,933 \\
\hline
\end{tabular}




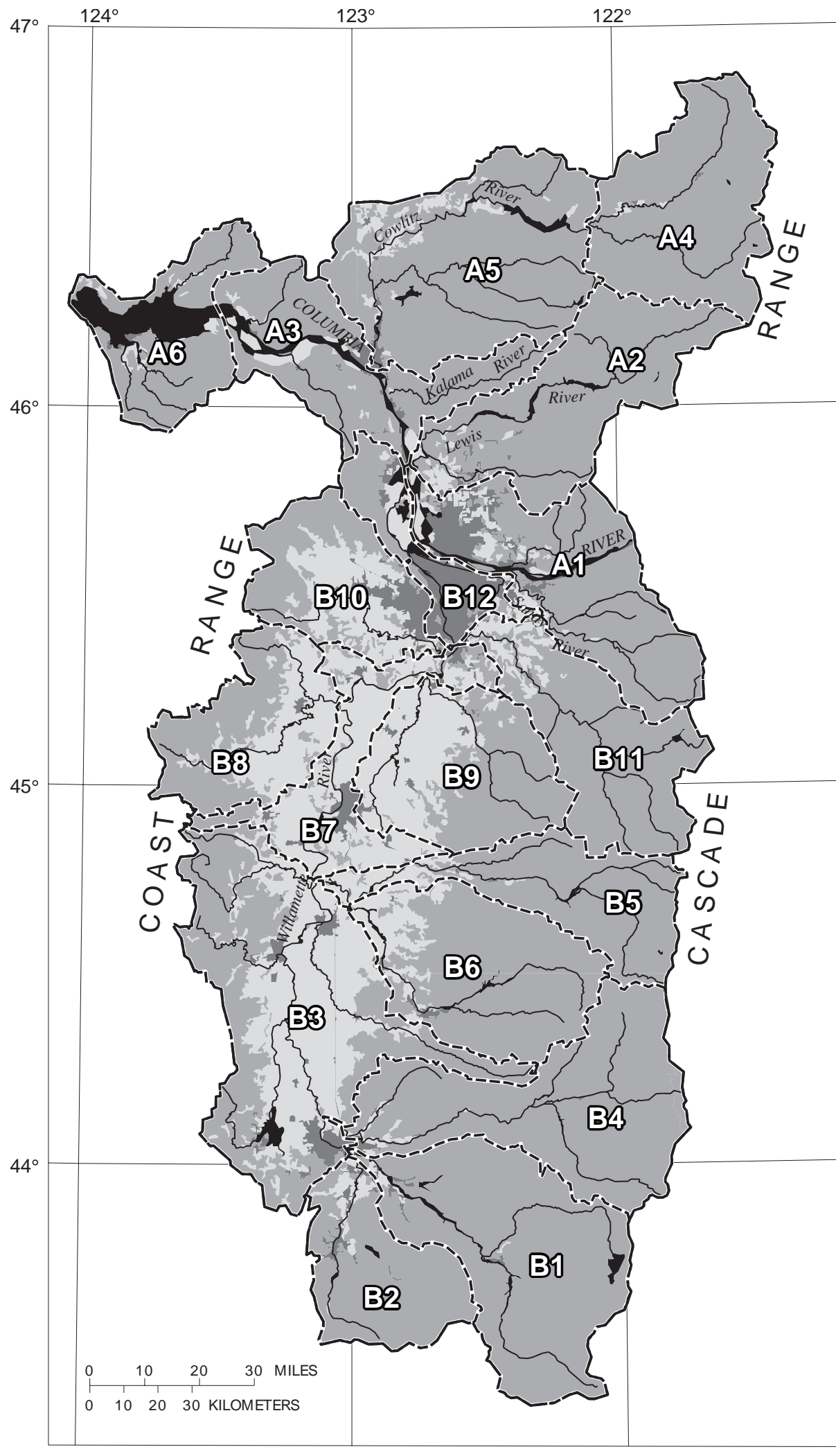

\section{EXPLANATION}

Urban lands

Agricultural lands

Forest lands

Water and wetlands

--- Hydrologic unit border

- Basin border

Aป Hydrologic unit code

Figure 9. Land use and land cover by hydrologic units, lower Columbia River Basin, Oregon and Washington, 1980. 
Table 4. Inventory of point-source classifications, lower Columbia River Basin, Oregon and Washington

\begin{tabular}{lc}
\hline \multicolumn{1}{c}{ Source classification } & $\begin{array}{c}\text { Number } \\
\text { of } \\
\text { facilities }\end{array}$ \\
\hline Domestic & 39 \\
Chemical & 12 \\
Wood products and wood treatment & 11 \\
Miscellaneous & 10 \\
Seafood processing & 8 \\
Paper and pulp & 5 \\
Aluminum & 4 \\
Boat yard & 3 \\
Fish hatchery & 3 \\
Remediation (site cleanup) & 3 \\
Power generating & 2 \\
Tank farm (storage) & 2 \\
\hline
\end{tabular}

\section{Current and Historical Sources of Data}

Data collected in 1994 are referred to as current data, and data collected before 1994 are referred to as historical data. Current data were collected by the USGS, ODEQ, and WDOE, whereas historical data span a longer timeframe and were collected by many agencies.

\section{Historical Data}

Water-quality data for more than 200 parameters collected from streams in the lower Columbia River Basin over more than 50 years were collated for interpretation in this report. These data are from three sources: EPA's STOrage and RETreival (STORET) database, USGS's National Water Information System (NWIS) database, and Tetra Tech, Inc. synoptic studies. The retrievals were confined to the hydrologic units inside the lower Columbia River Basin (table 5). The STORET retrieval consisted of data from non-USGS agencies including EPA, U.S. Forest Service, ODEQ, and WDOE; the NWIS retrieval consisted only of USGS data.

Water-quality data of particular relevance were collected at the following three fixed sites in the lower Columbia River Basin as part of the USGS's NAtional Stream Quality Accounting Network (NASQAN):

Columbia River at Warrendale (RM $141.0-$ 1973 to October 1993) Willamette River at Portland (RM 12.8-October 1974 to current year) Columbia River at Beaver Army Terminal (RM 53.8November 1990 to current year).

In 1992, the NASQAN site at Warrendale was moved to Beaver Army Terminal to obtain a better accounting of constituents leaving the Columbia River Basin. Prior to discontinuing data collection at Warrendale, however, the NASQAN program funded the sampling of concurrent data in 1992 from Warrendale and Beaver Army Terminal. As a result of Bi-State interest in the lower Columbia River Basin, the NASQAN program funded continued operation of the Warrendale site through October 1993. The NASQAN suite of constituents measured at the Warrendale and Beaver Army Terminal sites is not extensive. More constituents were measured during 1993-95 at the Willamette River site, however, because of other USGS programs sampling there. The sampling was partially funded by the USGS's National Water Quality Assessment (NAWQA) program (1993-95) in the Willamette Basin (Leahy and Thompson, 1994), and by a Willamette State Study cooperative program (1993-95) between the USGS and ODEQ. NASQAN samp-ling at these three sites was done once every 2 months, but sampling at the Willamette River site was done once a month during 1993-95 because of the other programs. Few samples were collected for priority pollutant trace elements and organic compounds.

Through the Bi-State Program, Tetra Tech, Inc. performed two synoptic studies on the lower Columbia River. A reconnaissance survey of the main stem during September to November 1991 was implemented to make a preliminary assessment of water-quality conditions and to direct future Bi-State studies (Tetra Tech, Inc., 1993). Four environmental media (water, streambed sediments, fish tissue, and benthic organisms) were sampled. For this report, however, interpretation of historical data was restricted to the 45 sites for which the water column was sampled. Due to high method reporting limits and data flagged as "unusable," only selected parameters $(\mathrm{pH}$, turbidity, dissolved oxygen 


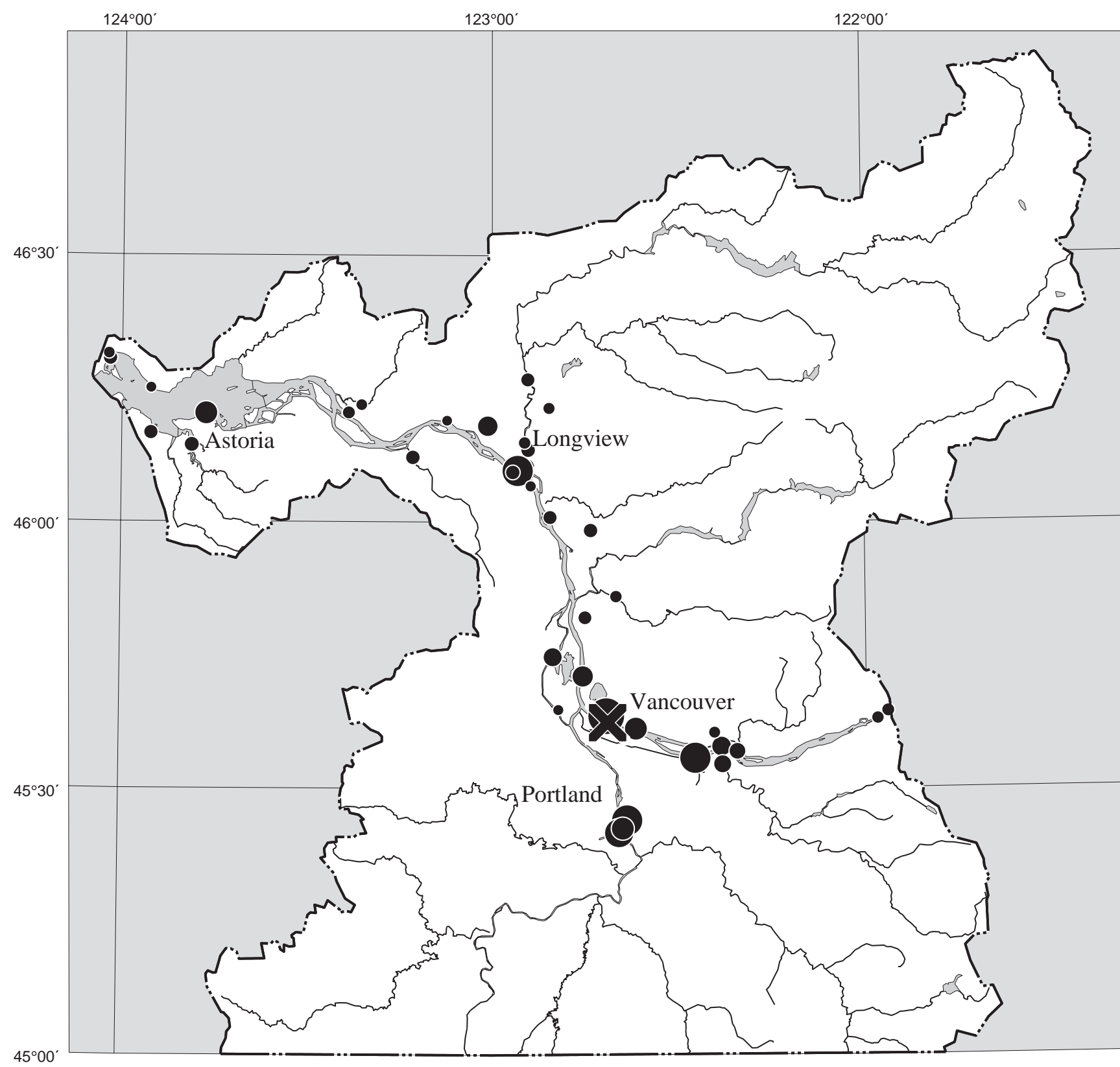

\section{EXPLANATION}

Effluent discharge levels - In millions of gallons per day

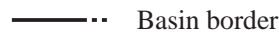

$\dot{x}$

15.2

100 (Portland Sewage Treatment Plant)

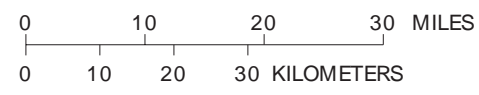

Figure 10. Point-source domestic discharges, lower Columbia River Basin, Oregon and Washington, 1994. 


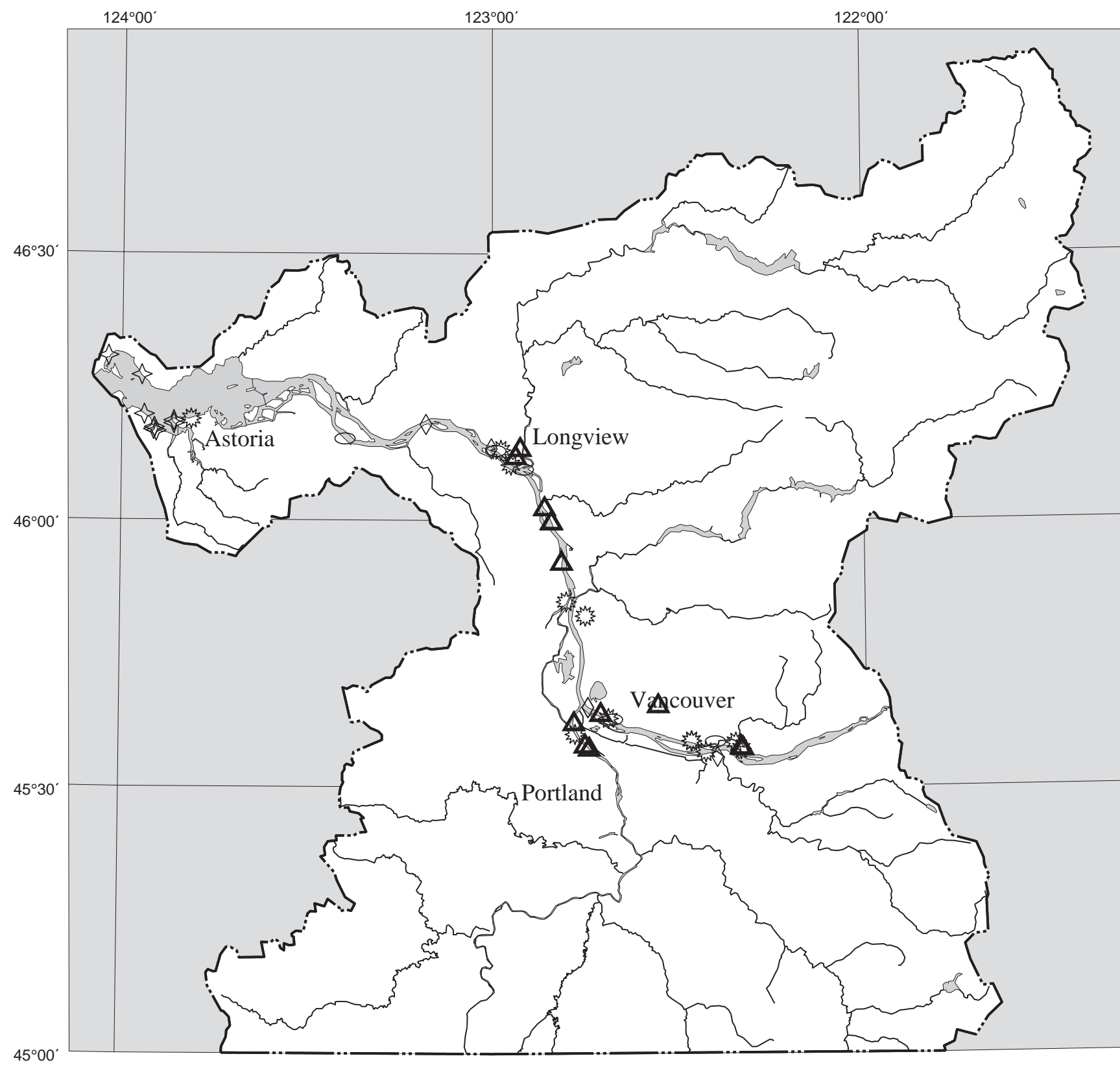

\section{EXPLANATION}
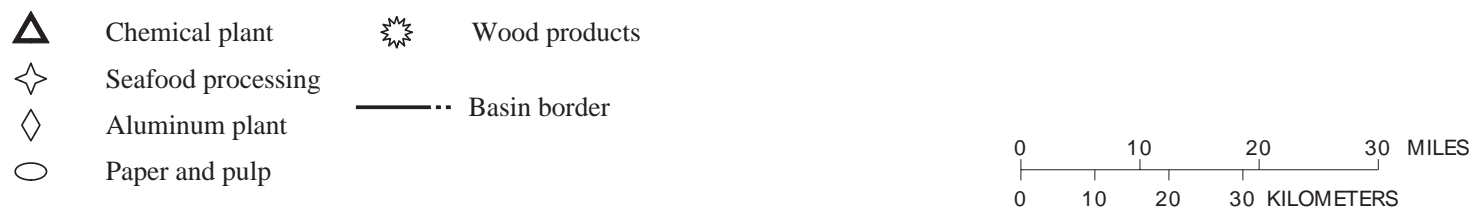

Figure 11. Locations of point sources other than domestic discharge, lower Columbia River Basin, Oregon and Washington, 1994. 


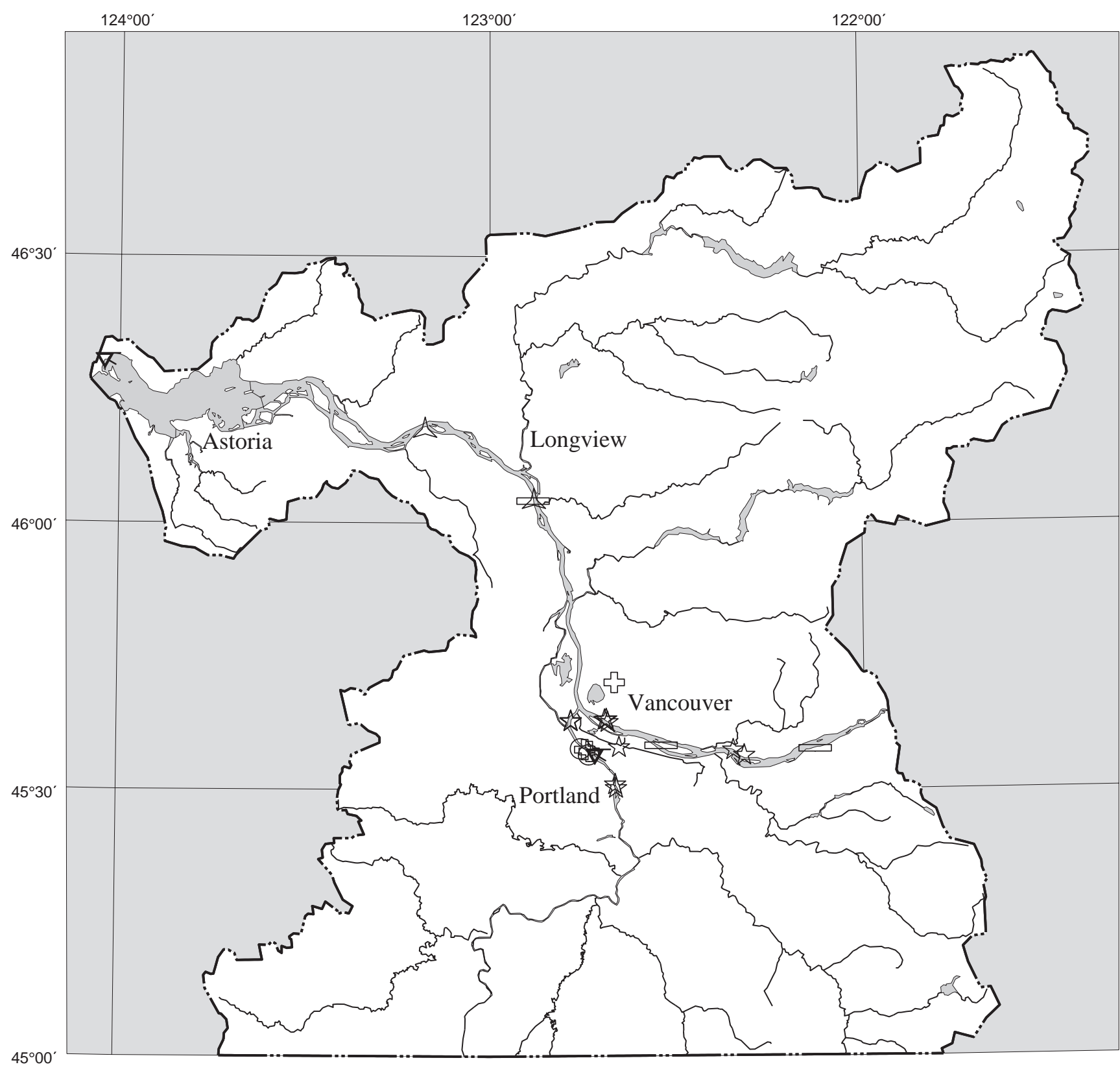

\section{EXPLANATION}

$\begin{array}{llll}\nabla & \begin{array}{l}\text { Boat yard } \\ \Delta\end{array} & \begin{array}{l}\text { Power generation } \\ \text { Fish hatchery }\end{array} & \begin{array}{l}\text { Remediation } \\ \text { Miscellaneous }\end{array} \\ & \begin{array}{l}\text { Tank farm } \\ \text { Tar }\end{array} & \text { Basin border }\end{array}$

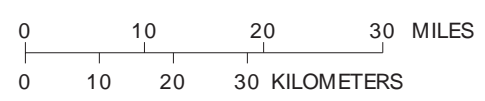

Figure 11. Locations of point sources other than domestic discharge, lower Columbia River Basin, Oregon and Washington, 1994-Continued. 


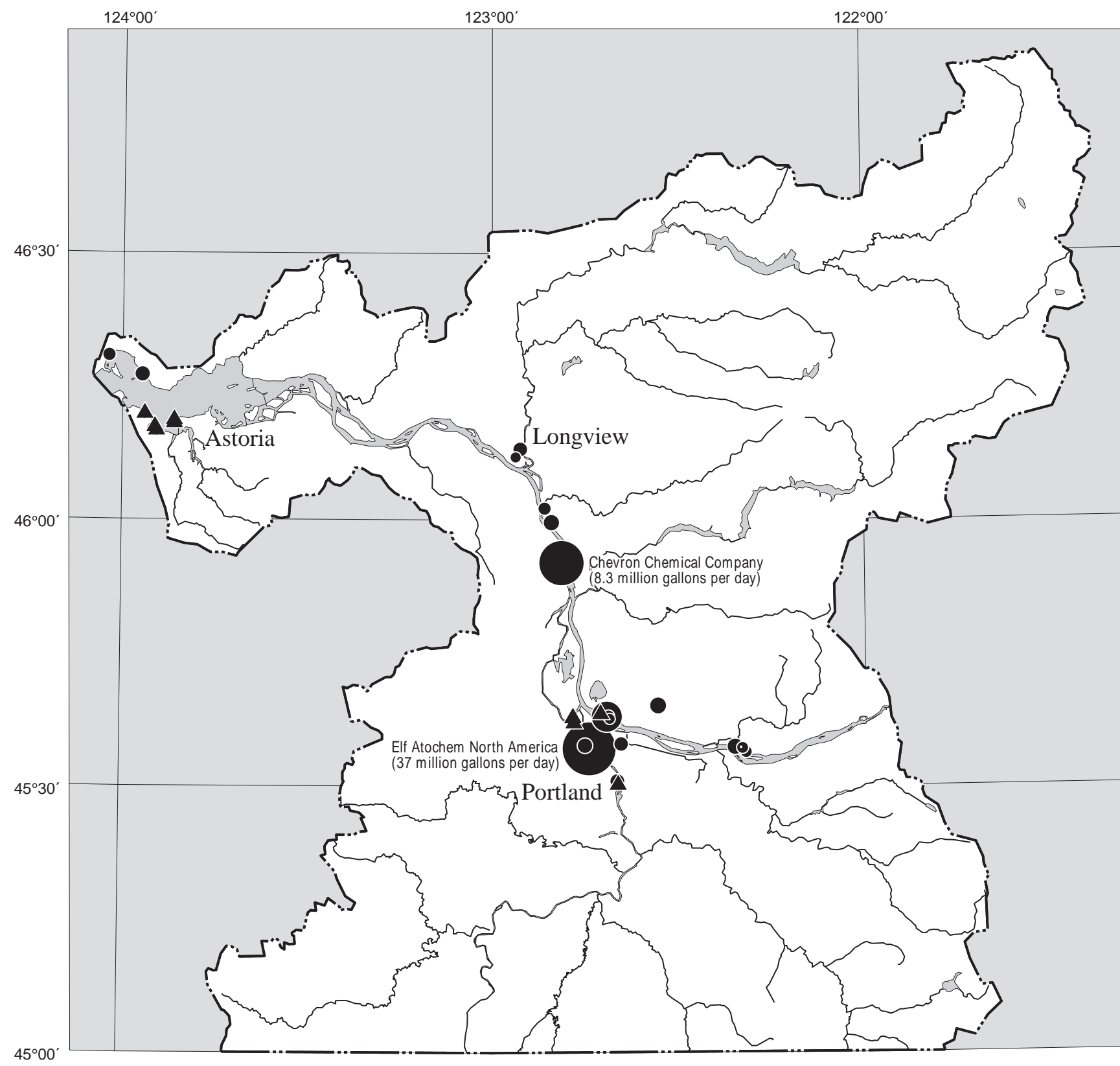

\section{EXPLANATION}

Effluent discharge levels - In millions of gallons per day

- $\quad 0.003285$

- 37
No discharge data available

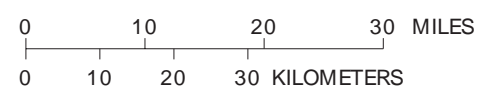

Figure 12. Point-source discharges for chemical, seafood processing, and other miscellaneous facilities, lower Columbia River Basin, Oregon and Washington, 1994. 
Table 5. Hydrologic units included in historical data retrievals and subbasin units used for analysis of historical data, lower Columbia River Basin, Oregon and Washington

[Historical data was retrieved for all hydrologic units except 17080004; hydrologic unit descriptions from U.S. Geological Survey, 1982]

\begin{tabular}{|c|c|c|}
\hline $\begin{array}{l}\text { Hydrologic } \\
\text { unit }\end{array}$ & Hydrologic unit name & $\begin{array}{l}\text { Subbasin or unit name used for } \\
\text { analysis of historical data }\end{array}$ \\
\hline 17080001 & Lower Columbia-Sandy, Oregon, Washington & Lower Columbia-Sandy, Oregon \\
\hline 17080001 & Lower Columbia-Sandy, Oregon, Washington & Lower Columbia-Sandy, Washington \\
\hline 17080002 & Lewis, Washington & Lewis River Subbasin \\
\hline 17080003 & Lower Columbia-Clatskanie, Oregon, Washington & Lower Columbia-Clatskanie \\
\hline 17080004 & Upper Cowlitz, Washington & Cowlitz River Subbasin \\
\hline 17080005 & Lower Cowlitz, Washington & Cowlitz River Subbasin \\
\hline 17080006 & Lower Columbia, Oregon, Washington & Lower Columbia (estuary) Unit \\
\hline 17090001 & Middle Fork Willamette, Oregon & Willamette River Subbasin \\
\hline 17090002 & Coast Fork Willamette, Oregon & Willamette River Subbasin \\
\hline 17090003 & Upper Willamette, Oregon & Willamette River Subbasin \\
\hline 17090004 & McKenzie, Oregon & Willamette River Subbasin \\
\hline 17090005 & North Santiam, Oregon & Willamette River Subbasin \\
\hline 17090006 & South Santiam, Oregon & Willamette River Subbasin \\
\hline 17090007 & Middle Willamette, Oregon & Willamette River Subbasin \\
\hline 17090008 & Yamhill, Oregon & Willamette River Subbasin \\
\hline 17090009 & Molalla-Pudding, Oregon & Willamette River Subbasin \\
\hline 17090010 & Tualatin, Oregon & Willamette River Subbasin \\
\hline 17090011 & Clackamas, Oregon & Willamette River Subbasin \\
\hline 17090012 & Lower Willamette, Oregon & Lower Willamette Unit \\
\hline
\end{tabular}

temperature, specific conductance, salinity, total suspended solids, chloride, sulfate, hardness, fecalcoliform bacteria, and enterococcal bacteria) were examined. In 1993, a second synoptic study was performed to supplement the 1991 data (Tetra Tech, Inc., Redmond, Washington, unpub. data, 1994). During this survey, water, streambed-sediment, and fish-tissue samples were collected in backwater areas (locations isolated from the main river current with an outlet to the main channel, for example, sloughs and back channels) of the lower Columbia River. The interpretation for the present report was limited to the 15 sites for which the water column was sampled. The parameters of interest were mainly physical properties, nutrients, bacteria, and trace elements.

Historical water-quality data were categorized into eight constituent groups: (1) major ions;

(2) water temperature and $\mathrm{pH}$; (3) dissolved oxygen;

(4) nutrients, including those constituents containing nitrogen and phosphorus; (5) trace elements; (6) organic compounds, including organic carbon, pesticides, and priority organic pollutants as identified by the EPA (U.S. Environmental Protection Agency, 1995); (7) suspended-sediment concentrations in water; and (8) bacteria, including fecal coliform and enterococci. The number of historical determinations for each of these groups is shown in figure 13. Data from the Willamette River Basin are also shown separately in the figure to illustrate the fact that most of the historical data that are available for the lower Columbia River Basin comes from the Willamette River Basin. Table 6 provides an overview of the sites with the most determinations, by constituent group, in the basin. From this table, it can be seen that the Bull Run Watershed (Portland's drinking-water source) has been frequently sampled in the past. 
Table 6. Sites that have the most water-quality determinations from 1939-93, lower Columbia River Basin, Oregon and Washington

[Listed are the five sites with the most water-quality data values for each constituent group; USFS, U.S. Forest Service; EPA, U.S. Environmental Protection Agency; ODEQ, Oregon Department of Environmental Quality; USGS, U.S. Geological Survey; NA, not available; sources of data: EPA's STOrage and RETrieval System, USGS's National Water Inventory System, Tetra Tech, Inc., 1993; and Tetra Tech, Inc., Redmond, Washington, unpub. data, 1994]

\begin{tabular}{|c|c|c|c|}
\hline Site number & Site name & Sampling agency & $\begin{array}{l}\text { Number of } \\
\text { data values }\end{array}$ \\
\hline \multicolumn{4}{|c|}{ Major Ions } \\
\hline 4527001220900 & Bull Run Reservoir at Headworks & USFS, EPA & 12,647 \\
\hline 4526001220200 & Fox Creek & USFS & 10,026 \\
\hline 4533491224317 & Willamette S.I. Monitor & EPA & 6,310 \\
\hline 4527001220700 & South Fork at S-111 & USFS & 3,418 \\
\hline 4534461224442 & Willamette River at SP\&S Railroad Bridge & NA & 3,253 \\
\hline \multicolumn{4}{|c|}{ Water Temperature and $\mathrm{pH}$} \\
\hline 4527001220900 & Bull Run Reservoir at Headworks & USFS, EPA & 24,273 \\
\hline 4530001220300 & Cougar Creek/ Deer Creek at S-10 & USFS & 6,081 \\
\hline 4533491224317 & Willamette S.I. Monitor & EPA & 5,875 \\
\hline 4527001220700 & South Fork at S-111 & USFS & 4,875 \\
\hline 4530001225400 & Otter Creek/ Log Creek/ Blazed Alder Creek & USFS & 4,699 \\
\hline \multicolumn{4}{|c|}{ Dissolved Oxygen } \\
\hline 4527001220900 & Bull Run Reservoir at Headworks & USFS, EPA & 10,950 \\
\hline 4533491224317 & Willamette S.I. Monitor & EPA & 5,694 \\
\hline 4534411224451 & Willamette River at SP\&S Railroad Bridge & ODEQ & 1,958 \\
\hline 4534461224442 & Willamette River at SP\&S Railroad Bridge & NA & 1,917 \\
\hline 4456521230242 & Willamette River at Salem Railroad Bridge & ODEQ & 1,721 \\
\hline \multicolumn{4}{|c|}{ Nutrients } \\
\hline 4526001220200 & Fox Creek & USFS & 2,993 \\
\hline 14211720 & Willamette River at Portland & USGS & 935 \\
\hline 452481225103 & Tualatin River at Elsner Road Bridge & NA & 864 \\
\hline 14207500 & Tualatin River at West Linn & USGS & 784 \\
\hline 14128910 & Columbia River at Warrendale & USGS & 774 \\
\hline \multicolumn{4}{|c|}{ Trace Elements } \\
\hline 14128910 & Columbia River at Warrendale & USGS & 2,115 \\
\hline 14211720 & Willamette River at Portland & USGS & 1,964 \\
\hline 14207500 & Tualatin River at West Linn & USGS & 1,815 \\
\hline 14247400 & Columbia River at Bradwood & USGS & 763 \\
\hline 4524181225103 & Tualatin River at Elsner Road Bridge & NA & 587 \\
\hline \multicolumn{4}{|c|}{ Organic Compounds } \\
\hline 14202000 & Pudding River at Aurora & USGS & 4,384 \\
\hline 14201300 & Zollner Creek near Mt. Angel & USGS & 4,228 \\
\hline 14206950 & Fanno Creek at Durham & USGS & 2,008 \\
\hline 14211720 & Willamette River at Portland & USGS & 1,122 \\
\hline 4431381231209 & Muddy Creek near Peoria & USGS & 800 \\
\hline \multicolumn{4}{|c|}{ Suspended Sediment } \\
\hline 4526001220200 & Fox Creek & USFS & 2,868 \\
\hline 4530001220200 & North Fork Bull Run at RM 0.1 above S-10 & USFS & 2,022 \\
\hline 4529001220100 & Fir Creek at S-111 & USFS & 1,991 \\
\hline 4527001220900 & Bull Run Reservoir at Headworks & USFS, EPA & 1,766 \\
\hline 4530001220000 & Bull Run Main stem/ Bear Creek West Fork & USFS & 1,689 \\
\hline \multicolumn{4}{|c|}{ Bacteria } \\
\hline 14138990 & Bear Creek near Bull Run & USGS & 329 \\
\hline 14138900 & North Fork Bull Run River near Multnomah Falls & USGS & 322 \\
\hline 14138960 & Cougar Creek near Bull Run & USGS & 322 \\
\hline 14138950 & Deer Creek near Bull Run & USGS & 319 \\
\hline 14138850 & Bull Run River near Multnomah Falls & USGS & 316 \\
\hline 14139800 & South Fork Bull Run River near Bull Run & USGS & 316 \\
\hline
\end{tabular}




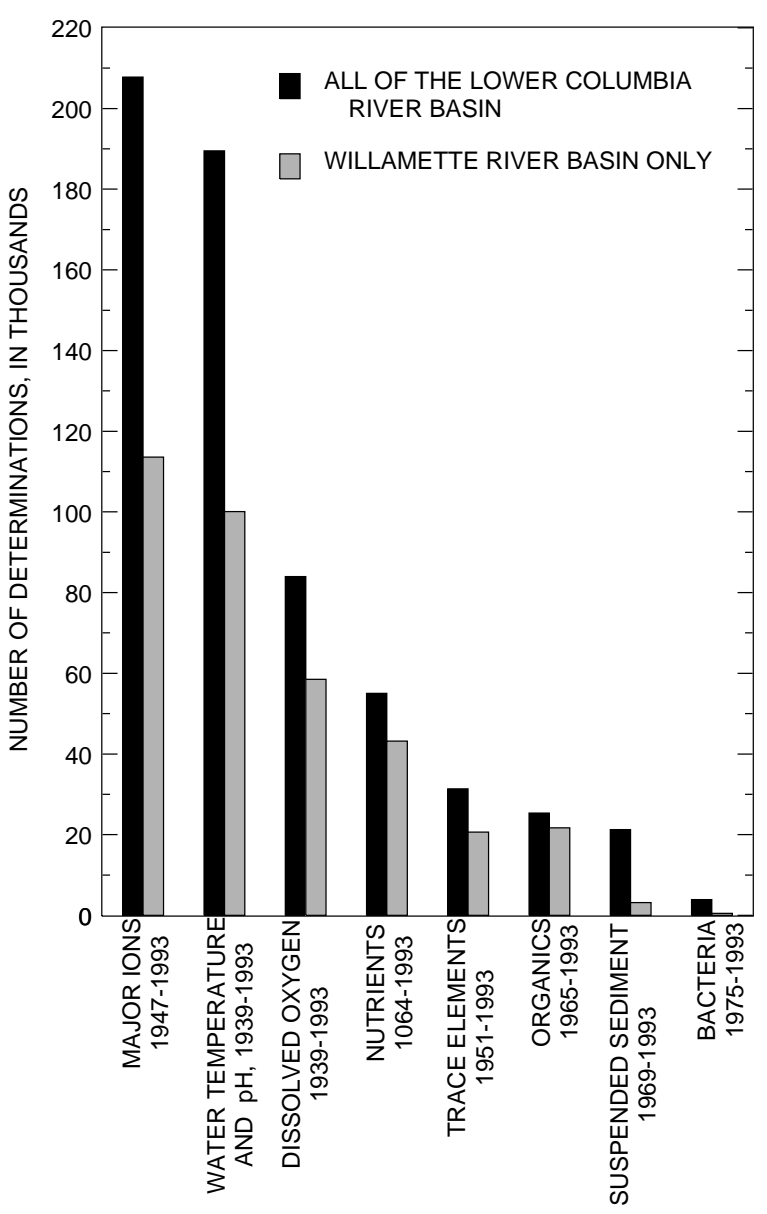

CONSTITUENT GROUP AND YEARS OF RECORD

Figure 13. Number of historical surface-water-quality determinations by constituent group, lower Columbia River Basin, Oregon and Washington, 1939-93. (Sources of data: U.S. Environmental Protection Agency's STOrage and RETrieval System; U.S. Geological Survey's National Water Inventory System; Tetra Tech, Inc., 1993; and Tetra Tech, Inc., Redmond, Washington, unpub. data, 1994.)

The major ions, water temperature and $\mathrm{pH}$, dissolved oxygen, and nutrient groups had the largest number of determinations, probably because these constituents (1) are the least costly to determine, (2) can provide a good preliminary indication of water-quality conditions, (3) are associated with other water-quality concerns, and (4) have methods of determination (with appropriate reporting limits) that have been available for the last couple of decades. In contrast, the potentially toxic constituent groups, including the trace elements and organic compounds, have fewer determinations, primarily due to the high costs of determination and shorter periods of record.

\section{Current Data}

The USGS, WDOE, and ODEQ collected data in the lower Columbia River Basin for the Bi-State ambient-monitoring program from January to December 1994 (table 7). All USGS data from this study are published in the U.S. Geological Survey Water Resources Data Report for Oregon for the 1994 water year (U.S Geological Survey, 1995). USGS data also are available in the NWIS database. All data for this study collected by the USGS, WDOE, and ODEQ will be stored in EPA's STORET database.

\section{U.S. Geological Survey}

Ten sites were sampled by the USGS in 1994 (fig. 14). The location of each site was determined by comparing landmarks in the field to $7-1 / 2$ minute series topographic maps (scale 1:24,000). At every sampling, field measurements (dissolved oxygen, $\mathrm{pH}$, water temperature, alkalinity, and specific conductance) were made and samples were collected for determination of major ions, nutrients, suspended sediment (concentration and percent finer than $63 \mu \mathrm{m}$ [micrometers]), fecal-indicator bacteria, and chlorophyll. At each of the 10 sites, 4 samplings were made for trace elements and organic compounds. Analyses included measurements of trace elements in filtered water and in suspended sediment, organic compounds in filtered water ${ }^{4}$, and organic carbon in filtered water and associated with suspended sediment. Sample collection dates were not based on hydrologic events, but were scheduled in advance, as is consistent with a basic monitoring program. Additional samplings for organic compounds were made at the Willamette River as part of the USGS Willamette NAWQA and Willamette State Study sampling program. Six of the 10 sites were sampled monthly by boat: the 4 Columbia River sites, the Willamette River at Portland, and Multnomah Channel near mouth. Tide tables were consulted at tidally affected sites to facilitate sampling during ebb tides and to insure that samples represented water-quality conditions upstream. The other four sites (the Sandy River,

\footnotetext{
${ }^{4}$ The term "filtered water" is an operational definition referring to the chemical analysis of that portion of a water-suspended sediment sample that passes through a nominal $0.45-\mu \mathrm{m}(0.70-\mu \mathrm{m}$ for organic compounds) filter. The term "unfiltered water" refers to the chemical analysis of a water sample that has not been filtered or centrifuged, nor in any way altered from the original matrix.
} 
Table 7. Sampling sites and constituents analyzed, lower Columbia River Basin, Oregon and Washington, 1994

[USGS, U.S. Geological Survey; ODEQ, Oregon Department of Environmental Quality; WDOE, Washington Department of Ecology; NA, not applicable; SS, suspended sediment; B, fecal-indicator bacteria; $\mathrm{Ch}$, chlorophyll; TSS, total suspended solids; sites may be referred to by their abbreviated name in this report]

\begin{tabular}{|c|c|c|c|c|c|c|c|c|c|}
\hline \multirow[b]{2}{*}{$\begin{array}{l}\text { Agency } \\
\text { site } \\
\text { number }\end{array}$} & \multirow[b]{2}{*}{$\begin{array}{l}\text { Site name } \\
\text { (abbreviated site name) }\end{array}$} & \multirow[b]{2}{*}{ Agency } & \multicolumn{2}{|c|}{ River mile } & \multicolumn{4}{|c|}{ Number of samples } & \multirow[b]{2}{*}{$\begin{array}{l}\text { Other } \\
\text { constituents } \\
\text { sampled }\end{array}$} \\
\hline & & & Columbia & Tributary & $\begin{array}{l}\text { Field } \\
\text { values }\end{array}$ & $\begin{array}{l}\text { Major } \\
\text { ions }\end{array}$ & Nutrients & $\begin{array}{l}\text { Trace } \\
\text { elements } \\
\text { and organic } \\
\text { compounds }\end{array}$ & \\
\hline 14128910 & $\begin{array}{l}\text { Columbia River at Warrendale, Oregon } \\
\text { (Warrendale) }\end{array}$ & USGS & 141.0 & NA & 11 & 11 & 11 & 4 & $\mathrm{SS}, \mathrm{B}, \mathrm{Ch}$ \\
\hline $\begin{array}{l}453056 \\
122213701\end{array}$ & $\begin{array}{l}\text { Sandy River near Troutdale, Oregon } \\
\text { (Sandy River) }\end{array}$ & USGS & 120.5 & 5.8 & 4 & 4 & 4 & 4 & $\mathrm{SS}, \mathrm{B}, \mathrm{Ch}$ \\
\hline 402351 & Sandy River at Troutdale, Oregon & ODEQ & 120.5 & 3.1 & 13 & 0 & 13 & 0 & B \\
\hline 14144710 & $\begin{array}{l}\text { Columbia River at river mile 102, downstream of Hayden } \\
\text { Island, Oregon } \\
\text { (Hayden Island) }\end{array}$ & USGS & 102.0 & NA & 14 & 13 & 13 & 4 & $\mathrm{SS}, \mathrm{B}, \mathrm{Ch}$ \\
\hline 14211720 & $\begin{array}{l}\text { Willamette River at Portland, Oregon } \\
\text { (Willamette River) }\end{array}$ & USGS & 101.5 & 12.8 & 14 & 14 & 14 & 6 & $\mathrm{SS}, \mathrm{B}, \mathrm{Ch}$ \\
\hline 402288 & Willamette River at Hawthorne Bridge, Oregon & ODEQ & 101.5 & 13.2 & 14 & 14 & 14 & 0 & $\mathrm{~B}$ \\
\hline $\begin{array}{l}455417 \\
122441000\end{array}$ & $\begin{array}{l}\text { Lewis River at Woodland, Washington } \\
\text { (Lewis River) }\end{array}$ & USGS & 87.0 & 5.7 & 4 & 4 & 4 & 4 & $\mathrm{SS}, \mathrm{B}, \mathrm{Ch}$ \\
\hline $27 \mathrm{C} 070$ & Lewis River at Woodland, Washington & WDOE & 87.0 & 5.7 & 12 & 0 & 12 & 0 & TSS, B \\
\hline 14222850 & $\begin{array}{l}\text { Multnomah Channel near mouth, at St. Helens, Oregon } \\
\text { (Multnomah Channel) }\end{array}$ & USGS & 86.3 & .9 & 12 & 12 & 12 & 4 & $\mathrm{SS}, \mathrm{B}, \mathrm{Ch}$ \\
\hline 14222890 & $\begin{array}{l}\text { Columbia River near Columbia City, Oregon } \\
\text { (Columbia City) }\end{array}$ & USGS & 82.4 & NA & 12 & 12 & 12 & 4 & $\mathrm{SS}, \mathrm{B}, \mathrm{Ch}$ \\
\hline 14223600 & $\begin{array}{l}\text { Kalama River above Spencer Creek, near Kalama, } \\
\text { Washington } \\
\text { (Kalama River) }\end{array}$ & USGS & 73.1 & 2.8 & 4 & 4 & 4 & 4 & $\mathrm{SS}, \mathrm{B}, \mathrm{Ch}$ \\
\hline 27B070 & Kalama River near Kalama, Washington & WDOE & 73.1 & 2.8 & 12 & 0 & 12 & 0 & TSS, B \\
\hline 14244200 & $\begin{array}{l}\text { Cowlitz River at Kelso, Washington } \\
\text { (Cowlitz River) }\end{array}$ & USGS & 68.0 & 4.8 & 4 & 4 & 4 & 4 & $\mathrm{SS}, \mathrm{B}, \mathrm{Ch}$ \\
\hline 26B070 & Cowlitz River at Kelso, Washington & WDOE & 68.0 & 4.8 & 12 & 0 & 12 & 0 & TSS, B \\
\hline 14246900 & $\begin{array}{l}\text { Columbia River at Beaver Army Terminal near Quincy, } \\
\text { Oregon } \\
\text { (Beaver Army Terminal or Beaver) }\end{array}$ & USGS & 53.8 & NA & 16 & 17 & 16 & 4 & $\mathrm{SS}, \mathrm{B}, \mathrm{Ch}$ \\
\hline
\end{tabular}




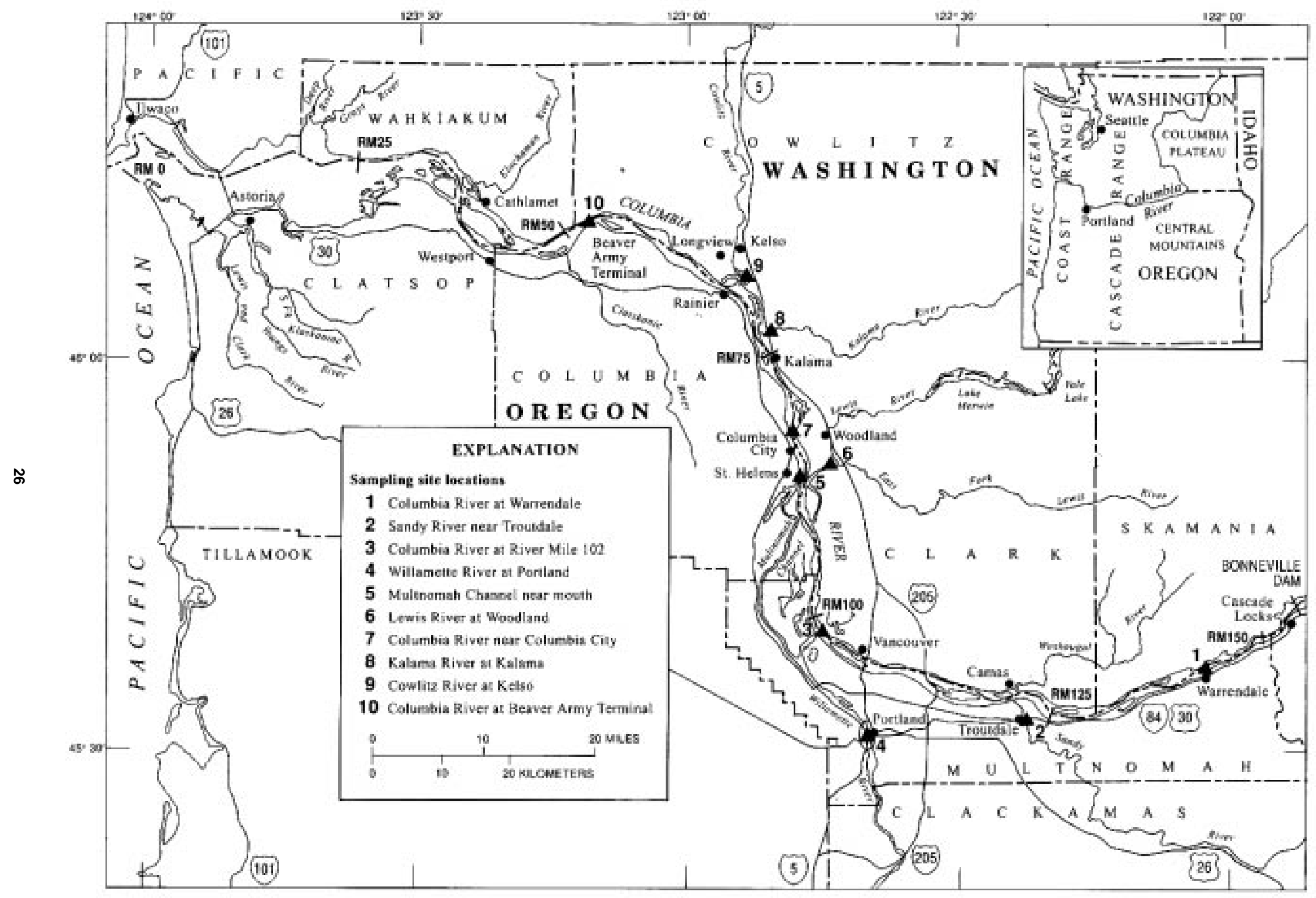

Figure 14. Map showing U.S. Geological Survey sampling locations, lower Columbia River Basin, Oregon and Washington, 1994. 
Lewis River, Kalama River, and Cowlitz River) were sampled from bridges; each sites was sampled four times during 1994.

Sampling techniques described by Edwards and Glysson (1988) were used to insure that the sample was representative of the flow in the cross section. Samples were obtained either at equal spacing across the cross section (equal-widthincrement method), or at the centroids of equaldischarge increments (equal-discharge-increment method). Samples were collected by using a weighted sampler designed to fill with water isokinetically (at the same rate as the flow velocity of the river). The sampler was lowered to the river bed (up to 80 feet deep) and raised by using a variable-speed power-operated winch. For the boat sites, an 8-liter (L) collapsible Teflon-bag sampler with Teflon cap and nozzle (C.F. Nordin, U.S. Geological Survey, written commun., 1981) was used following the procedures outlined by Meade and Stevens (1990) and Horowitz and others (1994). Alternatively, an epoxy-coated aluminum sampler (the D-77 depth-integrating sampler), which contained a 3-L Teflon bottle with Teflon cap and nozzle, was used at the bridge sites. Samples for bacterial analysis were collected from the midchannel section by using an autoclaved plastic bag in the sampler and a sterilized cap and nozzle. Field measurements were made by using a portable probe unit at a depth of 1 meter at 10 locations along the cross section. These measurements were recorded as the arithmetic mean of the 10 measurements. At the Columbia River sites, total dissolved gas was measured in June and July by using a Weiss saturometer.

The parts-per-billion protocol described by Horowitz and others (1994) was followed for the collection of samples for trace-element analysis of filtered water. This procedure involves acid rinsing or acid soaking the sampler and sample containers and the use of latex gloves by a person who touches only the sampler. Samples for trace elements, major ions, nutrients, suspended sediment, and chlorophyll were transferred from the sampler to a $14 \mathrm{~L}$ polyethylene churn splitter. Samples for organic compounds were transferred to a $10 \mathrm{~L}$ glass carboy, and samples for trace elements in suspended sediment were transferred to $10 \mathrm{~L}$ polycarbonate carboys. Bacteria samples were transferred to sterilized glass bottles. All samples were chilled immediately in the field, except for suspended traceelement samples for which the large volume (up to 120 L) made immediate chilling impractical. Large sample volumes were needed for suspended traceelements, because the suspended sediment concentration in the Columbia River was often as low as 5 to $10 \mathrm{mg} / \mathrm{L}$. On a monthly basis, quality assurance samples were included with routine waterquality samples to quantify accuracy, precision, presence of laboratory contamination, and analytical bias. The quality assurance program consisted of source solution blanks, field equipment blanks, split samples, standard reference samples, and for organic compounds only, field matrix spikes and surrogate spikes. Results of the quality assurance programs are included in the quality assurance section at the end of this report.

Equipment used for sampling and processing was washed with Liquinox, rinsed with hot tap water, once with 5-percent (by volume) hydrochloric acid, and three times with distilled/deionized water. The Teflon sample bottles and the filtration unit used for organic compounds also were rinsed with methanol and allowed to air dry. The organic-carbon filtration unit was instead rinsed with organic-free blank water. All sampling equipment was rinsed in ambient stream water prior to sample collection.

At the USGS laboratory in Portland, water samples were processed immediately and prepared for laboratory analysis. The churn splitter was used to resuspend the water/sediment mixture prior to subsampling for unfiltered-water determinations. Before filtered-water samples were processed, some of the water-suspended sediment mixture was withdrawn from the churn splitter into a graduated cylinder for organic-carbon analysis. The mixture was filtered through a $47-\mathrm{mm}$ (millimeter) diameter, $0.45-\mu \mathrm{m}$ pore-size silver filter. The filtrate for analysis of organic carbon in filtered water was collected in a $125-\mathrm{mL}$ (milliliter) glass bottle with a Teflon lid-liner. The silver filter was removed from the filter assembly and placed in a petri dish for the analysis of organic carbon associated with suspended sediment. A portion of the water remaining in the churn splitter was filtered through a $0.45-\mu \mathrm{m}$ pore-size capsule filter and dispensed into the corresponding sample bottles for filtered-water determinations. Filtered-water samples for trace elements were preserved with ultrapure nitric acid according to Horowitz and others (1994). Filtered- 
water samples for mercury were preserved with nitric acid/potassium dichromate. Nutrient samples were preserved with mercuric chloride. The samples for organic compounds were filtered through a 142-mm diameter, $0.7-\mu \mathrm{m}$ pore-size glass-fiber filter that had been baked to remove the organic carbon. These filtered samples then were pumped through solid-phase extraction cartridges, which were submitted for analysis. All samples were shipped on ice to the USGS National Water Quality Laboratory (NWQL) in Denver, Colorado.

The samples for trace elements in suspended sediment were refrigerated at $4{ }^{\circ} \mathrm{C}$ on arrival at the Portland laboratory. Within 1 week of collection, the samples were brought to room temperature and centrifuged to concentrate the suspended sediment. Centrifuge speed and spin times were adequate to remove $0.45-\mu \mathrm{m}$ diameter or larger particlesassuming a particle density of 2.5 grams per cubic centimeter. Each sample was rinsed in approximately $250 \mathrm{~mL}$ of distilled/deionized water during the final centrifugation steps. Final sample concentrates were placed in the oven at room temperature until dry. The dried samples were shipped to the USGS Analytical Chemistry Services Group in Denver, Colorado, for analysis.

Bacteria samples were analyzed by membranefiltration methods according to Britton and Greeson (1987) and the American Public Health Association and others (1989) at the USGS's Portland laboratory. Chlorophyll samples were analyzed using fluorometry (American Public Health Association and others, 1989) at the USGS's Portland laboratory. Samples for suspendedsediment concentration and size class were analyzed at the USGS laboratory in Vancouver, Washington, using the methods in Guy (1969).

Table 8 lists the major ions, nutrients, organic carbon, and trace elements determined at the USGS National Water Quality Laboratory. Water samples were analyzed for major ions according to methods of Fishman (1993) and Fishman and Friedman (1989). Nutrients were analyzed according to methods of Fishman (1993), Kim Pirkey, (USGS, written commun., 1995), and Patton and Truitt (1992). Organic carbon was analyzed according to the methods described in Brenton and Arnett (1993), and Wershaw and others (1987). Filteredwater samples for all trace elements except arsenic, selenium, and mercury were analyzed by inductively coupled plasma-mass spectrometry as described in Faires (1993). Arsenic and selenium were analyzed by hydride generation-atomic absorption spectrometry, and mercury was analyzed by cold vapor-atomic absorption spectrometry (Fishman and Friedman, 1989).

The method reporting limits (MRL's) shown in table 8 are based on reliable quantification, given various sample compositions. The purpose of using MRL's rather that method detection limits is to minimize the problems associated with field and laboratory contamination and to ensure a high degree of confidence in analytical results from a routine mode of operation. For trace elements in filtered water, the MRL's are approximately five times greater than the average-determined method detection limit (Faires, 1993).

Organic compounds in filtered water were analyzed at the NWQL by gas chromatography/mass spectrometry after eluting the analytes from the C18 solid-phase extraction cartridge as described by Zaugg and others (1995). Table 9 lists the 47 organic compounds analyzed using this method (schedule 2010). The method detection limits (MDL) for schedule 2010 are listed in table 9. The MDL's represent the minimum analyte concentration present in a sample with a given composition containing the analyte that can be identified, measured, and reported with 99-percent confidence that the analyte concentration is greater that zero.

In addition to determinations of the 47 organic compounds listed above, a second group of 42 organic compounds was analyzed by using highperformance liquid-chromatography/ultraviolet spectrometry. Quality assurance for this new method (designated by the USGS as schedule 2051) is under review by the USGS's Methods Development Group. The USGS is reviewing analytical-method performance issues related to sample preservation/ sample degradation, potential for saturation of the Carbopak solid-phase adsorbent cartridge and subsequent loss of analyte prior to analysis, lapsed time between sample extraction from the solid-phase cartridge and sample analysis, potential for coelution of analytes, and concerns regarding false negatives. All of these factors ultimately affect the quality of the reported organic-compound concentrations. Consequently, schedule 2051 data were unavailable for use in this study 
Table 8. Method reporting limits for major ions, nutrients, organic carbon, and trace elements analyzed in filtered and unfiltered water, lower Columbia River Basin, Oregon and Washington, 1994

[Values are reported in milligrams per liter, except for trace elements which are reported in micrograms per liter; STORET, U.S. Environmental Protection Agency's STOrage and RETrieval system; method reference numbers correspond to:
a. Fishman, 1993,
d. Patton and Truitt, 1992,
b. Fishman and Friedman, 1989,
e. Brenton and Arnett, 1993,
c. Kim Pirkey, U.S. Geological Survey National Water Quality
f. Wershaw and others, 1987, and
Laboratory, written commun., 1995
g. Faires, 1993 ]

\begin{tabular}{|c|c|c|c|}
\hline STORET code & Constituent name & Method reference number & Method reporting limit \\
\hline \multicolumn{4}{|c|}{ Major ions in filtered water } \\
\hline 00915 & Calcium & a. I-1472-87 & 0.02 \\
\hline 00940 & Chloride & b. I-2057-85 & .1 \\
\hline 00950 & Fluoride & b. I-2057-85 & .1 \\
\hline 01046 & Iron & a. I-1472-87 & .003 \\
\hline 00925 & Magnesium & a. I-1472-87 & .01 \\
\hline 00935 & Potassium & b. I-1630-85 & .1 \\
\hline 00955 & Silica & a. I-1472-87 & .01 \\
\hline 00930 & Sodium & a. I-1472-87 & .2 \\
\hline 00945 & Sulfate & b. I-2057-85 & .1 \\
\hline 70300 & Total dissolved solids & b. I- $1750-85$ & 1 \\
\hline \multicolumn{4}{|c|}{ Nutrients in water } \\
\hline 00608 & Ammonia as $\mathrm{N}$, filtered water & a. I-2522-90 & .01 \\
\hline 00623 & Ammonia plus organic nitrogen as $\mathrm{N}$, filtered water & c. I-2515-91 & .2 \\
\hline 00625 & Ammonia plus organic nitrogen as $\mathrm{N}$, unfiltered water & c. I-4515-91 & .2 \\
\hline 00613 & Nitrite as $\mathrm{N}$, filtered water & a. I-2540-90 & .01 \\
\hline 00631 & Nitrite plus nitrate as $\mathrm{N}$, filtered water & a. I-2545-90 & .05 \\
\hline 00671 & Orthophosphate as $\mathrm{P}$, filtered water & a. I-2601-90 & .001 \\
\hline 00666 & Phosphorus as $\mathrm{P}$, filtered water & d. I-2610-91 & .01 \\
\hline 00665 & Phosphorus as P, unfiltered water & d. I-4610-91 & .01 \\
\hline \multicolumn{4}{|c|}{ Organic carbon in water } \\
\hline 00681 & Organic carbon, filtered water & e. O-1122-92 & .1 \\
\hline 00689 & Organic carbon, associated with suspended sediment & f. $O-7100-83$ & .1 \\
\hline \multicolumn{4}{|c|}{ Trace elements in filtered water } \\
\hline 01106 & Aluminum & g. I-2477-92 & 1 \\
\hline 01095 & Antimony & g. I-2477-92 & 1 \\
\hline 01000 & Arsenic & b. I-2062-85 & 1 \\
\hline 01005 & Barium & g. I-2477-92 & 1 \\
\hline 01010 & Beryllium & g. I-2477-92 & 1 \\
\hline 01025 & Cadmium & g. I-2477-92 & 1 \\
\hline 01030 & Chromium & g. I-2477-92 & 1 \\
\hline 01035 & Cobalt & g. I-2477-92 & 1 \\
\hline 01040 & Copper & g. I-2477-92 & 1 \\
\hline 01049 & Lead & g. I-2477-92 & 1 \\
\hline 01056 & Manganese & g. I-2477-92 & 1 \\
\hline 71890 & Mercury & b. I-2462-85 & .1 \\
\hline 01060 & Molybdenum & g. I-2477-92 & 1 \\
\hline 01065 & Nickel & g. I-2477-92 & 1 \\
\hline 01145 & Selenium & b. I-2667-85 & 1 \\
\hline 01075 & Silver & g. I-2477-92 & 1 \\
\hline 22703 & Uranium & g. I-2477-92 & 1 \\
\hline 01090 & Zinc & g. I-2477-92 & 1 \\
\hline
\end{tabular}


Table 9. Method detection limits for organic compounds analyzed in filtered water, lower Columbia River Basin, Oregon and Washington, 1994

[The term "filtered water" is an operational definition referring to the chemical analysis of that portion of a water-suspended sediment sample that passes through a nominal 0.70-micrometer filter; values are reported in micrograms per liter; STORET, U.S. Environmental Protection Agency's STOrage and RETrieval system; DCPA, 3',4'-dichloropropionanilide; DDE, dichlorodiphenyldichloroethylene; EPTC, S-ethyl dipropyl thiocarbamate; HCH, hexachlorocyclohexane; method discussed in Zaugg and others, 1995]

\begin{tabular}{|c|c|c|c|}
\hline STORET code & Compound name & $\begin{array}{c}\text { Chemical Abstracts Services } \\
\text { registry number }\end{array}$ & Method detection limit \\
\hline 49260 & Acetochlor & $34256-82-1$ & 0.009 \\
\hline 46342 & Alachlor & $15972-60-8$ & .002 \\
\hline 39632 & Atrazine & $1912-24-9$ & .001 \\
\hline 82686 & Azinphos-methyl & $86-50-0$ & .001 \\
\hline 82673 & Benfluralin & $1861-40-1$ & .002 \\
\hline 04028 & Butylate & $2008-41-5$ & .002 \\
\hline 82680 & Carbaryl & $63-25-2$ & .003 \\
\hline 82674 & Carbofuran & $1563-66-2$ & .003 \\
\hline 38933 & Chlorpyrifos & $2921-88-2$ & .004 \\
\hline 04041 & Cyanazine & $21725-46-2$ & .004 \\
\hline 82682 & DCPA & $1861-32-1$ & .002 \\
\hline 34653 & 4,4'-DDE & $72-55-9$ & .006 \\
\hline 04040 & Deethylatrazine & $6190-65-4$ & .002 \\
\hline 39572 & Diazinon & $333-41-5$ & .002 \\
\hline 39381 & Dieldrin & $60-57-1$ & .001 \\
\hline 82660 & 2,6-Diethylaniline & $91-66-7$ & .003 \\
\hline 82677 & Disulfoton & 298-04-4 & .017 \\
\hline 82668 & EPTC & $759-94-4$ & .002 \\
\hline 82663 & Ethalfluralin & $55283-68-6$ & .004 \\
\hline 82672 & Ethoprop & $13194-48-4$ & .003 \\
\hline 04095 & Fonofos & $944-22-9$ & .003 \\
\hline 34253 & alpha-HCH & $319-84-6$ & .002 \\
\hline 39341 & gamma-HCH (lindane) & $58-89-9$ & .004 \\
\hline 82666 & Linuron & $330-55-2$ & .002 \\
\hline 39532 & Malathion & $121-75-5$ & .005 \\
\hline 82667 & Methyl parathion & $298-00-0$ & .006 \\
\hline 39415 & Metolachlor & $51218-45-2$ & .002 \\
\hline 82630 & Metribuzin & $21087-64-9$ & .004 \\
\hline 82671 & Molinate & $2212-67-1$ & .004 \\
\hline 82684 & Napropamide & $15299-99-7$ & .003 \\
\hline 39542 & Parathion & $56-38-2$ & .004 \\
\hline 82669 & Pebulate & $1114-71-2$ & .004 \\
\hline 82683 & Pendimethalin & $40487-42-1$ & .004 \\
\hline 82687 & cis-Permethrin & $52645-53-1$ & .005 \\
\hline 82664 & Phorate & $298-02-02$ & .002 \\
\hline 04037 & Prometon & $1610-18-0$ & .003 \\
\hline 82676 & Pronamide & $23950-58-5$ & .018 \\
\hline 04024 & Propachlor & $1918-16-7$ & .007 \\
\hline 82679 & Propanil & $709-98-8$ & .004 \\
\hline 82685 & Propargite & $2312-35-8$ & .013 \\
\hline 04035 & Simazine & $122-34-9$ & .005 \\
\hline 82670 & Tebuthiuron & $34014-18-1$ & .010 \\
\hline 82665 & Terbacil & $5902-51-2$ & .007 \\
\hline 82675 & Terbufos & 13071-79-9 & .007 \\
\hline 82681 & Thiobencarb & $28249-77-6$ & .002 \\
\hline 82678 & Triallate & $2303-17-5$ & .001 \\
\hline 82661 & Trifluralin & $1582-09-8$ & .002 \\
\hline
\end{tabular}


Suspended trace elements were analyzed at the USGS Analytical Chemistry Services Group in Denver for 44 trace elements (table 10). Most of the elements were analyzed by inductively coupled plasma-atomic emission spectrometry following multi-acid sample decomposition (Briggs, 1990). Alternatively, nine elements (antimony, arsenic, cadmium, lead, molybdenum, silver, thallium, thorium, and uranium) were analyzed by inductively coupled plasma-mass spectrometry following multi-acid sample decomposition (Briggs, 1990). Mercury was analyzed by continuous flow cold vapor-atomic absorption spectrometry following sample digestion with nitric acid and sodium dichromate (O'Leary and others, 1990). Selenium was analyzed by hydride generation-atomic absorption spectrometry following multi-acid digestion (Welsch and others, 1990; Crock and Lichte, 1982). About 0.5 grams of suspended sediment was necessary to perform all the analyses. On several occasions, especially in samples from the four smaller tributaries, there was not enough suspended sediment to perform the analyses for mercury and selenium.

\section{Washington Department of Ecology}

From February 1994 to December 1994, the WDOE sampled the following three sites from

Table 10. Method reporting limits for trace elements analyzed in suspended sediment, lower Columbia River Basin, Oregon and Washington, 1994

[Values are reported in micrograms per gram unless otherwise noted; STORET, U.S. Environmental Protection Agency's STOrage and RETrieval system; \%, percent; --, no code available for thallium; methods discussed in Briggs, 1990, O'Leary and others, 1990, Welsch and others, 1990, and Crock and Lichte, 1982]

\begin{tabular}{|c|c|c|c|c|c|}
\hline $\begin{array}{l}\text { STORET } \\
\text { code }\end{array}$ & $\begin{array}{l}\text { Element } \\
\text { name }\end{array}$ & $\begin{array}{c}\text { Method reporting } \\
\text { limit }\end{array}$ & $\begin{array}{l}\text { STORET } \\
\text { code }\end{array}$ & $\begin{array}{c}\text { Element } \\
\text { name }\end{array}$ & $\begin{array}{l}\text { Method reporting } \\
\text { limit }\end{array}$ \\
\hline 30221 & Aluminum & $0.005 \%$ & 29841 & Mercury & 0.02 \\
\hline 29816 & Antimony & .1 & 29843 & $\begin{array}{l}\text { Molybde- } \\
\text { num }\end{array}$ & .1 \\
\hline 29818 & Arsenic & .1 & 35037 & Neodymium & 9 \\
\hline 29820 & Barium & 1 & 29845 & Nickel & 3 \\
\hline 29822 & Beryllium & 1 & 35038 & Niobium & 4 \\
\hline 35030 & Bismuth & 10 & 30292 & Phosphorus & $.005 \%$ \\
\hline 29826 & Cadmium & .1 & 30294 & Potassium & $.01 \%$ \\
\hline 30240 & Calcium & $.005 \%$ & 35039 & Scandium & 2 \\
\hline 35051 & Cerium & 5 & 29847 & Selenium & .2 \\
\hline 29829 & Chromium & 2 & 29850 & Silver & .1 \\
\hline 35031 & Cobalt & 2 & 30304 & Sodium & $.006 \%$ \\
\hline 29832 & Copper & 2 & 35040 & Strontium & 2 \\
\hline 35032 & Europium & 2 & 35042 & Tantalum & 40 \\
\hline 35033 & Gallium & 4 & -- & Thallium & .1 \\
\hline 82170 & Gold & 8 & 35043 & Thorium & 6 \\
\hline 35035 & Holmium & 4 & 35044 & Tin & 5 \\
\hline 30269 & Iron & $.02 \%$ & 30317 & Titanium & $.005 \%$ \\
\hline 35036 & Lanthanum & 2 & 35046 & Uranium & .07 \\
\hline 29836 & Lead & .25 & 29853 & Vanadium & 2 \\
\hline 35050 & Lithium & 2 & 35048 & Ytterbium & 1 \\
\hline 30277 & Magnesium & $.005 \%$ & 35047 & Yttrium & 2 \\
\hline 29839 & Manganese & 4 & 29855 & Zinc & 2 \\
\hline
\end{tabular}


bridges about once a month: the Lewis River at Woodland, Kalama River near Kalama, and Cowlitz River at Kelso (table 7). Each site that the WDOE sampled was at exactly the same location as the corresponding USGS site. Temperature and specific conductance were measured by lowering a probe into the main channel, whereas measurements of $\mathrm{pH}$ and dissolved oxygen were made on a near-surface grab sample of water. Depth- and width-integrated water samples were collected by lowering a US DH59 depth-integrating sampler at 10 equidistant points along a transect across the river (Edwards and Glysson, 1988). Each volume of water collected was composited into an acid-washed Nalgene container and agitated before individual subsamples were poured into containers prepared for each particular analysis. Water for nutrient analysis was filtered in the field through a 0.45 -micrometer membrane filter (Bill Ehinger, WDOE, written commun., 1995). The samples were shipped to WDOE Environmental Laboratory in Manchester,
Washington, where they were analyzed for nutrients, suspended solids, and fecal-indicator bacteria (table 11).

\section{Oregon Department of Environmental Quality}

From January 1994 to December 1994, the ODEQ sampled the Willamette River and the Sandy River each month. Even though the ODEQ Willamette River site was 0.4 miles upstream of the USGS site and the ODEQ Sandy River site was 2.7 miles downstream of the USGS site (table 7), data from the corresponding sites were grouped together with USGS data for analysis. The midpoint of each river was sampled from a bridge using a weighted stainless-steel grab sampler. Field measurements were made of dissolved oxygen, $\mathrm{pH}$, water temperature, alkalinity, and specific conductance. Samples were collected and field measurements were made according to ODEQ protocols, and the laboratory analyses were performed in the ODEQ

Table 11. Laboratory analytical methods and reporting limits for Washington Department of Ecology, lower Columbia River Basin, 1994

[Values are reported in micrograms per liter for nutrients, milligrams per liter for solids, and colonies per 100 milliliters for bacteria; STORET, U.S. Environmental Protection Agency's STOrage and RETrieval system; --, not available; information obtained from Bill Ehinger, Washington Department of Ecology; method reference numbers correspond to:

a. U.S. Environmental Protection Agency, 1979,

b. American Public Health Association and others, 1992, and

c. Valderrama, 1981]

\begin{tabular}{|c|c|c|c|c|}
\hline $\begin{array}{l}\text { STORET } \\
\text { code }\end{array}$ & Constituent name & Method of determination & $\begin{array}{l}\text { Method } \\
\text { reference } \\
\text { number }\end{array}$ & $\begin{array}{l}\text { Method } \\
\text { reporting } \\
\text { limit }\end{array}$ \\
\hline \multicolumn{5}{|c|}{ Nutrients in water } \\
\hline 00610 & Ammonia as $\mathrm{N}$, unfiltered water & Automated phenate & $\begin{array}{l}\text { a. } 350.1 \\
\text { b. } 4500-\mathrm{NH} 3 \mathrm{D}\end{array}$ & 10 \\
\hline 00630 & Nitrite plus nitrate as $\mathrm{N}$, unfiltered water & Automated cadmium reduction & $\begin{array}{l}\text { a. } 353.2 \\
\text { b. } 4500-\mathrm{NO} 3 \mathrm{~F}\end{array}$ & 10 \\
\hline 00600 & Nitrogen, unfiltered water & Persulfate digestion, cadmium reduction & c. & 25 \\
\hline 00671 & Orthophosphate as $\mathrm{P}$, filtered water & Ascorbic acid & $\begin{array}{l}\text { a. } 365.3 \\
\text { b. } 4500-\mathrm{PF}\end{array}$ & 10 \\
\hline 00665 & Phosphorus as $\mathrm{P}$, unfiltered water & Persulfate digestion, ascrobic acid & $\begin{array}{l}\text { a. } 365.3 \\
\text { b. } 4500-\mathrm{PF}\end{array}$ & 10 \\
\hline \multicolumn{5}{|c|}{ Solids in water } \\
\hline 00500 & Total dissolved solids, filtered water & -- & $\begin{array}{l}\text { a. } 160.3 \\
\text { b. } 2540 \mathrm{~B}\end{array}$ & 1 \\
\hline 00530 & Suspended solids, unfiltered water & Gravimetric & a. 160.1 & 1 \\
\hline \multicolumn{5}{|c|}{ Bacteria } \\
\hline 31616 & Fecal coliform & Membrane filter & b. $9222 \mathrm{D}$ & 1 \\
\hline
\end{tabular}


laboratory in Portland, Oregon (Greg Pettit, ODEQ, written commun., 1995).

Samples were analyzed for major ions (Willamette River site only), nutrients, and fecalindicator bacteria. Ammonia plus organic nitrogen in unfiltered water was analyzed by EPA Method 351.2, (U.S. Environmental Protection Agency, 1979), and phosphorus in unfiltered water and orthophosphate in filtered water were analyzed by Part 4500-P (American Public Health Association and others, 1989). Bacteria samples were analyzed by the Oregon Health Division, Office of Public Health Laboratories in Portland. Enterococci were analyzed by the membrane-filtration method, and fecal coliform were measured by the most probable number technique (American Public Health Association and others, 1989).

\section{Data-Analysis Methods}

Two methods of data analysis that require explanation and description are the estimation of loads and the determination of trends over time, which were calculated for several water-quality constituents.

\section{Loads}

In this report, monthly and annual mean daily loads were calculated using a regression model that assumes a linear relationship between the natural $\log$ arithm of concentration $(\log \mathrm{C})$ and the natural $\log$ arithm of streamflow $(\log \mathrm{Q})$. The model was created using the ESTIMATOR program, version 94.06 (Cohn and others, 1992). The ESTIMATOR program regresses $\log \mathrm{C}$ against $\log \mathrm{Q}$ and the sine and cosine of time (in decimal years, adjusted by $2 \pi$, for a yearly cycle) and generates equations for calculating monthly and annual mean daily load estimates. Monthly mean daily loads are the mean of the individual daily mean loads for each month, which the program computes, and annual mean daily loads are the mean of the individual daily mean loads for each year.

The ESTIMATOR program uses a minimum variance unbiased estimator (Cohn and others, 1989), which reduces the bias introduced when transforming load estimates from a log-regression equation (log space) back into arithmetic units (real space). The program also incorporates an adjusted maximum likelihood estimator (Cohn, Gilroy, and Baier, 1992) to deal with censored data values, which are values that are below a specified "detection limit." The ESTIMATOR program is ideal for use in hydrologic studies, because water quality data generally show a log-log relation and commonly contain censored data. The ESTIMATOR program is widely used by the USGS, including the 35 current NAWQA studies. It is also used by the Maryland Department of the Environment on its Chesapeake Bay projects, and by the U.S. Army Corps of Engineers.

The ESTIMATOR program is recommended for use with at least 25 water-quality measurements per year for 2 years. The Columbia River at Warrendale and the Willamette River at Portland both had about 8 measurements per year for about 20 years, and the Columbia River at Beaver Army Terminal had 12 measurements per year for 4 years. Although these sites had fewer than recommended measurements per year, the periods of available data are longer than recommended. The Willamette and Warrendale sites had much more than the 50 total recommended measurements, and Beaver had nearly 50. No other sites in this study had data points in even close to these numbers. Loads were estimated for five constituents (suspended sediment, total dissolved solids, phosphorus in unfiltered water, nitrite plus nitrate in filtered water, and ammonia in filtered water) sampled at these three sites. Samples generally were collected at different seasons of the year, rather than clustered during short periods of time. See table 12 for the number of data values available for each constituent at each site.

The ESTIMATOR program uses daily mean streamflow data throughout the load computation period. Streamflow data for the Willamette and Beaver sites are available from the USGS streamflow gaging program. Because the Warrendale site is not gaged, data for daily mean outflow from Bonneville Dam, 5 miles upstream, were obtained from the U.S. Army Corps of Engineers and used as daily mean flow at Warrendale. Three water years $(1974,1975$, and 1977) were chosen from the 20-year load estimation period to represent years of high-, median-, and low-streamflow, respectively, based on annual mean streamflows at the Columbia River at mouth streamflow-gaging station. These years are used to compare loads of the current year (1994) to low-, median-, and high-flow years in the past. 
Table 12. Amount of water quality data available for load estimation program, and mean 95-percent confidence intervals for load estimates at three sites in the lower Columbia River Basin, Oregon and Washington

[The term "filtered water" is an operational definition referring to the chemical analysis of that portion of a water-suspended sediment sample that passes through a nominal 0.45 -micrometer filter; conversely, the term "unfiltered water" refers to the chemical analysis of a water sample that has not been filtered or centrifuged, nor in any way altered from the original matrix; see table 7 for full site names]

\begin{tabular}{|c|c|c|c|c|c|}
\hline Site name & $\begin{array}{l}\text { Years of data } \\
\text { available }\end{array}$ & $\begin{array}{l}\text { Total number of } \\
\text { samples }\end{array}$ & $\begin{array}{l}\text { Number of } \\
\text { censored } \\
\text { values }\end{array}$ & $\begin{array}{l}\text { Mean 95-percent } \\
\text { confidence interval } \\
\text { for monthly } \\
\text { estimates } \\
\text { (percent of } \\
\text { estimate) }\end{array}$ & $\begin{array}{l}\text { Mean 95-percent } \\
\text { confidence interval } \\
\text { for annual } \\
\text { estimates } \\
\text { (percent of } \\
\text { estimate) }\end{array}$ \\
\hline \multicolumn{6}{|c|}{ Ammonia, filtered water } \\
\hline Willamette & $1979-94$ & 111 & 0 & 31 & 16 \\
\hline Warrendale & 1973-94 & 80 & 14 & 63 & 33 \\
\hline Beaver & 1990-94 & 49 & 7 & 43 & 24 \\
\hline \multicolumn{6}{|c|}{ Nitrite plus nitrate, filtered water } \\
\hline Willamette & $1979-94$ & 115 & 0 & 20 & 12 \\
\hline Warrendale & 1979-94 & 86 & 22 & 29 & 16 \\
\hline Beaver & 1990-94 & 49 & 8 & 51 & 36 \\
\hline \multicolumn{6}{|c|}{ Phosphorus, unfiltered water } \\
\hline Willamette & $1974-94$ & 173 & 0 & 18 & 9 \\
\hline Warrendale & 1973-94 & 172 & 3 & 30 & 14 \\
\hline Beaver & 1990-94 & 48 & 3 & 38 & 20 \\
\hline \multicolumn{6}{|c|}{ Suspended sediment } \\
\hline Willamette & $1974-94$ & 167 & 0 & 28 & 17 \\
\hline Warrendale & 1973-94 & 164 & 0 & 44 & 21 \\
\hline Beaver & 1990-94 & 49 & 0 & 24 & 12 \\
\hline \multicolumn{6}{|c|}{ Total dissolved solids, residue on evaporation at 180 degrees Celsius } \\
\hline Willamette & $1974-94$ & 171 & 0 & 4 & 2 \\
\hline Warrendale & 1973-94 & 155 & 0 & 5 & 2 \\
\hline Beaver & $1990-94$ & 49 & 0 & 7 & 4 \\
\hline
\end{tabular}

Although the loads estimated by this regression model are believed to be the best estimates given the available data sets, their precision deserves some discussion. For each load estimate, the ESTIMATOR program calculates the standard error of prediction, from which a 95percent confidence interval can be derived. As an example, if a load estimate of 200 tons per day has a 95-percent confidence interval of 20 percent, then there is a 95 percent chance that the true load was between 160 and 240 tons per day (200 \pm 20 percent). Confidence intervals for annual mean daily load estimates tended to be about one-half as wide as intervals for monthly estimates. Table 12 shows the average 95-percent confidence intervals for monthly and annual load estimates from the ESTIMATOR program. The load estimates are most reliable for total dissolved solids and less reliable for other constituents (table 12). These differences are due to the differing degrees by which the constituent characteristics satisfy the assumptions of the regression model, particularly the linear relation between $\log \mathrm{C}$ and $\log \mathrm{Q}$. The sampling strategy itself also affects the confidence intervals, because it was not designed to ensure sampling during peak flows. If more samples had been taken during higher flows, the confidence intervals would probably have been narrower.

\section{Trends}

A computer program called PT2 (Kenneth Lanfear, USGS, written commun., 1995) was used to determine monotonic-time trends in constituent concentrations in the lower Columbia River Basin. This program uses the seasonal Kendall test for water-quality trends (see Helsel and Hirsch [1992] for a description of the test). This distribution-free 
test (based on the ranking of data values) uses a modified form of Kendall's tau to determine trends.

The seasonal Kendall test involves hypothesis testing for trend detection. The null hypothesis is that the variable of interest (for example, constituent concentration) and its time of observation are independent, which indicates no trend (Smith and others, 1982). The chance of making an error by rejecting the null hypothesis when a trend actually does not exist is measured by the probability level $(\rho)$. For example, if $\rho=0.05$, then there is a 5-percent chance of falsely rejecting the null hypothesis. For this study, trends with a $\rho$ less than or equal to 0.05 were considered statistically significant.

There are two criteria for evaluating the suitability of water-quality data for trend testing. First, the data must have nearly spanned the time period selected for trend analysis. Second, for a given seasonal frequency (trends made on the basis of quarterly data, for instance), the beginning and ending parts of the record must have contained sufficient data such that most of the possible number of pairwise comparisons (as made in the seasonal Kendall test) were present for most of the seasons. Owing to a lack of continuous data for most sites, trend tests were performed only on data from the Columbia River at Warrendale and Willamette River at Portland sites (the two historical NASQAN sites).

Seasonal patterns that may affect results from trend analyses commonly are observed in waterquality data. For example, in the calculation of long-term trends, data collected during an extreme high-flow winter storm should not be compared to data collected during a low-flow summer condition. To minimize erroneous conclusions that could result from these types of comparisons, data collected in the same month of different years are compared (for example, values from January 1993 are compared with those from January 1994). When there are not enough monthly data available, seasonal data can be used. When the later constituent value (in time) is larger, a plus is scored, but when lower, a minus is scored (Smith and others, 1982). Equal numbers of pluses and minuses indicate the absence of a trend. When there are significantly more pluses than minuses, an upward trend in constituent concentration is likely. In this nonparametric test, censored data (values less than the reporting level) were included in the analysis and set equal to the reporting level.

Trends, unadjusted for streamflow, are important because they represent changes in constituent concentrations that may affect water quality and biota. Because monthly data were not available, trend analysis was made using quarterly (SeptemberOctober-November, December-January-February, and so on) constituent concentrations for data collected from 1973 to 1995 . For suspendedsediment data at the Willamette River at Portland, however, there were enough data to use a bimonthly season (September-October, November-December, and so on).

To estimate the magnitude of the trend, a seasonal slope estimator is computed (Hirsch and others, 1982). The slope estimator is the median of the data set containing the differences between data values collected in the same month (or quarter) of different years between the data. For example, assume that the ammonia concentration at a site was $0.1 \mathrm{mg} / \mathrm{L}$ (milligrams per liter) in the first quarter of 1993 and $0.2 \mathrm{mg} / \mathrm{L}$ in the first quarter of 1994. The difference between the values divided by the number of years between the data is $(0.2-0.1) \div(1994-1993)$ $=0.1 \mathrm{mg} / \mathrm{L}$ per year. After computing these differences for each quarter for all combinations of years, the slope (trend) is reported here as the median change in the constituent value per year. The slope (trend) also is reported in percent change per year and is calculated as follows: (slope $\div$ median constituent value) $\times 100$.

Trends in water quality are associated not only with fluctuations in climate and streamflow but also with human-caused changes in basin processes, including land-use practices, point-source loading rates, and agricultural and forestry practices. Flowadjustment procedures were used to determine trends that are associated with changes in basin processes. These procedures deduce a relation between concentration and streamflow and convert concentrations to residual values before performing a trend test on the residual values. This procedure removes the confounding effect of variations in streamflow. PT2 performs flow adjustment with a LOcally WEighted Scatterplot Smoothing (LOWESS) technique (discussed by Helsel and Hirsch [1992]). It is a robust technique that provides a reasonably good fit of concentration versus streamflow for a wide variety of situations. The slope estimator is then 
calculated from the flow-adjusted data to yield the trends.

\section{Existing Water-Quality Guidelines}

Water-quality constituent concentrations determined and physical measurements made in the lower Columbia River Basin in 1994 were screened to identify constituents and measurements that may require further study by State and local health agencies. These agencies are responsible for issuing advice or formal advisories to protect the public health. Major ion, nutrient, trace-element, and organic-compound concentrations in filtered-water samples are screened against EPA ambient waterquality criteria for the protection of aquatic life and human health (U.S. Environmental Protection Agency, 1995) and EPA primary drinking-water regulations and human health advisories (U.S. Environmental Protection Agency, 1994b). All EPA ambient water-quality criteria are nonenforceable guidelines that provide the basis for Oregon and Washington State standards and are designed to protect humans and aquatic organisms. The primary drinking-water regulations have been established for contaminants that are known to be present in public water systems and that may affect human health adversely (Nowell and Resek, 1994). Health advisories provide nonregulatory levels of contaminants in drinking water at which no known or anticipated health effects would result. For some constituents, the analytical detection limit is higher than the lowest water-quality guideline.

Furthermore, guidelines are not available for evaluation of all potential adverse effects (specifically, acute and chronic toxicity to aquatic organisms, human health effects as a result of bioaccumulation in aquatic food organisms, and exposure through drinking water).

Bioavailability and toxicity vary with the form of a trace element (Jenne and Luoma, 1977). Aquatic organisms that feed on detritus are exposed to trace elements in solution and from the ingestion of sediment (Luoma, 1989). Trace elements associated with sediment generally are believed to be less bioavailable than trace elements dissolved in water (U.S. Environmental Protection Agency, 1992a). The toxicity to aquatic organisms from trace elements associated with sediment, however, is not necessarily zero. The concentrations of metals in sediment often are orders of magnitude higher than in water. Small geochemical changes in the chemistry of sediment can affect solution chemistry greatly and thus enhance bioavailability (Luoma, 1989). For example, trace elements associated with suspended sediment may dissolve in the chemical environment of the gill or the gut of an aquatic organism (U.S. Environmental Protection Agency, 1992a; Luoma, 1983).

Physical and microbiological measurements were compared to water-quality regulations of Oregon (State of Oregon, 1994) and Washington (Washington State Administrative Code, 1992). Washington streams are classified according to general beneficial water uses. An antidegradation policy is being used to protect existing water-quality conditions (Washington State Administrative Code, 1992). All of the Washington sites sampled in this study were at stream segments classified as class A (excellent), meaning that they must meet or exceed standards established for all, or substantially all, designated water uses.

\section{Ambient Stream Water Quality}

\section{Aquatic Life}

According to EPA's interim guidance on aquatic-life criteria for trace elements (U.S. Environmental Protection Agency, 1992a), the toxicity tests that form the basis for EPA ambient water-quality criteria for the protection of aquatic life were generally conducted in water "lower in metal-binding particulate matter and dissolved organic carbon than most ambient waters $* * *$. [Therefore], these toxicity tests may overstate the ambient toxicity of nonbiomagnified metals that interact with particulate matter or dissolved organic matter." In metal toxicity tests on which waterquality criteria were based, most of the metal was in the dissolved form. However, because the actual dissolved component was seldom measured in these tests, and because of the possible release of dissolved metal from particulate forms, EPA criteria are based on the total recoverable metal technique. This type of analysis for ambient stream water, with metal-binding phases, may extract trace elements from the particulate or carbon phases, and consequently, overstate ambient toxicity.

Although EPA's ambient water-quality criteria are based on analyses of unfiltered-water samples, 
the trace-element concentrations in filtered-water samples analyzed for this report were often high enough to equal or exceed the criteria.

Consequently, EPA's ambient water-quality criteria are used as screening values for the protection of aquatic organisms. For many trace elements, including cadmium, chromium, lead, nickel, silver, and zinc, aquatic toxicity is related to the hardness of the water; toxicity increases (the screening value decreases) as hardness decreases. For example, as water hardness ranges from 200 to $50 \mathrm{mg} / \mathrm{L}$ (milligrams per liter) as calcium carbonate, lead toxicity to aquatic organisms ranges from 7.7 to $1.3 \mu \mathrm{g} / \mathrm{L}$ (micrograms per liter) (U.S. Environmental Protection Agency, 1986a). For trace elements with toxicity that varies with water hardness, the ambient water hardness at the time of sample collection was used to derive the appropriate screening value. Both acute (1-hour average concentrations) and chronic (4-day average concentrations) trace-element criteria for aquatic life were used to evaluate waters in the lower Columbia River Basin; however, single measurements, rather than multiple measurements were used to derive 1-hour or 4-day average traceelement concentrations.

\section{Human Health}

The ambient stream-water criteria for the protection of human health consist of ambient concentrations which, for noncarcinogens, prevent adverse health effects in humans and, for suspected or proven carcinogens, represent various levels of incremental cancer risk. The human-health criteria are designed to reflect human exposure to a contaminant from ingestion of both water and aquatic organisms or from ingestion of aquatic organisms only (U.S. Environmental Protection Agency, 1995). In the former, 100 percent of the exposure to humans is assumed to be from consumption of water containing a specified contaminant concentration and aquatic organisms that have biologically concentrated a contaminant from ambient stream water according to an assumed biological concentration factor (Nowell and Resek, 1994; U.S. Environmental Protection Agency, 1995). In the latter, 100 percent of the exposure to humans is assumed to be from consumption of aquatic organisms that have biologically concentrated a contaminant from water according to an assumed bioconcentration factor. Equations for deriving ambient contaminant concentrations for the protection of human health are given by Nowell and Resek (1994).

For carcinogens, the human-health criteria are derived from a two-part evaluation in which the element is assigned a weight-of-evidence classification and a slope factor. The weight-ofevidence classification is the likelihood that an element is a human carcinogen. Arsenic, which is measured in filtered-water samples, has a "Group A" weight-of-evidence classification-a human carcinogen (U.S. Environmental Protection Agency, 1989). The slope factor is generally a plausible upper-bound estimate (95-percent confidence limit) of a human developing cancer as a result of a lifetime ( 70 years) of exposure to a particular level of a potential carcinogen. Slope factors are derived from mathematical models that are used on available data sets. These models extrapolate from carcinogenic responses observed at high doses in experimental animals to responses expected in humans from lower exposure levels in the environment. If the extrapolation model selected is EPA's linearized-multistage model (as in the case of arsenic), then the resultant slope factor is known as $\mathrm{q}_{1}$ * (U.S. Environmental Protection Agency, 1989). For example, the slope factor or $\mathrm{q}_{1} *$ for arsenic is a 1.75 risk per milligram contaminant per kilogram body weight per day (U.S. Environmental Protection Agency, 1995).

The derivation of human-health criteria for ambient stream water is contingent on several additional assumptions, which include:

Risk Level $(\mathrm{RL})=$ A unitless assigned level of maximum-acceptable individual-lifetime risk.

Screening values for human health are based on a RL of $10^{-5}$ - a level of risk not to exceed one excess case of cancer per 100,000 individuals exposed over a 70year lifetime (U.S. Environmental Protection Agency, 1993a).

Consumption Rate $(\mathrm{CR})=$ Mean daily consumption rate, in kilograms per day $(\mathrm{kg} / \mathrm{d})$, of the species of interest by the general population or subpopulation of concern averaged over a 70-year lifetime. Screening values for human health are derived using a CR of $0.0065 \mathrm{~kg} / \mathrm{d}$ - an estimate of the average fish and shellfish consumption by the general United States population (U.S. Environmental Protection Agency, 1993a). The value is equivalent to approximately one 6-ounce fillet of 
fish per month. In addition, screening concentrations that include a measure of chemical uptake from the consumption of water use a CR of 2 $\mathrm{L}$ of water per day (L/d) - an estimate of the average water consumption by the general United States population.

Body Weight $(\mathrm{BW})=$ Mean body weight, in $\mathrm{kg}$, of a standard adult within the general population or subpopulation of concern. Screening values for human health are derived using a BW of $70 \mathrm{~kg}$ (about 154 pounds), the average weight of the general United States population.

Biological Concentration Factor $(\mathrm{BCF})=$ The ratio of the contaminant concentration in an aquatic organism, in milligrams per kilogram, to the contaminant concentration in the surrounding water, in $\mathrm{mg} / \mathrm{L}$, reported in units of liters per $\mathrm{kg}(\mathrm{L} / \mathrm{kg})$. A weighted-average $\mathrm{BCF}$, adjusted to the average percent lipids in fish and shellfish ( 3 percent), is used by EPA in deriving human-health guidelines (U.S. Environmental Protection Agency, 1995).

The screening value for arsenic is based on the inorganic form only (U.S. Environmental Protection Agency, 1992b). The arsenic determination in this study, however, is based on both the organic and inorganic forms of arsenic. As a conservative assumption for screening, arsenic is assumed to reside in ambient waters in the pentavalent and (or) trivalent forms - the former being most likely in surface water (Eisler, 1988, p. 8). Methylated forms of arsenic also reside in surface water; their exact proportions, however, are not known (Hem, 1989, p. 144). Methylated forms are significantly less toxic than inorganic forms of arsenic (U.S. Environmental Protection Agency, 1992b; U.S. Environmental Protection Agency, 1993b, p. III-56).

For noncarcinogens, the screening values are based on a Reference Dose (RfD), rather than an $\mathrm{RL}$, which represents a daily exposure (with uncertainty spanning perhaps an order of magnitude or more) to the human population (including sensitive subpopulations) that is probably without appreciable risk of causing deleterious effects during a 70-year lifetime (U.S. Environmental Protection Agency, 1993a). Additionally, screening values for human health, which are derived from EPA ambient water-quality criteria for human health, are determined using the assumptions for BW, CR, and BCF listed above (U.S. Environmental
Protection Agency, 1995). For the purpose of calculating screening values for mercury (a noncarcinogen), the EPA recommends that the RfD for methylmercury be lowered from $3.0 \times 10^{-4}$ $\mathrm{mg} / \mathrm{kg} / \mathrm{d}$ to $6.0 \times 10^{-5} \mathrm{mg} / \mathrm{kg} / \mathrm{d}$ (U.S. Environmental Protection Agency, 1993a). The lowering of the RfD is based on evidence that the fetus, and possibly the pregnant woman, is at increased risk of adverse neurological effects from exposure to methylmercury.

Under the usual conditions of temperature and pressure, mercury in surface water exists in inorganic forms that include the liquid $\left(\mathrm{Hg}^{\circ}\right)$ and the ionic $\left(\mathrm{Hg}_{2}{ }^{+}\right.$and $\left.\mathrm{Hg}^{2+}\right)$ states. In addition, inorganic forms in sediment and water can be methylated to highly soluble and toxic methylmercury (Moore, 1991). The analytical technique used in this study for measuring mercury in ambient stream water is defined as a total- (inorganic plus organic) mercury analysis. For screening purposes, total-mercury concentrations are compared to the screening values for human health. Using total-mercury concentrations for comparison to screening values is conservative, because 100 percent of the mercury that accumulates in fish tissue (based on a BCF of $5,500 \mathrm{~L} / \mathrm{kg}$ ) is assumed to be in the toxic methylmercury form. It is this methylated form of mercury that is highly toxic to humans (U.S. Environmental Protection Agency, 1993a).

\section{Drinking-Water Quality}

Element concentrations determined from filtered-water samples were screened by making comparisons with EPA drinking-water regulations (U.S. Environmental Protection Agency, 1994b) and EPA advisories for human health (U.S. Environmental Protection Agency, 1995). The water samples from the lower Columbia River Basin that are compared to drinking-water guidelines represent untreated water (ambient stream water rather than finished or treated water available for distribution to community water supplies). The City of Longview diverts its water supply directly upstream from the Cowlitz River sampling location, and the City of Kalama diverts just downstream from the sampling location on the Kalama River. Although nearly all sites sampled in this study were not sources for domestic-water supplies, water-quality exceedances are important because the Washington sites are all in stream segments classified as class A waters. It is 
important to note, however, that "although a surface water in Washington State may be designated as a potential domestic-water source" in Chapter 173201 in the Washington State Administrative Code (1992), "approval for such use must first be obtained from the Washington State Department of Health following an evaluation of the water quality" (Harriet Ammann, Denise Laflamme, and Glen Patrick, Washington State Department of Health, written commun., 1993). Thus, the presence in filtered stream-water samples of elements in concentrations that exceed screening values (drinking-water regulations) does not indicate that human health is directly at risk.

\section{Regulations}

The types of primary and secondary drinkingwater regulations set forth by the EPA include Maximum Contaminant Levels (MCLs) and Maximum Contaminant Level Goals (MCLGs) (U.S. Environmental Protection Agency, 1991). The MCLs represent achievable levels of drinking-water quality that take into consideration health effects, treatment feasibility, and aesthetic considerations. The MCLGs are nonenforceable health goals that are not expected to cause any adverse human-health effects over a lifetime of exposure and include a margin of safety.

\section{Health Advisories}

Concentrations of constituents in filtered-water samples are screened for human-health effects by making comparisons to human-health advisories for drinking water (U.S. Environmental Protection Agency, 1994b). Unlike the ambient water-quality criteria, human-health advisories for drinking water are based only on the consumption of domestic water. In this study, however, ambient stream water is used to screen for health effects. Additionally, the aforementioned assumptions for BW $(70 \mathrm{~kg}), \mathrm{CR}(2$ $\mathrm{L} / \mathrm{d}$ of water), and $\mathrm{RL}\left(10^{-5}\right)$ are applicable to screening values for human-health advisories. For the carcinogen arsenic, the human-health advisory is a risk specific dose (RSD) associated with a specified RL and is calculated from the $\mathrm{q}_{1}$ * for arsenic (Nowell and Resek, 1994). For the noncarcinogen mercury, the human-health advisory is a lifetime-health advisory which is equal to 20 percent of the drinking-water equivalent level (DWEL). The DWEL is the highest lifetime- exposure level in drinking water, assuming 100 percent exposure from that medium, at which adverse noncarcinogenic health effects would not be expected to occur (Nowell and Resek, 1994).

\section{ANALYSIS OF AVAILABLE SURFACE-WATER-QUALITY DATA}

This section of the report is organized into topical water-quality sections, which include current (1994) and historical analyses (1939-93) of water temperature, dissolved oxygen and $\mathrm{pH}$, total dissolved gas, suspended sediment, nutrients, major ions and related measures, trace elements, organic compounds, fecal-indicator bacteria, and radionuclides. Exceedances of water-quality guidelines by samples collected in the current (1994) study are discussed within the topical water-quality sections that follow. Specific information pertaining to the number of exceedances, sites with exceedances, and criteria and guidelines used to derive screening values are in tables 47,48 , and 49 (at back of report).

\section{Water Temperature}

The principal factors controlling riverine-water temperatures are energy-transfer processes. These processes include radiation inputs (air temperature, which varies with elevation and latitude), convection/advection (vertical and horizontal mixing, which varies with stream velocity, depth, and roughness of the stream channel), evaporation, and inflow of water of different temperature. Riverine-water temperature is important in a biological sense, because increased water temperatures are known to increase biological activity, which in turn increases the metabolic rate of cold-blooded aquatic organisms (MacDonald and others, 1991). High water temperature also can affect the survival of salmonid eggs and juvenile salmonids. The lethal-temperature limit for eggs of sockeye salmon is $13.5^{\circ} \mathrm{C}$ (MacDonald and others, 1991, p. 74). Spawning coho and steelhead may be intolerant of temperatures exceeding $10^{\circ} \mathrm{C}$.

Interspecies competition (for example warm-water versus cold-water fishes) is dependent upon water temperature (U.S. Environmental Protection Agency, 1986a). Unsuitable water temperatures can lead to 
disease outbreaks in migrating and spawning salmonids (Bjornn and Reiser, 1991).

The distribution of daily mean water temperatures was determined from continuous temperature recording stations at 14 sites in the lower Columbia River Basin. Periods of record at the various sites ranged from as few as 2 years (1968-69 WY) for the Columbia River at Prescott to as many as 17 years (1975-92 WY) for the Columbia River at Warrendale (table 13). The most recent continuous temperature measurements were made at the Columbia River at Beaver Army Terminal.

The distribution of daily mean water temperatures was generally uniform among sites in the lower Columbia River (fig. 15). These findings coincide with results from an earlier study by Moore (1968), who profiled water temperatures of the Columbia River from RM 928 to 53.5. Moore's temperature profiles show that the overall temperature gradient from the Canadian border to the mouth of the Columbia River was upward (July 1966 through September 1967), with increases ranging from 1 to $5^{\circ} \mathrm{C}$ per month from July through August. However, the principal temperature increases occurred well upstream of the lower Columbia River in an area between Coulee Dam (RM 596.6) and McNary Dam (RM 292). On the basis of monthly mean water temperatures for the period 1938-65, which includes effects of Brownlee Reservoir on the Snake River and stepped-up operations at Hanford (near RM 375), temperatures in the Columbia River at Bonneville Dam exceeding $20^{\circ} \mathrm{C}$ were measured as early as 1938 . Additionally, the mean monthly water temperature for August $\left(21.1^{\circ} \mathrm{C}\right)$ for the $1938-65$ period also exceeded $20^{\circ} \mathrm{C}$ at Bonneville Dam.

Streamflow in the Willamette River did not significantly affect water temperature in the

Table 13. Water-quality sites that have continuous record of stream temperature, lower Columbia River Basin, Oregon and Washington, 1968-94 [Computer retrieval of chemical data by either the U.S. Geological Survey's (USGS) National Water Information System (NWIS) or U.S. Environmental Protection Agency's STOrage and RETrieval system (STORET) can be made using the USGS site number]

\begin{tabular}{rlc}
\hline $\begin{array}{c}\text { USGS site } \\
\text { number }\end{array}$ & \multicolumn{1}{c}{ Site name } & Period of record \\
\hline 14128910 & Columbia River at Warrendale & $1975-92$ \\
14144700 & Columbia River at Vancouver & $1968-70 ; 1973-79$ \\
14211720 & Willamette River at Portland & $1976-81$ \\
14211805 & Willamette River above St. Johns Bridge & $1972-75$ \\
14222880 & Columbia River at Columbia City & 1971 \\
14222890 & Columbia River near Columbia City & $1969-72$ \\
14222910 & Columbia River at Kalama & $1969-79$ \\
14223780 & Columbia River at Prescott & $1968-69$ \\
14245295 & Columbia River at Rainier & $1972-79$ \\
14245300 & Columbia River at Longview & $1968-72$ \\
14246900 & Columbia River at Beaver Army Terminal & $1968-70 ; 1994-$ present \\
14247295 & Columbia River at Wauna & $1972-76$ \\
14247400 & Columbia River at Bradwood & $1977-81$ \\
14248600 & Columbia River at Altoona & $1972-79$ \\
\hline
\end{tabular}




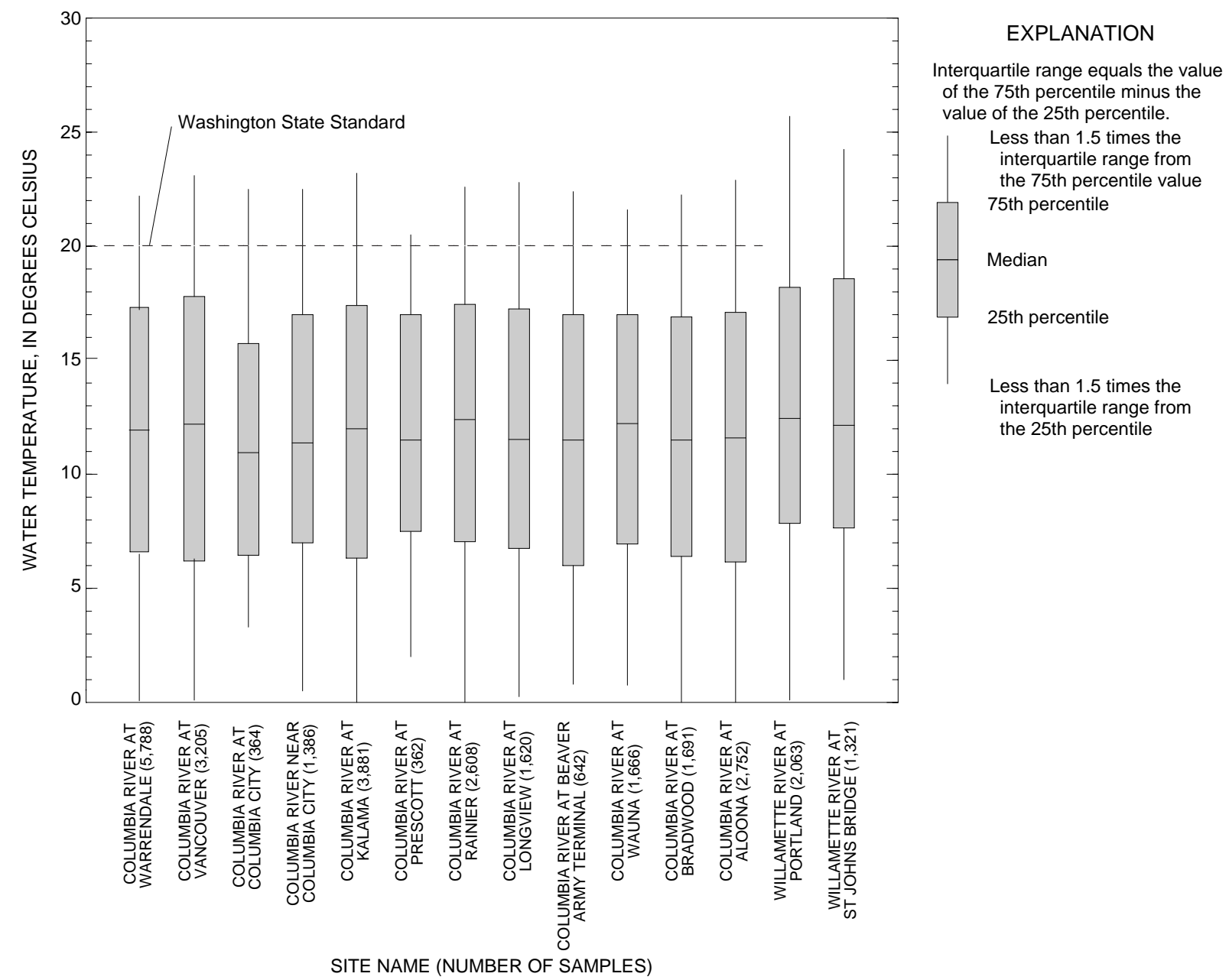

Figure 15. Distribution of daily mean water temperatures in the lower Columbia River Basin, Oregon and Washington, 1968-94 water years.

Columbia River during the period July 1966 to September 1967. On the basis of median (50thpercentile) daily mean water temperatures from historical data analyzed in this study, the Willamette River differed only slightly from the Columbia River. Specifically, the 75th-percentile values at the two Willamette River sites were slightly higher (by 0.4 to $0.8^{\circ} \mathrm{C}$ ) than the 75 th-percentile value $\left(17.8^{\circ} \mathrm{C}\right.$ ) in the Columbia River at Vancouver (fig. 15). A temperature gradient between the Willamette River and the Columbia River during the summer months may be expected; however, a gradient is not noticeable due to the large difference in streamflow in the two river systems. During a median streamflow year (1967), the mean monthly streamflow in the Willamette River at Portland for the summer months $\left(7,500 \mathrm{ft}^{3} / \mathrm{s}\right)$ was about 4 percent of the mean monthly streamflow in the Columbia River at Vancouver for the same time period. The absence of a temperature gradient may also result from tidal flow reversals and the associated mixing at the confluence of the two rivers.

The median daily mean water temperatures in the lower Columbia River (1968-92 WY) and in the Willamette River at Portland (1976-81 WY) were highest during August (fig. 16). In the Columbia River at Bradwood (RM 38.9), for example, 75 percent of the daily mean water temperatures (1977$81 \mathrm{WY}$ ) measured during August exceeded $20^{\circ} \mathrm{C}-$ only about 10 percent of the temperatures exceeded $20^{\circ} \mathrm{C}$ during the months of July and September (table 14).

Results of the seasonal Kendall trend test for water temperature indicate that significant $(\rho<0.05)$ upward trends exist in the Columbia River at Warrendale and Willamette River at Portland (table 50 , at back of report). At Warrendale, the median water temperature was $11.9^{\circ} \mathrm{C}$, and the seasonal 


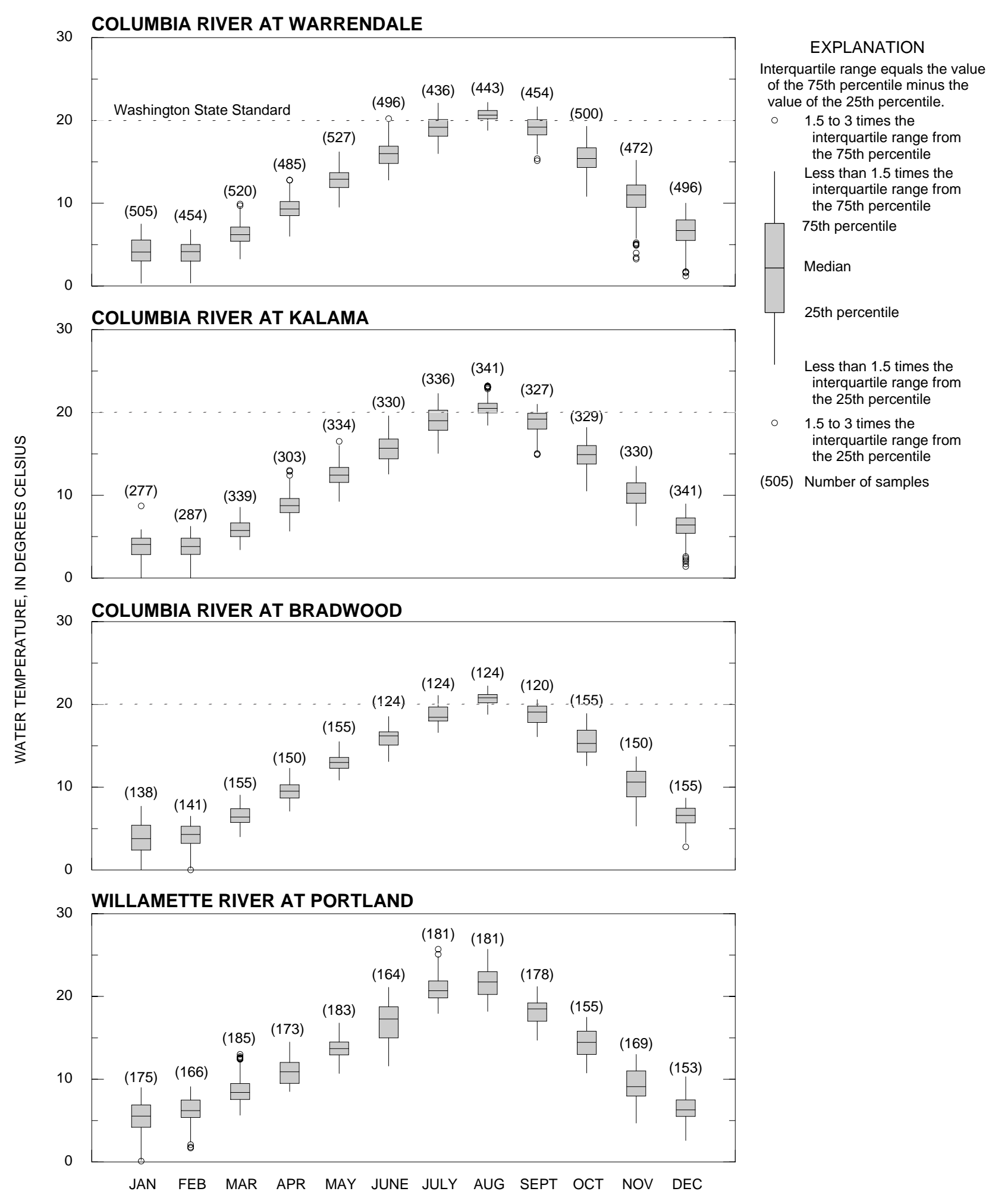

Figure 16. Distribution of daily mean water temperatures in the Columbia River at Warrendale, Kalama, and Bradwood and inthe Willamette River at Portland, lower Columbia River Basin, Oregon and Washington, 1975-92. 
Table 14. Monthly distributions of daily mean water temperatures at selected sites, lower Columbia River Basin, Oregon and Washington, 1969-92

[Values are reported in degrees Celsius; shaded numbers represent water temperatures that exceed the Washington State standard of 20 degrees Celsius (Washington State Administrative Code, 1992)]

\begin{tabular}{|c|c|c|c|c|c|c|c|c|}
\hline \multirow{2}{*}{ Month } & \multirow{2}{*}{$\begin{array}{c}\text { Number of } \\
\text { measurements }\end{array}$} & \multirow{2}{*}{$\begin{array}{l}\text { Minimum } \\
\text { value }\end{array}$} & \multicolumn{5}{|c|}{ Value at indicated percentile } & \multirow{2}{*}{$\begin{array}{l}\text { Maximum } \\
\text { value }\end{array}$} \\
\hline & & & 10 & 25 & 50 & 75 & 90 & \\
\hline \multicolumn{9}{|c|}{ Columbia River at Warrendale, Oregon, 1976-92 } \\
\hline January & 505 & 0.0 & 2.2 & 3.0 & 4.1 & 5.6 & 6.3 & 7.5 \\
\hline February & 454 & .3 & 2.0 & 3.0 & 4.2 & 5.0 & 5.6 & 6.8 \\
\hline March & 520 & 3.3 & 4.7 & 5.4 & 6.2 & 7.1 & 7.7 & 9.9 \\
\hline April & 485 & 6.0 & 7.7 & 8.5 & 9.3 & 10.2 & 11.1 & 12.8 \\
\hline May & 527 & 9.5 & 10.9 & 11.9 & 12.9 & 13.7 & 14.4 & 16.2 \\
\hline June & 496 & 12.8 & 13.9 & 14.8 & 16.0 & 16.9 & 17.7 & 20.2 \\
\hline July & 436 & 16.0 & 17.3 & 18.1 & 19.2 & 20.1 & 20.5 & 22.1 \\
\hline August & 443 & 18.8 & 19.5 & 20.2 & 20.6 & 21.2 & 21.6 & 22.2 \\
\hline September & 454 & 15.2 & 17.3 & 18.3 & 19.2 & 20.1 & 20.8 & 21.7 \\
\hline October & 500 & 10.8 & 13.2 & 14.3 & 15.4 & 16.7 & 17.7 & 19.3 \\
\hline November & 472 & 3.3 & 8.1 & 9.5 & 11.0 & 12.2 & 13.0 & 15.2 \\
\hline December & 496 & 1.2 & 3.2 & 5.5 & 6.7 & 8.0 & 8.9 & 10.0 \\
\hline \multicolumn{9}{|c|}{ Columbia River at Kalama, Washington, 1969-79 } \\
\hline January & 277 & .0 & 1.9 & 2.8 & 4.0 & 4.8 & 5.2 & 8.7 \\
\hline February & 287 & .0 & 2.0 & 2.9 & 3.8 & 4.8 & 5.5 & 6.2 \\
\hline March & 339 & 3.4 & 4.0 & 5.0 & 5.7 & 6.7 & 7.2 & 8.6 \\
\hline April & 303 & 5.7 & 7.0 & 7.9 & 8.8 & 9.6 & 10.3 & 13.0 \\
\hline May & 334 & 9.3 & 10.8 & 11.6 & 12.4 & 13.4 & 14.3 & 16.5 \\
\hline June & 330 & 12.6 & 13.7 & 14.4 & 15.7 & 16.8 & 18.0 & 19.6 \\
\hline July & 336 & 15.1 & 16.6 & 17.9 & 19.0 & 20.3 & 20.9 & 22.3 \\
\hline August & 341 & 18.5 & 19.5 & 20.0 & 20.5 & 21.1 & 21.8 & 23.2 \\
\hline September & 327 & 14.9 & 17.0 & 18.0 & 19.2 & 19.9 & 20.3 & 21.0 \\
\hline October & 329 & 10.5 & 13.0 & 13.8 & 14.9 & 16.0 & 17.0 & 18.2 \\
\hline November & 330 & 6.3 & 8.1 & 9.0 & 10.2 & 11.5 & 12.4 & 13.5 \\
\hline December & 341 & 1.4 & 4.7 & 5.4 & 6.4 & 7.2 & 8.0 & 9.0 \\
\hline \multicolumn{9}{|c|}{ Columbia River at Bradwood, Washington, 1977-81 } \\
\hline January & 138 & .0 & 0.7 & 2.4 & 3.8 & 5.4 & 6.0 & 7.7 \\
\hline February & 141 & .0 & 2.0 & 3.2 & 4.3 & 5.3 & 6.1 & 6.5 \\
\hline March & 155 & 4.0 & 5.5 & 5.7 & 6.4 & 7.4 & 7.9 & 9.1 \\
\hline April & 150 & 7.1 & 7.9 & 8.7 & 9.5 & 10.3 & 10.9 & 12.3 \\
\hline May & 155 & 10.9 & 11.9 & 12.3 & 13.0 & 13.6 & 14.5 & 15.5 \\
\hline June & 124 & 13.1 & 14.3 & 15.1 & 16.2 & 16.7 & 17.6 & 18.5 \\
\hline July & 124 & 16.6 & 17.4 & 18.0 & 18.5 & 19.7 & 20.6 & 21.1 \\
\hline August & 124 & 18.8 & 19.6 & 20.2 & 20.8 & 21.2 & 21.6 & 22.3 \\
\hline September & 120 & 16.1 & 16.9 & 17.8 & 19.1 & 19.8 & 20.2 & 20.6 \\
\hline October & 155 & 12.6 & 13.6 & 14.3 & 15.3 & 16.9 & 17.6 & 18.9 \\
\hline November & 150 & 5.3 & 7.1 & 8.8 & 10.6 & 11.9 & 12.7 & 13.7 \\
\hline December & 155 & 2.8 & 4.8 & 5.7 & 6.6 & 7.5 & 7.9 & 8.7 \\
\hline \multicolumn{9}{|c|}{ Willamette River at Portland, Oregon, 1976-81 } \\
\hline January & 175 & 0.1 & 2.5 & 4.2 & 5.6 & 6.9 & 7.6 & 9.0 \\
\hline February & 166 & 1.7 & 4.4 & 5.4 & 6.2 & 7.5 & 8.6 & 9.1 \\
\hline March & 185 & 5.7 & 6.8 & 7.5 & 8.4 & 9.5 & 10.2 & 13.0 \\
\hline April & 173 & 8.5 & 9.0 & 9.5 & 10.9 & 12.0 & 12.8 & 14.5 \\
\hline May & 183 & 10.7 & 12.2 & 13.0 & 13.7 & 14.5 & 15.5 & 16.8 \\
\hline June & 164 & 11.6 & 13.6 & 15.0 & 17.3 & 18.8 & 19.7 & 21.1 \\
\hline July & 181 & 18.0 & 18.9 & 19.8 & 20.7 & 21.9 & 23.2 & 25.7 \\
\hline August & 181 & 18.2 & 18.9 & 20.3 & 21.8 & 23.0 & 24.9 & 25.7 \\
\hline September & 178 & 14.7 & 15.9 & 17.0 & 18.5 & 19.2 & 19.8 & 21.2 \\
\hline October & 155 & 10.8 & 12.2 & 13.0 & 14.5 & 15.8 & 16.9 & 17.5 \\
\hline November & 169 & 4.7 & 6.3 & 8.0 & 9.1 & 11.0 & 11.7 & 13.0 \\
\hline December & 153 & 2.6 & 5.1 & 5.5 & 6.3 & 7.5 & 8.5 & 10.3 \\
\hline
\end{tabular}


Kendall slope estimator shows that water temperature has been increasing at a rate of $0.073^{\circ} \mathrm{C}$ per year, which represents a 0.6 -percent change in the median water temperature per year. Data were unavailable for calculating a flow-adjusted trend at Warrendale. Both nonflow-adjusted and flowadjusted trends, however, were found in the Willamette River. The median water temperature in the Willamette River was $12.5^{\circ} \mathrm{C}$, and the seasonal Kendall slope estimator (nonflow-adjusted) shows that water temperature has been increasing by $0.14^{\circ} \mathrm{C}$ per year which represents a 1.1 -percent change in the median water temperature per year. The flow-adjusted trend is smaller, however, representing only 0.9 percent of the median temperature per year.

The instantaneous water temperatures measured during July, August, and September, 1994, were generally similar at the main-stem sites (fig. 17). During July and August temperatures exceeded $20^{\circ} \mathrm{C}$, and during September they were nearly $20^{\circ} \mathrm{C}$. The Willamette River generally was the warmest tributary entering the main stem during the July to September period-instantaneous water temperatures were as high as $24.2^{\circ} \mathrm{C}$. Conversely, the Lewis River and the Kalama River were the coldest tributaries entering the main stem during the July to September period-instantaneous water temperatures were as low as $14.3^{\circ} \mathrm{C}$ in the Lewis River and $15.8^{\circ} \mathrm{C}$ in the Kalama River.

In this study, instantaneous water temperature (for sites sampled in the lower Columbia River and Washington tributaries) were evaluated against water-quality standards for class A waters according to the Washington State Administrative Code (1992). The Code, which has special conditions for the lower Columbia River (main stem), states that freshwater-stream temperatures in the lower Columbia River " **** shall not exceed $20.0^{\circ} \mathrm{C}$ due to human activities ***"; all other freshwater-stream temperatures from Washington waters designated as class A (the Lewis, Kalama, and Cowlitz Rivers for this study) “*** shall not exceed $18.0^{\circ} \mathrm{C}$ due to human activity***."

Temperature standards used by the State of Oregon are not directly applicable to instantaneous temperature measurements in ambient streamwater. Rather, they were designed to regulate temperature effects to rivers and streams from individual point sources. For example, for the lower Willamette
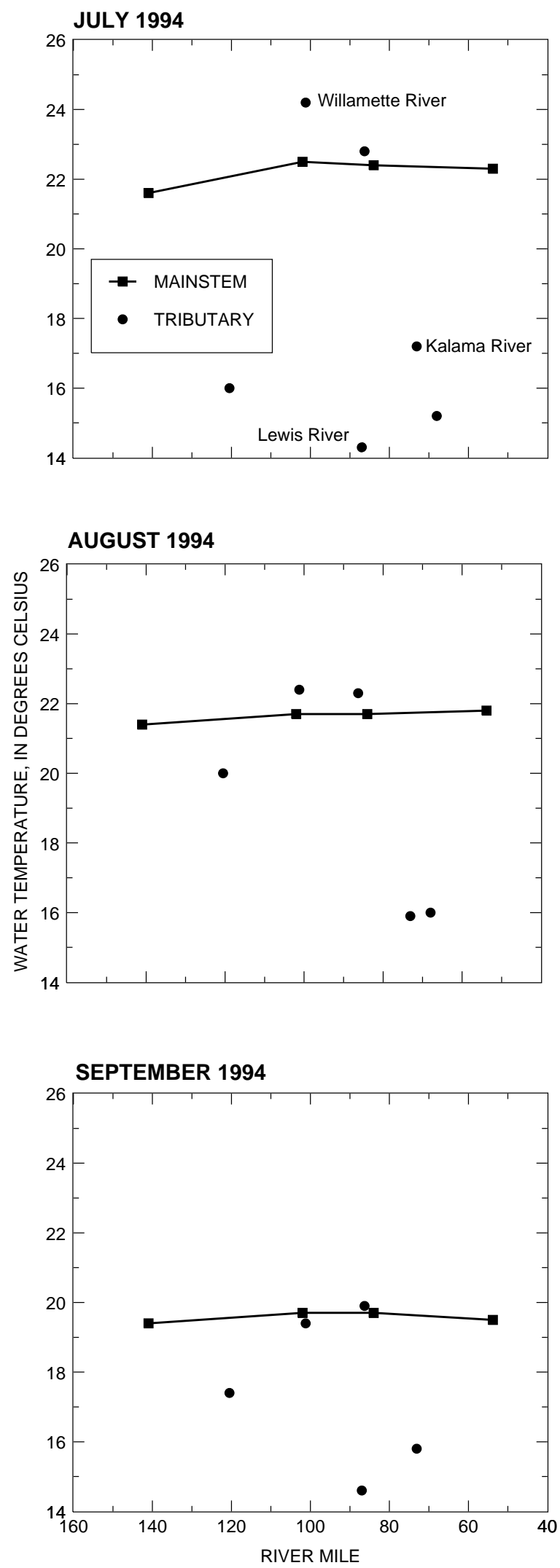

Figure 17. Instantaneous water temperatures in the main stem and tributaries of the lower Columbia River Basin, Oregon and Washington, July to September 1994. (See table 7 for full site names.) 
River Basin (including Multnomah Channel), the State of Oregon (1994) states that "No measurable increases [in water temperature] shall be allowed outside of the assigned mixing zone, as measured relative to a control point immediately upstream from a discharge, when stream temperatures are $70^{\circ} \mathrm{F}\left[21^{\circ} \mathrm{C}\right]$ or greater $* * * . "$ Because individual measurements of point-source water temperatures were beyond the scope of this study, instantaneous water temperatures in Oregon tributaries were not evaluated relative to temperature standards.

The water temperatures in the main stem of the lower Columbia River exceeded the Washington water-quality standard $\left(20^{\circ} \mathrm{C}\right)$ in 15 percent of the samples (table 47, at back of report), including consistent exceedances during July and August, 1994. This period coincides with seasonal high air temperatures and low streamflows, is consistent with historical water-temperature exceedances (table 14), and reflects water temperature concerns in the main stem of the lower Columbia River.

\section{Dissolved Oxygen and $\mathrm{pH}$}

Most aquatic organisms require adequate dissolved-oxygen concentrations and a suitable $\mathrm{pH}$ range at all times. Anadromous cold-water fish are particularly sensitive to the dissolved-oxygen concentration and $\mathrm{pH}$ of fresh and marine waters. The Oregon freshwater regulatory standard states that dissolved oxygen should not be less than 90percent saturation in the Columbia River and not less than $5 \mathrm{mg} / \mathrm{L}$ in the Willamette Harbor and Multnomah Channel (State of Oregon, 1994). The Washington standard states that dissolved-oxygen concentrations should not be less than 90-percent saturation in the Columbia River and should exceed $8 \mathrm{mg} / \mathrm{L}$ in Washington tributaries in the lower Columbia River drainage (Washington Administrative Code, 1992). Both agencies have standards requiring that $\mathrm{pH}$ not be less than 6.5 or greater than 8.5 for the lower Columbia River.

The solubility of oxygen in water is directly proportional to the partial pressure of oxygen above the water. The concentration of dissolved oxygen in water at saturation decreases as barometric pressure decreases (altitude increases) and (or) as water temperature increases. In addition, oxygen solubility decreases as the dissolved-solids content increases. The concentration of oxygen can also be changed by (1) aquatic plants producing oxygen as a product of photosynthesis, (2) aquatic organisms consuming oxygen as they respire, and (3) the physical process of spilling water at dams, which causes air bubbles to be entrained in the flow (Wilhelms and Gulliver, 1994). Aquatic plants will cause dissolved-oxygen concentrations to show diel (over the 24 hours in a day) variability, with maximum concentrations in the afternoon and minimum concentrations in the early morning.

Dissolved-oxygen concentrations in the lower Columbia River Basin during 1994 are summarized in figure 18. Concentrations at all Columbia River main-stem sites met the Oregon and Washington dissolved-oxygen standards. The Washington tributary sites had no dissolved-oxygen measurements that were below the Washington State standard. The Oregon tributary, Sandy River near Troutdale, had one dissolved-oxygen measurement below the Oregon State standard (table 47, at back of report). The Sandy River sample was measured during August when water temperatures were high and biological respiration was at a maximum.

Examples of seasonal variability of dissolved oxygen are shown in figures 19,20 , and 21 . The box plots of data for the Columbia River at Warrendale in figure 19 indicate that there was minimal seasonal variability of dissolved oxygen (in percent saturation) for the 1974 to 1994 period. The 1994 data were typical of concentrations measured earlier. While there have been measurements of dissolvedoxygen concentrations that were below State standards, they generally were infrequent, occurring less than 25 percent of the time. During March through June and much of July, dissolved oxygen at Warrendale was usually supersaturated (above 100 percent of saturation). This pattern is the result of spilling water at the Bonneville Dam and other dams upstream on the Columbia River (U.S. Army Corps of Engineers, 1993).

Figure 20 shows dissolved-oxygen concentrations in the Willamette River at Portland. Figure 20a shows dissolved-oxygen concentrations measured from 1949 through 1958, when median concentrations during July, August, and September did not meet the State standard of $5 \mathrm{mg} / \mathrm{L}$. Comparison of figures 20a and 20b (1972-94) indicates a significant increase in dissolved-oxygen concentrations, which is likely the result of U.S. Army Corps of Engineers dams releasing water 


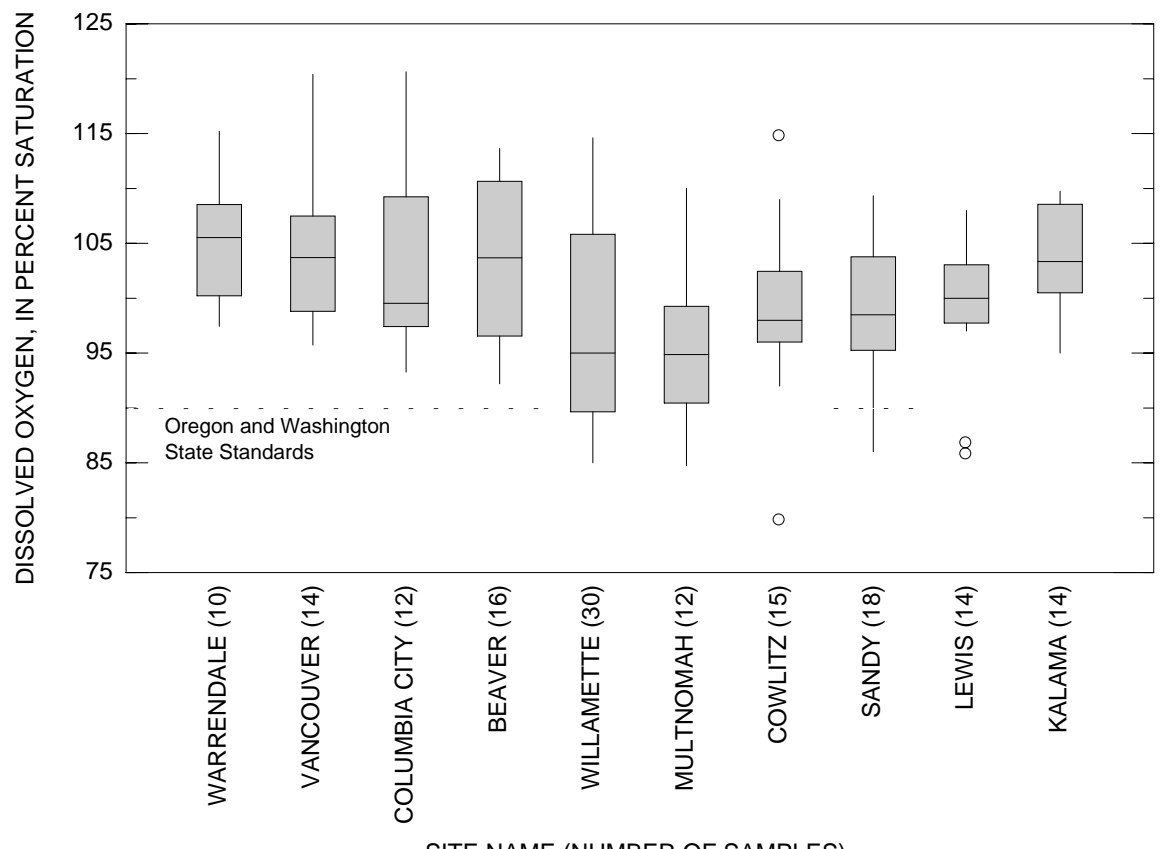

EXPLANATION

Interquartile range equals the value

of the 75th percentile minus the

value of the 25th percentile.

- 1.5 to 3 times the

interquartile range from

the 75th percentile

Less than 1.5 times the interquartile range from the 75 th percentile

75th percentile

Median

25th percentile

Less than 1.5 times the interquartile range from the 25th percentile

- 1.5 to 3 times the interquartile range from the 25th percentile

SITE NAME (NUMBER OF SAMPLES)

Figure 18. Distribution of dissolved-oxygen concentrations, lower Columbia River Basin, Oregon and Washington, 1994. (See table 7 for full site names; see State of Oregon [1994] and Washington State Administrative Code [1992] for standards.)

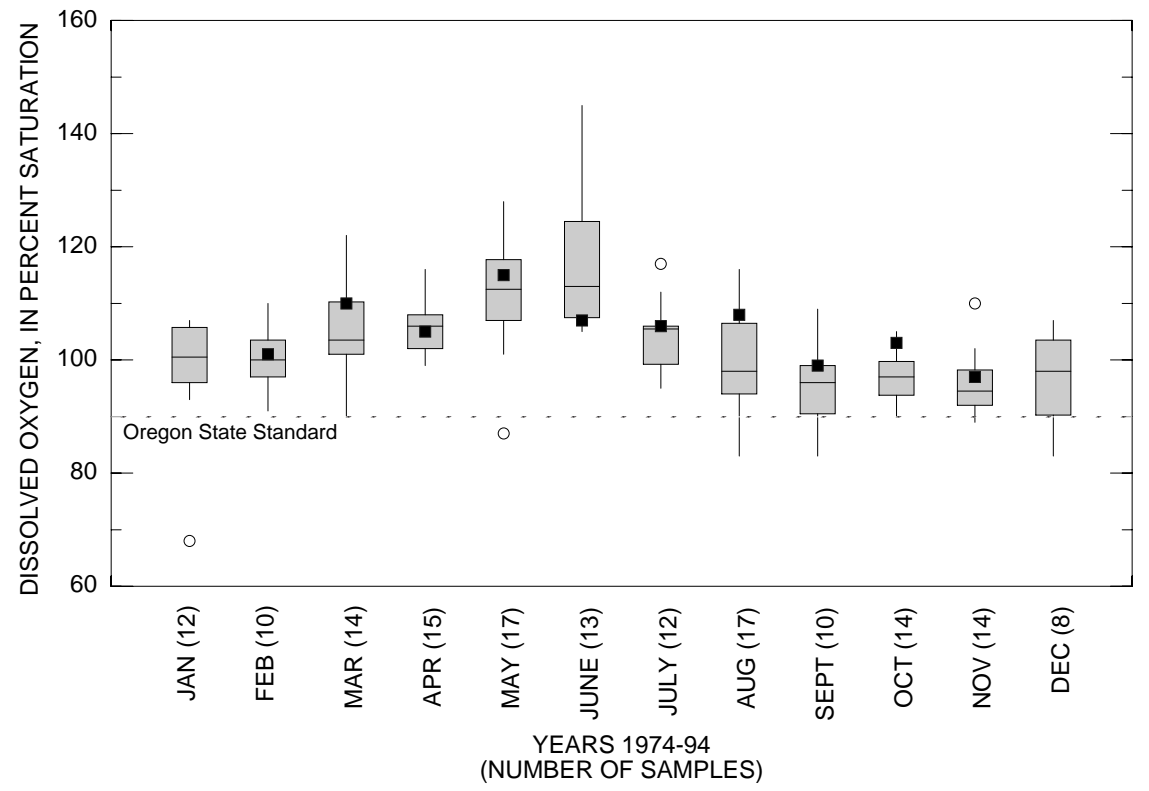

EXPLANATION

Interquartile range equals the value of the 75th percentile minus the value of the 25 th percentile.

- 1.5 to 3 times the interquartile range from the 75-percentile value Less than 1.5 times the interquartile range from the 75 th percentile 75th percentile

Median

25th percentile

Less than 1.5 times the interquartile range from the 25th percentile

1.5 to 3 times the interquartile range from the 25 th percentile

- 1994 concentrations

Figure 19. Distribution of 1974-94 and 1994 dissolved-oxygen concentrations measured in the Columbia River at Warrendale, lower Columbia River Basin, Oregon. (To avoid statistical bias that may be associated with constituents analyzed more than once at a site, only one concentration per day was statistically summarized; see State of Oregon [1994] for standards.) 

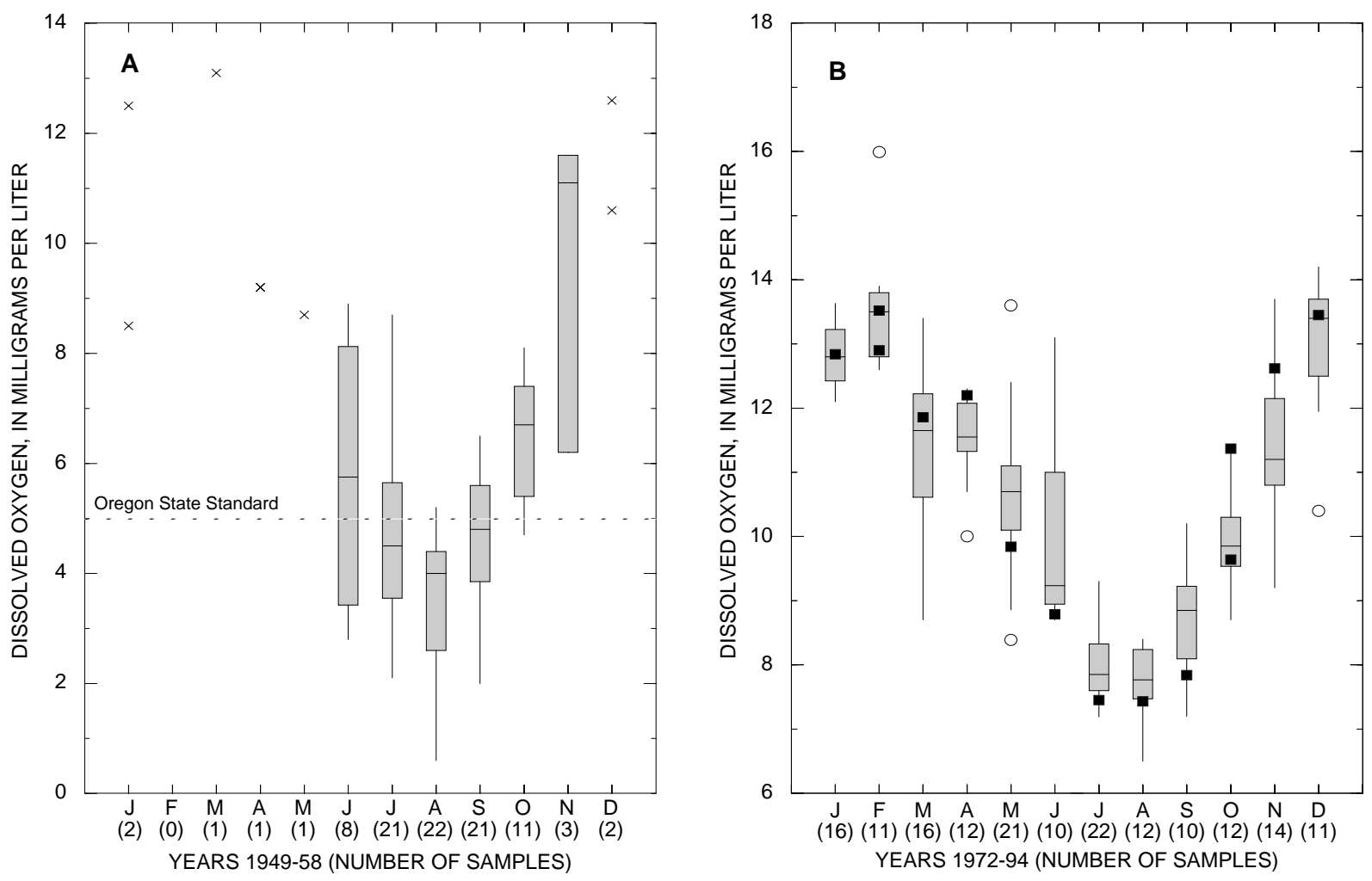

NS 1949-58 (NUMBER OF SAMPLES)

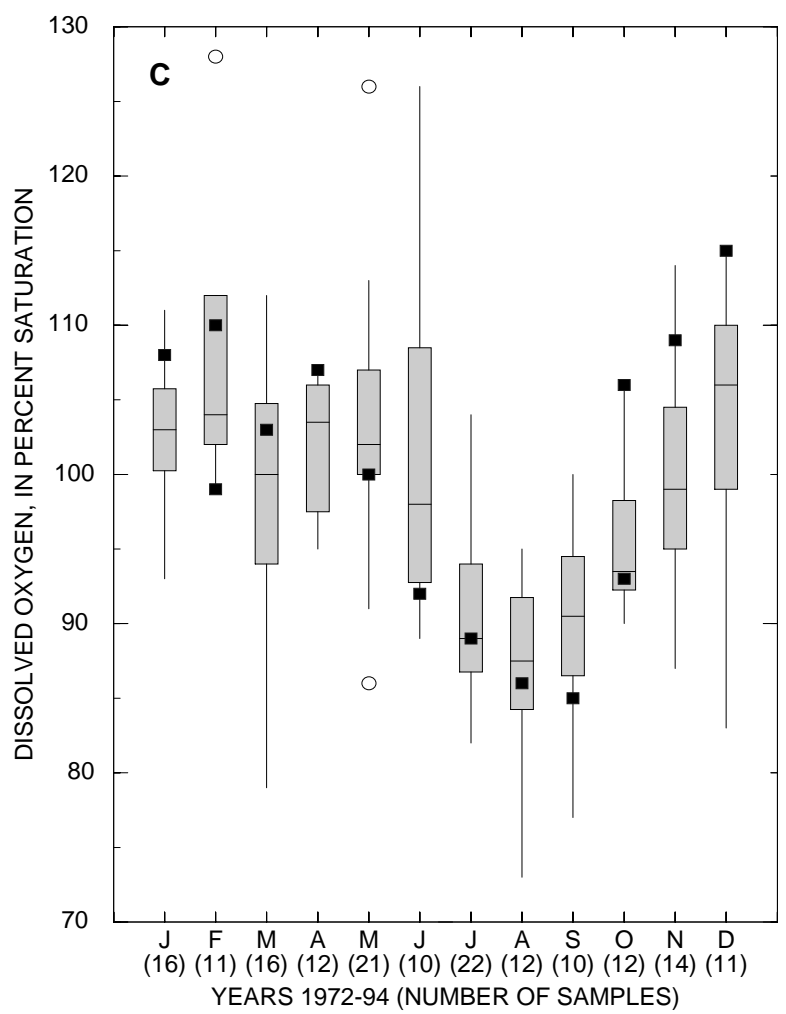

Figure 20. Distribution of (A) 1949-58, (B) 1972-94, and 1994 dissolved-oxygen concentrations measured in the Willamette River at Portland, lower Columbia River Basin, Oregon. (To avoid statistical bias that may be associated with constituents analyzed more than once at a site, only one concentration per day was statistically summarized; see State of Oregon [1994] for standards.) 

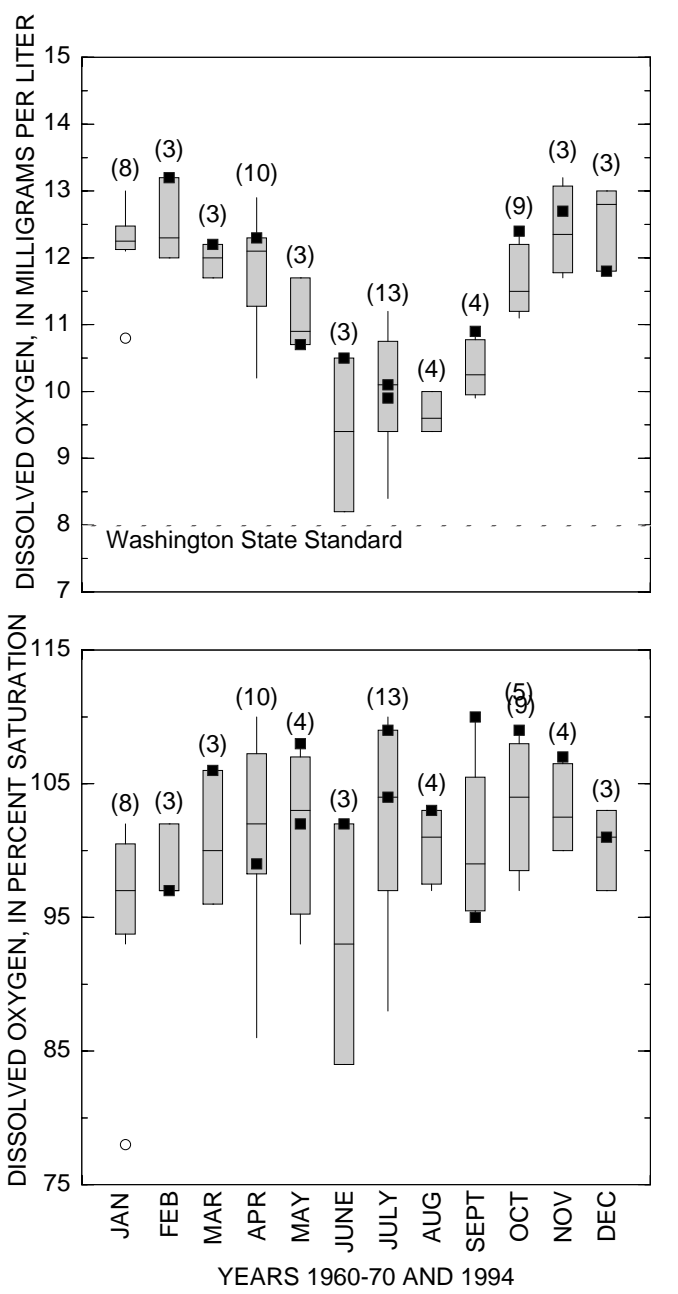

YEARS 1960-70 AND 1994

EXPLANATION

Interquartile range equals the value of the 75th percentile minus the value of the 25 th percentile.

Less than 1.5 times the

interquartile range from

the 75th percentile

75th percentile

Median

25th percentile

Less than 1.5 times the interquartile range from the 25th percentile

1.5 to 3 times the

interquartile range from

the 25 th percentile

- 1994 concentrations

(8) Number of samples

Figure 21. Distribution of 1960-74 and 1994 dissolvedoxygen concentrations measured in the Kalama River above Spencer Creek near Kalama, lower Columbia River Basin, Washington. (To avoid statistical bias that may be associated with constituents analyzed more than once at a site, only one concentration per day was statistically summarized; see State of Oregon [1994] for standards.) during the summer for navigation (Sherman, 1976) and the upgrading of wastewater discharges in the Willamette River Basin to secondary treatment levels by 1972 (Rickert and others, 1976). The major reason for the seasonal variability apparent in figures $20 \mathrm{~b}$ and $20 \mathrm{c}$ can be attributed to temperature effects. Figure $20 \mathrm{~b}$ can be viewed as an inverse of figure 16, which shows the monthly variability of temperature. Figure 20c shows that except for the months of July through September, the dissolvedoxygen concentrations were generally within 10 percent of saturation. During the low-flow summer period, the dissolved-oxygen concentrations were low probably because point and nonpoint sources were still placing a biochemical demand on the river and biological respiration is consuming oxygen at a maximum rate during this period of maximum temperatures. Most of the dissolved-oxygen concentrations during the months of December, January, February, April, and May were above 100-percent saturation, likely as a result of aeration caused by water spilling over Willamette Falls (RM 26.6).

Dissolved-oxygen concentrations in the Kalama River (fig. 21) are typical of a natural stream, with water temperature being the dominant factor on seasonal variability. As an example, very few of the percent-saturation data in figure 21 fall outside the range of plus or minus 10 percent of saturation. Comparison of 1994 data to historical data suggests that dissolved-oxygen concentrations in 1994 were similar to those measured in 1960-74.

The $\mathrm{pH}$ of a water sample is a measure of its hydrogen-ion activity. Water is neutral at a $\mathrm{pH}$ of 7 and the $\mathrm{pH}$ can range from a minimum of 0 (highly acidic) to a maximum of 14 (highly alkaline). The $\mathrm{pH}$ of a stream can change because of an influx of acidic or alkaline wastes or because of photosynthesis and respiration (due to the daily cycles of release and uptake of carbon dioxide by aquatic plants). The toxicity to aquatic organisms of several chemical constituents is affected by $\mathrm{pH}$, both directly and indirectly. Toxicity to freshwater aquatic life can occur when the $\mathrm{pH}$ falls outside the range of 6.5 to 8.5 . A pH range of 5 to 9 is necessary for water to be suitable for domesticwater supplies (U.S. Environmental Protection Agency, 1986a). The dissociation of weak acids and bases is influenced by $\mathrm{pH}$, which in turn, indirectly affects aquatic life. For example, as $\mathrm{pH}$ increases, 
the ammonium ion is dissociated to the toxic unionized ammonia form.

In 1994, three measurements in the lower Columbia River exceeded $\mathrm{pH}$ of 8.5 during April and May (fig. 22a, and table 48 at back of report). There were, however, no $\mathrm{pH}$ measurements near the lower limit of 6.5. The higher $\mathrm{pH}$ values were not associated with changes in alkalinity or specific conductance. The higher $\mathrm{pH}$ measurements in April and May in the Columbia River at RM 102 downstream from Hayden Island are associated with increased chlorophyll $a$ concentrations (an indirect measure of algal productivity) in the water column (fig. 22b). The associated seasonal increase of $\mathrm{pH}$ and chlorophyll $a$ suggests that phytoplankton may have been an important factor relative to $\mathrm{pH}$ levels in the lower Columbia River during April and May of 1994

\section{Total Dissolved Gas}

Water is spilled at Columbia River dams when flows exceed the dams' capacity to store water or generate hydropower and to aid downstream migration of anadromous juvenile fish. Because of the Columbia River depths and the configuration of the dams spilling water into the next downstream pool, the spills usually cause atmospheric gasses to go into solution, resulting in supersaturation of gases in the river. When aquatic organisms are exposed to these supersaturated concentrations, they can develop Gas-Bubble Trauma (National Marine Fisheries Service, 1994). Some of the associated difficulties for outmigrating juvenile salmonids are identified in table 15 .

Oregon and Washington both have State standards of 110 percent of saturation for total dissolved gas (TDG). TDG is equal to the sum of the partial pressures of nitrogen gas, oxygen gas, argon gas, and water vapor. State and Federal fishery agencies requested the States of Washington and Oregon to allow a variance to the TDG standard during the spring and summer of 1994 that would allow up to a 120 percent of saturation on a 24 -hour average. The request was made to permit the release of water over spillways, thereby allowing migrating salmon smolt to avoid hydropower turbines. This request was granted by both states.

The U.S. Army Corps of Engineers has been monitoring total dissolved gas in the Columbia River since 1984. A complete record of the TDGmonitoring program for 1994 can be found in a
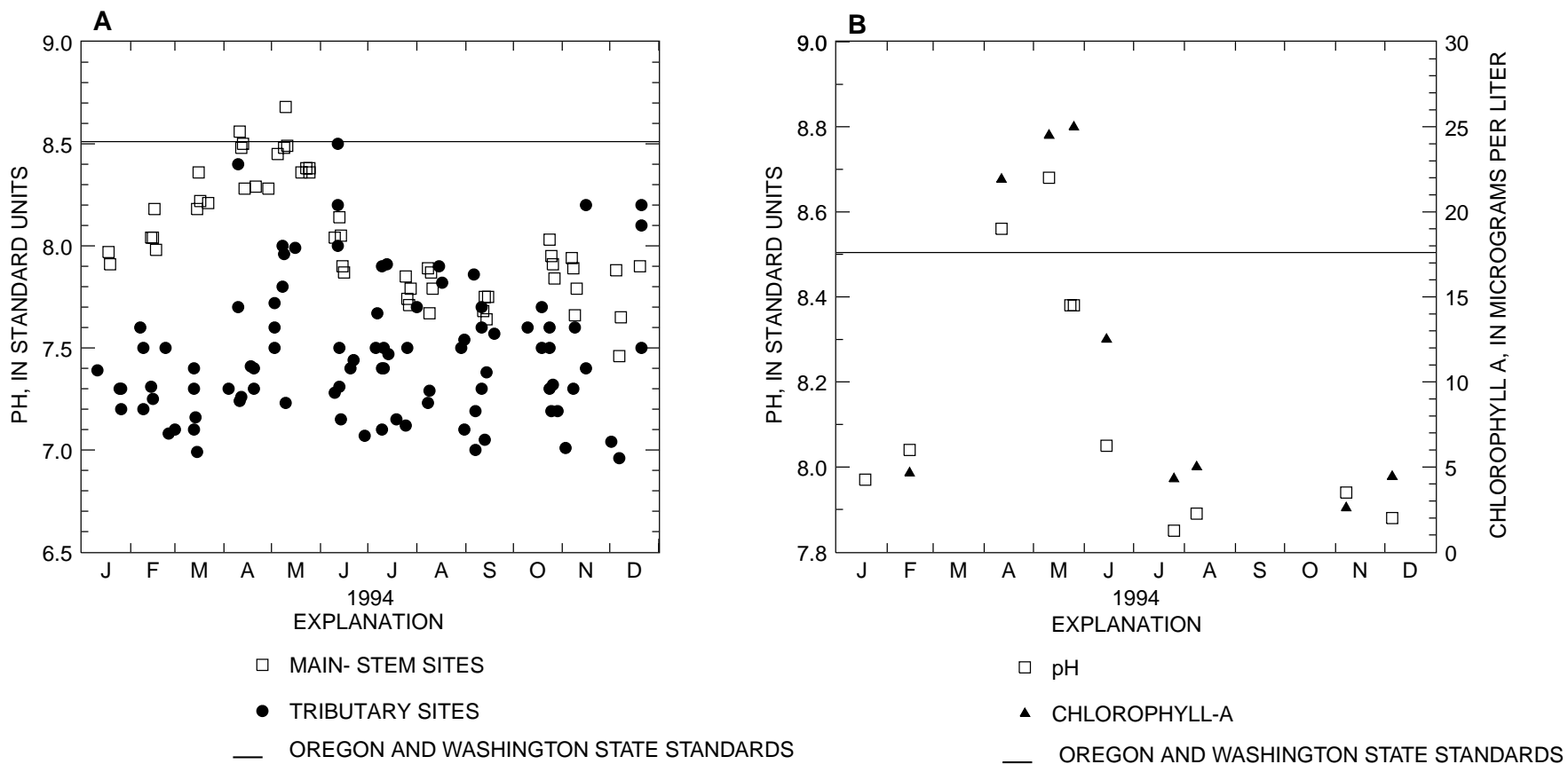

Figure 22. (A) $\mathrm{pH}$ in the main stem and tributaries of the lower Columbia River Basin and (B) chlorophyll-a concentrations in relation to $\mathrm{pH}$ in the Columbia River at river mile 102, downstream from Hayden Island, Oregon and Washington, 1994. 
Table 15. Signs of gas-bubble trauma in salmonids

[Adapted from National Marine Fisheries Service, 1994; \%, percent]

\begin{tabular}{|c|c|c|}
\hline Signs and effects & $\begin{array}{c}\text { Total dissolved gas threshold } \\
\text { (sea level) }\end{array}$ & Age/class \\
\hline Cardiovascular bubbles & acutely lethal at $115-118 \%$ & Juveniles and adults \\
\hline $\begin{array}{l}\text { Subdermal emphysema including lining of } \\
\text { mouth }\end{array}$ & about $110 \%$ & Juveniles and adults \\
\hline Bubbles in lateral line & about $110 \%$ & Juveniles and adults \\
\hline Rupture of swim bladder in small fish & about $110 \%$ & Swim-up fry and juveniles \\
\hline Over inflation of swim bladder in small fish & about $103 \%$ & Swim-up fry and juveniles \\
\hline Exophthalmia and ocular lesions & unknown, $102 \%$ for ocular lesions & Juveniles and adults \\
\hline Bubbles in intestinal tract & 102 to $110 \%$ & Juveniles and adults, larval (physoclistous) \\
\hline Loss of swimming ability & about $106 \%$ & Juveniles and adults \\
\hline Reduced growth & 102 to $105 \%$ (Chinook, lake trout) & Juveniles \\
\hline Immunosuppression (if present) & greater than $108 \%$ & Juveniles and adults \\
\hline Reduced ability to adapt to saltwater & variable & Juveniles \\
\hline
\end{tabular}

report by the U.S. Army Corps of Engineers (1994). In 1994, they operated continuous TDG monitors in the Columbia River at Warrendale (RM 140.5), Skamania (RM 140.6), Camas (RM 122), Kalama (RM 77), and Wauna Mill (RM 42). The TDG data from these sites included values between 100 and 120 percent of saturation during most of the spring and summer of 1994 decreasing in a downstream direction from Bonneville Dam to Wauna Mill. Figure 23 shows TDG concentrations at Warrendale during April through September of 1994 and 198493. The historic high values from April 15 through July 15 were generally caused by spills released at upstream dams because the Columbia River streamflow exceeded the capacity of the hydropower turbines. The higher-than-average values in 1994 that occurred from July 15 through August 20 were the result of requests for the U.S. Army Corps of Engineers to spill water at the dams during 12 hours each night to aid the outmigration of anadromous fish.

The few concentrations of TDG measured by the USGS were similar to the U.S. Army Corps of Engineers data. Generally, the TDG and the dissolved-oxygen concentrations (expressed as percent of saturation) were similar in magnitude. This is to be expected because oxygen makes up a relatively constant proportion of atmospheric gasses, which were the major source of dissolved gas in the lower Columbia River. (Photosynthesis and respiration by aquatic organisms were minimal).

\section{Suspended Sediment}

Suspended-sediment movement in streams is an important factor in the transport and fate of chemicals in the environment. Many contaminants, including nutrients, trace elements, organic compounds, and fecal-indicator bacteria are associated with suspended sediment. Sediment may be transported in the water column or may be deposited on the streambed for a period of time. During the process of transport and deposition, suspended particles often sort themselves such that coarse sand will dominate in one area and fine silt and clay particles in another area. Salinity causes the finest organic particles to coagulate and settle (Thurman, 1985), resulting in areas near the Columbia River mouth that are dominated by very fine sediment. Suspended-sediment concentrations 


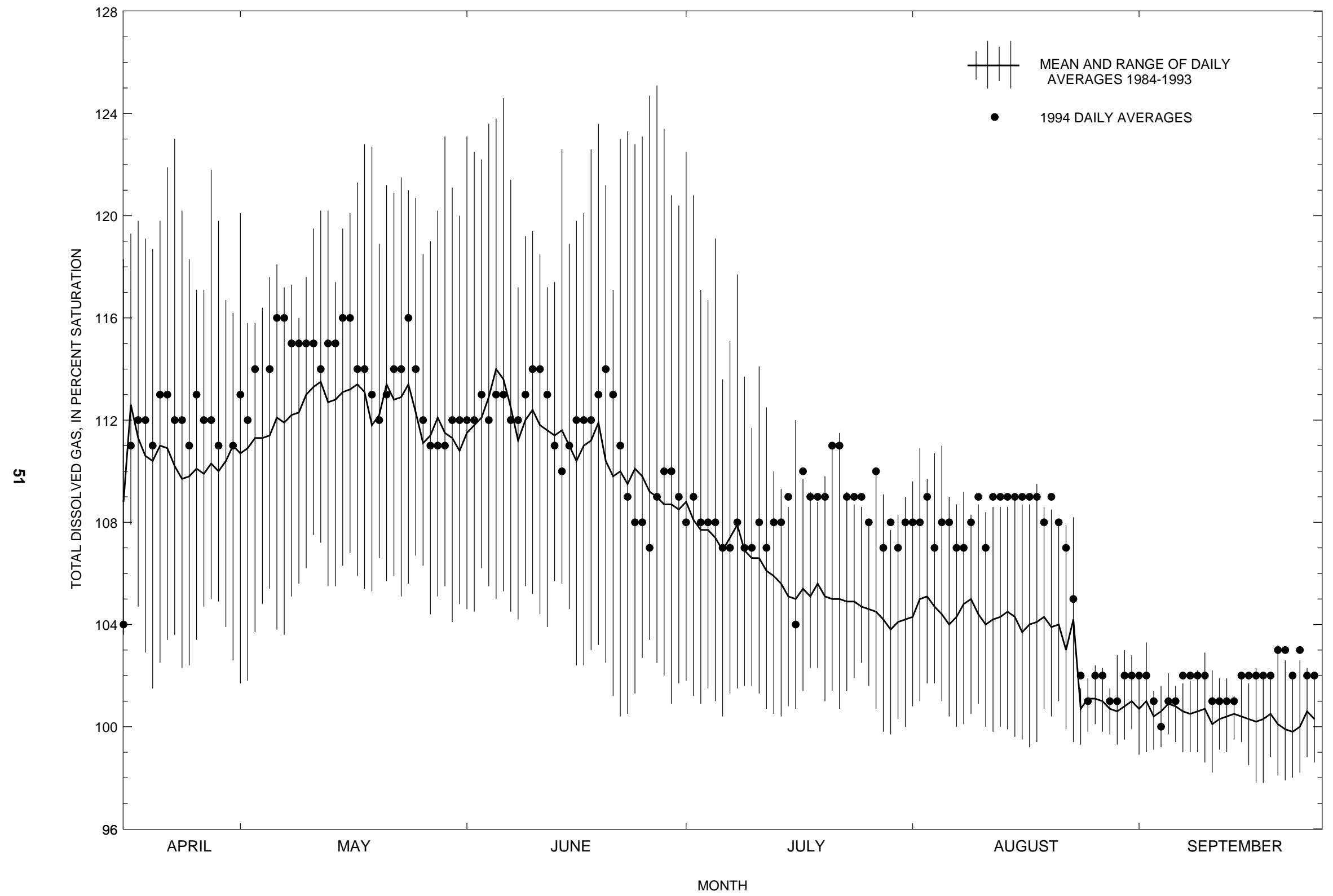

Figure 23. Total dissolved-gas concentrations in the Columbia River at Warrendale, lower Columbia River Basin, Oregon, 1984-93 and 1994. (Source of data: Fis Passage Center, Portland, Oregon, unpub. data, 1995.) 
and associated contaminants can potentially affect water used for domestic-water supplies, aquatic-life propagation, and recreation. High suspendedsediment concentrations often are associated with intense storms that increase streamflows, erosion, and resuspension of bed sediment.

Suspended-sediment concentrations analyzed by State agencies (ODEQ and WDOE) are gravimetric determinations of total suspended solids remaining after drying the sample at $105^{\circ} \mathrm{C}$ (STORET parameter code 00530; U.S. Environmental Protection Agency, 1979), and the USGS analyses are gravimetric determinations of suspended-sediment concentrations remaining after drying the sample at $105^{\circ} \mathrm{C}$ (STORET parameter code 80154; Guy, 1969). The ODEQ samples were generally grab samples from one point in the stream cross section, while the WDOE and USGS samples were depth- and width-integrated samples collected isokinetically relative to stream velocities. The nonfilterable-residue method of determination (total suspended solids) used by the State agencies requires that an aliquot of sample be withdrawn from a well-mixed sample bottle for analysis, whereas the suspended-sediment method of determination requires analysis of the entire contents of sediment and water in a sample container. As a result of differences in sampling and analytical methods among agencies, and on the basis of limited quality-assurance data (see QualityAssurance section of this report), data generated from the two methods may not be comparable; consequently, USGS and State agency data are summarized separately (table 16).

Data from the four sites on the main stem Columbia River indicates that suspended sediment increases in a downstream direction (table 16). The median concentration of suspended sediment in the main stem ranged from $5 \mathrm{mg} / \mathrm{L}$ at Warrendale to $9 \mathrm{mg} / \mathrm{L}$ at Beaver Army Terminal. Maximum suspended-sediment concentrations generally coincided with peak streamflow for the Willamette River at Portland and the Columbia River at Warrendale (fig. 24). The Cowlitz and Willamette Rivers had the largest median suspended sediment concentrations (both were $21 \mathrm{mg} / \mathrm{L}$, from USGS data) of the tributaries to the Columbia River. The Willamette and the Cowlitz Rivers had median suspended-sediment concentrations approximately 5 to 10 times those of the Sandy, Lewis, and Kalama
Rivers. Results of the seasonal Kendall trend test for suspended-sediment concentration, both nonflow adjusted and flow adjusted, indicated no significant ( $\rho$ $<0.05$ ) trends at the Columbia River at Warrendale or the Willamette River at Portland (table 49, at back of report).

Sites with adequate historical data to estimate monthly and annual mean daily loads for suspended sediment were the Columbia River at Warrendale, Columbia River at Beaver Army Terminal, and the Willamette River at Portland (tables 17 and 18). Both the Willamette and Warrendale sites had enough data to estimate loads for a period of about 20 years (1974-94). Three water years from that period were chosen $(1977,1975,1974)$ to represent low-, median-, and high-flow years, respectively. These water years had flows similar to low-, median-, and high-flow water years shown for the period 1928-84 (see fig. 6). The estimated annual loads of suspended sediment for the current year (1994) are similar to the estimated loads for 1977, a low-flow year (table 18).

Load estimates for the lower Columbia River indicate seasonal variation in suspended sediment loads. During the period January through April of 1994, the suspended-sediment loads in the Willamette River plus the loads at Warrendale were greater than the loads at Beaver Army Terminal (table 17). The deficit of suspended sediment at Beaver Army Terminal may indicate deposition in the reach during this period. In contrast, from May to December of 1994, the Columbia River had downstream "net gains" in suspended sediment loads from Warrendale to Beaver Army Terminal, which cannot be accounted for by only inputs from the Willamette River. For example, in June, estimates of mean daily suspendedsediment load indicate that the Columbia River gained 2,300 tons per day between Warrendale and Beaver Army Terminal, while the Willamette River provided only 380 tons per day. The unaccounted-for load may be coming from the Cowlitz River and (or) resuspension in the main stem. Unfortunately, waterquality data were insufficient to calculate loads of suspended sediment on the Cowlitz River using the ESTIMATOR program. However, instantaneous suspended-sediment loads for the Cowlitz River show that the Cowlitz River can produce loads of similar magnitude to those of the Willamette River (101 to 812 tons/day). Therefore, the Cowlitz River may account for a portion of the additional suspendedsediment load at Beaver Army Terminal. Further, the 
Table 16. Distribution of suspended-sediment and suspended-solids concentrations, lower Columbia River Basin, Oregon and Washington, 1994 [To avoid statistical bias that may be associated with constituents analyzed more than once at a site only one concentration per month was statistically summarized; see table 7 for full site names; concentrations are reported in milligrams per liter; -- indicates fewer than 5 samples collected, therefore percentile not calculated]

\begin{tabular}{|c|c|c|c|c|c|c|c|}
\hline \multirow{2}{*}{ Site name } & \multirow{2}{*}{ Agency } & \multirow{2}{*}{$\begin{array}{l}\text { Number of } \\
\text { samples }\end{array}$} & \multirow{2}{*}{$\begin{array}{l}\text { Minimum } \\
\text { value }\end{array}$} & \multicolumn{3}{|c|}{$\begin{array}{l}\text { Value at indicated } \\
\text { percentile }\end{array}$} & \multirow{2}{*}{$\begin{array}{l}\text { Maximum } \\
\text { value }\end{array}$} \\
\hline & & & & 25 & 50 & 75 & \\
\hline Columbia River at Warrendale & USGS & 11 & 3 & 4 & 5 & 7 & 12 \\
\hline Columbia River at Hayden Island & USGS & 12 & 1 & 5 & 7 & 8 & 15 \\
\hline Columbia River near Columbia City & USGS & 12 & 5 & 5 & 9 & 15 & 18 \\
\hline Columbia River at Beaver Army Terminal & USGS & 11 & 5 & 8 & 9 & 16 & 21 \\
\hline Sandy River & USGS & 4 & 2 & -- & 3 & -- & 8 \\
\hline Sandy River & ODEQ & 11 & $<1$ & 2 & 4 & 6 & 10 \\
\hline Willamette River at Portland & USGS & 12 & 5 & 10 & 21 & 70 & 146 \\
\hline Willamette River at Portland & ODEQ & 11 & 2 & 4 & 5 & 6 & 24 \\
\hline Lewis River & USGS & 4 & 1 & -- & 2 & -- & 3 \\
\hline Lewis River & WDOE & 10 & 1 & 2 & 4 & 6 & 10 \\
\hline Multnomah Channel & USGS & 11 & 7 & 9 & 11 & 17 & 25 \\
\hline Kalama River & USGS & 4 & 2 & -- & 4 & -- & 8 \\
\hline Kalama River & WDOE & 10 & 1 & 3 & 4 & 8 & 26 \\
\hline Cowlitz River & USGS & 4 & 7 & -- & 21 & -- & 36 \\
\hline Cowlitz River & WDOE & 10 & 2 & 6 & 7 & 28 & 391 \\
\hline
\end{tabular}




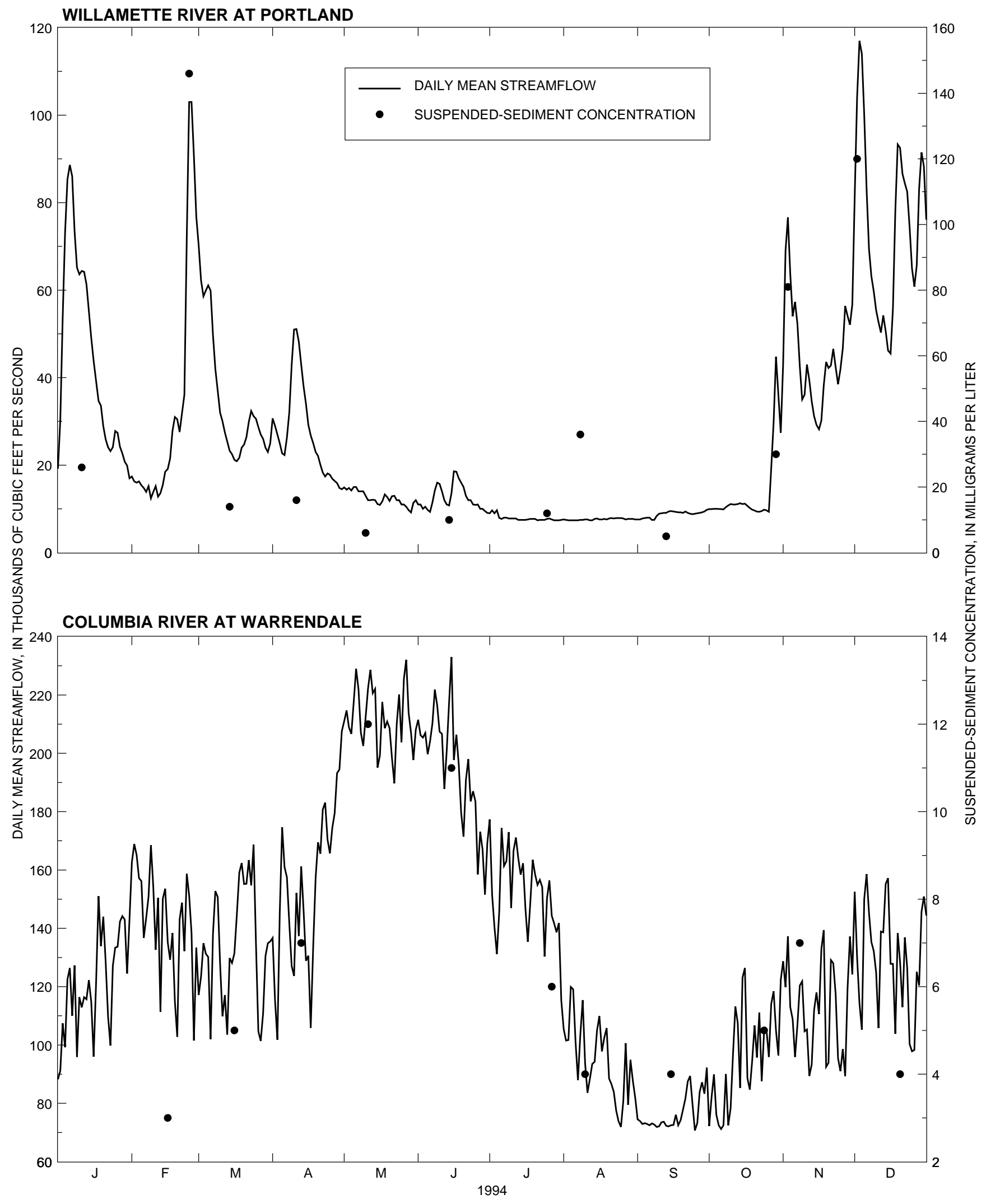

Figure 24. Relation between daily mean streamflow and suspended-sediment concentrations in the Willamette River at Portland and Columbia River at Warrendale, lower Columbia River Basin, Oregon, 1994. 
Table 17. Calculated monthly and annual mean daily loads for suspended sediment at selected sites, lower Columbia River Basin, Oregon, 1994

[See table 7 for full site names; loads are reported in tons per day; -, minus; all mean daily loads were calculated using ESTIMATOR (Cohn and others, 1992)]

\begin{tabular}{l|ccc|c|c}
\hline \multicolumn{1}{c|}{ Month } & Warrendale & Willamette & Beaver & $\begin{array}{c}\text { Net gain } \\
\text { (Beaver - Warrendale) }\end{array}$ & $\begin{array}{c}\text { Unaccounted-for load } \\
\text { (Net gain - Willamette) }\end{array}$ \\
\hline January & 3,900 & 2,800 & 5,000 & 1,100 & $-1,700$ \\
February & 5,900 & 1,800 & 6,100 & 200 & $-1,600$ \\
March & 5,900 & 1,600 & 6,500 & 600 & $-1,000$ \\
April & 7,500 & 1,100 & 7,700 & 200 & -900 \\
May & 11,000 & 330 & 12,000 & 1,000 & 670 \\
June & 8,700 & 380 & 11,000 & 2,300 & 1,900 \\
July & 4,900 & 200 & 6,700 & 1,800 & 1,600 \\
August & 2,000 & 200 & 2,700 & 700 & 500 \\
September & 1,200 & 260 & 1,700 & 500 & 240 \\
October & 1,800 & 590 & 2,700 & 900 & 310 \\
November & 2,400 & 3,500 & 6,700 & 4,300 & 800 \\
December & 3,600 & 6,900 & 13,000 & 9,400 & 3,500 \\
\hline \hline \multicolumn{1}{c}{ Annual } & 4,900 & 1,600 & 6,800 & 1,900 & 300 \\
\hline
\end{tabular}

higher flows in the Columbia River during May, June, and July (fig. 8) may provide the energy necessary to resuspend streambed sediment and supply the additional load at Beaver Army Terminal. Resuspension probably is greatest from May through July and in December.

\section{Nutrients}

Historical data show that nutrient concentrations are relatively low in the lower Columbia River Basin. Nutrient concentrations measured in 1994 were compared with historical data (1964-93) from the lower Columbia River Basin and data from 300 sites on rivers across the United States (table 19). The 1994 median concentration of phosphorus in unfiltered water is much smaller in the lower Columbia River Basin $(0.03 \mathrm{mg} / \mathrm{L})$ than the median for rivers across the United States $(0.17 \mathrm{mg} / \mathrm{L})$. Nitrite-plus-nitrate concentrations in filtered water have a similar pattern, with a 1994-median concentration of 0.17 $\mathrm{mg} / \mathrm{L}$ in the lower Columbia River Basin compared to $0.71 \mathrm{mg} / \mathrm{L}$ for rivers across the United States. The historical concentrations of nutrients in the lower Columbia River Basin were generally twice as large as the current concentrations. Differences between the historical and current data likely are due to the predominance of data from the Willamette River Basin in the historical database, rather than a waterquality trend.

The Willamette River is affected by many municipal and agricultural sources, whereas much of the rest of the lower Columbia River Basin is chiefly forest lands (fig. 9). As a result, historical concentrations of nutrients are higher in the Willamette River Basin when compared with those in other areas of the lower Columbia River Basin. This pattern is apparent when the 90th-percentile concentrations for phosphorus in unfiltered water and nitrite plus nitrate and ammonia in filtered water are compared by geographical areas (fig. 25). By 
Table 18. Calculated monthly and annual mean daily suspended-sediment loads for the current water year and low, median, and high streamflow water years in the Columbia River at Warrendale and Willamette River at Portland, lower Columbia River Basin, Oregon

[See table 7 for full site name; loads are reported in tons per day; all mean daily loads were calculated using ESTIMATOR (Cohn and others, 1992); see the "Streamflow Conditions" section for a description of flow-year designations]

\begin{tabular}{|c|c|c|c|c|c|c|c|c|}
\hline \multirow{2}{*}{ Month } & \multicolumn{2}{|c|}{$\begin{array}{c}1977 \\
\text { Low streamflow year }\end{array}$} & \multicolumn{2}{|c|}{$\begin{array}{c}1975 \\
\text { Median streamflow year }\end{array}$} & \multicolumn{2}{|c|}{$\begin{array}{c}1974 \\
\text { High streamflow year }\end{array}$} & \multicolumn{2}{|c|}{$\begin{array}{c}1994 \\
\text { Current year }\end{array}$} \\
\hline & Warrendale & Willamette & Warrendale & Willamette & Warrendale & Willamette & Warrendale & Willamette \\
\hline October & 3,500 & 540 & 3,000 & 590 & 2,200 & 510 & 2,000 & 570 \\
\hline November & 3,400 & 520 & 3,400 & 1,100 & 3,000 & 13,000 & 2,400 & 370 \\
\hline December & 4,100 & 200 & 4,200 & 5,700 & 6,300 & 16,000 & 2,900 & 1,600 \\
\hline January & 5,700 & 170 & 6,900 & 8,200 & 14,000 & 14,000 & 3,900 & 2,800 \\
\hline February & 5,000 & 150 & 9,200 & 3,900 & 14,000 & 5,500 & 5,900 & 1,800 \\
\hline March & 5,600 & 1,200 & 13,000 & 3,800 & 14,000 & 5,900 & 5,900 & 1,600 \\
\hline April & 4,500 & 530 & 13,000 & 1,200 & 22,000 & 4,200 & 7,500 & 1,100 \\
\hline May & 6,000 & 870 & 21,000 & 1,600 & 26,000 & 1,400 & 11,000 & 330 \\
\hline June & 4,700 & 440 & 19,000 & 660 & 33,000 & 1,600 & 8,700 & 380 \\
\hline July & 2,300 & 180 & 8,300 & 330 & 15,000 & 390 & 4,900 & 200 \\
\hline August & 2,100 & 220 & 3,500 & 290 & 5,100 & 200 & 2,000 & 200 \\
\hline September & 2,000 & 440 & 2,400 & 540 & 3,200 & 290 & 1,200 & 260 \\
\hline Annual & 4,100 & 460 & 8,900 & 2,300 & 13,000 & 5,300 & 4,900 & 940 \\
\hline
\end{tabular}


Table 19. Comparison of nutrient concentrations in water in the lower Columbia River Basin to surface waters of the United States

[The term "filtered water" is an operational definition referring to the chemical analysis of that portion of a water-suspended sediment sample that passes through a nominal 0.45 -

micrometer filter; conversely, the term "unfiltered water" refers to the chemical analysis of a water sample that has not been filtered or centrifuged, nor in any way altered from the original matrix; to avoid statistical bias that may be associated with constituents analyzed more than once at a site, only one value per month per agency was statistically summarized; data for ammonia plus organic nitrogen in filtered water, nitrite in filtered water, and phosphorus in filtered water are not included in this table due to lack of historical comparative data; values are reported in milligrams per liter as nitrogen or phosphorus; NASQAN, National Stream Accounting Network based on data from 300 sites across the United States; --, no data; <, less than; USGS, U.S. Geological Survey; ODEQ, Oregon Department of Environmental Quality; data for orthophosphate in filtered water from Washington Department of Ecology are not summarized because all data were below the method reporting limit of 0.01 milligrams per liter]

\begin{tabular}{|c|c|c|c|c|c|c|c|c|c|c|c|c|c|}
\hline \multirow{3}{*}{ Constituent name } & \multirow{2}{*}{\multicolumn{3}{|c|}{$\begin{array}{c}\text { NASQAN } \\
1974-81^{\mathrm{a}} \\
\begin{array}{c}\text { Value at indicated } \\
\text { percentile }\end{array}\end{array}$}} & \multicolumn{5}{|c|}{ Lower Columbia River Basin (1964-93) } & \multicolumn{5}{|c|}{ Lower Columbia River Basin (1994) } \\
\hline & & & & \multirow{2}{*}{$\begin{array}{c}\text { Number } \\
\text { of } \\
\text { samples }\end{array}$} & \multicolumn{4}{|c|}{ Value at indicated percentile } & \multirow{2}{*}{$\begin{array}{c}\text { Number } \\
\text { of } \\
\text { samples }\end{array}$} & \multicolumn{4}{|c|}{ Value at indicated percentile } \\
\hline & 25 & 50 & 75 & & 25 & 50 & 75 & 90 & & 25 & 50 & 75 & 90 \\
\hline Ammonia, filtered water & -- & -- & -- & 1,711 & 0.01 & 0.03 & 0.09 & 0.41 & 84 & 0.02 & 0.03 & 0.05 & 0.08 \\
\hline Ammonia plus organic nitrogen, unfiltered water & -- & -- & -- & 8,945 & .2 & .3 & 6 & 1.1 & 94 & $<.2$ & $<.2$ & .3 & .4 \\
\hline Nitrite plus nitrate, filtered water & 0.43 & 0.71 & 1.1 & 1,122 & .10 & .37 & 1.2 & 2.5 & 84 & .06 & .17 & .34 & .74 \\
\hline Phosphorus, unfiltered water & .11 & .17 & .27 & 10,927 & .04 & .07 & .15 & .30 & 114 & .02 & .03 & .04 & .08 \\
\hline Orthophosphate, filtered water (USGS data only) & -- & -- & -- & 9,051 & .010 & .027 & .060 & .152 & 84 & .003 & .012 & .023 & .040 \\
\hline Orthophosphate, filtered water (ODEQ data only) & -- & -- & -- & 9,051 & .010 & .027 & .060 & .152 & 21 & .006 & .036 & .054 & .068 \\
\hline
\end{tabular}

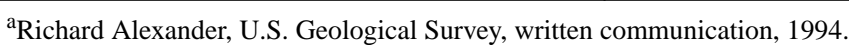

bU.S. Environmental Protection Agency's STOrage and RETrieval system (STORET), U.S. Geological Survey's National Water Information System (NWIS), and Tetra Tech, Inc., Redmond, Washington, unpub. data, 1994. 


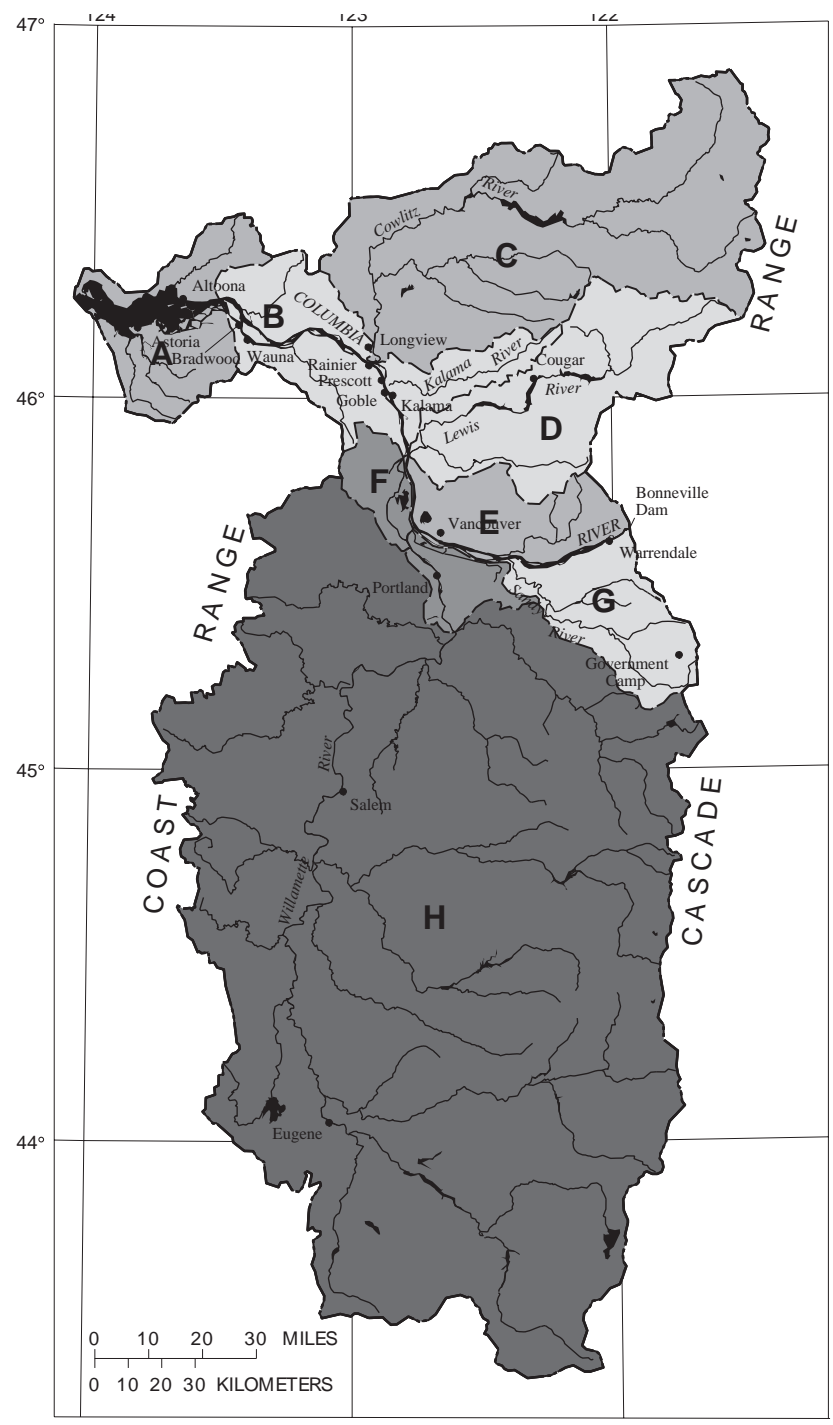

EXPLANATION

Less than 0.1 milligrams per liter

More than or equal to 0.1 and less than 0.2 milligrams per liter

More than or equal to 0.2 and less than 0.3 milligrams per liter

More than or equal to 0.3 milligrams per liter

Subbasin or u nit border

Basin border

A Subbasin or unit name

\begin{tabular}{clc}
$\begin{array}{c}\text { Map } \\
\text { Symbol }\end{array}$ & \multicolumn{1}{c}{ Subbasin or unit name } & $\begin{array}{c}\text { Number of } \\
\text { samples }\end{array}$ \\
\hline A & Lower Columbia (estuary) Unit & 82 \\
B & Lower Columiba-Clatskanie & 553 \\
C & Cowlitz River Subbasin & 707 \\
D & Lewis River Subbasin & 248 \\
E & Lower Columbia-Sandy, Washington & 182 \\
F & Lower Willamette Unit & 1202 \\
G & Lower Columbia-Sandy, Oregon & 729 \\
H & Willamette River Subbasin & 7166
\end{tabular}

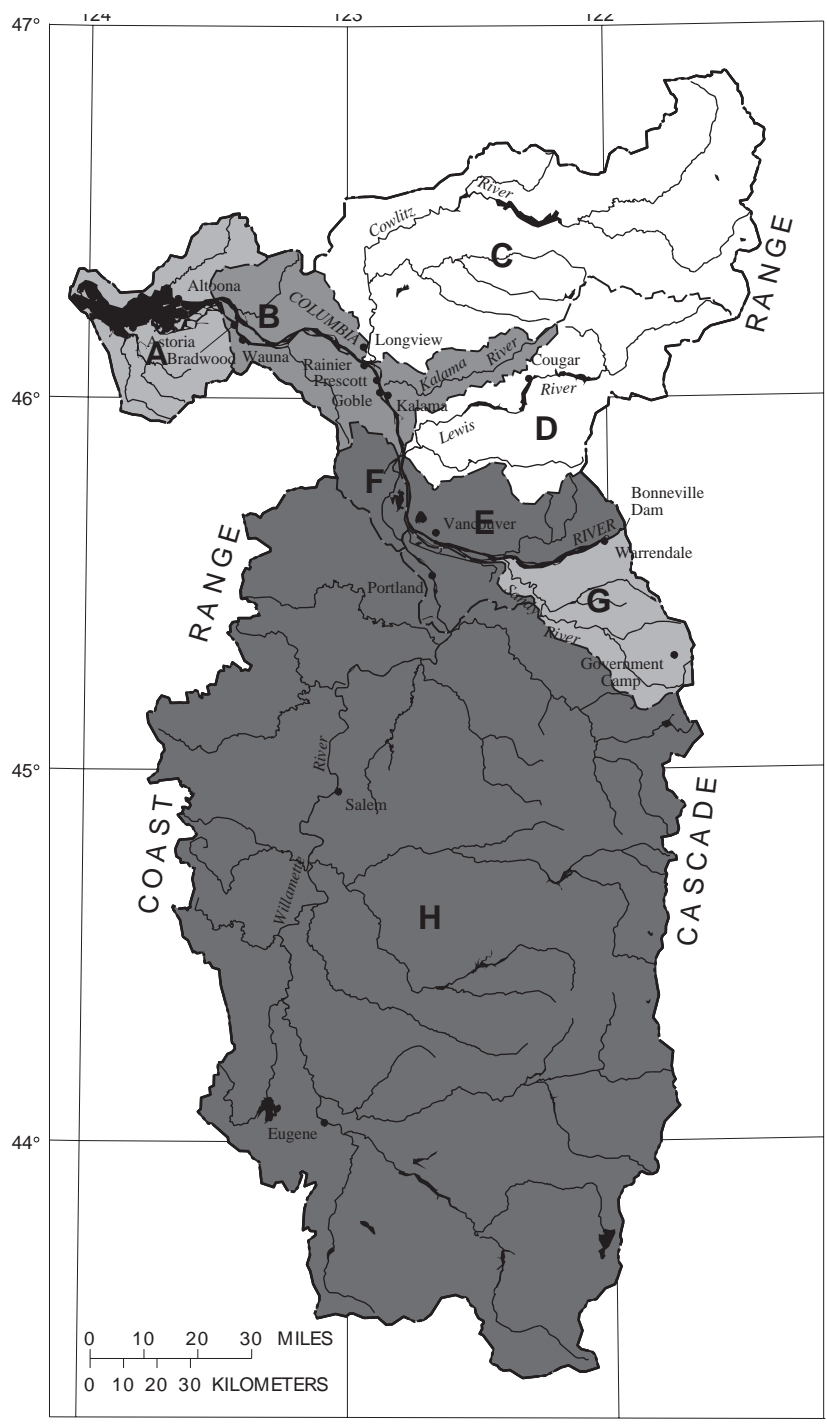

EXPLANATION

Nitrite plus nitrate

Insufficient data

Less than 0.5 milligrams per liter

More than or equal to 0.5 and less than 1.0 milligrams per liter

More than or equal to 2.0 milligrams per liter

- Subbasin or u nit border

Basin border

A Subbasin or unit name

\begin{tabular}{clc}
$\begin{array}{c}\text { Map } \\
\text { Symbol }\end{array}$ & \multicolumn{1}{c}{ Subbasin or unit name } & $\begin{array}{c}\text { Number of } \\
\text { samples }\end{array}$ \\
\hline A & Lower Columbia (estuary) Unit & 29 \\
B & Lower Columiba-Clatskanie & 55 \\
C & Cowlitz River Subbasin & insufficient data \\
D & Lewis River Subbasin & insufficient data \\
E & Lower Columbia-Sandy, Washington & 17 \\
F & Lower Willamette Unit & 176 \\
G & Lower Columbia-Sandy, Oregon & 107 \\
H & Willamette River Subbasin & 639
\end{tabular}




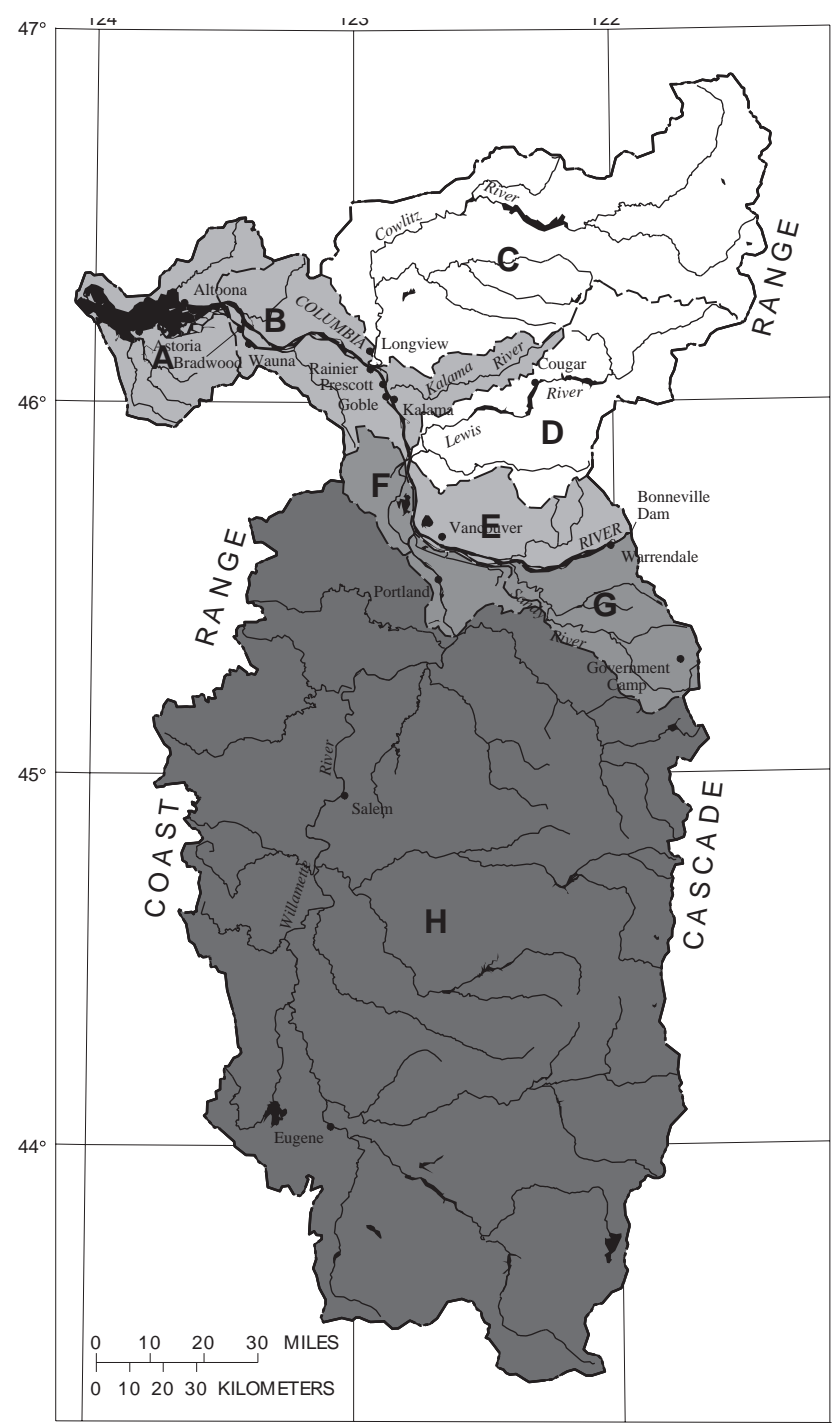

EXPLANATION

Ammonia

Insufficient Data

Less than 0.1 milligram per liter

More than or equal to 0.1 and less than 0.2 milligram per liter

More than or equal to 0.5 milligram per liter

- Subbasin or u nit border

- Basin border

A Subbasin or unit name

\begin{tabular}{clc}
$\begin{array}{c}\text { Map } \\
\text { Symbol }\end{array}$ & \multicolumn{1}{c}{ Subbasin or unit name } & $\begin{array}{c}\text { Number of } \\
\text { samples }\end{array}$ \\
\hline A & Lower Columbia (estuary) Unit & 8 \\
B & Lower Columiba-Clatskanie & 56 \\
C & Cowlitz River Subbasin & insufficient data \\
D & Lewis River Subbasin & insufficient data \\
E & Lower Columbia-Sandy, Washington & 13 \\
F & Lower Willamette Unit & 190 \\
G & Lower Columbia-Sandy, Oregon & 94 \\
H & Willamette River Subbasin & 967
\end{tabular}

Figure 25. Spatial distribution of 90th-percentile values for phosphorus concentrations in unfiltered water and nitrite plus nitrate and ammonia in filtered water by subbasin or unit, lower Columbia River Basin, Oregon and Washington, 1964-93.

showing the 90th percentiles of all historical data sampled in each subbasin or unit, figure 25 indicates which subbasins or units of the lower Columbia River Basin had comparatively low, medium, or high historical nutrient concentrations. The historical data were grouped into subbasins and units for statistical purposes only; these maps do not imply that the indicated nutrient concentration existed everywhere in a given unit. The maps do show in a general way the historical nutrient concentrations of different areas of the lower Columbia River Basin, as recorded by the sampling done. Detailed historical nutrient data are not presented, however, because the sampling methods and quality of data are unknown.

Current data for nutrient concentrations show that the Willamette River is a significant source of nutrients in the lower Columbia River Basin. In 1994, samples were collected and analyzed for phosphorus and ammonia plus organic nitrogen in unfiltered water and ammonia, nitrite plus nitrate, and orthophosphate in filtered water. The median concentration for each of the five species was largest at the Willamette River at Portland sampling site (table 20). When ranking the median concentrations from highest to lowest, the same general order of concentrations was followed at all sampling sites for all of the constituents analyzed:

Willamette River > Multnomah Channel > Columbia River sites downstream of the Willamette River $>$ Columbia River sites upstream of the Willamette River > other tributaries.

Concentrations of ammonia and ammonia plus organic nitrogen were usually near the method reporting limit.

Seasonal variations in nutrient concentrations were apparent in 1994. Phosphorus concentrations in unfiltered water in the Willamette River at Portland were highest from November to February, during periods of winter-storm activity (fig. 26). In contrast, a large seasonal variation was not observed in phosphorus in the Columbia River at Hayden Island (RM 102) and Columbia River near Columbia City (RM 84). All three sites had variation, however, in concentrations of nitrite plus nitrate in filtered water. The highest concentrations in the Willamette River 
Table 20. Distribution of nutrient concentrations in water, lower Columbia River Basin, Oregon and Washington, 1994

[The term "filtered water" is an operational definition referring to the chemical analysis of that portion of a water-suspended sediment sample that passes through a nominal 0.45-micrometer filter; conversely, the term "unfiltered water" refers tot he chemical analysis of a water sample that has not been filtered or centrifuged, nor in any way altered from the original matrix; to avoid statistical bias that may be associated with constituents analyzed more than once at a site, only one concentration per month per agency was statistically summarized; values are reported in milligrams per liter as nitrogen or phosphorus; see table 7 for full site names; USGS, U.S. Geological Survey; ODEQ, Oregon Department of Environmental Quality; WDOE, Washington Department of Ecology; <, less than; --, fewer than 5 samples collected, therefore percentile not calculated; for orthophosphate, different reporting limits were used by different agencies]

\begin{tabular}{|c|c|c|c|c|c|c|c|}
\hline \multirow{2}{*}{ Site name } & \multirow{2}{*}{$\begin{array}{c}\text { Agenc } \\
y\end{array}$} & \multirow{2}{*}{$\begin{array}{c}\text { Number } \\
\text { of samples }\end{array}$} & \multirow{2}{*}{$\begin{array}{l}\text { Minimum } \\
\text { value }\end{array}$} & \multicolumn{3}{|c|}{$\begin{array}{l}\text { Value at indicated } \\
\text { percentile }\end{array}$} & \multirow{2}{*}{$\begin{array}{l}\text { Maximum } \\
\text { value }\end{array}$} \\
\hline & & & & 25 & 50 & 75 & \\
\hline \multicolumn{8}{|c|}{ Ammonia, filtered water } \\
\hline Columbia River at Warrendale & USGS & 11 & $<0.01$ & 0.01 & 0.02 & 0.03 & 0.06 \\
\hline Columbia River at Hayden Island & USGS & 12 & .01 & .02 & .03 & .05 & .09 \\
\hline Columbia River near Columbia City & USGS & 12 & .01 & .02 & .03 & .04 & .07 \\
\hline Columbia River at Beaver Army Terminal & USGS & 11 & .02 & .02 & .03 & .04 & .06 \\
\hline Willamette River at Portland & USGS & 12 & .04 & .05 & .06 & .09 & .12 \\
\hline Multnomah Channel near mouth & USGS & 11 & $<.01$ & .02 & .03 & .07 & .13 \\
\hline Sandy River near Troutdale & USGS & 4 & $<.01$ & -- & .01 & -- & .02 \\
\hline Lewis River at Woodland & USGS & 4 & .01 & -- & .01 & -- & .02 \\
\hline Kalama River near Kalama & USGS & 4 & .01 & -- & .02 & -- & .03 \\
\hline Cowlitz River at Kelso & USGS & 3 & $<.01$ & -- & $<.01$ & -- & .01 \\
\hline \multicolumn{8}{|c|}{ Ammonia plus organic nitrogen, unfiltered water } \\
\hline Columbia River at Warrendale & USGS & 11 & $<.2$ & $<.2$ & $<.2$ & $<.2$ & .3 \\
\hline Columbia River at Hayden Island & USGS & 12 & $<.2$ & $<.2$ & $<.2$ & .2 & .3 \\
\hline Columbia River near Columbia City & USGS & 12 & $<.2$ & $<.2$ & $<.2$ & .2 & .5 \\
\hline Columbia River at Beaver Army Terminal & USGS & 11 & $<.2$ & $<.2$ & $<.2$ & .3 & .5 \\
\hline Willamette River at Portland & USGS & 12 & $<.2$ & .2 & .3 & .5 & .5 \\
\hline Willamette River at Portland & ODEQ & 11 & $<.2$ & .3 & .4 & .4 & .7 \\
\hline Multnomah Channel near mouth & USGS & 11 & $<.2$ & $<.2$ & .2 & .3 & .3 \\
\hline Sandy River near Troutdale & USGS & 4 & $<.2$ & -- & $<.2$ & -- & $<.2$ \\
\hline Sandy River near Troutdale & ODEQ & 11 & $<.2$ & $<.2$ & .2 & .2 & .4 \\
\hline Lewis River at Woodland & USGS & 4 & $<.2$ & -- & $<.2$ & -- & $<.2$ \\
\hline Kalama River near Kalama & USGS & 4 & $<.2$ & -- & $<.2$ & -- & $<.2$ \\
\hline Cowlitz River at Kelso & USGS & 3 & $<.2$ & -- & $<.2$ & -- & $<.2$ \\
\hline \multicolumn{8}{|c|}{ Nitrite plus nitrate, filtered water } \\
\hline Columbia River at Warrendale & USGS & 11 & $<.05$ & $<.05$ & .16 & .22 & .42 \\
\hline Columbia River at Hayden Island & USGS & 12 & $<.05$ & .05 & .11 & .32 & .73 \\
\hline Columbia River near Columbia City & USGS & 12 & $<.05$ & .07 & .18 & .37 & .56 \\
\hline Columbia River at Beaver Army Terminal & USGS & 11 & $<.05$ & .09 & .17 & .35 & .47 \\
\hline Willamette River at Portland & USGS & 12 & .23 & .30 & .70 & .97 & 1.4 \\
\hline Multnomah Channel near mouth & USGS & 11 & .05 & .13 & .24 & .42 & 1.1 \\
\hline Sandy River near Troutdale & USGS & 4 & $<.05$ & -- & .04 & -- & .07 \\
\hline Lewis River at Woodland & USGS & 4 & $<.05$ & -- & $<.05$ & -- & .31 \\
\hline Kalama River near Kalama & USGS & 4 & 0.06 & -- & 0.07 & -- & 0.12 \\
\hline Cowlitz River at Kelso & USGS & 3 & .06 & -- & .08 & -- & .15 \\
\hline
\end{tabular}


Table 20. Distribution of nutrient concentrations in water, lower Columbia River Basin, Oregon and Washington, 1994-Continued [The term "filtered water" is an operational definition referring to the chemical analysis of that portion of a water-suspended sediment sample that passes through a nominal 0.45-micrometer filter; conversely, the term "unfiltered water" refers tot he chemical analysis of a water sample that has not been filtered or centrifuged, nor in any way altered from the original matrix; to avoid statistical bias that may be associated with constituents analyzed more than once at a site, only one concentration per month per agency was statistically summarized; values are reported in milligrams per liter as nitrogen or phosphorus; see table 7 for full site names; USGS, U.S. Geological Survey; ODEQ, Oregon Department of Environmental Quality; WDOE, Washington Department of Ecology; <, less than; --, fewer than 5 samples collected, therefore percentile not calculated; for orthophosphate, different reporting limits were used by different agencies]

\begin{tabular}{|c|c|c|c|c|c|c|c|}
\hline \multirow{2}{*}{ Site name } & \multirow{2}{*}{$\begin{array}{c}\text { Agenc } \\
y\end{array}$} & \multirow{2}{*}{$\begin{array}{c}\text { Number } \\
\text { of samples }\end{array}$} & \multirow{2}{*}{$\begin{array}{l}\text { Minimum } \\
\text { value }\end{array}$} & \multicolumn{3}{|c|}{$\begin{array}{l}\text { Value at indicated } \\
\text { percentile }\end{array}$} & \multirow{2}{*}{$\begin{array}{l}\text { Maximum } \\
\text { value }\end{array}$} \\
\hline & & & & 25 & 50 & 75 & \\
\hline \multicolumn{8}{|c|}{ Orthophosphate, filtered water } \\
\hline Columbia River at Warrendale & USGS & 11 & .001 & 0.002 & .010 & 0.013 & .017 \\
\hline Columbia River at Hayden Island & USGS & 12 & .002 & .007 & .012 & .015 & .042 \\
\hline Columbia River near Columbia City & USGS & 12 & .001 & .003 & .013 & .018 & .030 \\
\hline Columbia River at Beaver Army Terminal & USGS & 11 & .004 & .005 & .016 & .020 & .024 \\
\hline Willamette River at Portland & USGS & 12 & .010 & .031 & .040 & .060 & .070 \\
\hline Willamette River at Portland & ODEQ & 11 & .036 & .041 & .054 & .065 & .069 \\
\hline Multnomah Channel near mouth & USGS & 11 & .003 & .011 & .029 & .041 & .049 \\
\hline Sandy River near Troutdale & USGS & 4 & .002 & -- & .004 & -- & .007 \\
\hline Sandy River near Troutdale & ODEQ & 10 & $<.005$ & $<.005$ & .006 & .007 & .010 \\
\hline Lewis River at Woodland & USGS & 4 & $<.001$ & -- & .001 & -- & .002 \\
\hline Lewis River at Woodland & WDOE & 10 & $<.01$ & $<.01$ & $<.01$ & $<.01$ & $<.01$ \\
\hline Kalama River near Kalama & USGS & 4 & .006 & -- & .008 & -- & .008 \\
\hline Kalama River near Kalama & WDOE & 10 & $<.01$ & $<.01$ & $<.01$ & $<.01$ & $<.01$ \\
\hline Cowlitz River at Kelso & USGS & 3 & .001 & -- & .001 & -- & .002 \\
\hline Cowlitz River at Kelso & WDOE & 10 & $<.01$ & $<.01$ & $<.01$ & $<.01$ & $<.01$ \\
\hline \multicolumn{8}{|c|}{ Phosphorus, unfiltered water } \\
\hline Columbia River at Warrendale & USGS & 11 & $<.01$ & .02 & .02 & .04 & .04 \\
\hline Columbia River at Hayden Island & USGS & 12 & .02 & .03 & .03 & .04 & .05 \\
\hline Columbia River near Columbia City & USGS & 12 & .02 & .03 & .04 & .04 & .05 \\
\hline Columbia River at Beaver Army Terminal & USGS & 11 & .02 & .03 & .04 & .04 & .06 \\
\hline Willamette River at Portland & USGS & 12 & .05 & .07 & .09 & .14 & .24 \\
\hline Willamette River at Portland & ODEQ & 11 & .06 & .08 & .09 & .11 & .16 \\
\hline Multnomah Channel near mouth & USGS & 11 & .02 & .03 & .06 & .08 & .09 \\
\hline Sandy River near Troutdale & USGS & 4 & $<.01$ & -- & $<.01$ & -- & .02 \\
\hline Sandy River near Troutdale & ODEQ & 10 & $<.01$ & .01 & .02 & .02 & .03 \\
\hline Lewis River at Woodland & USGS & 4 & $<.01$ & -- & $<.01$ & -- & .02 \\
\hline Lewis River at Woodland & WDOE & 10 & $<.01$ & $<.01$ & .01 & .02 & .02 \\
\hline Kalama River near Kalama & USGS & 4 & $<.01$ & -- & .01 & -- & .02 \\
\hline Kalama River near Kalama & WDOE & 10 & $<.01$ & .01 & .02 & .02 & .03 \\
\hline Cowlitz River at Kelso & USGS & 3 & $<.01$ & -- & .01 & -- & .02 \\
\hline Cowlitz River at Kelso & WDOE & 10 & $<.01$ & $<.01$ & .02 & .04 & .08 \\
\hline
\end{tabular}



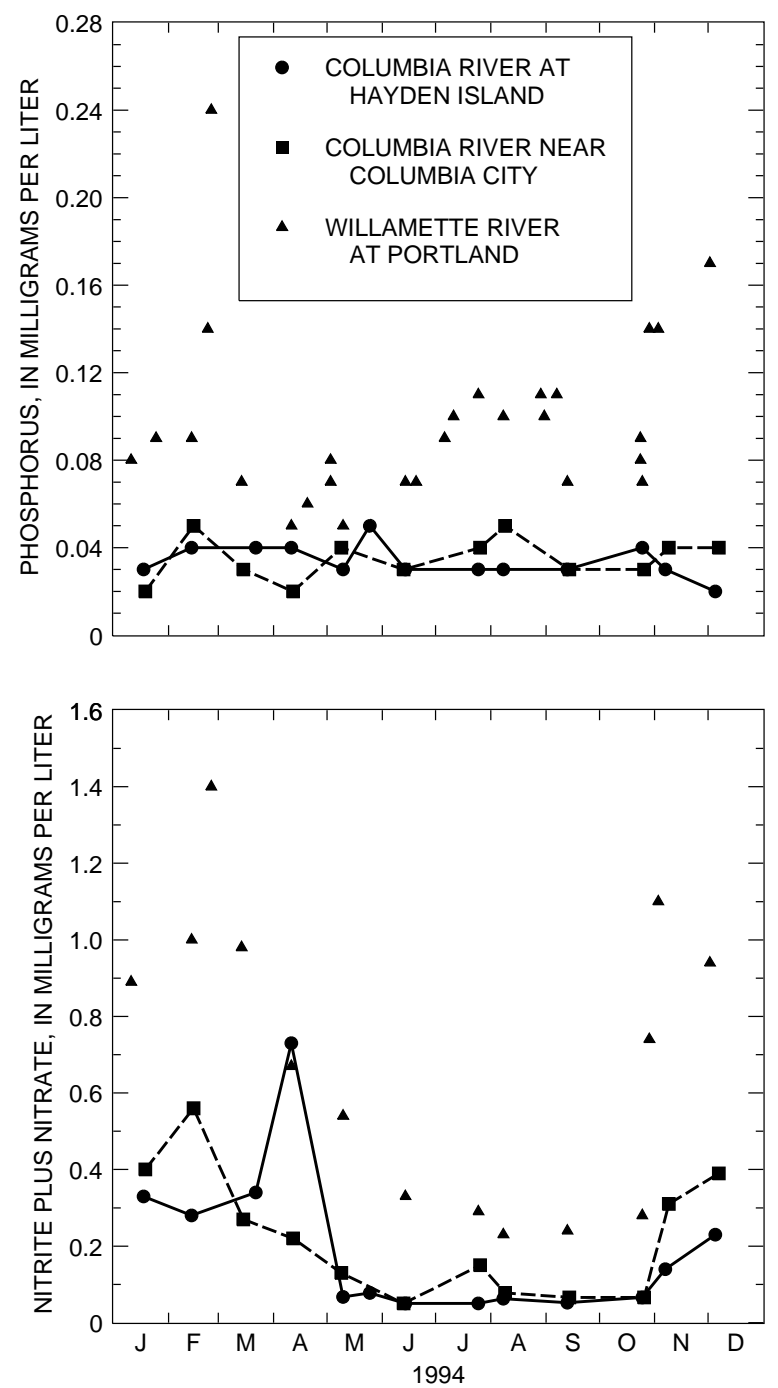

Figure 26. Concentrations of phosphorus in unfiltered water and nitrite plus nitrate in filtered water in the Columbia River at Hayden Island, Willamette River at Portland, and Columbia River near Columbia City, lower Columbia River Basin, Oregon and Washington, 1994.

and Columbia River near Columbia City occurred during the period of November to March, whereas the highest concentrations in the Columbia River at Hayden Island occurred in March and April. This difference in peaks on the Columbia River was probably due to the influence of the Willamette River. During these periods of colder temperatures and less light, nitrogen uptake by algae is decreased, therefore, the nitrogen concentration in the Columbia River is increased. As expected, the concentrations then decrease during the months of April through October when algal activity is increased.

The historical data were analyzed for trends in phosphorus, ammonia, nitrite plus nitrate, and orthophosphate. Seasonal Kendall trend tests showed a significant $(\rho<0.05)$ downward trend for phosphorus (unfiltered) in the Columbia River at Warrendale for the period 1973-94 (table 50, at back of report). Phosphorus concentrations decreased by 2.8 percent (nonflow adjusted) or 2.3 percent (flow adjusted) per year. This was the largest trend found in the lower Columbia River Basin. This trend may be a consequence of more conservative agricultural practices in the area upstream from Warrendale. A similar downward trend in phosphorus concentrations was observed in the Yakima River Basin, the most intensively irrigated basin in the United States, which drains to the Columbia River upstream from Warrendale (Rinella and others, 1992, p. 110). Because phosphorus is commonly associated with sediment particles (Hem, 1989), this downward trend also may have been influenced by the downward trend in suspended-sediment concentration. No significant trends for phosphorus were found in the Willamette River at Portland, the only other site with adequate data for trend testing. There were not adequate data to test for trends in ammonia, nitrite-plus-nitrate, and orthophosphate concentrations.

Adequate historical data were available for the Columbia River at Warrendale and the Willamette River at Portland to calculate monthly and annual mean daily loads for phosphorus in unfiltered water and ammonia and nitrite plus nitrate in filtered water for a period of about 20 years (1974-94). See the "Data-Analysis Methods" section for a discussion of the use of the ESTIMATOR program. The 1974, 1975, and 1977 water years represent conditions of high-, median-, and low-streamflow, respectively, and their estimated loads are shown in table 21. When the nutrient loads for the 1994 water year are compared with these historic loads, they are closest in magnitude to the low-flow water year of 1977 (table 21). This is consistent with the fact that 1994 was generally a year of lower precipitation and streamflow.

Load is a function of both concentration and streamflow. This relation explains how the annual mean daily loads for ammonia, nitrite plus nitrate, and phosphorus in 1994 at Warrendale could be larger by about twofold than those loads in the Willamette River (table 21), even though concentrations were higher in the Willamette River than at Warrendale (table 20). 
Table 21. Calculated monthly and annual mean daily nutrient loads for the current water year and low, median, and high streamflow water years in the Columbia River at Warrendale and Willamette River at Portland, lower Columbia River Basin, Oregon

[See table 7 for full site name; loads are reported in tons per day; all mean-daily loads were calculated using ESTIMATOR (Cohn and others, 1992); see the "Streamflow Conditions" section for a description of flow-year designations]

\begin{tabular}{|c|c|c|c|c|c|c|c|c|}
\hline \multirow{2}{*}{ Month } & \multicolumn{2}{|c|}{$\begin{array}{c}1977 \\
\text { Low streamflow year }\end{array}$} & \multicolumn{2}{|c|}{$\begin{array}{c}1975 \\
\text { Median streamflow year }\end{array}$} & \multicolumn{2}{|c|}{$\begin{array}{c}1974 \\
\text { High streamflow year }\end{array}$} & \multicolumn{2}{|c|}{$\begin{array}{c}1994 \\
\text { Current year }\end{array}$} \\
\hline & Warrendale & Willamette & Warrendale & Willamette & Warrendale & Willamette & Warrendale & Willamette \\
\hline \multicolumn{9}{|c|}{ Ammonia, filtered water } \\
\hline October & 24 & 3 & 21 & 4 & 14 & 3 & 12 & 4 \\
\hline November & 18 & 4 & 18 & 5 & 16 & 15 & 12 & 3 \\
\hline December & 15 & 3 & 16 & 12 & 25 & 20 & 10 & 7 \\
\hline January & 14 & 3 & 18 & 16 & 42 & 19 & 8 & 10 \\
\hline February & 8 & 3 & 17 & 12 & 28 & 14 & 10 & 7 \\
\hline March & 7 & 7 & 21 & 11 & 23 & 13 & 7 & 8 \\
\hline April & 5 & 4 & 20 & 6 & 40 & 10 & 10 & 6 \\
\hline May & 9 & 4 & 46 & 6 & 58 & 6 & 21 & 3 \\
\hline June & 10 & 3 & 62 & 3 & 130 & 5 & 23 & 3 \\
\hline July & 7 & 2 & 35 & 2 & 68 & 3 & 18 & 2 \\
\hline August & 10 & 2 & 19 & 2 & 29 & 2 & 9 & 2 \\
\hline September & 12 & 3 & 15 & 3 & 22 & 2 & 6 & 2 \\
\hline Annual & 12 & 3 & 26 & 7 & 41 & 9 & 12 & 5 \\
\hline \multicolumn{9}{|c|}{ Nitrite plus nitrate, filtered water } \\
\hline October & 60 & 14 & 54 & 15 & 41 & 14 & 37 & 14 \\
\hline November & 87 & 18 & 87 & 30 & 79 & 150 & 66 & 15 \\
\hline December & 130 & 13 & 130 & 120 & 180 & 240 & 95 & 49 \\
\hline January & 170 & 16 & 200 & 200 & 360 & 280 & 130 & 91 \\
\hline February & 130 & 15 & 210 & 140 & 300 & 170 & 150 & 70 \\
\hline March & 100 & 59 & 210 & 120 & 210 & 170 & 100 & 71 \\
\hline
\end{tabular}


Table 21. Calculated monthly and annual mean daily nutrient loads for the current water year and low, median, and high streamflow water years in the Columbia River at Warrendale and Willamette River at Portland, lower Columbia River Basin, Oregon-Continued

[See table 7 for full site name; loads are reported in tons per day; all mean-daily loads were calculated using ESTIMATOR (Cohn and others, 1992); see the "Streamflow Conditions" section for a description of flow-year designations]

\begin{tabular}{|c|c|c|c|c|c|c|c|c|}
\hline \multirow{2}{*}{ Month } & \multicolumn{2}{|c|}{$\begin{array}{c}1977 \\
\text { Low streamflow year }\end{array}$} & \multicolumn{2}{|c|}{$\begin{array}{c}1975 \\
\text { Median streamflow year }\end{array}$} & \multicolumn{2}{|c|}{$\begin{array}{c}1974 \\
\text { High streamflow year }\end{array}$} & \multicolumn{2}{|c|}{$\begin{array}{c}1994 \\
\text { Current year }\end{array}$} \\
\hline & Warrendale & Willamette & Warrendale & Willamette & Warrendale & Willamette & Warrendale & Willamette \\
\hline \multicolumn{9}{|c|}{ Nitrite plus nitrate, filtered water-Continued } \\
\hline April & 53 & 28 & 130 & 47 & 200 & 110 & 81 & 46 \\
\hline May & 46 & 29 & 130 & 44 & 160 & 40 & 79 & 15 \\
\hline June & 29 & 13 & 96 & 18 & 150 & 31 & 49 & 12 \\
\hline July & 15 & 6 & 44 & 9 & 70 & 10 & 29 & 6 \\
\hline August & 17 & 6 & 27 & 7 & 36 & 6 & 16 & 6 \\
\hline September & 25 & 10 & 28 & 11 & 36 & 8 & 16 & 7 \\
\hline Annual & 72 & 19 & 110 & 63 & 150 & 100 & 70 & 33 \\
\hline \multicolumn{9}{|c|}{ Phosphorus, unfiltered water } \\
\hline October & 17 & 4 & 15 & 4 & 10 & 4 & 9 & 4 \\
\hline November & 16 & 4 & 16 & 6 & 14 & 23 & 12 & 3 \\
\hline December & 18 & 2 & 19 & 15 & 29 & 28 & 12 & 7 \\
\hline January & 21 & 2 & 26 & 19 & 57 & 25 & 14 & 10 \\
\hline February & 15 & 2 & 28 & 12 & 44 & 15 & 17 & 7 \\
\hline March & 13 & 6 & 35 & 11 & 37 & 15 & 14 & 7 \\
\hline April & 9 & 4 & 29 & 6 & 53 & 11 & 16 & 5 \\
\hline May & 13 & 4 & 49 & 6 & 62 & 6 & 25 & 3 \\
\hline June & 11 & 3 & 51 & 4 & 94 & 6 & 21 & 3 \\
\hline July & 6 & 2 & 24 & 2 & 45 & 3 & 14 & 2 \\
\hline August & 7 & 2 & 12 & 2 & 18 & 2 & 6 & 2 \\
\hline September & 8 & 3 & 10 & 4 & 14 & 2 & 5 & 2 \\
\hline Annual & 13 & 3 & 26 & 8 & 40 & 12 & 14 & 4 \\
\hline
\end{tabular}


Nutrient loads also had seasonal patterns. Phosphorus and ammonia had the same pattern of higher loads during periods of higher streamflow. This period corresponds to May through July for the Columbia River at Warrendale and November through March for the Willamette River (fig. 8). Since phosphorus is commonly associated with sediment particles (Hem, 1989) and higher suspended-sediment concentrations and loads correspond to seasonally higher streamflows (table 18), it is expected that phosphorus loads would be larger when flows are higher. Because of the relation between load and streamflow, ammonia loads also would be expected to increase during periods of higher runoff. In contrast to ammonia and phosphorus, nitrite-plus-nitrate loads are influenced more by season than by streamflow. Both the Warrendale and the Willamette sites had their highest loads during the winter months of December through March. During these periods of colder temperatures and less light, nitrogen uptake by algae is decreased, and, therefore, the nitrogen concentration in the river is increased.

Seasonal patterns for ammonia and phosphorus loads at Warrendale differed among low, median, and high streamflow years (table 21). In 1977, for example, the typically higher streamflows in the Columbia River from May through July were absent (fig. 5); consequently, June phosphorus loads in 1977 were nearly nine times smaller than in June 1974-a high streamflow year. Similar patterns and magnitude differences existed for ammonia loads among streamflow years.

Loads were also calculated (using the ESTIMATOR program) for the same three nutrient constituents at the Columbia River at Beaver Army Terminal for 1994, using data from 1990-94 to calculate the regression equation. Table 22 shows these load estimates for the calendar year 1994 at all three sites for comparison. Because the Willamette River is the major source of nutrients to the Columbia River main stem between the Warrendale and Beaver sites, from a simple mass balance standpoint, loads at the Beaver site would be expected to be approximately equal to the sum of the loads at the Warrendale and Willamette sites during the entire year. However, that was the case only for phosphorus (fig. 27); load sums for ammonia and nitrite plus nitrate differed from the load at Beaver during much of 1994. The explanation for the differences is tied to algal growth cycles.

The loads for ammonia generally fit the additive model from November through April. From May through October, however, the load at Beaver was much lower than expected from the sum. For example, in June, the load at Beaver (12 tons/day) was less than half of the sum of the loads at Warrendale and Willamette (26 tons/day). This time period corresponds to the growth period in the algae life cycle when nitrogen uptake is at its maximum. Consequently, some of the ammonia, the preferred nitrogen species for algae, probably is consumed by the algae before it reaches Beaver Army Terminal. The relation between the algae and ammonia can be seen in the ratio of the chlorophyll $a$ concentration in milligrams per liter (an indirect measure of algal productivity) to the ammonia concentration in millgrams per liter. The ratio increased tenfold from February 17 (54) to June 10 (560), supporting the concept that increased algal activity in the summer results in decreased ammonia concentrations.

The algae have a similar effect on the nitriteplus-nitrate loads from June through September at all three sites, but, in general, the additive model holds. From October to May, however, the load at Beaver is much higher than predicted by the sum of the Warrendale and Willamette loads. This pattern suggests that the input from the Willamette River does not fully account for the increase, and inputs from the other tributaries and point and nonpoint sources have a significant effect during this time period. Possible sources of nitrite plus nitrate include the 39 domestic facilities (most of which are sewage-treatment plants) that ultimately discharge into the Columbia River (fig. 10).

For all three constituents, the load at Beaver for December was much higher than for the rest of the year. This is especially apparent for the nitriteplus-nitrate load, which had a mean daily value of 730 tons/day for December and a second-highest value of only 370 tons/day for February. These elevated December loads at Beaver were due to the increased streamflow at Beaver, not increased concentrations. For example, the nitrite-plus-nitrate concentration rose from $0.35 \mathrm{mg} / \mathrm{L}$ on November 10 at Beaver to only $0.37 \mathrm{mg} / \mathrm{L}$ on December 8 , but the streamflow nearly doubled from $150,000 \mathrm{ft}^{3} / \mathrm{s}$ on October 27 to $296,000 \mathrm{ft}^{3} / \mathrm{s}$ on December 8 . In contrast, the streamflow at Warrendale was kept 
Table 22. Calculated monthly and annual mean daily loads for ammonia and nitrite plus nitrate in filtered water and phosphorus in unfiltered water at selected sites, lower Columbia River Basin, Oregon, 1994

[The term "filtered water" is an operational definition referring to the chemical analysis of that portion of a water-suspended sediment sample that passes through a nominal 0.45-micrometer filter; conversely, the term "unfiltered water" refers to the chemical analysis of a water sample that has not been filtered or centrifuged, nor in any way altered from the original matrix; loads are reported in tons per day; see table 7 for full site names; all mean daily loads calculated using ESTIMATOR (Cohn and others, 1992a)]

\begin{tabular}{|c|c|c|c|c|c|c|c|c|c|c|c|c|}
\hline \multirow{2}{*}{ Month } & \multicolumn{4}{|c|}{ Ammonia, filtered water } & \multicolumn{4}{|c|}{ Nitrite plus nitrate, filtered water } & \multicolumn{4}{|c|}{ Phosphorus, unfiltered water } \\
\hline & Warrendale & Willamette & Beaver & $\begin{array}{l}\text { Warrendale }+ \\
\text { Willamette }\end{array}$ & Warrendale & Willamette & Beaver & $\begin{array}{l}\text { Warrendale }+ \\
\text { Willamette }\end{array}$ & Warrendale & Willamette & Beaver & $\begin{array}{l}\text { Warrendale + } \\
\text { Willamette }\end{array}$ \\
\hline January & 8 & 10 & 17 & 18 & 130 & 91 & 380 & 221 & 14 & 10 & 19 & 24 \\
\hline February & 10 & 7 & 17 & 17 & 150 & 70 & 370 & 220 & 17 & 7 & 20 & 24 \\
\hline March & 7 & 8 & 14 & 15 & 100 & 71 & 240 & 171 & 14 & 7 & 18 & 21 \\
\hline April & 10 & 6 & 13 & 16 & 81 & 46 & 140 & 127 & 16 & 5 & 17 & 21 \\
\hline May & 21 & 3 & 15 & 24 & 79 & 15 & 110 & 94 & 25 & 3 & 23 & 28 \\
\hline June & 23 & 3 & 12 & 26 & 49 & 12 & 59 & 61 & 21 & 3 & 21 & 24 \\
\hline July & 18 & 2 & 8 & 20 & 29 & 6 & 30 & 35 & 14 & 2 & 16 & 16 \\
\hline August & 9 & 2 & 5 & 11 & 16 & 6 & 16 & 22 & 6 & 2 & 9 & 8 \\
\hline September & 6 & 2 & 4 & 8 & 16 & 7 & 18 & 23 & 5 & 2 & 8 & 7 \\
\hline October & 10 & 3 & 8 & 13 & 34 & 14 & 58 & 48 & 8 & 4 & 12 & 12 \\
\hline November & 12 & 9 & 19 & 21 & 66 & 64 & 250 & 130 & 11 & 11 & 26 & 22 \\
\hline December & 13 & 14 & 35 & 27 & 120 & 140 & 730 & 260 & 16 & 17 & 41 & 33 \\
\hline Annual & 12 & 6 & 14 & 18 & 71 & 45 & 200 & 116 & 14 & 6 & 19 & 20 \\
\hline
\end{tabular}



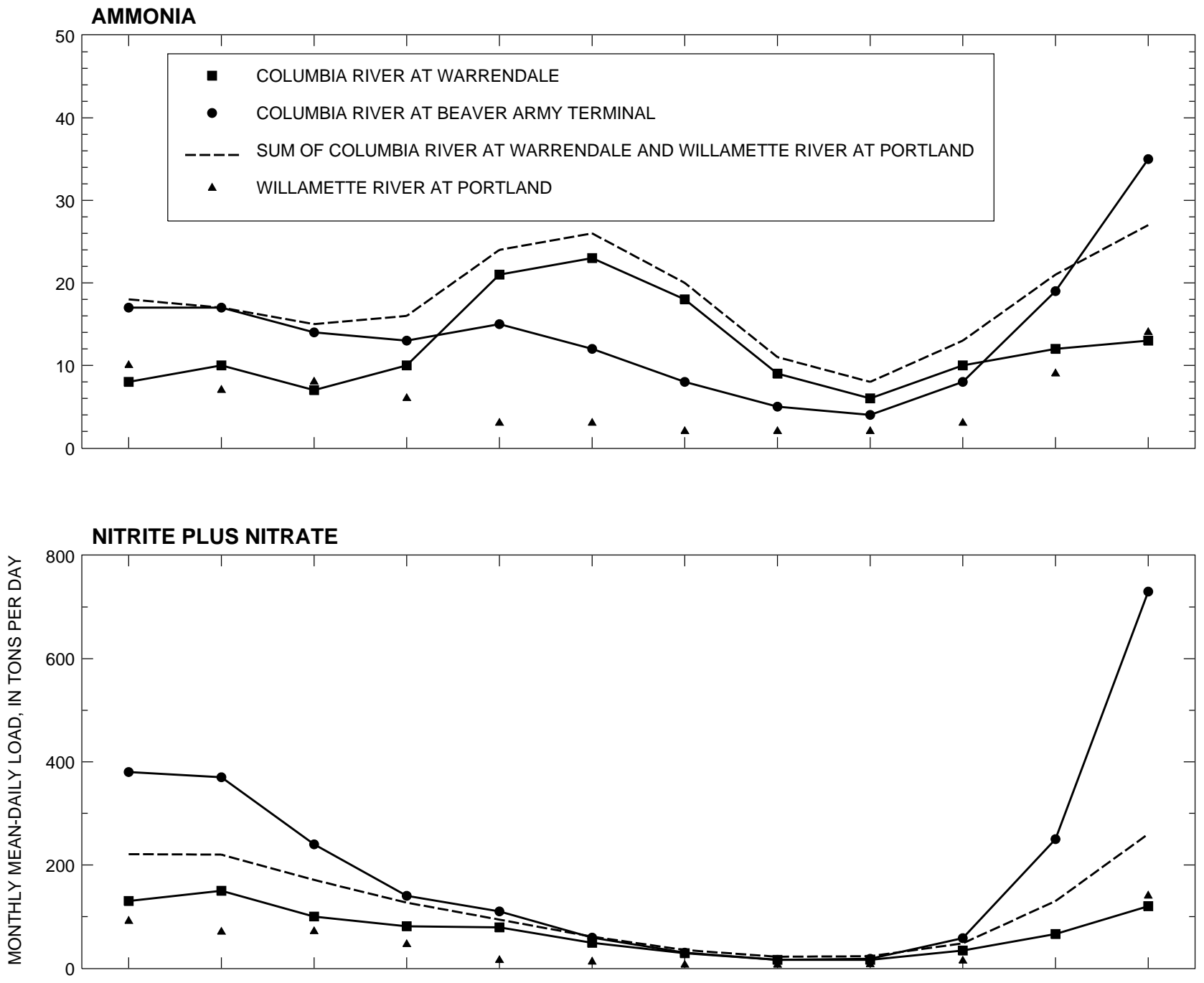

PHOSPHORUS

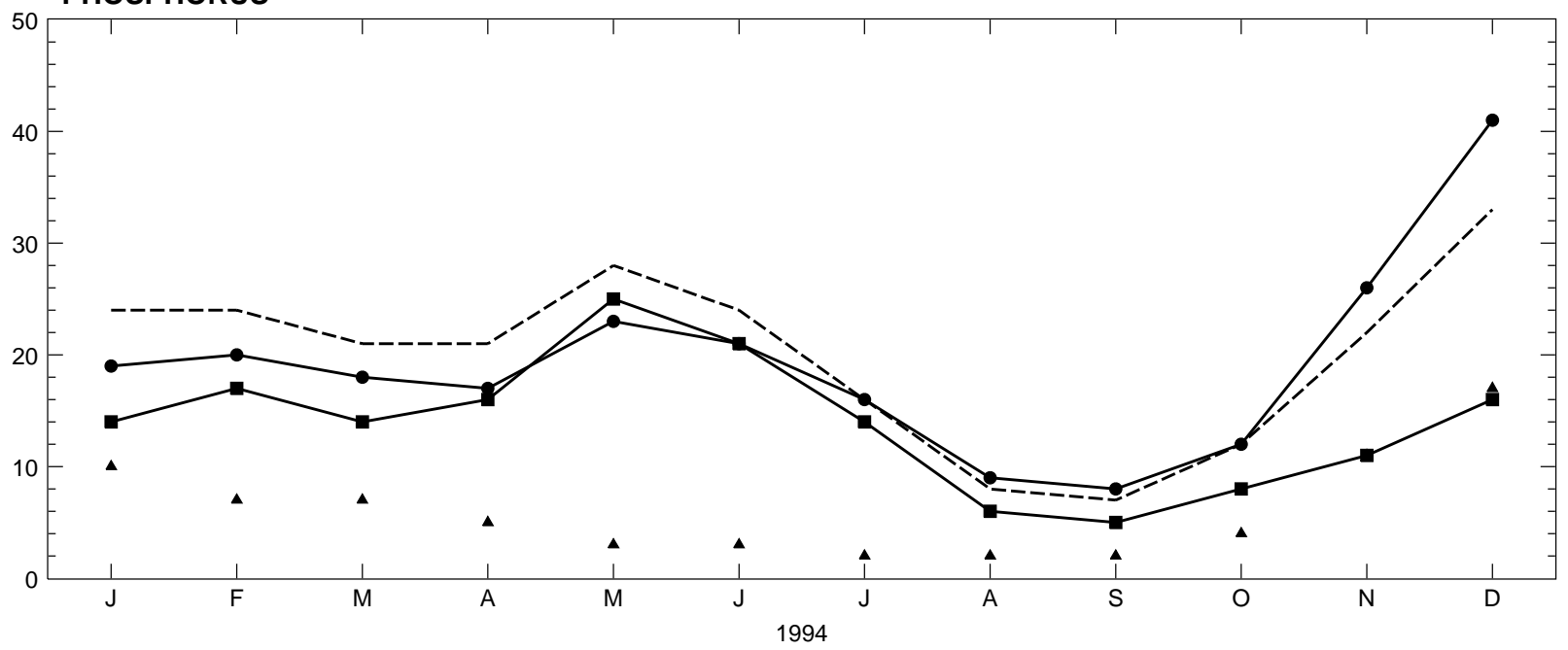

Figure 27. Monthly mean daily loads of ammonia and nitrite plus nitrate in filtered water and phosphorus in unfiltered water in th Columbia River at Warrendale, Willamette River at Portland, and Columbia River at Beaver Army Terminal, lower Columbia Rive Basin, Oregon and Washington, 1994. 
within the range of about $90,000 \mathrm{ft}^{3} / \mathrm{s}$ to 140,000 $\mathrm{ft}^{3} / \mathrm{s}$ by the operation of Bonneville Dam (fig. 8).

The transport dynamics of these three nutrients were studied by computing the instantaneous loads over three reaches of the main stem. The loads were calculated for both July and September of 1994. For each reach, the measured load at the downstream site (site-measured load) was compared with the calculated load for the reach (reach-calculated load), and the difference between the two was computed (tables 23 and 24). This type of analysis is called mass balance. The smaller the difference between the site-measured load and the reachcalculated load, the better the mass balance is for the reach. For comparison, mass-balance calculations also were made for streamflow, a conservative measure, and suspended sediment, a measure related to phosphorus loads. A positive difference between measured and calculated nutrient loads (calculated load greater than measured load) implies that unmeasured contributions to the site-measured load exist (from point sources, nonpoint sources, or resuspension and transport of streambed sediment); whereas a negative difference implies that unmeasured losses exist in the reach (from biological processes or suspended-sediment deposition). It should be noted that samples used in making intersite-load comparisons in this study were separated by days or weeks. Consequently, variability in daily mean streamflow and daily concentrations can contribute to differences that were observed between sitemeasured and reach-calculated loads.

In general, the mass balance for ammonia and nitrite-plus-nitrate loads was better in September than in July (table 23). Streamflow in the Columbia River was less variable during the September period than in July, when the streamflow was still decreasing (fig. 8). Another possible explanation for differences in mass balance between July and September is the effect of algal productivity. For example, chlorophyll $a$ concentrations at Beaver decreased from $6.5 \mu \mathrm{g} / \mathrm{L}$ on July 28 to only $3.3 \mu \mathrm{g} / \mathrm{L}$ on September 12. This decrease indicates that algal productivity in July probably accounts for decreases in ammonia and nitrate loads. This removal by the algae may explain the losses in load reported at Beaver of 4.6 tons/day of ammonia and 20 tons/day of nitrite plus nitrate.
When examining the loads for phosphorus in unfiltered water, it is important also to examine the loads for suspended sediment (table 24). In July, the difference between site-measured and reachcalculated loads for suspended sediment and phosphorus can best be described by the effects of streamflow. For example, in the reach from Hayden Island (RM 102) to Columbia City (RM 84), the unaccounted-for gains in both phosphorus and suspended-sediment loads may be explained by the increased streamflow and resuspension of suspended sediment. In September, phosphorus loads, suspended-sediment loads, and streamflow were all smaller than they were in July. In table 24 , there is very good balance for both phosphorus and suspended-sediment loads for the reach from Hayden Island to Columbia City, indicating little or no net deposition or resuspension. From Columbia City to Beaver (RM 53.8), however, there are unaccounted-for losses in both phosphorus and suspended sediment, indicating that deposition is occurring. This situation was expected due to the large input of suspended-sediment from the Cowlitz River and the low streamflow in the Columbia River main stem. The suspended-sediment load from the Cowlitz River (270 tons/day) represents 22 percent of the load measured at Beaver (1,200 tons/day).

\section{Major Ions and Related Measures}

Sources of major ions in water include mineral and organic assemblages in rocks and soils that contact surface and ground water and undergo natural weathering (solubilizing processes). Additional sources include point discharges (for example, effluents from sewage-treatment plants) and nonpoint discharges (for example, agricultural and urban runoff). Major cations include calcium $(\mathrm{Ca})$, magnesium $(\mathrm{Mg})$, sodium $(\mathrm{Na})$, and potassium $(\mathrm{K})$; major anions include bicarbonate $\left(\mathrm{HCO}_{3}\right)$, sulfate $\left(\mathrm{SO}_{4}\right)$, chloride $(\mathrm{Cl})$, fluoride $(\mathrm{F})$, and nitrate $\left(\mathrm{NO}_{3}\right)$, and uncharged species such as silica $\left[\mathrm{Si}(\mathrm{OH})_{4}\right]$. Collectively, the total concentration of dissolved material in water (inorganic salts and organic matter) is referred to as total dissolved solids (TDS) or "filterable residue".

Median concentrations of $\mathrm{Ca}, \mathrm{Mg}, \mathrm{Na}, \mathrm{K}, \mathrm{Cl}$, $\mathrm{SO}_{4}$, and TDS (14, 4.0, 6.3, 1.1, 4.1, 9.6 and 78 $\mathrm{mg} / \mathrm{L}$, respectively) in the lower Columbia River Basin in 1994 (table 25) were similar to mean 
Table 23. Mass balances for streamflow and ammonia and nitrite-plus-nitrate loads in filtered water, lower Columbia River Basin, Oregon and Washington, 1994 [Loads were determined from instantaneous measurements of ammonia and nitrite-plus-nitrate concentrations in filtered water and phosphorus concentrations in unfiltered water; the tern "filtered water" is an operational definition referring to the chemical analysis of that portion of a water-suspended sediment sample that passes through a nominal 0.45 -micrometer filter; conversely, the term "unfiltered water" refers to the chemical analysis of a water sample that has not been filtered or centrifuged, nor in any way altered from the original matrix; $\mathrm{ft}^{3} / \mathrm{s}$, cubic feet per second; --, not applicable; cd, data is censored (below method reporting limit); see table 7 for full site names; see page 73 for a discussion of the mass-balance approach]

\begin{tabular}{|c|c|c|c|c|c|c|c|c|c|c|c|c|c|c|}
\hline \multirow[b]{3}{*}{ Site name } & \multirow[b]{3}{*}{$\begin{array}{l}\text { Sampling } \\
\text { date }\end{array}$} & \multirow[b]{3}{*}{$\begin{array}{c}\text { Columbia } \\
\text { river } \\
\text { mile }\end{array}$} & \multicolumn{4}{|c|}{ Streamflow $\left(\mathrm{ft}^{3} / \mathbf{s}\right)$} & \multicolumn{4}{|c|}{ Ammonia load (tons/day) } & \multicolumn{4}{|c|}{ Nitrite-plus-nitrate load (tons/day) } \\
\hline & & & \multicolumn{3}{|c|}{ Main Stem } & \multirow[b]{2}{*}{ 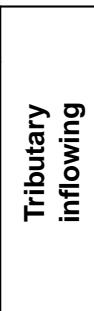 } & \multicolumn{3}{|c|}{ Main stem } & \multirow[b]{2}{*}{ 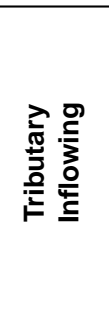 } & \multicolumn{3}{|c|}{ Main stem } & \multirow[b]{2}{*}{ 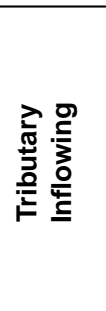 } \\
\hline & & & 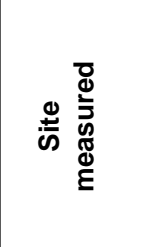 & 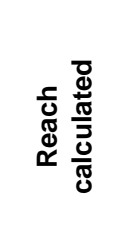 & 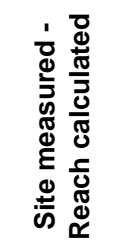 & & 畩 & 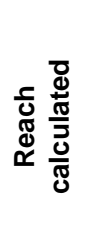 & 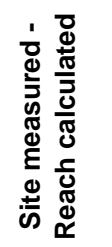 & & 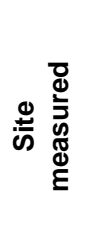 & 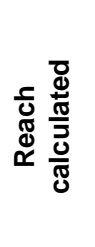 & 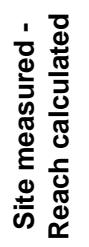 & \\
\hline \multicolumn{15}{|c|}{ July 1994} \\
\hline Warrendale & $07-27-1994$ & 141 & 144,000 & -- & -- & -- & 12 & -- & -- & -- & 25 & -- & -- & -- \\
\hline Sandy River & 07-07-1994 & 120.5 & -- & -- & -- & 725 & -- & -- & -- & 0.020 & -- & -- & -- & $\mathrm{cd}$ \\
\hline Hayden Island & 07-25-1994 & 102 & 142,000 & 144,725 & $-2,725$ & -- & 15 & 12 & +3 & -- & 19 & 25 & -6 & -- \\
\hline Willamette River & 07-25-1994 & 101.5 & -- & -- & -- & 9,000 & -- & -- & -- & 1.4 & -- & -- & -- & 7.0 \\
\hline Lewis River & 07-19-1994 & 87 & -- & -- & -- & 1,260 & -- & -- & -- & .068 & -- & -- & -- & $\mathrm{cd}$ \\
\hline Columbia City & 07-26-1994 & 84 & 160,000 & 152,260 & $+7,740$ & -- & 13 & 16 & -3 & -- & 65 & 26 & +39 & -- \\
\hline Kalama River & 07-13-1994 & 73.1 & -- & -- & -- & 260 & -- & -- & -- & .014 & -- & -- & -- & .039 \\
\hline Cowlitz River & 07-14-1994 & 68 & -- & -- & -- & 4,390 & -- & -- & -- & $\mathrm{cd}$ & -- & -- & -- & 1.0 \\
\hline Beaver Army Terminal & 07-28-1994 & 53.8 & 155,000 & 164,650 & $-9,650$ & -- & 8.4 & 13 & -4.6 & -- & 46 & 66 & -20 & -- \\
\hline \multicolumn{15}{|c|}{ September 1994} \\
\hline Warrendale & $09-15-1994$ & 141 & 72,500 & -- & -- & -- & 3.9 & -- & -- & -- & $\mathrm{cd}$ & -- & -- & -- \\
\hline Sandy River & 09-19-1994 & 120.5 & -- & -- & -- & 299 & -- & -- & -- & .016 & -- & -- & -- & $\mathrm{cd}$ \\
\hline Hayden Island & 09-13-1994 & 102 & 73,700 & 72,799 & +901 & -- & 4.0 & 3.9 & +.1 & -- & 10 & $\mathrm{~cd}$ & -- & -- \\
\hline Willamette River & 09-13-1994 & 101.5 & -- & -- & -- & 9,100 & -- & -- & -- & 2.2 & -- & -- & -- & 5.9 \\
\hline Lewis River & 09-07-1994 & 87 & -- & -- & -- & 1,250 & -- & -- & -- & .034 & -- & -- & -- & $\mathrm{cd}$ \\
\hline Columbia City & 09-14-1994 & 84 & 97,200 & 84,050 & $+13,150$ & -- & 5.2 & 6.2 & -1 & -- & 17 & 16 & +1 & -- \\
\hline Kalama River & 09-06-1994 & 73.1 & -- & -- & -- & 189 & -- & -- & -- & .0051 & -- & -- & -- & .039 \\
\hline Cowlitz River & 08-31-1994 & 68 & -- & -- & -- & 3,230 & -- & -- & -- & $\mathrm{cd}$ & -- & -- & -- & 1.3 \\
\hline Beaver Army Terminal & 09-12-1994 & 53.8 & 93,000 & 100,619 & $-7,619$ & -- & 5.0 & 5.2 & -.2 & -- & 22 & 18 & +4 & -- \\
\hline
\end{tabular}


Table 24. Mass balances for streamflow, phosphorus loads in unfiltered water, and suspended-sediment loads, lower Columbia River Basin, Oregon and Washington, 1994

[Loads were determined from instantaneous measurements of ammonia and nitrite-plus-nitrate concentrations in filtered water and phosphorus concentrations in unfiltered water; the tern "filtered water" is an operational definition referring to the chemical analysis of that portion of a water-suspended sediment sample that passes through a nominal 0.45 -micrometer filter; conversely, the term "unfiltered water" refers to the chemical analysis of a water sample that has not been filtered or centrifuged, nor in any way altered from the original matrix; $\mathrm{ft}^{3} / \mathrm{s}$, cubic feet per second; --, not applicable; cd, data is censored (below method reporting limit); see table 7 for full site names; see page 73 for a discussion of the mass-balance approach]

\begin{tabular}{|c|c|c|c|c|c|c|c|c|c|c|c|c|c|c|}
\hline \multirow[b]{3}{*}{ Site name } & \multirow[b]{3}{*}{$\begin{array}{l}\text { Sampling } \\
\text { date }\end{array}$} & \multirow[b]{3}{*}{$\begin{array}{l}\text { Columbia } \\
\text { river } \\
\text { mile }\end{array}$} & \multicolumn{4}{|c|}{ Streamflow $\left(\mathrm{ft}^{3} / \mathrm{s}\right)$} & \multicolumn{4}{|c|}{ Phosphorus load (tons/day) } & \multicolumn{4}{|c|}{$\begin{array}{l}\text { Suspended-sediment load } \\
\text { (tons/day) }\end{array}$} \\
\hline & & & \multicolumn{3}{|c|}{ Main Stem } & \multirow[b]{2}{*}{ 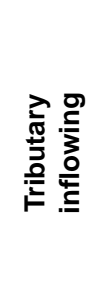 } & \multicolumn{3}{|c|}{ Main stem } & \multirow[b]{2}{*}{ 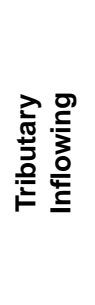 } & \multicolumn{3}{|c|}{ Main stem } & \multirow[b]{2}{*}{ 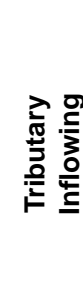 } \\
\hline & & & 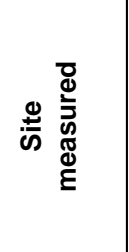 & 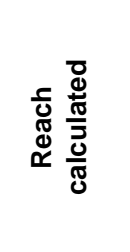 & 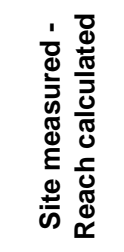 & & 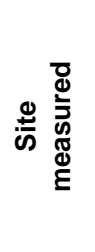 & 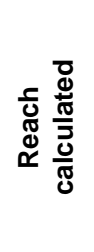 & 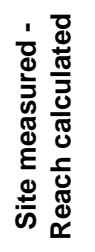 & & क & 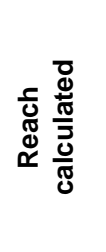 & 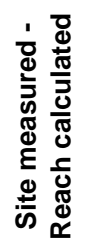 & \\
\hline \multicolumn{15}{|c|}{ July 1994} \\
\hline Warrendale & $07-27-1994$ & 141 & 144,000 & -- & -- & -- & 7.8 & -- & -- & -- & 2,300 & -- & -- & -- \\
\hline Sandy River & 07-07-1994 & 120.5 & -- & -- & -- & 725 & -- & -- & -- & $\mathrm{cd}$ & -- & -- & -- & 5.9 \\
\hline Hayden Island & 07-25-1994 & 102 & 142,000 & 144,725 & $-2,725$ & -- & 12 & 7.8 & +4.2 & -- & 2,700 & 2,300 & +400 & -- \\
\hline Willamette River & 07-25-1994 & 101.5 & -- & -- & -- & 9,000 & -- & -- & -- & 2.7 & -- & -- & -- & 290 \\
\hline Lewis River & 07-19-1994 & 87 & -- & -- & -- & 1,260 & -- & -- & -- & 0.068 & -- & -- & -- & 10 \\
\hline Columbia City & 07-26-1994 & 84 & 160,000 & 152,260 & $+7,740$ & -- & 17 & 15 & +2 & -- & 3,900 & 3,000 & +900 & -- \\
\hline Kalama River & 07-13-1994 & 73.1 & -- & -- & -- & 260 & -- & -- & -- & .021 & -- & -- & -- & 3.5 \\
\hline Cowlitz River & 07-14-1994 & 68 & -- & -- & -- & 4,390 & -- & -- & -- & .12 & -- & -- & -- & 130 \\
\hline Beaver Army Terminal & 07-28-1994 & 53.8 & 155,000 & 164,650 & $-9,650$ & -- & 25 & 17 & +8 & -- & 3,300 & 4,000 & -700 & -- \\
\hline \multicolumn{15}{|c|}{ September 1994} \\
\hline Warrendale & 09-15-1994 & 141 & 72,500 & -- & -- & -- & 3.9 & -- & -- & -- & 780 & -- & -- & -- \\
\hline Sandy River & 09-19-1994 & 120.5 & -- & -- & -- & 299 & -- & -- & -- & $\mathrm{cd}$ & -- & -- & -- & 2.4 \\
\hline Hayden Island & 09-13-1994 & 102 & 73,700 & 72,799 & +901 & -- & 6.0 & 3.9 & +2.1 & -- & 1,200 & 780 & +420 & -- \\
\hline Willamette River & 09-13-1994 & 101.5 & -- & -- & -- & 9,100 & -- & -- & -- & 1.7 & -- & -- & -- & 120 \\
\hline Lewis River & 09-07-1994 & 87 & -- & -- & -- & 1,250 & -- & -- & -- & $\mathrm{cd}$ & -- & -- & -- & 3.4 \\
\hline Columbia City & 09-14-1994 & 84 & 97,200 & 84,050 & $+13,150$ & -- & 7.9 & 7.7 & +.2 & -- & 1,300 & 1,300 & 0 & -- \\
\hline Kalama River & 09-06-1994 & 73.1 & -- & -- & -- & 189 & -- & -- & -- & .0051 & -- & -- & -- & 1.0 \\
\hline Cowlitz River & 08-31-1994 & 68 & -- & -- & -- & 3,230 & -- & -- & -- & $\mathrm{cd}$ & -- & -- & -- & 270 \\
\hline Beaver Army Terminal & 09-12-1994 & 53.8 & 93,000 & 100,619 & $-7,619$ & -- & 5.0 & 7.9 & -2.9 & -- & 1,200 & 1,600 & -400 & -- \\
\hline
\end{tabular}


Table 25. Distribution of major-ion concentrations in filtered and unfiltered water, lower Columbia River Basin, Oregon and Washington, 1994

[All measurements were performed on filtered-water samples, except specific conductance which was determined from an unfiltered-water sample; the term "filtered water" is an operational definition referring to the chemical analysis of that portion of a water-suspended sediment sample that passes through a nominal 0.45-micrometer filter; conversely, the term "unfiltered water" refers to the chemical analysis of a water sample that has not been filtered or centrifuged, nor in any way altered from the original matrix; to avoid statistical bias that may be associated with constituents analyzed more than once at a site, only one element concentration per month was statistically summarized; values are reported in milligrams per liter, except where shown to be otherwise; see table 7 for full site names; -- indicates fewer than 6 samples collected, therefore the percentile was not calculated; <, less than]

\begin{tabular}{|c|c|c|c|c|c|c|c|c|}
\hline \multirow{2}{*}{ Site name } & \multirow{2}{*}{$\begin{array}{c}\text { Number } \\
\text { of } \\
\text { samples }\end{array}$} & \multirow{2}{*}{$\begin{array}{l}\text { Minimum } \\
\text { value }\end{array}$} & \multicolumn{5}{|c|}{ Value at indicated percentile } & \multirow{2}{*}{$\begin{array}{l}\text { Maximum } \\
\text { value }\end{array}$} \\
\hline & & & 10 & 25 & 50 & 75 & 90 & \\
\hline \multicolumn{9}{|c|}{ Alkalinity } \\
\hline Warrendale & 11 & 52.0 & 52.2 & 55.0 & 62.0 & 69.0 & 75.8 & 77.0 \\
\hline Hayden Island & 12 & 53.0 & 53.3 & 55.2 & 59.0 & 66.0 & 71.0 & 71.0 \\
\hline Columbia City & 12 & 48.0 & 48.3 & 51.2 & 54.5 & 61.5 & 66.4 & 67.0 \\
\hline Beaver & 11 & 44.0 & 45.0 & 51.0 & 53.0 & 59.0 & 69.4 & 71.0 \\
\hline Willamette River & 14 & 15.0 & 16.5 & 21.8 & 25.0 & 27.0 & 28.0 & 29.0 \\
\hline Multnomah Channel & 11 & 23.0 & 23.2 & 31.0 & 36.0 & 46.0 & 48.6 & 49.0 \\
\hline Sandy River & 11 & 12.0 & 12.0 & 13.0 & 15.0 & 22.0 & 24.4 & 25.0 \\
\hline Lewis River & 4 & 16.0 & -- & -- & 17.0 & -- & -- & 20.0 \\
\hline Kalama River & 4 & 20.0 & -- & -- & 23.5 & -- & -- & 24.0 \\
\hline Cowlitz River & 4 & 25.0 & -- & -- & 26.5 & -- & -- & 27.0 \\
\hline All Sites & 94 & 12.0 & 16.5 & 24.0 & 46.5 & 56.2 & 66.0 & 77.0 \\
\hline \multicolumn{9}{|c|}{ Calcium } \\
\hline Warrendale & 11 & 16.0 & 16.0 & 16.0 & 17.0 & 20.0 & 21.0 & 21.0 \\
\hline Hayden Island & 12 & 15.0 & 15.3 & 16.0 & 17.0 & 19.3 & 20.7 & 21.0 \\
\hline Columbia City & 12 & 14.0 & 14.0 & 14.3 & 15.5 & 17.8 & 20.7 & 21.0 \\
\hline Beaver & 11 & 13.0 & 13.0 & 14.0 & 15.0 & 17.0 & 18.0 & 18.0 \\
\hline Willamette River & 14 & 5.0 & 5.1 & 6.1 & 6.9 & 7.4 & 7.9 & 8.2 \\
\hline Multnomah Channel & 11 & 5.4 & 5.6 & 6.8 & 9.7 & 13.0 & 14.8 & 15.0 \\
\hline Sandy River & 1 & 6.0 & -- & -- & 6.0 & -- & -- & 6.0 \\
\hline Lewis River & 4 & 4.0 & -- & -- & 4.2 & -- & -- & 4.3 \\
\hline Kalama River & 4 & 4.6 & -- & -- & 5.7 & -- & -- & 6.2 \\
\hline Cowlitz River & 4 & 7.7 & -- & -- & 8.9 & -- & -- & 9.3 \\
\hline All Sites & 84 & 4.0 & 5.4 & 7.3 & 14.0 & 17.0 & 19.0 & 21.0 \\
\hline \multicolumn{9}{|c|}{ Chloride } \\
\hline Warrendale & 11 & 2.0 & 2.0 & 2.1 & 3.0 & 3.8 & 4.0 & 4.0 \\
\hline Hayden Island & 12 & 1.9 & 2.0 & 2.7 & 3.5 & 4.3 & 5.0 & 5.0 \\
\hline Columbia City & 12 & 2.8 & 2.9 & 3.9 & 4.2 & 4.5 & 4.6 & 4.6 \\
\hline Beaver & 11 & 3.1 & 3.3 & 4.7 & 5.0 & 5.6 & 6.1 & 6.2 \\
\hline Willamette River & 12 & 3.2 & 3.3 & 3.7 & 4.3 & 5.8 & 6.3 & 6.3 \\
\hline Multnomah Channel & 11 & 4.3 & 4.4 & 4.9 & 6.4 & 9.1 & 13.1 & 14.0 \\
\hline Sandy River & 4 & 1.6 & -- & -- & 2.0 & -- & -- & 2.5 \\
\hline Lewis River & 4 & 1.6 & -- & -- & 1.8 & -- & -- & 1.9 \\
\hline Kalama River & 4 & 2.5 & -- & -- & 3.7 & -- & -- & 4.9 \\
\hline
\end{tabular}


Table 25. Distribution of major-ion concentrations in filtered and unfiltered water, lower Columbia River Basin, Oregon and Washington, 1994-Continued

[All measurements were performed on filtered-water samples, except specific conductance which was determined from an unfiltered-water sample; the term "filtered water" is an operational definition referring to the chemical analysis of that portion of a water-suspended sediment sample that passes through a nominal 0.45 -micrometer filter; conversely, the term "unfiltered water" refers to the chemical analysis of a water sample that has not been filtered or centrifuged, nor in any way altered from the original matrix; to avoid statistical bias that may be associated with constituents analyzed more than once at a site, only one element concentration per month was statistically summarized; values are reported in milligrams per liter, except where shown to be otherwise; see table 7 for full site names; -- indicates fewer than 6 samples collected, therefore the percentile was not calculated; <, less than]

\begin{tabular}{|c|c|c|c|c|c|c|c|c|}
\hline \multirow{2}{*}{ Site name } & \multirow{2}{*}{$\begin{array}{c}\text { Number } \\
\text { of } \\
\text { samples }\end{array}$} & \multirow{2}{*}{$\begin{array}{l}\text { Minimum } \\
\text { value }\end{array}$} & \multicolumn{5}{|c|}{ Value at indicated percentile } & \multirow{2}{*}{$\begin{array}{l}\text { Maximum } \\
\text { value }\end{array}$} \\
\hline & & & 10 & 25 & 50 & 75 & 90 & \\
\hline \multicolumn{9}{|c|}{ Chloride } \\
\hline Cowlitz River & 4 & 4.1 & -- & -- & 5.5 & -- & -- & 5.9 \\
\hline All Sites & $\overline{85}$ & 1.6 & 2.1 & 3.0 & 4.1 & 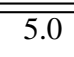 & 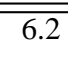 & 14.0 \\
\hline \multicolumn{9}{|c|}{ Fluoride } \\
\hline Warrendale & 11 & .1 & .1 & .1 & .1 & .2 & .2 & .2 \\
\hline Hayden Island & 12 & .1 & .1 & .1 & .1 & .2 & .2 & .2 \\
\hline Columbia City & 12 & $<.1$ & $<.1$ & .1 & .1 & .2 & .2 & .2 \\
\hline Beaver & 11 & $<.1$ & $<.1$ & .1 & .1 & .2 & .2 & .2 \\
\hline Willamette River & 12 & $<.1$ & $<.1$ & $<.1$ & $<.1$ & $<.1$ & $<.1$ & $<.1$ \\
\hline Multnomah Channel & 11 & .1 & $<.1$ & $<.1$ & $<.1$ & .1 & .2 & .2 \\
\hline Sandy River & 4 & $<.1$ & -- & -- & $<.1$ & -- & -- & $<.1$ \\
\hline Lewis River & 4 & $<.1$ & -- & -- & $<.1$ & -- & -- & .1 \\
\hline Kalama River & 4 & $<.1$ & -- & -- & $<.1$ & -- & -- & $<.1$ \\
\hline Cowlitz River & 4 & $<.1$ & -- & -- & $<.1$ & -- & -- & $<.1$ \\
\hline All Sites & $\overline{85}$ & $\overline{<<.1}$ & $\overline{<<.1}$ & $\overline{c<1}$ & .1 & $\overline{c .1}$ & $\overline{.2}$ & $\overline{.2}$ \\
\hline \multicolumn{9}{|c|}{ Magnesium } \\
\hline Warrendale & 11 & 4.2 & 4.2 & 4.6 & 5.0 & 5.8 & 6.0 & 6.0 \\
\hline Hayden Island & 12 & 4.0 & 4.1 & 4.5 & 4.8 & 5.3 & 6.0 & 6.0 \\
\hline Columbia City & 12 & 3.7 & 3.9 & 4.2 & 4.4 & 5.2 & 6.0 & 6.1 \\
\hline Beaver & 11 & 3.8 & 3.8 & 3.9 & 4.4 & 5.1 & 5.2 & 5.2 \\
\hline Willamette River & 14 & 1.6 & 1.6 & 2.0 & 2.2 & 2.4 & 2.6 & 2.8 \\
\hline Multnomah Channel & 11 & 1.8 & 1.9 & 2.3 & 3.1 & 3.8 & 4.3 & 4.4 \\
\hline Sandy River & 1 & 2.3 & -- & -- & 2.3 & -- & -- & 2.3 \\
\hline Lewis River & 4 & 1.0 & -- & -- & 1.1 & -- & -- & 1.1 \\
\hline Kalama River & 4 & 1.2 & -- & -- & 1.5 & -- & -- & 1.5 \\
\hline Cowlitz River & 4 & 1.7 & -- & -- & 1.9 & -- & -- & 2.0 \\
\hline All Sites & 84 & 1.0 & 1.6 & 2.2 & 4.0 & 4.8 & 5.5 & 6.1 \\
\hline \multicolumn{9}{|c|}{ Potassium } \\
\hline Warrendale & 11 & 9 & .9 & 1.0 & 1.2 & 1.3 & 1.4 & 1.4 \\
\hline Hayden Island & 12 & .9 & .9 & 1.1 & 1.2 & 1.3 & 1.4 & 1.4 \\
\hline Columbia City & 12 & 0.7 & 0.8 & 1.0 & 1.1 & 1.3 & 1.3 & 1.3 \\
\hline Beaver & 11 & .9 & .9 & 1.1 & 1.2 & 1.3 & 1.3 & 1.3 \\
\hline Willamette River & 14 & .5 & .6 & .7 & .8 & .9 & 1.1 & 1.1 \\
\hline Multnomah Channel & 11 & .7 & .7 & .8 & 1.1 & 1.2 & 1.2 & 1.2 \\
\hline
\end{tabular}


Table 25. Distribution of major-ion concentrations in filtered and unfiltered water, lower Columbia River Basin, Oregon and Washington, 1994-Continued

[All measurements were performed on filtered-water samples, except specific conductance which was determined from an unfiltered-water sample; the term "filtered water" is an operational definition referring to the chemical analysis of that portion of a water-suspended sediment sample that passes through a nominal 0.45 -micrometer filter; conversely, the term "unfiltered water" refers to the chemical analysis of a water sample that has not been filtered or centrifuged, nor in any way altered from the original matrix; to avoid statistical bias that may be associated with constituents analyzed more than once at a site, only one element concentration per month was statistically summarized; values are reported in milligrams per liter, except where shown to be otherwise; see table 7 for full site names; -- indicates fewer than 6 samples collected, therefore the percentile was not calculated; <, less than]

\begin{tabular}{|c|c|c|c|c|c|c|c|c|}
\hline \multirow{2}{*}{ Site name } & \multirow{2}{*}{$\begin{array}{c}\text { Number } \\
\text { of } \\
\text { samples }\end{array}$} & \multirow{2}{*}{$\begin{array}{l}\text { Minimum } \\
\text { value }\end{array}$} & \multicolumn{5}{|c|}{ Value at indicated percentile } & \multirow{2}{*}{$\begin{array}{l}\text { Maximum } \\
\text { value }\end{array}$} \\
\hline & & & 10 & 25 & 50 & 75 & 90 & \\
\hline \multicolumn{9}{|c|}{ Potassium-Continued } \\
\hline Sandy River & 1 & .9 & -- & -- & .9 & -- & -- & .9 \\
\hline Lewis River & 4 & .4 & -- & -- & .4 & -- & -- & .4 \\
\hline Kalama River & 4 & .3 & -- & -- & .5 & -- & -- & .5 \\
\hline Cowlitz River & 4 & .7 & -- & -- & .8 & -- & -- & .8 \\
\hline All Sites & 84 & .3 & .5 & 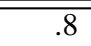 & 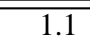 & 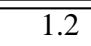 & 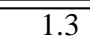 & 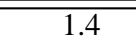 \\
\hline \multicolumn{9}{|c|}{ Silica } \\
\hline Warrendale & 11 & 5.0 & 5.3 & 7.6 & 8.5 & 8.9 & 9.6 & 9.7 \\
\hline Hayden Island & 12 & 5.4 & 5.9 & 7.4 & 8.7 & 9.7 & 10.0 & 10.0 \\
\hline Columbia City & 12 & 6.3 & 6.6 & 7.4 & 9.4 & 10.0 & 11.0 & 11.0 \\
\hline Beaver & 11 & 6.9 & 7.0 & 8.1 & 9.2 & 11.0 & 11.0 & 11.0 \\
\hline Willamette River & 12 & 13.0 & 13.0 & 14.0 & 14.5 & 16.0 & 16.7 & 17.0 \\
\hline Multnomah Channel & 11 & 8.2 & 8.5 & 10.0 & 13.0 & 15.0 & 16.8 & 17.0 \\
\hline Sandy River & 4 & 17.0 & -- & -- & 18.0 & -- & -- & 21.0 \\
\hline Lewis River & 9 & 6.5 & 6.5 & 6.7 & 6.8 & 6.9 & 7.0 & 7.0 \\
\hline Kalama River & 10 & 5.0 & 5.1 & 6.6 & 7.7 & 8.7 & 19.8 & 21.0 \\
\hline Cowlitz River & 10 & 5.3 & 5.4 & 6.4 & 6.7 & 7.1 & 13.3 & 14.0 \\
\hline All Sites & 102 & 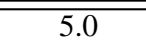 & 6.5 & 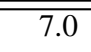 & 8.9 & $\overline{12.3}$ & 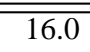 & 21.0 \\
\hline \multicolumn{9}{|c|}{ Sodium } \\
\hline Warrendale & 11 & 3.7 & 3.8 & 4.3 & 6.1 & 6.8 & 7.6 & 7.7 \\
\hline Hayden Island & 12 & 4.1 & 4.2 & 5.0 & 6.2 & 7.1 & 7.9 & 8.0 \\
\hline Columbia City & 12 & 4.0 & 4.3 & 6.0 & 6.4 & 6.9 & 7.6 & 7.8 \\
\hline Beaver & 11 & 4.8 & 5.1 & 6.3 & 7.1 & 7.5 & 7.7 & 7.7 \\
\hline Willamette River & 14 & 3.4 & 3.5 & 4.7 & 5.8 & 7.9 & 9.3 & 9.4 \\
\hline Multnomah Channel & 11 & 3.9 & 4.1 & 5.6 & 7.1 & 9.7 & 11.6 & 12.0 \\
\hline Sandy River & 1 & 5.2 & -- & -- & 5.2 & -- & -- & 5.2 \\
\hline Lewis River & 4 & 3.0 & -- & -- & 3.1 & -- & -- & 3.1 \\
\hline Kalama River & 4 & 3.1 & -- & -- & 4.3 & -- & -- & 4.9 \\
\hline Cowlitz River & 4 & 6.6 & -- & -- & 8.2 & -- & -- & 8.8 \\
\hline All Sites & 84 & 3.0 & 3.8 & 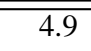 & 6.3 & $7 \overline{7.2}$ & 8.5 & 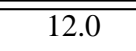 \\
\hline \multicolumn{9}{|c|}{ Specific conductance, in microsiemens per centimeter } \\
\hline Warrendale & 11 & 125.5 & 127.0 & 138.0 & 153.0 & 171.0 & 179.6 & 180.0 \\
\hline Hayden Island & 12 & 125.2 & 128.3 & 140.5 & 150.3 & 168.7 & 187.1 & 191.0 \\
\hline Columbia City & 11 & 126.1 & 126.5 & 133.3 & 145.9 & 152.2 & 172.0 & 175.0 \\
\hline
\end{tabular}


Table 25. Distribution of major-ion concentrations in filtered and unfiltered water, lower Columbia River Basin, Oregon and Washington, 1994-Continued

[All measurements were performed on filtered-water samples, except specific conductance which was determined from an unfiltered-water sample; the term "filtered water" is an operational definition referring to the chemical analysis of that portion of a water-suspended sediment sample that passes through a nominal 0.45 -micrometer filter; conversely, the term "unfiltered water" refers to the chemical analysis of a water sample that has not been filtered or centrifuged, nor in any way altered from the original matrix; to avoid statistical bias that may be associated with constituents analyzed more than once at a site, only one element concentration per month was statistically summarized; values are reported in milligrams per liter, except where shown to be otherwise; see table 7 for full site names; -- indicates fewer than 6 samples collected, therefore the percentile was not calculated; <, less than]

\begin{tabular}{|c|c|c|c|c|c|c|c|c|}
\hline \multirow{2}{*}{ Site name } & \multirow{2}{*}{$\begin{array}{c}\text { Number } \\
\text { of } \\
\text { samples }\end{array}$} & \multirow{2}{*}{$\begin{array}{l}\text { Minimum } \\
\text { value }\end{array}$} & \multicolumn{5}{|c|}{ Value at indicated percentile } & \multirow{2}{*}{$\begin{array}{l}\text { Maximum } \\
\text { value }\end{array}$} \\
\hline & & & 10 & 25 & 50 & 75 & 90 & \\
\hline \multicolumn{9}{|c|}{ Specific conductance, in microsiemens per centimeter-Continued } \\
\hline Beaver & 11 & 121.9 & 122.5 & 129.8 & 149.0 & 156.0 & 169.4 & 171.0 \\
\hline Willamette River & 14 & 56.8 & 57.8 & 77.5 & 86.0 & 93.0 & 130.5 & 158.0 \\
\hline Multnomah Channel & 11 & 61.4 & 63.7 & 83.9 & 124.7 & 138.0 & 145.9 & 147.0 \\
\hline Sandy River & 12 & 27.0 & 27.9 & 38.2 & 46.0 & 63.7 & 74.7 & 76.0 \\
\hline Lewis River & 10 & 40.0 & 40.2 & 42.7 & 45.5 & 50.0 & 54.8 & 55.0 \\
\hline Kalama River & 11 & 33.0 & 34.8 & 45.0 & 48.0 & 60.0 & 68.0 & 68.0 \\
\hline Cowlitz River & 11 & 78.0 & 78.4 & 83.0 & 98.0 & 114.0 & 115.0 & 115.0 \\
\hline All Sites & 1114 & 27.0 & 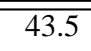 & $\overline{58.4}$ & 106.5 & $1+147.0$ & 161.5 & 191.0 \\
\hline \multicolumn{9}{|c|}{ Sulfate } \\
\hline Warrendale & 11 & 9.0 & 9.0 & 9.5 & 12.0 & 14.0 & 14.0 & 14.0 \\
\hline Hayden Island & 12 & 8.8 & 8.9 & 10.2 & 11.0 & 12.8 & 14.7 & 15.0 \\
\hline Columbia City & 12 & 9.0 & 9.2 & 9.6 & 10.5 & 12.0 & 13.7 & 14.0 \\
\hline Beaver & 11 & 9.0 & 9.2 & 10.0 & 11.0 & 12.0 & 13.8 & 14.0 \\
\hline Willamette River & 12 & 2.7 & 2.7 & 3.4 & 4.3 & 5.1 & 5.7 & 5.9 \\
\hline Multnomah Channel & 11 & 3.1 & 3.3 & 4.2 & 6.8 & 8.5 & 9.9 & 10.0 \\
\hline Sandy River & 4 & 2.6 & -- & -- & 5.0 & -- & -- & 6.4 \\
\hline Lewis River & 4 & 1.9 & -- & -- & 2.1 & -- & -- & 2.1 \\
\hline Kalama River & 4 & 1.1 & -- & -- & 1.5 & -- & -- & 1.5 \\
\hline Cowlitz River & 4 & 12.0 & -- & -- & 15.0 & -- & -- & 15.0 \\
\hline All Sites & 85 & 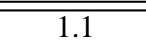 & $\overline{2.4}$ & 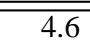 & $\overline{99.6}$ & 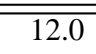 & 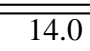 & 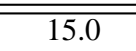 \\
\hline \multicolumn{9}{|c|}{ Total dissolved solids, residue on evaporation at 180 degrees Celsius } \\
\hline Warrendale & 11 & 77.0 & 77.2 & 85.0 & 89.0 & 100.0 & 108.6 & 109.0 \\
\hline Hayden Island & 12 & 72.0 & 74.1 & 86.2 & 90.0 & 98.7 & 114.1 & 115.0 \\
\hline Columbia City & 12 & 70.0 & 72.4 & 81.0 & 85.0 & 102.0 & 114.3 & 117.0 \\
\hline Beaver & 11 & 80.0 & 80.2 & 83.0 & 88.0 & 96.0 & 104.4 & 105.0 \\
\hline Willamette River & 14 & 34.0 & 41.5 & 54.7 & 64.5 & 77.0 & 87.5 & 89.0 \\
\hline Multnomah Channel & 11 & 56.0 & 56.4 & 60.0 & 78.0 & 82.0 & 87.6 & 88.0 \\
\hline Sandy River & 12 & 31.0 & 31.6 & 36.0 & 44.0 & 57.0 & 66.1 & 67.0 \\
\hline Lewis River & 9 & 36.0 & 36.0 & 38.0 & 40.0 & 45.0 & 75.0 & 75.0 \\
\hline Kalama River & 10 & 37.0 & 37.3 & 40.7 & 49.5 & 59.7 & 108.8 & 114.0 \\
\hline Cowlitz River & 10 & 65.0 & 65.1 & 66.7 & 74.5 & 81.7 & 88.5 & 89.0 \\
\hline All Sites & 112 & 31.0 & 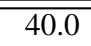 & $\overline{57.0}$ & $\overline{778.0}$ & 888.0 & 100.0 & 117.0 \\
\hline
\end{tabular}


concentrations observed in rivers throughout the world $(14,3.7,5.7,1.8,6.8,9.6$, and $81 \mathrm{mg} / \mathrm{L}$, respectively; Hem, 1989). On the basis of the historical data in the lower Columbia River Basin (STORET data retrieval, 1947-93 WY), the median concentrations of $\mathrm{Ca}, \mathrm{Mg}, \mathrm{Na}, \mathrm{K}, \mathrm{Cl}, \mathrm{SO}_{4}$, and TDS $(6.3,1.9,4.0,0.7,3.7,3.4$, and $50 \mathrm{mg} / \mathrm{L}$, respectively) historically were lower than measurements in this study. The higher concentrations in 1994 reflect the limited dilution capability of the tributaries during low-streamflow conditions. Figure 28 provides a spatial perspective of historical TDS data in the lower Columbia River Basin on the basis of their 90th-percentile values. The historical data were grouped into subbasins and units for statistical purposes only; these maps do not imply that the indicated TDS concentration existed everywhere in a given unit. The maps do show in a general way the historical TDS concentrations of different areas of the lower Columbia River Basin, as recorded by the sampling done. As expected, the highest TDS values (90th percentile: $270 \mathrm{mg} / \mathrm{L}$ ) were in the estuary where seawater mixes with river water. The next highest subbasins were the Willamette River and the Lewis River subbasins (90th percentiles: 158 and $161 \mathrm{mg} / \mathrm{L}$, respectively), while the Cowlitz River subbasin had the lowest TDS values (90th percentile: $76 \mathrm{mg} / \mathrm{L}$ ).

Specific conductance is a measure of the ability of water to conduct an electrical charge and is related to the concentration of major ions dissolved in water. In most waters, it can be related to the TDS concentration by multiplying by a factor in the range 0.55 to 0.75 (Hem, 1989, p. 67). In 1994, the median specific conductance in the Columbia River main stem ranged from $153 \mu \mathrm{S} / \mathrm{cm}$ (microsiemens per centimeter) in the Columbia River at Warrendale to $149 \mu \mathrm{S} / \mathrm{cm}$ in the Columbia River at Beaver Army Terminal (table 25). The median specific conductance during this study in the Willamette River at Portland was $86 \mu \mathrm{S} / \mathrm{cm}$. The lower specific conductance in the Willamette River was primarily a result of lower $\mathrm{Ca}, \mathrm{Mg}$, and $\mathrm{HCO}_{3}$ concentrations. The median Ca concentration in the Willamette River at Portland $(6.9 \mathrm{mg} / \mathrm{L})$, for example, was about one-half that in the Columbia River at Beaver Army Terminal.

Figure 28. Spatial distribution of 90th-percentile values for total dissolved solids by subbasin or unit, lower Columbia River Basin, Oregon and Washington, 1947-93..

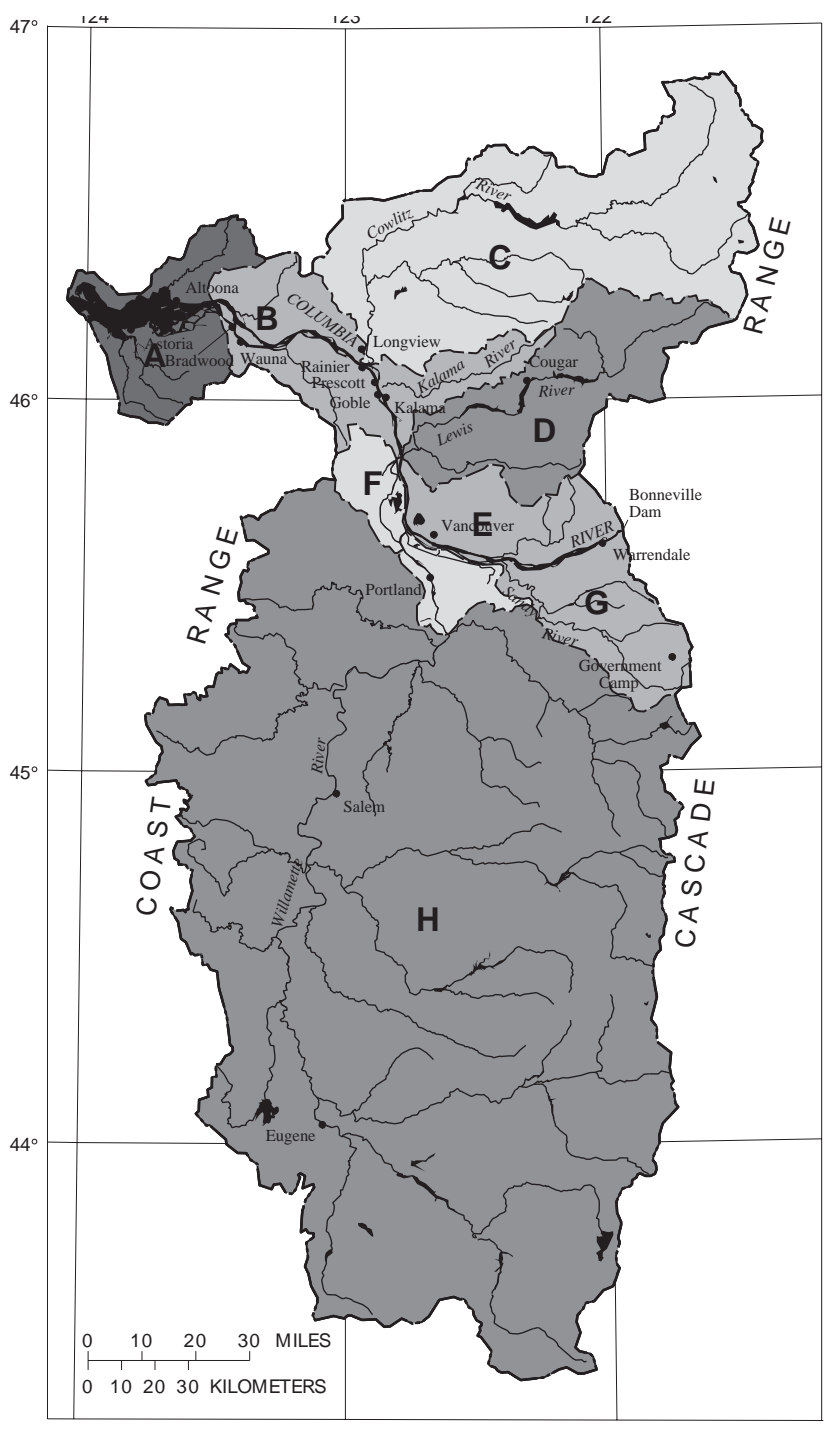

EXPLANATION

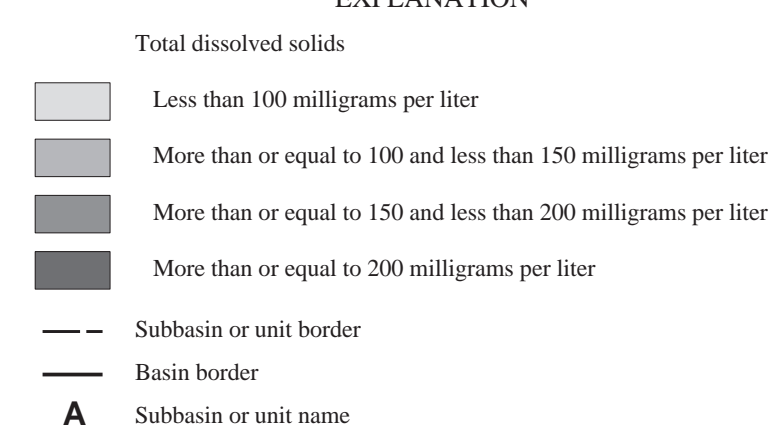

\begin{tabular}{clc}
$\begin{array}{c}\text { Map } \\
\text { Symbol }\end{array}$ & \multicolumn{1}{c}{ Subbasin or unit name } & $\begin{array}{c}\text { Number of } \\
\text { samples }\end{array}$ \\
\hline A & Lower Columbia (estuary) Unit & 30 \\
B & Lower Columiba-Clatskanie & 194 \\
C & Cowlitz River Subbasin & 26 \\
D & Lewis River Subbasin & 11 \\
E & Lower Columbia-Sandy, Washington & 29 \\
F & Lower Willamette Unit & 197 \\
G & Lower Columbia-Sandy, Oregon & 788 \\
H & Willamette River Subbasin & 424
\end{tabular}


The ionic composition of water in the lower Columbia River was relatively unchanged between Warrendale (RM 141) and Beaver Army Terminal (RM 53.8). In this reach, $\mathrm{Ca}$ and $\mathrm{Mg}$ were the dominant cations and $\mathrm{HCO}_{3}$ was the dominant anion (fig. 29). As an example, Ca accounted for as much as 60 percent of the cation milliequivalents in the Columbia River at Beaver Army Terminal. Willamette River water, however, tends to have smaller proportions of $\mathrm{Ca}$ and $\mathrm{HCO}_{3}$ and higher proportions of $\mathrm{Na}$ and $\mathrm{Cl}$ when compared to the Lower Columbia River. This may be a result of urban effects.

Although variations in median specific conductance along the main stem were small in 1994, some seasonal variations do exist. During the fall months, specific conductance decreased between the Columbia River at Warrendale and the Columbia River at Beaver Army Terminal. The specific-conductance gradient in November 1994, which was typical for October and December, showed that specific conductance decreased $37 \mu \mathrm{S} / \mathrm{cm}$ between Warrendale (RM 141) and Beaver Army Terminal (RM 53.8) (fig. 30); Ca concentrations between these sites also decreased by similar proportions. The decreasing conductivities in the fall coincide with an increase in the proportion of Willamette River water entering the main stem (RM 101.5) between Warrendale and Beaver Army Terminal. Ratios of mean daily streamflows (Willamette River at Portland: Columbia River at Warrendale) that coincide with water-quality measurements ranged from 0.68 to 0.84 in fall of 1994. These ratios underscore the diluting capability of the Willamette River's low-conductance waters. In contrast, during the summer months, the ratios of mean daily streamflows are less than 0.1 , and the discharge of low-conductance water from the Willamette River has no measurable effect on

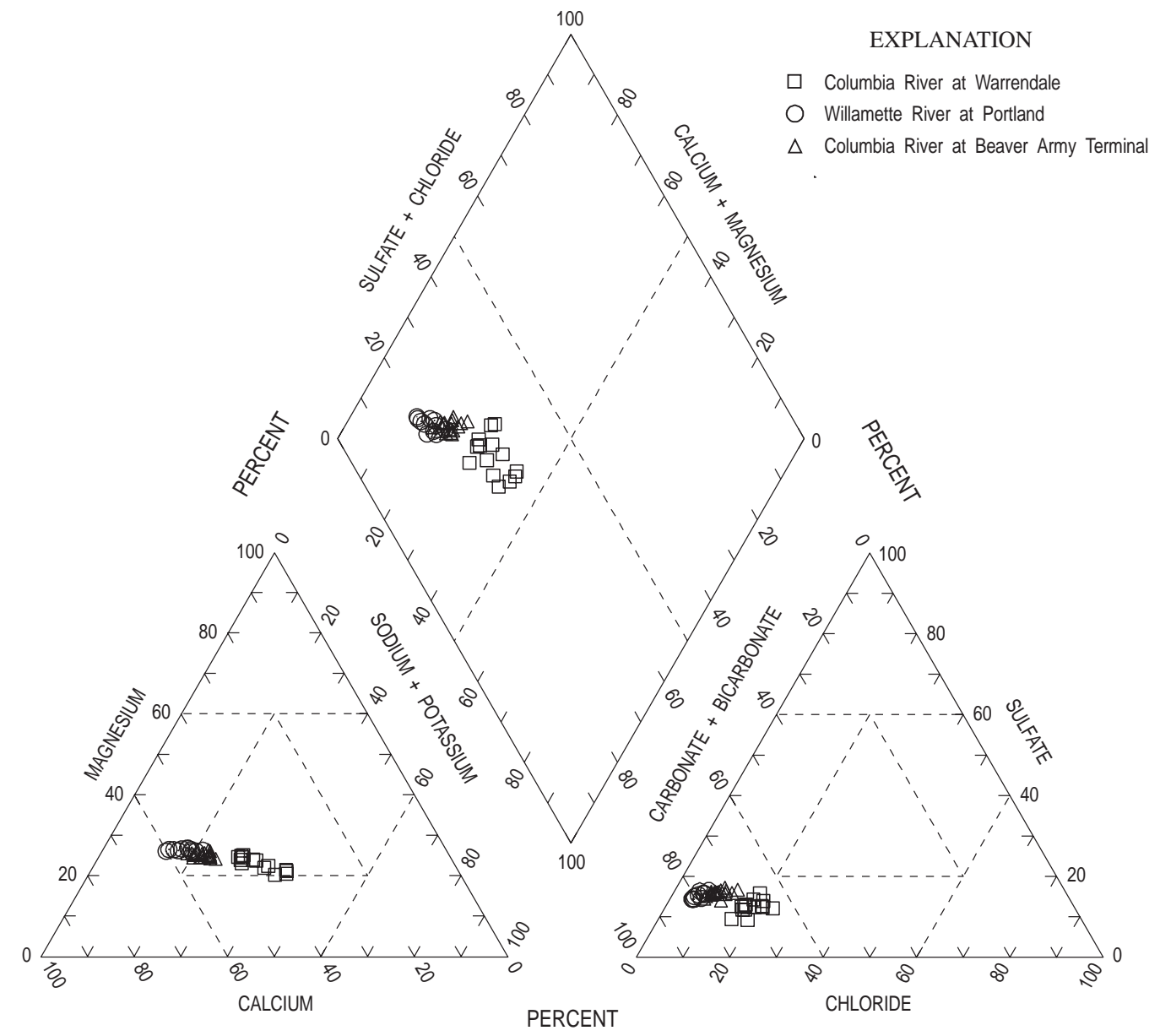

Figure 29. Major-ion composition in the Columbia River at Warrendale, Willamette River at Portland, and Columbia River at Beaver Army Terminal, lower Columbia River Basin, Oregon and Washington, 1994. 


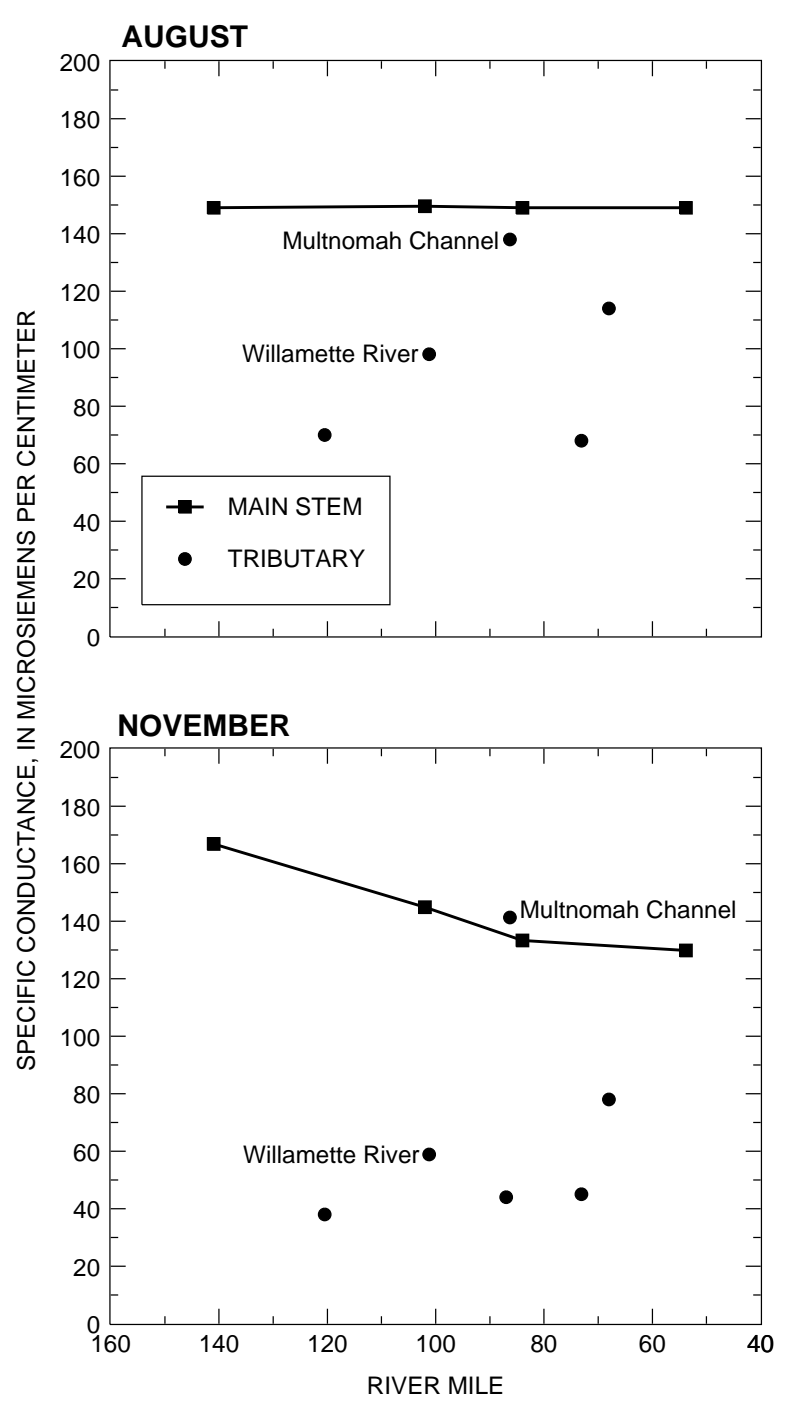

Figure 30. Specific conductance in the main stem and tributaries during August and November, lower Columbia River Basin, Oregon and Washington, 1994. (Willamette River = Willamette River at Portland, Oregon; Multnomah Channel = Multnomah Channel near mouth at St. Helens, Oregon)

specific conductance in the main stem.

Consequently, from July to September of 1994, specific conductance varied little in the main stem. In August of 1994, for example, specific conductance along the main stem is nearly constant (fig. 30).

On the basis of the hydrologic connectivity between the Willamette River and Multnomah Channel, only small differences in specific conductance might be expected between the Willamette River and Multnomah Channel. Specific conductance, however, differs considerably between these sites and at times is related to the passage of Columbia River water through Multnomah Channel and at other times is related to local point and nonpoint sources. The major-ion composition throughout Multnomah Channel is generally the same as that in the Willamette River at Portland but differs from the Columbia River near Columbia City (RM 84) (fig. 31), which is located just downstream from the mouth of the Multnomah Channel (RM 86.3). The similarity in the composition of major ions between the Willamette River and Multnomah Channel suggests that the Willamette River is the dominant source of water throughout Multnomah Channel.

Concentration distributions of $\mathrm{Ca}, \mathrm{Mg}, \mathrm{Na}, \mathrm{K}$, $\mathrm{Cl}, \mathrm{SO}_{4}$, and TDS in Multnomah Channel exceed concentrations in the Willamette River (table 25), which may reflect the influence of local point and nonpoint sources. Local point sources affecting Multnomah Channel include effluents from the City of Scappoose's sewage-treatment plant and effluents from Sauvie Island Moorage Company's sewagetreatment plant (table 46, at back of report; fig. 10). Nonpoint sources include agricultural runoff from the southern portion of Sauvie Island and along the left bank of Multnomah Channel, as well as animal wastes associated with grazing within Sauvie Island's northern wetlands area. Concentrations of $\mathrm{Na}$ and $\mathrm{Cl}$ in Multnomah Channel represent concentration maxima for the 10 sites sampled in 1994. $\mathrm{Na}$ and $\mathrm{Cl}$ are indices of human/animal wastes and commonly are associated with effluents from sewage-treatment plants (Fair and Geyer, 1954, p. 549). Concentrations of $\mathrm{Na}$ and $\mathrm{Cl}$ were highest in Multnomah Channel from May to October, a period when streamflow in the Willamette River is low and the potential effects from local point and nonpoint sources are high.

Although Columbia River water was at times present in Multnomah Channel, the Columbia River cannot account for the high major ion concentrations. From May to September, Columbia River waters may mix with waters in Multnomah Channel by flowing up the Willamette River (during high tide) and down Multnomah Channel (Rickert and others, 1976). Additionally, the lower silica concentrations, typical of Columbia River water, confirm the presence of Columbia River water in Multnomah Channel from May through September, 1994 (fig. 32). However, during the time when Columbia River water was resident in Multnomah Channel, major-ion concentrations in the Columbia 

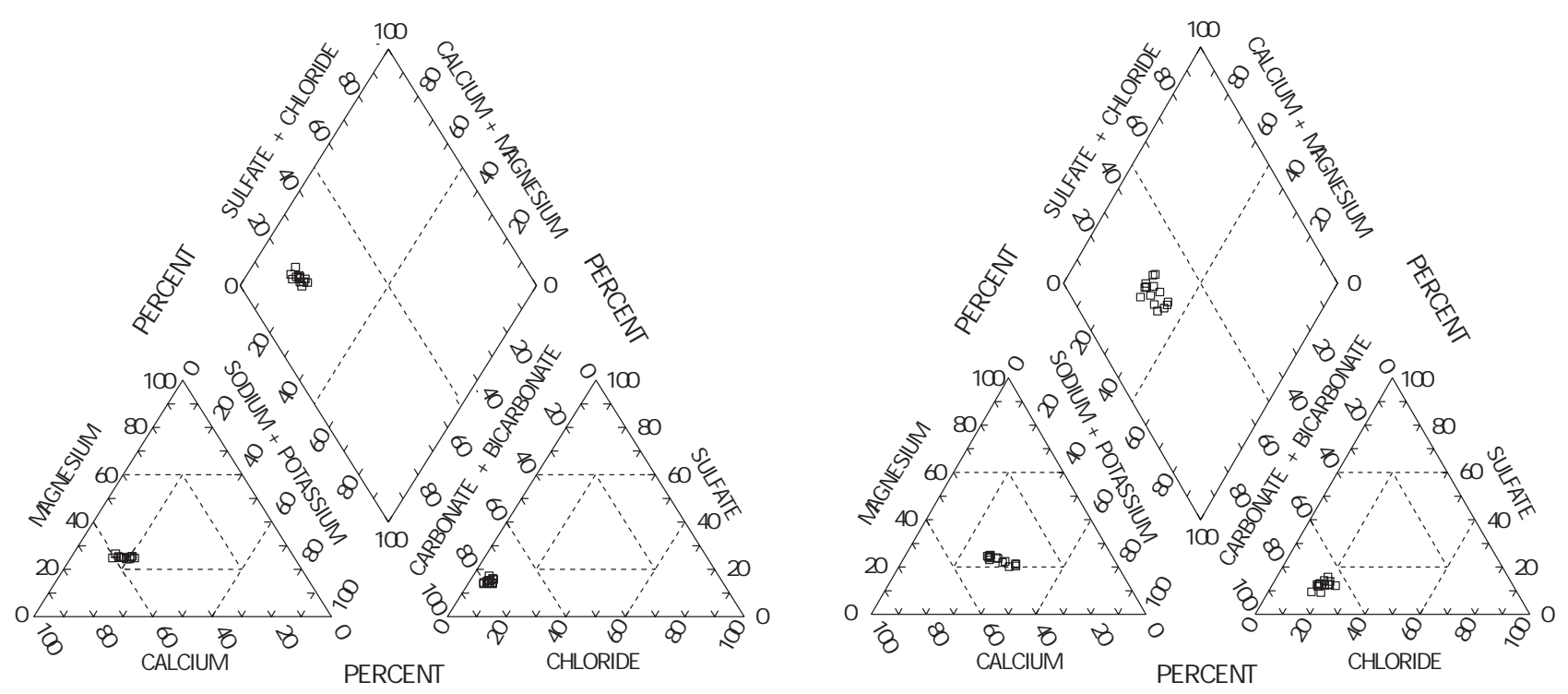

MULTNOMAH CHANNEL NEAR MOUTH AT ST. HELENS

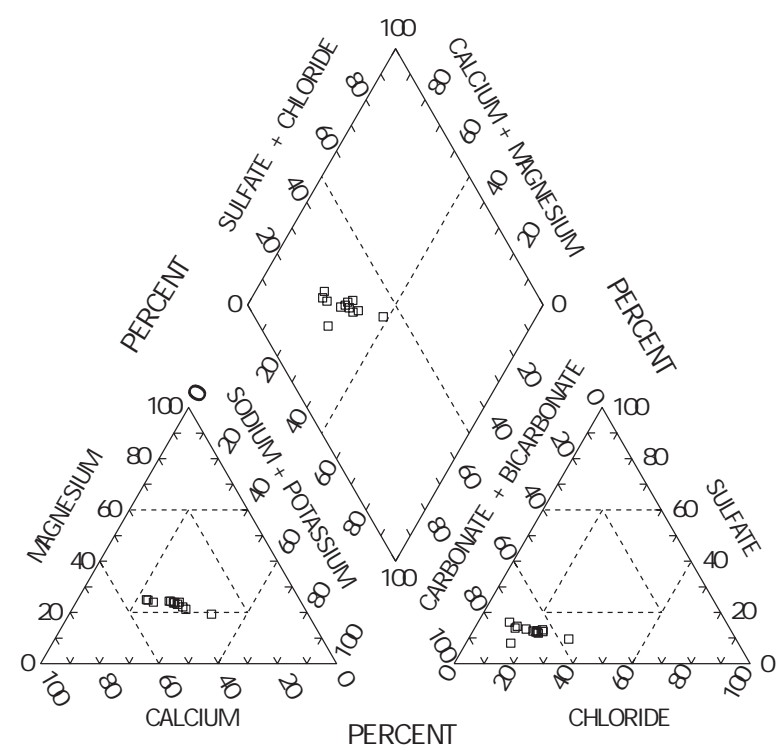

Figure 31. Major-ion composition in the Columbia River near Columbia City, Willamette River at Portland, and Multnomah Channel near mouth at St. Helens, lower Columbia River Basin, Oregon, 1994.

River at Warrendale and Columbia River at Hayden Island were small and cannot account for the high $\mathrm{Na}$ and $\mathrm{Cl}$ concentrations in Multnomah Channel. Additionally, the small $\mathrm{Na}$ and $\mathrm{Cl}$ concentrations in the Columbia River main stem in the vicinity of Portland's sewage-treatment plant (RM 105.5) suggest that $\mathrm{Na}$ and $\mathrm{Cl}$ discharges from Portland's plant are diluted, and hence, are not a source of ions to Multnomah Channel as a result of streamflowreversal processes.
Specific conductance was selected as a majorion surrogate for the purpose of examining trends in water quality; it is an overall measure of ionic composition. Results of the seasonal Kendall trend test for specific conductance for the period 1973-94 indicate that significant $(\rho<0.05)$ downward trends exist in the Columbia River at Warrendale (table 50, at back of report). Both nonflow- and flow-adjusted methods resulted in a 0.5 -percent decrease per year in the median of $160 \mu \mathrm{S} / \mathrm{cm}$. A decrease of this magnitude, for the nonflow adjusted trend, equates 


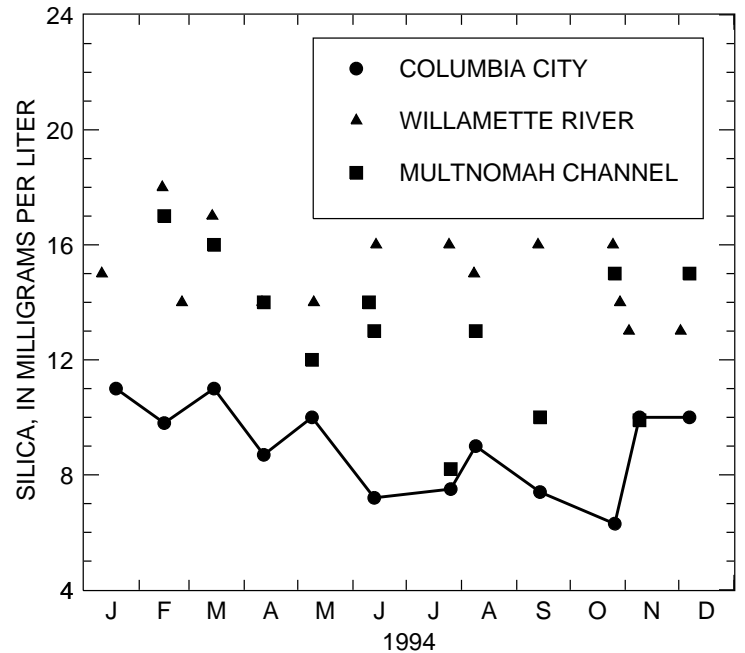

Figure 32. Concentrations of silica in the Willamette River at Portland, Multnomah Channel near mouth at St. Helens, and Columbia River near Columbia City, lower Columbia River Basin, Oregon, 1994. (Willamette River = Willamette River at Portland, Oregon; Multnomah Channel = Multnomah Channel near mouth at St. Helens, Oregon; Columbia River near Columbia City, Oregon)

to a decrease of about $1 \mu \mathrm{S} / \mathrm{cm} /$ year at Warrendale. No significant trends in specific conductance were found at the Willamette River at Portland for the period 1974-95. As expected, TDS, which is related proportionally to specific conductance, also had significant $(\rho<0.05)$ downward trends at Warrendale for both nonflow-adjusted and flowadjusted methods. The median TDS concentration $(96 \mathrm{mg} / \mathrm{L})$ for the nonflow-adjusted trends, for example, decreased by 0.6 percent per year $(-0.61$ $\mathrm{mg} / \mathrm{L} / \mathrm{year}$ ) at Warrendale for the period 1973-94.

Monthly and annual mean daily load estimates were calculated using the ESTIMATOR program for TDS in the Columbia River at Warrendale, Columbia River at Beaver Army Terminal, and Willamette River at Portland (table 26). In 1994, the annual TDS load increased between the Columbia River at Warrendale (RM 141) and the Columbia River at Beaver Army Terminal (RM 53.8). In this reach, the Willamette River alone accounted for 38 percent of the difference in annual loads between Warrendale and Beaver. Additionally, the monthly mean daily TDS loads at all three sites varied seasonally with streamflow; higher TDS loads were associated with higher streamflow conditions. In the Willamette River, for example, the high-streamflow months of fall and winter represented 76 percent of the annual streamflow and 74 percent of the annual TDS load. In contrast, the low-streamflow months of summer represented only 8 percent of the annual streamflow and 9 percent of the annual TDS load.

The Willamette River at Portland accounts for most of the difference in monthly mean daily TDS loads between the Columbia River at Warrendale and Columbia River near Beaver Army Terminal during the spring and summer months (April to September) (table 26). During these months, for example, the monthly mean daily loads in the Willamette River account for 57 to 100 percent of the difference. On average, the proportion of load contribution to the Columbia River between Warrendale and Beaver Army Terminal attributable to the Willamette River is 71 percent during the spring and summer months and 38 percent during the fall and winter months (October to March). The fall and winter month proportion is identical to that based on the annual mean daily load but is considerably different from the 71 percent during the spring and summer months. The higher proportion of load for the Willamette River during the spring and summer months probably reflects the large number of point and nonpoint sources affecting TDS in the Willamette River, in comparison to other tributaries in the lower Columbia River. The higher proportion of load contribution of the Willamette River to the Columbia River, especially in July and August (a period when streamflow on the Willamette is at its yearly low) implies that summer TDS loads were small in the other lower Columbia River tributaries. To underscore the minor effect of other lower Columbia River tributaries, the Kalama River on September 6, 1994, accounted for only 1 percent of the difference between the September mean daily loads for Warrendale and Beaver. The Cowlitz River was more significant, accounting for 34 percent of the difference in TDS load but is small in relation to the 75-percent contribution of the Willamette River.

\section{Trace Elements}

Median concentrations of most trace elements in filtered-water samples at the fixed sites sampled in 1994 were generally similar to background concentrations in North American streams, as well as concentrations found in inland waters throughout the world (table 27). Iron, however, is an exception. On the basis of historical data (1951-93), the interquartile range for iron concentrations in the lower Columbia River Basin was 20 to $130 \mu \mathrm{g} / \mathrm{L}$ and 
Table 26. Calculated monthly and annual mean daily loads for total dissolved solids at selected sites, lower Columbia River Basin, Oregon, 1994

[Loads are reported in tons per day; see table 7 for full site names; all mean daily loads estimated using ESTIMATOR (Cohn and others, 1992)]

\begin{tabular}{lcccc}
\hline \multicolumn{1}{c}{ Month } & Warrendale & Willamette & Beaver & $\frac{\text { Willamette }}{\text { Beaver - Warrendale }} \mathbf{x}$ 100 \\
\hline January & 39,000 & 6,200 & 53,000 & 44 \\
February & 45,000 & 4,700 & 56,000 & 43 \\
March & 41,000 & 5,100 & 53,000 & 42 \\
April & 43,000 & 4,000 & 50,000 & 57 \\
May & 52,000 & 2,000 & 54,000 & 100 \\
June & 43,000 & 1,900 & 46,000 & 63 \\
July & 32,000 & 1,300 & 34,000 & 65 \\
August & 21,000 & 1,300 & 23,000 & 65 \\
September & 18,000 & 1,500 & 20,000 & 75 \\
October & 24,000 & 2,100 & 29,000 & 42 \\
November & 31,000 & 6,200 & 51,000 & 31 \\
December & 39,000 & 9,700 & 77,000 & 26 \\
\hline \hline \multicolumn{1}{c}{ Annual } & 36,000 & 3,800 & 46,000 & 38 \\
\hline
\end{tabular}

far exceeded the interquartile range of 14 to $48 \mu \mathrm{g} / \mathrm{L}$ for sites sampled in 1994. The high iron concentrations, rather than being indicative of a trend over time, are the result of a disproportionately high number of sites sampled historically in the Willamette River Basin. The Willamette River, both historically and in 1994, was a source of high concentrations of filtered iron to the lower Columbia River. In 1994, for example, the interquartile range for filtered-water iron concentrations in the Willamette River at Portland was 49 to $182 \mu \mathrm{g} / \mathrm{L}$, with a maximum concentration of $290 \mu \mathrm{g} / \mathrm{L}$ (table 28). In comparison, the interquartile range for filtered-water iron concentrations in the Columbia River at Warrendale for 1994 was only 7 to $18 \mu \mathrm{g} / \mathrm{L}$. Additionally, the filtered-water iron concentration in the Willamette River collected by ODEQ on February 23, 1994, exceeded the waterquality criterion for the protection of human health (table 47, at back of report).

Arsenic was detected in several filtered-water samples in the lower Columbia River Basin. Its presence is important, because it is a known carcinogen to humans. Although median concentrations of arsenic were low $(<1 \mu \mathrm{g} / \mathrm{L}$ in 1994 and $1 \mu \mathrm{g} / \mathrm{L}$ from 1951 to 1993$)$, a distinct pattern is present when main-stem data are separated from tributary data. In 1994, for example, arsenic was consistently detected at a concentration of $1 \mu \mathrm{g} / \mathrm{L}$ in 15 of 16 filtered-water determinations at all four main-stem sites. Additionally, the detections were present over a period of 1994 that spanned both high and low streamflow conditions. Based on all arsenic determinations (main stem and tributaries) in 1994, arsenic concentrations in 38 percent of the samples exceeded ambient water-quality criteria for the protection of human health and human-health advisories for drinking water (table 47, at back of report). Based on historical data, arsenic also was detected consistently in the Columbia River at Warrendale (1974-93) at RM 141 and Columbia River at Bradwood (1974-75) at RM 38.9 (U.S. Geological Survey NWIS retrieval). The absence of detectable arsenic in filtered-water samples from tributaries of the lower Columbia River Basin and the presence of arsenic in the main stem suggests that sources of arsenic exist above the lower basin. Data collected as part of the USGS's NAWQA Program support the presence of outside sources. For example, the Yakima River (6,200 square miles of drainage), which flows into the Columbia River at RM 335.2, is an upstream source of arsenic. Monthly measurements of arsenic for the period 1987-90 at 
Table 27. Comparison of selected major- and trace-element concentrations in filtered water in the lower Columbia River Basin to surface waters worldwide

[The term "filtered water" is an operational definition referring to the chemical analysis of that portion of a water-suspended sediment sample that passes through a nominal 0.45-micrometer filter; to avoid statistical bias that may be associated with constituents analyzed more than once at a site, only one value per month was statistically summarized; values are reported in micrograms per liter; NASQAN,

National Stream Accounting Network based on data from 300 sites across the United States; <, less than; --, no data; *, percentile value below method reporting limit]

\begin{tabular}{|c|c|c|c|c|c|c|c|c|c|c|c|c|c|c|c|}
\hline \multirow{3}{*}{ Element name } & \multirow{3}{*}{$\begin{array}{l}\text { Background } \\
\text { concentrations, } \\
\text { inland waters }{ }^{a}\end{array}$} & \multirow{3}{*}{$\begin{array}{l}\text { North } \\
\text { American } \\
\text { streams b } \\
\text { (median) }\end{array}$} & \multirow{2}{*}{\multicolumn{3}{|c|}{$\begin{array}{c}\text { NASQAN } 1974-81^{\mathrm{C}} \\
\begin{array}{c}\text { Value at indicated } \\
\text { percentile }\end{array}\end{array}$}} & \multicolumn{5}{|c|}{ Lower Columbia River Basin (1951-93) } & \multicolumn{5}{|c|}{ Lower Columbia River Basin (1994) } \\
\hline & & & & & & \multirow{2}{*}{$\begin{array}{c}\text { Number } \\
\text { of } \\
\text { samples }\end{array}$} & \multicolumn{4}{|c|}{ Value at indicated percentile } & \multirow{2}{*}{$\begin{array}{l}\text { Number } \\
\text { of } \\
\text { samples }\end{array}$} & \multicolumn{4}{|c|}{ Value at indicated percentile } \\
\hline & & & 25 & 50 & 75 & & 25 & 50 & 75 & 90 & & 25 & 50 & 75 & 90 \\
\hline Aluminum & $<30$ & -- & -- & -- & -- & 511 & $*$ & 13 & 100 & 300 & 49 & 7 & 12 & 22 & 93 \\
\hline Antimony & .1 & -- & -- & -- & -- & 15 & $*$ & $*$ & $*$ & $*$ & 41 & $<1$ & $<1$ & $<1$ & $<1$ \\
\hline Arsenic & 2 & $<10$ & $<1$ & 1 & 3 & 607 & $*$ & 1 & 1 & 2 & 41 & $<1$ & $<1$ & 1 & 1 \\
\hline Beryllium & .01 & $<.3$ & -- & -- & -- & 350 & $*$ & $*$ & $*$ & $*$ & 41 & $<1$ & $<1$ & $<1$ & $<1$ \\
\hline Cadmium & .07 & 1 & -- & -- & -- & -- & -- & -- & -- & -- & 41 & $<1$ & $<1$ & $<1$ & $<1$ \\
\hline Chromium & .5 & 5.8 & -- & -- & -- & -- & -- & -- & -- & -- & 41 & $<1$ & $<1$ & $<1$ & 1.0 \\
\hline Cobalt & .05 & $<1$ & -- & -- & -- & 493 & $*$ & $*$ & $*$ & $*$ & 48 & $<1$ & $<1$ & $<1$ & $<1$ \\
\hline Copper & 1.8 & -- & -- & -- & -- & 885 & 1 & 3 & 6 & 9 & 41 & $<1$ & 1 & 2 & 2 \\
\hline Iron & $<30$ & -- & 36 & 63 & 157 & 758 & 20 & 60 & 130 & 250 & 81 & 14 & 25 & 48 & 120 \\
\hline Lead & .2 & -- & 3 & 4 & 6 & 876 & $*$ & 1 & 5 & 13.3 & 41 & $<1$ & $<1$ & $<1$ & $<1$ \\
\hline Manganese & $<5$ & -- & 11 & 24 & 51 & 1,121 & $*$ & 10 & 40 & 150 & 82 & $<1$ & 2 & 5.2 & 11 \\
\hline Mercury & .01 & (e) & -- & -- & -- & -- & -- & -- & -- & -- & 41 & $<.1$ & $<.1$ & $<.1$ & $<.1$ \\
\hline Nickel & .3 & 10 & -- & -- & -- & 527 & $*$ & $*$ & $*$ & 5.5 & 48 & $<1$ & $<1$ & $<1$ & $<1$ \\
\hline Selenium & .1 & .2 & $<1$ & $<1$ & 1 & 501 & $*$ & $*$ & $*$ & $*$ & 44 & $<1$ & $<1$ & $<1$ & $<1$ \\
\hline Silver & .3 & .3 & -- & -- & -- & 487 & $*$ & $*$ & $*$ & $*$ & 48 & $<1$ & $<1$ & $<1$ & $<1$ \\
\hline Zinc & 10 & 20 & 12 & 15 & 21 & 1,753 & $*$ & 10 & 20 & 38 & 41 & $<1$ & 1 & 2 & 4 \\
\hline
\end{tabular}

${ }^{\mathrm{a} B}$ Based on a compendium of author contributions of inland-water chemistry worldwide (Forstner and Wittmann, 1979, p. 87).

${ }^{\mathrm{b}} \mathrm{Hem}, 1989$

${ }^{c}$ Percentiles are calculated from site-mean concentrations (Smith and others, 1987).

${ }^{\mathrm{d}}$ U.S. Environmental Protection Agency's STOrage and RETrieval system (STORET), U.S. Geological Survey's National Water Information System (NWIS), and Tetra Tech, Inc., Redmond, Washington, unpub. data, 1994

${ }^{\mathrm{e}}$ Mercury concentrations rarely exceed a few tenths of a microgram per liter (Hem, 1989). 
Table 28. Distribution of major- and trace-element concentrations in filtered water, lower Columbia River Basin, Oregon and Washington, 1994

[The term "filtered water" is an operational definition referring to the chemical analysis of that portion of a water-suspended sediment sample that passes through a nominal 0.45 -micrometer filter; to avoid statistical bias that may be associated with constituents analyzed more than once at a site, only one element concentration per month was statistically summarized; values are reported in micrograms per liter; antimony, beryllium, cadmium, cobalt, lead, nickel, and selenium are not included in this table, because no samples had values greater than the method reporting limit; see table 8 for method reporting limits; see table 7 for full site names; -- indicates fewer than 6 samples were collected, therefore the percentile was not calculated; $<$, less than]

\begin{tabular}{|c|c|c|c|c|c|c|c|c|}
\hline \multirow{2}{*}{ Site name } & \multirow{2}{*}{$\begin{array}{c}\text { Number } \\
\text { of } \\
\text { samples }\end{array}$} & \multirow{2}{*}{$\begin{array}{l}\text { Minimum } \\
\text { value }\end{array}$} & \multicolumn{5}{|c|}{ Value at indicated percentile } & \multirow{2}{*}{$\begin{array}{c}\text { Maximum } \\
\text { value }\end{array}$} \\
\hline & & & 10 & 25 & 50 & 75 & 90 & \\
\hline \multicolumn{9}{|c|}{ Aluminum } \\
\hline Warrendale & 4 & 5 & -- & -- & 8 & -- & -- & 17 \\
\hline Hayden Island & 4 & 6 & -- & -- & 10 & -- & -- & 24 \\
\hline Columbia City & 5 & 6 & -- & -- & 20 & -- & -- & 34 \\
\hline Beaver & 8 & 5 & 5 & 9 & 16 & 40 & 50 & 50 \\
\hline Willamette River & 8 & 5 & 5 & 8 & 56 & 148 & 170 & 170 \\
\hline Multnomah Channel & 4 & 9 & -- & -- & 13 & -- & -- & 170 \\
\hline Sandy River & 4 & 12 & -- & -- & 14 & -- & -- & 29 \\
\hline Lewis River & 4 & 2 & -- & -- & 4 & -- & -- & 9 \\
\hline Kalama River & 4 & 6 & -- & -- & 8 & -- & -- & 10 \\
\hline Cowlitz River & 4 & 7 & -- & -- & 20 & -- & -- & 44 \\
\hline All Sites & 49 & 2 & 5 & 7 & 12 & 22 & $\overline{993}$ & 174 \\
\hline \multicolumn{9}{|c|}{ Arsenic } \\
\hline Warrendale & 4 & 1 & -- & -- & 1 & -- & -- & 1 \\
\hline Hayden Island & 4 & 1 & -- & -- & 1 & -- & -- & 1 \\
\hline Columbia City & 4 & 1 & -- & -- & 1 & -- & -- & 1 \\
\hline Beaver & 4 & $<1$ & -- & -- & 1 & -- & -- & 1 \\
\hline Willamette River & 5 & $<1$ & -- & -- & $<1$ & -- & -- & $<1$ \\
\hline Multnomah Channel & 4 & $<1$ & -- & -- & $<1$ & -- & -- & 1 \\
\hline Sandy River & 4 & $<1$ & -- & -- & $<1$ & -- & -- & $<1$ \\
\hline Lewis River & 4 & $<1$ & -- & -- & $<1$ & -- & -- & $<1$ \\
\hline Kalama River & 4 & $<1$ & -- & -- & $<1$ & -- & -- & $<1$ \\
\hline Cowlitz River & 4 & $<1$ & -- & -- & $<1$ & -- & -- & $<1$ \\
\hline All Sites & 41 & $<1$ & $<<1$ & $<<1$ & $<<1$ & 1 & 1 & 1 \\
\hline \multicolumn{9}{|c|}{ Barium } \\
\hline Warrendale & 4 & 22 & -- & -- & 24 & -- & -- & 28 \\
\hline Hayden Island & 4 & 21 & -- & -- & 23 & -- & -- & 30 \\
\hline Columbia City & 4 & 20 & -- & -- & 21 & -- & -- & 23 \\
\hline Beaver & 8 & 17 & 17 & 18 & 20 & 21 & 21 & 21 \\
\hline Willamette River & 8 & 5 & 5 & 6 & 7 & 7 & 8 & 8 \\
\hline Multnomah Channel & 4 & 6 & -- & -- & 8 & -- & -- & 11 \\
\hline Sandy River & 4 & 1 & -- & -- & 2 & -- & -- & 2 \\
\hline Lewis River & 4 & 1 & -- & -- & 1 & -- & -- & 1 \\
\hline
\end{tabular}


Table 28. Distribution of major- and trace-element concentrations in filtered water, lower Columbia River Basin, Oregon and Washington, 1994-Continued

[The term "filtered water" is an operational definition referring to the chemical analysis of that portion of a water-suspended sediment sample that passes through a nominal 0.45 -micrometer filter; to avoid statistical bias that may be associated with constituents analyzed more than once at a site, only one element concentration per month was statistically summarized; values are reported in micrograms per liter; antimony, beryllium, cadmium, cobalt, lead, nickel, and selenium are not included in this table, because no samples had values greater than the method reporting limit; see table 8 for method reporting limits; see table 7 for full site names; -- indicates fewer than 6 samples were collected, therefore the percentile was not calculated; $<$, less than]

\begin{tabular}{|c|c|c|c|c|c|c|c|c|}
\hline \multirow{2}{*}{ Site name } & \multirow{2}{*}{$\begin{array}{l}\text { Number } \\
\text { of } \\
\text { samples }\end{array}$} & \multirow{2}{*}{$\begin{array}{l}\text { Minimum } \\
\text { value }\end{array}$} & \multicolumn{5}{|c|}{ Value at indicated percentile } & \multirow{2}{*}{$\begin{array}{l}\text { Maximum } \\
\text { value }\end{array}$} \\
\hline & & & 10 & 25 & 50 & 75 & 90 & \\
\hline \multicolumn{9}{|c|}{ Barium-Continued } \\
\hline Kalama River & 4 & 1 & -- & -- & 1 & -- & -- & 2 \\
\hline Cowlitz River & 4 & 2 & -- & -- & 2 & -- & -- & 3 \\
\hline All Sites & $4 \overline{48}$ & 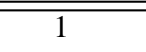 & 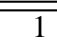 & $\overline{22}$ & $\overline{77}$ & 21 & $\overline{24}$ & 30 \\
\hline \multicolumn{9}{|c|}{ Chromium } \\
\hline Warrendale & 4 & $<1$ & -- & -- & $<1$ & -- & -- & 1 \\
\hline Hayden Island & 4 & $<1$ & -- & -- & 1 & -- & -- & 2 \\
\hline Columbia City & 4 & $<1$ & -- & -- & $<1$ & -- & -- & 1 \\
\hline Beaver & 4 & $<1$ & -- & -- & $<1$ & -- & -- & 1 \\
\hline Willamette River & 5 & $<1$ & -- & -- & $<1$ & -- & -- & $<1$ \\
\hline Multnomah Channel & 4 & $<1$ & -- & -- & $<1$ & -- & -- & 1 \\
\hline Sandy River & 4 & $<1$ & -- & -- & $<1$ & -- & -- & $<1$ \\
\hline Lewis River & 4 & $<1$ & -- & -- & $<1$ & -- & -- & $<1$ \\
\hline Kalama River & 4 & $<1$ & -- & -- & $<1$ & -- & -- & 1 \\
\hline Cowlitz River & 4 & $<1$ & -- & -- & $<1$ & -- & -- & $<1$ \\
\hline All Sites & 41 & $\overline{<1}$ & $<<1$ & $<<1$ & $\overline{<1}$ & $\overline{<<1}$ & 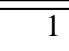 & 2 \\
\hline \multicolumn{9}{|c|}{ Copper } \\
\hline Warrendale & 4 & 1 & -- & -- & 1 & -- & -- & 3 \\
\hline Hayden Island & 4 & $<1$ & -- & -- & $<1$ & -- & -- & 2 \\
\hline Columbia City & 4 & 1 & -- & -- & 2 & -- & -- & 2 \\
\hline Beaver & 4 & $<1$ & -- & -- & 1 & -- & -- & 2 \\
\hline Willamette River & 5 & $<1$ & -- & -- & $<1$ & -- & -- & 2 \\
\hline Multnomah Channel & 4 & 1 & -- & -- & 2 & -- & -- & 3 \\
\hline Sandy River & 4 & $<1$ & -- & -- & $<1$ & -- & -- & 1 \\
\hline Lewis River & 4 & $<1$ & -- & -- & $<1$ & -- & -- & $<1$ \\
\hline Kalama River & 4 & $<1$ & -- & -- & 1 & -- & -- & 2 \\
\hline Cowlitz River & 4 & $<1$ & -- & -- & 1 & -- & -- & 2 \\
\hline All Sites & 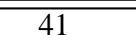 & $2<1$ & $\overline{<<1}$ & $<<1$ & $\overline{1} 1$ & 2 & 2 & 3 \\
\hline \multicolumn{9}{|c|}{ Iron } \\
\hline Warrendale & 11 & 2 & 3 & 7 & 9 & 18 & 24 & 25 \\
\hline Hayden Island & 12 & 5 & 5 & 8 & 10 & 17 & 33 & 39 \\
\hline Columbia City & 12 & 10 & 11 & 14 & 18 & 30 & 45 & 49 \\
\hline Beaver & 9 & 10 & 10 & 14 & 20 & 44 & 53 & 53 \\
\hline Willamette River & 10 & 33 & 34 & 49 & 104 & 182 & 280 & 290 \\
\hline
\end{tabular}


Table 28. Distribution of major- and trace-element concentrations in filtered water, lower Columbia River Basin, Oregon and Washington, 1994-Continued

[The term "filtered water" is an operational definition referring to the chemical analysis of that portion of a water-suspended sediment sample that passes through a nominal 0.45 -micrometer filter; to avoid statistical bias that may be associated with constituents analyzed more than once at a site, only one element concentration per month was statistically summarized; values are reported in micrograms per liter; antimony, beryllium, cadmium, cobalt, lead, nickel, and selenium are not included in this table, because no samples had values greater than the method reporting limit; see table 8 for method reporting limits; see table 7 for full site names; -- indicates fewer than 6 samples were collected, therefore the percentile was not calculated; $<$, less than]

\begin{tabular}{|c|c|c|c|c|c|c|c|c|}
\hline \multirow{2}{*}{ Site name } & \multirow{2}{*}{$\begin{array}{c}\text { Number } \\
\text { of } \\
\text { samples }\end{array}$} & \multirow{2}{*}{$\begin{array}{l}\text { Minimum } \\
\text { value }\end{array}$} & \multicolumn{5}{|c|}{ Value at indicated percentile } & \multirow{2}{*}{$\begin{array}{l}\text { Maximum } \\
\text { value }\end{array}$} \\
\hline & & & 10 & 25 & 50 & 75 & 90 & \\
\hline \multicolumn{9}{|c|}{ Iron-Continued } \\
\hline Multnomah Channel & 11 & 14 & 14 & 27 & 43 & 120 & 154 & 160 \\
\hline Sandy River & 4 & 38 & -- & -- & 53 & -- & -- & 66 \\
\hline Lewis River & 4 & 25 & -- & -- & 38 & -- & -- & 48 \\
\hline Kalama River & 4 & 17 & -- & -- & 19 & -- & -- & 20 \\
\hline Cowlitz River & 4 & 44 & -- & -- & 61 & -- & -- & 73 \\
\hline$\overline{\text { All Sites }}$ & $\overline{881}$ & 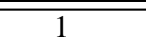 & 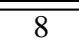 & 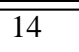 & 25 & $\overline{448}$ & 120 & 290 \\
\hline \multicolumn{9}{|c|}{ Manganese } \\
\hline Warrendale & 11 & $<1$ & $<1$ & $<1$ & $<1$ & $<1$ & 2 & 2 \\
\hline Hayden Island & 12 & $<1$ & $<1$ & 1 & 1 & 2 & 3 & 3 \\
\hline Columbia City & 12 & $<1$ & $<1$ & $<1$ & 2 & 3 & 4 & 4 \\
\hline Beaver & 9 & $<1$ & $<1$ & $<1$ & 1 & 3 & 3 & 3 \\
\hline Willamette River & 11 & $<1$ & 1 & 6 & 8 & 11 & 16 & 16 \\
\hline Multnomah Channel & 11 & $<1$ & $<1$ & 2 & 4 & 11 & 20 & 20 \\
\hline Sandy River & 4 & 3 & -- & -- & 4 & -- & -- & 4 \\
\hline Lewis River & 4 & 3 & -- & -- & 12 & -- & -- & 12 \\
\hline Kalama River & 4 & $<1$ & -- & -- & 2 & -- & -- & 4 \\
\hline Cowlitz River & 4 & 5 & -- & -- & 6 & -- & -- & 7 \\
\hline All Sites & 82 & $\overline{<1}$ & $<<1$ & $\overline{<<1}$ & 2 & $\overline{5}$ & 11 & 20 \\
\hline \multicolumn{9}{|c|}{ Mercury } \\
\hline Warrendale & 4 & $<.1$ & $\overline{--}$ & $\overline{--}$ & $<.1$ & $\overline{--}$ & $\overline{--}$ & $<.1$ \\
\hline Hayden Island & 4 & $<.1$ & -- & -- & $<.1$ & -- & -- & $<.1$ \\
\hline Columbia City & 4 & $<.1$ & -- & -- & $<.1$ & -- & -- & $<.1$ \\
\hline Beaver & 4 & $<.1$ & -- & -- & $<.1$ & -- & -- & 3.6 \\
\hline Willamette River & 5 & $<.1$ & -- & -- & $<.1$ & -- & -- & .6 \\
\hline Multnomah Channel & 4 & $<.1$ & -- & -- & $<.1$ & -- & -- & .1 \\
\hline Sandy River & 4 & $<.1$ & -- & -- & $<.1$ & -- & -- & $<.1$ \\
\hline Lewis River & 4 & $<.1$ & -- & -- & $<.1$ & -- & -- & $<.1$ \\
\hline Kalama River & 4 & $<.1$ & -- & -- & $<.1$ & -- & -- & $<.1$ \\
\hline Cowlitz River & 4 & $<.1$ & -- & -- & $<.1$ & -- & -- & $<.1$ \\
\hline All Sites & 41 & $\overline{c<.1}$ & 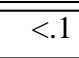 & $\overline{<<.1}$ & $\overline{<<.1}$ & $\overline{<.1}$ & $\overline{<<0.1}$ & 3.6 \\
\hline \multicolumn{9}{|c|}{ Molybdenum } \\
\hline Warrendale & 4 & $<1$ & -- & -- & $<1$ & -- & -- & 1 \\
\hline Hayden Island & 4 & $<1$ & -- & -- & $<1$ & -- & -- & 1 \\
\hline
\end{tabular}


Table 28. Distribution of major- and trace-element concentrations in filtered water, lower Columbia River Basin, Oregon and Washington, 1994-Continued

[The term "filtered water" is an operational definition referring to the chemical analysis of that portion of a water-suspended sediment sample that passes through a nominal 0.45 -micrometer filter; to avoid statistical bias that may be associated with constituents analyzed more than once at a site, only one element concentration per month was statistically summarized; values are reported in micrograms per liter; antimony, beryllium, cadmium, cobalt, lead, nickel, and selenium are not included in this table, because no samples had values greater than the method reporting limit; see table 8 for method reporting limits; see table 7 for full site names; -- indicates fewer than 6 samples were collected, therefore the percentile was not calculated; $<$, less than]

\begin{tabular}{|c|c|c|c|c|c|c|c|c|}
\hline \multirow{2}{*}{ Site name } & \multirow{2}{*}{$\begin{array}{c}\text { Number } \\
\text { of } \\
\text { samples }\end{array}$} & \multirow{2}{*}{$\begin{array}{l}\text { Minimum } \\
\text { value }\end{array}$} & \multicolumn{5}{|c|}{ Value at indicated percentile } & \multirow{2}{*}{$\begin{array}{l}\text { Maximum } \\
\text { value }\end{array}$} \\
\hline & & & 10 & 25 & 50 & 75 & 90 & \\
\hline \multicolumn{9}{|c|}{ Molybdenum-Continued } \\
\hline Columbia City & 4 & $<1$ & -- & -- & $<1$ & -- & -- & 1 \\
\hline Beaver & 8 & $<1$ & $<1$ & $<1$ & 3 & 5 & 5 & 5 \\
\hline Willamette River & 8 & $<1$ & $<1$ & $<1$ & 3 & 5 & 10 & 10 \\
\hline Multnomah Channel & 4 & $<1$ & -- & -- & $<1$ & -- & -- & $<1$ \\
\hline Sandy River & 4 & $<1$ & -- & -- & $<1$ & -- & -- & $<1$ \\
\hline Lewis River & 4 & $<1$ & -- & -- & $<1$ & -- & -- & $<1$ \\
\hline Kalama River & 4 & $<1$ & -- & -- & $<1$ & -- & -- & $<1$ \\
\hline Cowlitz River & 4 & $<1$ & -- & -- & $<1$ & -- & -- & $<1$ \\
\hline All Sites & 48 & 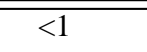 & $<<1$ & $2<1$ & $<<1$ & $<<1$ & 5 & 10 \\
\hline \multicolumn{9}{|c|}{ Uranium } \\
\hline Warrendale & 4 & $<1$ & -- & -- & $<1$ & -- & -- & $<1$ \\
\hline Hayden Island & 4 & $<1$ & -- & -- & $<1$ & -- & -- & 1 \\
\hline Columbia City & 4 & $<1$ & -- & -- & $<1$ & -- & -- & $<1$ \\
\hline Beaver & 4 & $<1$ & -- & -- & $<1$ & -- & -- & $<1$ \\
\hline Willamette River & 6 & $<1$ & $<1$ & $<1$ & $<1$ & $<1$ & $<1$ & $<1$ \\
\hline Multnomah Channel & 4 & $<1$ & -- & -- & $<1$ & -- & -- & $<1$ \\
\hline Sandy River & 4 & $<1$ & -- & -- & $<1$ & -- & -- & $<1$ \\
\hline Lewis River & 4 & $<1$ & -- & -- & $<1$ & -- & -- & $<1$ \\
\hline Kalama River & 4 & $<1$ & -- & -- & $<1$ & -- & -- & $<1$ \\
\hline Cowlitz River & 4 & $<1$ & -- & -- & $<1$ & -- & -- & $<1$ \\
\hline All Sites & 42 & $<<1$ & $<<1$ & $<<1$ & $<<1$ & $<<1$ & $<<1$ & 1 \\
\hline \multicolumn{9}{|c|}{ Zinc } \\
\hline Warrendale & 4 & $<1$ & -- & -- & $<1$ & -- & -- & 8 \\
\hline Hayden Island & 4 & $<1$ & -- & -- & 2 & -- & -- & 4 \\
\hline Columbia City & 4 & $<1$ & -- & -- & 1 & -- & -- & 2 \\
\hline Beaver & 4 & $<1$ & -- & -- & 3 & -- & -- & 14 \\
\hline Willamette River & 5 & 1 & -- & -- & 2 & -- & -- & 2 \\
\hline Multnomah Channel & 4 & 1 & -- & -- & 2 & -- & -- & 5 \\
\hline Sandy River & 4 & 1 & -- & -- & 2 & -- & -- & 2 \\
\hline Lewis River & 4 & $<1$ & -- & -- & $<1$ & -- & -- & 3 \\
\hline Kalama River & 4 & $<1$ & -- & -- & 2 & -- & -- & 2 \\
\hline Cowlitz River & 4 & $<1$ & -- & -- & $<1$ & -- & -- & 1 \\
\hline All Sites & 41 & $<1$ & $<1$ & $<1$ & 1 & 2 & 4 & 14 \\
\hline
\end{tabular}


the terminus of the Yakima River Basin had a median filtered-water arsenic concentration of $1 \mu \mathrm{g} /$ L. Additionally, 25 percent of the time, the arsenic concentration at the terminus of the basin was $2 \mu \mathrm{g} /$ $\mathrm{L}$, and waters draining agricultural fields in the Yakima River Basin had arsenic concen-trations as high as $9 \mu \mathrm{g} / \mathrm{L}$ (Fuhrer and others, in press).

In 1994, chromium was detected in 8 of 16 filtered-water samples at the 4 main-stem sites (table 29). In contrast, chromium was detected at only 2 of 6 tributary sites and in only 2 of 25 determinations. Chromium was detected most frequently in the Columbia River at Hayden Island, where three of four filtered-water samples had detectable concentrations ranging from 1 to $2 \mu \mathrm{g} / \mathrm{L}$. Several possible point sources of chromium exist along the main stem of the Columbia River. These sources include some chemical industries (Kalama Chemical [RM 74] and Wacker Siltronic Corporation [Willamette RM 6.6]), wood-treating and wood-product industries (Allweather Wood Treaters [RM 123.3] and Boise Cascade St. Helens Veneer Mill [RM 86]), aluminum industries (ALCOA [RM 103] and Reynolds Metal in Troutdale [RM 120]), and miscellaneous facilities (Pendleton Woolen Mills [RM 122.8] and the Gould Superfund site [Willamette RM 7.0]). Table 47 (at back of report) provides a more complete listing of possible point-source contributions. Chromium was detected only once in Multnomah Channel (August $8,1994)$, and its detection coincided with a time period in which surface water in the Columbia River flows up the Willamette River and down Multnomah Channel. The detection of chromium also coincides with lower silica concentrations which are indicative of the presence of Columbia River water in Multnomah Channel (see the "Major Ions and Related Measures Section" section for discussion). None of the chromium detections, however, exceeded ambient water-quality criteria or drinkingwater guidelines (table 49, at back of report).

Mercury was detected in filtered-water samples in 3 of 41 determinations (table 29). It was detected at the Multnomah Channel $(0.1 \mu \mathrm{g} / \mathrm{L})$, Willamette River at Portland $(0.6 \mu \mathrm{g} / \mathrm{L})$, and Columbia at Beaver Army Terminal $(3.6 \mu \mathrm{g} / \mathrm{L})$. Mercury was detected in the Willamette River in June and Beaver Army Terminal and Multnomah
Channel in August, with all detections occurring during low-streamflow conditions. Detections during low streamflows for most trace elements are to be expected, because trace elements discharged from point sources are diluted to a lesser extent during periods of extended low streamflow. Detections of mercury are problematic given its ubiquitous nature as a common field and laboratory contaminant (Zief and Mitchell, 1976, p. 9). The concentrations of mercury detected in this study were well above the $0.01 \mu \mathrm{g} / \mathrm{L}$ reported by Forstner and Wittmann (1979) as a background concentration for inland waters. Also, suspended-sediment samples, which were concurrently collected with filtered-water samples, lacked anomalies that would support the presence of high concentrations of filtered mercury. Despite these questions, filtered-water mercury concentrations exceeded ambient water-quality criteria and drinking-water criteria (table 47, at back of report); however, caution should be exercised in using these data given mercury's affinity to contaminate samples between the time of collection and processing and in the laboratory, prior to analysis.

In 1994 and historically, higher concentrations of filtered-water iron in the Willamette River at Portland were often associated with high streamflows which usually started in October. On November 3, 1994, for example, the filteredwater iron concentration in the Willamette River $(290 \mu \mathrm{g} / \mathrm{L})$ was 6 times that measured on September 13, 1994, during the low-streamflow period. The corresponding filtered-water iron load $(120,000$ $\mathrm{lbs} / \mathrm{d}$ [pounds per day]) on November 3, 1994, was about 50 times that measured on September 13, 1994 $(2,400 \mathrm{lbs} / \mathrm{d})$, during the low-flow period (table 30$)$. The filtered-water iron load during winter-high flows in the Willamette River also represents a large proportion of the filtered-water iron load in the Columbia River. For the November 3, 1994 sampling, the filtered-water iron load in the Willamette River is nearly 17 times that measured on November 8, 1994, in the Columbia River at Warrendale $(7,100 \mathrm{lbs} / \mathrm{d})$. The large instantaneous load and concentration of filtered-water iron in November in the Willamette River underscores the significance of the Willamette River as a source of iron during winter high streamflows. Similar concentration patterns and trends in load also exist for aluminum and, to a lesser extent, for manganese. 
Table 29. Frequency of detection of selected major and trace elements in filtered water, lower Columbia River Basin, Oregon and Washington, 1994 [Method reporting limits (MRL) are reported in micrograms per liter; see table 7 for full site names; $n$, number of samples analyzed; --, not detected]

\begin{tabular}{|c|c|c|c|c|c|c|c|c|c|c|c|}
\hline \multirow{3}{*}{$\begin{array}{c}\text { Element } \\
\text { name }\end{array}$} & \multirow{3}{*}{ MRL } & \multicolumn{4}{|c|}{ Main stem } & \multicolumn{6}{|c|}{ Tributaries } \\
\hline & & Warrendale & $\begin{array}{l}\text { Hayden } \\
\text { Island }\end{array}$ & $\begin{array}{c}\text { Columbia } \\
\text { City }\end{array}$ & Beaver & $\begin{array}{l}\text { Sandy } \\
\text { River }\end{array}$ & $\begin{array}{l}\text { Willamette } \\
\text { River }\end{array}$ & $\begin{array}{l}\text { Lewis } \\
\text { River }\end{array}$ & $\begin{array}{c}\text { Multnomah } \\
\text { Channel }\end{array}$ & $\begin{array}{l}\text { Kalama } \\
\text { River }\end{array}$ & $\begin{array}{c}\text { Cowlitz } \\
\text { River }\end{array}$ \\
\hline & & $n=4$ & $n=4$ & $n=4$ & $n=4$ & $n=4$ & $n=5$ & $n=4$ & $n=4$ & $n=4$ & $n=4$ \\
\hline Aluminum & 1 & 4 & 4 & 4 & 4 & 4 & 5 & 3 & 4 & 4 & 4 \\
\hline Antimony & 1 & -- & -- & -- & -- & -- & -- & -- & -- & -- & -- \\
\hline Arsenic & 1 & 4 & 4 & 4 & 3 & -- & -- & -- & 1 & -- & -- \\
\hline Beryllium & 1 & -- & -- & -- & -- & -- & -- & -- & -- & -- & -- \\
\hline Cadmium & 1 & -- & -- & -- & -- & -- & -- & -- & -- & -- & -- \\
\hline Chromium & 1 & 2 & 3 & 2 & 1 & -- & -- & -- & 1 & 1 & -- \\
\hline Cobalt & 1 & -- & -- & -- & -- & -- & -- & -- & -- & -- & -- \\
\hline Copper & 1 & 4 & 2 & 4 & 3 & 1 & 3 & -- & -- & 2 & 3 \\
\hline Iron & 3 & 4 & 4 & 4 & 4 & 4 & 5 & 4 & 4 & 4 & 4 \\
\hline Lead & 1 & -- & -- & -- & -- & -- & -- & -- & -- & -- & -- \\
\hline Manganese & 1 & -- & 3 & 1 & 2 & 4 & 4 & 3 & 3 & 3 & 4 \\
\hline Mercury & .1 & -- & -- & -- & 1 & -- & 1 & -- & 1 & -- & -- \\
\hline Nickel & 1 & -- & -- & -- & -- & -- & -- & -- & -- & -- & -- \\
\hline Selenium & 1 & -- & -- & -- & -- & -- & -- & -- & -- & -- & -- \\
\hline Silver & 1 & -- & -- & -- & -- & -- & -- & -- & -- & -- & -- \\
\hline Zinc & 1 & 2 & 3 & 2 & 3 & 4 & 5 & 1 & 4 & 3 & 2 \\
\hline
\end{tabular}


Table 30. Instantaneous loads for major and trace elements for selected low and high streamflow conditions in the Columbia River at Warrendale, Willamette River at Portland, and Columbia River at Beaver Army Terminal, lower Columbia River Basin, Oregon, 1994

[Loads are reported in pounds per day; $\mathrm{ft}^{3} / \mathrm{s}$, cubic feet per second; Filt., filtered load; Sus., suspended load; F/S, filtered-water load divided by suspended load; the term "filtered" is an operational definition referring to the chemical analysis of that portion of a water-suspended sediment sample that passes through a nominal 0.45-micrometer filter; --, value could not be calculated because at least one concentration was below the method reporting limit]

\begin{tabular}{|c|c|c|c|c|c|c|c|c|c|c|c|c|c|c|c|c|c|c|}
\hline \multirow{3}{*}{ 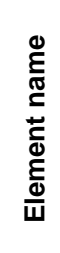 } & \multicolumn{6}{|c|}{ Columbia River at Warrendale } & \multicolumn{6}{|c|}{ Columbia River at Beaver Army Terminal } & \multicolumn{6}{|c|}{ Willamette River at Portland } \\
\hline & \multicolumn{3}{|c|}{$\begin{array}{c}\text { High streamflow } \\
\left(233,000 \mathrm{ft}^{3} / \mathrm{s}\right) \\
\text { June } 15,1994\end{array}$} & \multicolumn{3}{|c|}{$\begin{array}{c}\text { Low streamflow } \\
\left(93,800 \mathrm{ft}^{3} / \mathrm{s}\right) \\
\text { August } 8,1994\end{array}$} & \multicolumn{3}{|c|}{$\begin{array}{c}\text { High streamflow } \\
\left(234,000 \mathrm{ft}^{3} / \mathrm{s}\right) \\
\text { April } 14,1994\end{array}$} & \multicolumn{3}{|c|}{$\begin{array}{l}\text { Low streamflow } \\
\left(90,800 \mathrm{ft}^{3} / \mathrm{s}\right) \\
\text { August } 11,1994\end{array}$} & \multicolumn{3}{|c|}{$\begin{array}{c}\text { High streamflow } \\
\left(76,600 \mathrm{ft}^{3} / \mathrm{s}\right) \\
\text { November } 3,1994\end{array}$} & \multicolumn{3}{|c|}{$\begin{array}{c}\text { Low streamflow } \\
\left(9,100 \mathrm{ft}^{3} / \mathrm{s}\right) \\
\text { September 13, } 1994\end{array}$} \\
\hline & Filt. & Sus. & $\mathbf{F} / \mathbf{S}$ & Filt. & Sus. & F/S & Filt. & Sus. & F/S & Filt. & Sus. & $\mathbf{F} / \mathbf{S}$ & Filt. & Sus. & F/S & Filt. & Sus. & F/S \\
\hline $\mathrm{Al}$ & 6,000 & 920,000 & 0.01 & 4,000 & 130,000 & 0.03 & 59,000 & $1,100,000$ & 0.05 & 4,400 & 270,000 & 0.02 & 66,000 & $2,900,000$ & 0.02 & 1,000 & 18,000 & 0.06 \\
\hline $\mathrm{Sb}$ & -- & 20 & -- & -- & 4 & -- & -- & 30 & -- & -- & 4 & -- & -- & 40 & -- & -- & .2 & -- \\
\hline As & 1,000 & 100 & 10 & 500 & 20 & 25 & -- & 100 & -- & 500 & 30 & 17 & -- & 300 & -- & -- & 2 & -- \\
\hline $\mathrm{Ba}$ & 28,000 & 8,000 & 3.5 & 12,000 & 1,200 & 10 & 25,000 & 13,000 & 1.9 & 10,000 & 2,200 & 4.5 & 2,000 & 17,000 & .12 & 200 & 150 & 1.3 \\
\hline $\mathrm{Be}$ & 1,000 & -- & -- & -- & -- & -- & -- & -- & -- & -- & -- & -- & -- & 100 & -- & -- & -- & -- \\
\hline $\mathrm{Cd}$ & -- & -- & -- & -- & 4 & -- & -- & 10 & -- & -- & -- & -- & -- & 10 & -- & -- & .1 & -- \\
\hline $\mathrm{Cr}$ & -- & 700 & -- & 500 & 100 & 5 & -- & 800 & -- & 500 & 200 & 2.5 & -- & 2,400 & -- & -- & 20 & -- \\
\hline Co & -- & 200 & -- & -- & 40 & -- & -- & 300 & -- & -- & 70 & -- & -- & 900 & -- & -- & 7 & -- \\
\hline $\mathrm{Cu}$ & 1,000 & 600 & 1.7 & 500 & 100 & 5 & -- & 600 & -- & 500 & 200 & 2.5 & 800 & 2,100 & .38 & 50 & 10 & 5 \\
\hline $\mathrm{Fe}$ & 11,000 & 570,000 & .02 & 4,600 & 87,000 & .05 & 60,000 & 620,000 & .10 & 7,300 & 160,000 & .05 & 120,000 & $2,000,000$ & .06 & 2,400 & 13,000 & .18 \\
\hline $\mathrm{Pb}$ & -- & 400 & -- & -- & 70 & -- & -- & 300 & -- & -- & 100 & -- & -- & 1,200 & -- & -- & 7 & -- \\
\hline $\mathrm{Mn}$ & -- & 18,000 & -- & -- & 3,400 & -- & 800 & 14,000 & .06 & -- & 5,900 & -- & 4,100 & 64,000 & .06 & 300 & 1,000 & .30 \\
\hline $\mathrm{Hg}$ & 100 & 2 & 50 & -- & -- & -- & -- & 8 & -- & -- & .7 & -- & -- & 4 & -- & -- & .04 & -- \\
\hline Mo & -- & 8 & -- & -- & 1 & -- & -- & 20 & -- & -- & 2 & -- & -- & 30 & -- & -- & .4 & -- \\
\hline $\mathrm{Ni}$ & -- & 400 & -- & -- & 60 & -- & -- & 400 & -- & -- & 100 & -- & -- & 1,300 & -- & -- & 8 & -- \\
\hline $\mathrm{Se}$ & -- & 8 & -- & -- & -- & -- & -- & 6 & -- & -- & 2 & -- & -- & 10 & -- & -- & -- & -- \\
\hline $\mathrm{Ag}$ & -- & 4 & -- & -- & .8 & -- & -- & 9 & -- & -- & 1 & -- & -- & 10 & -- & -- & .5 & -- \\
\hline Ur & -- & 40 & -- & -- & 7 & -- & -- & 40 & -- & -- & 10 & -- & -- & 70 & -- & 1 & .8 & 1.2 \\
\hline $\mathrm{Zn}$ & -- & 3,200 & -- & 500 & 600 & .83 & 18,000 & 2,400 & 7.5 & 1,000 & 700 & 1.4 & 800 & 4,000 & .20 & 100 & 40 & 2.5 \\
\hline
\end{tabular}


The suspended-iron concentration (iron concentration associated with the suspendedsediment fraction) on November 3, 1994, in the Willamette River (6.1 percent) was about 45 percent larger than that measured on November 8, 1994 in Columbia River at Warrendale (4.2 percent). Overall, suspended-iron concentrations in the Willamette River were the highest for the 10 sites sampled in the lower Columbia River Basin in 1994 (table 31). Unlike filtered-water iron concentrations, suspended-iron concentrations were similar during the winter high flows and the summer low flows. However, suspended-sediment loads and, consequently, suspended-iron loads were much greater during periods of high flow than during periods of low flow. The respective high- and lowstreamflow concentrations of suspended iron (6.1 and 5.2 percent) on November 3 and September 13 differed by only 0.9 percent, yet the respective suspended-iron load during the high-flow sampling in November $(2,000,000 \mathrm{lbs} / \mathrm{d})$ was more than 150 times that measured in September $(13,000 \mathrm{lbs} / \mathrm{d})$ (table 30). The large difference in suspended-iron load between seasons is the result of the large differences in November and September suspendedsediment concentrations $(81 \mathrm{mg} / \mathrm{L}$ and $5 \mathrm{mg} / \mathrm{L}$, respectively) and streamflows $\left(76,000 \mathrm{ft}^{3} / \mathrm{s}\right.$ and $9,100 \mathrm{ft}^{3} / \mathrm{s}$, respectively).

The suspended form of iron is the dominant transport phase in the lower Columbia River. During high streamflows in the Columbia River at Warrendale, the suspended-iron load exceeded the filtered-water load by a factor of 50; during low streamflows, the suspended load was still dominant, exceeding the filtered-water load by a factor of 20 . Patterns similar to those for iron at Warrendale also existed at other sites sampled in 1994. Additionally, the suspended form is the major transport phase for aluminum and manganese.

The significance of tributary loads of suspended trace elements to the main stem of the Columbia River was determined by comparing instantaneous loads at tributary sites to instantaneous loads in the Columbia River at Warrendale. The summer low-streamflow months were selected as the time period for comparing loads, because they approximate steady-state streamflow conditions to a greater extent (based on present-study data) than the winter high-streamflow months. Ideally, a winter high-streamflow period would be best for comparing instantaneous loads because of the relation between suspended-sediment transport and rain-induced high streamflows; however, samples collected for use in making intersite-load comparisons in this study were sometimes separated by days and weeks. Also, during winter months, intrasite variations in both streamflow and suspended-sediment concentration can be large over periods as long as days or weeks. During the low-streamflow period, the Willamette River and the Cowlitz River were the largest contributors of suspended trace elements. For example, the suspended-silver load during the lowflow period in the Willamette River $(0.5 \mathrm{lbs} / \mathrm{d})$ was 60 percent of the suspended load at Warrendale $(0.8 \mathrm{lbs} /$ day $)$, even though the streamflow in the Willamette River was only 10 percent of the streamflow in the Columbia River at Warrendale ${ }^{5}$. The Cowlitz River had suspended loads of nickel (25 lbs/d), aluminum (23 tons/day), and antimony $(1.2 \mathrm{lb} / \mathrm{d})$ during low-flow conditions $\left(3,230 \mathrm{ft}^{3} / \mathrm{s}\right)$, which were respectively, 42 percent, 35 percent, and 30 percent of the corresponding loads at Warrendale, yet the streamflow was only 3 percent of the streamflow at Warrendale (table 30). Conversely, the Willamette River and the Cowlitz River were relatively small contributors of suspended zinc and arsenic. The suspended zinc and arsenic loads during the low-flow period in the Willamette River were 8 and 6 percent, respectively, of the suspended loads at the Columbia River at Warrendale. Percentages for suspended zinc and arsenic were similarly low in the Cowlitz River. On the basis of tributary loads during summer low-flow months, sources of suspended silver, nickel, aluminum, and antimony exist in the lower Columbia Basin and the sources of suspended zinc and arsenic exist outside of the lower basin.

Comparing transport phases (filtered-water versus suspended) for several constituents, including $\mathrm{Sb}, \mathrm{Be}, \mathrm{Cd}, \mathrm{Co}, \mathrm{Pb}, \mathrm{Hg}, \mathrm{Se}$, and $\mathrm{Ag}$, is problematic because of the large amount of censored data for filtered-water determinations. In most cases where trace elements in filtered-water samples were detected and quantified, however, the filtered-water fraction was the dominant transport phase.

\footnotetext{
${ }^{5} \mathrm{~A}$ potential point source of silver in the lower Willamette River is the EPA Gould Superfund site (a former battery manufacturing and recycling plant) managed by Canonie Environmental Services Corporation which is allowed to discharge up to $4.1 \mu \mathrm{g} / \mathrm{L}$ silver under the NPDES program (table 46, at back of report).
} 
Table 31. Distribution of major- and trace-element concentrations in suspended sediment, lower Columbia River Basin, Oregon and Washington, 1994

[Values are reported in micrograms per gram, except aluminum and iron which are in percent; see table 7 for full site names; -- indicates fewer than 6 samples collected, therefore percentile not calculated; <, less than]

\begin{tabular}{|c|c|c|c|c|c|c|c|c|}
\hline \multirow{2}{*}{ Site name } & \multirow{2}{*}{$\begin{array}{c}\text { Number } \\
\text { of } \\
\text { samples }\end{array}$} & \multirow{2}{*}{$\begin{array}{l}\text { Minimum } \\
\text { value }\end{array}$} & \multicolumn{5}{|c|}{ Value at indicated percentile } & \multirow{2}{*}{$\begin{array}{l}\text { Maximum } \\
\text { value }\end{array}$} \\
\hline & & & 10 & 25 & 50 & 75 & 90 & \\
\hline \multicolumn{9}{|c|}{ Aluminum, in percent } \\
\hline Warrendale & 4 & 6.4 & -- & -- & 6.4 & -- & -- & 6.9 \\
\hline Hayden Island & 4 & 6.5 & -- & -- & 7.2 & -- & -- & 8.6 \\
\hline Columbia City & 4 & 6.4 & -- & -- & 6.7 & -- & -- & 8.3 \\
\hline Beaver & 4 & 6.8 & -- & -- & 7.1 & -- & -- & 7.5 \\
\hline Willamette River & 4 & 7.4 & -- & -- & 8.1 & -- & -- & 8.8 \\
\hline Multnomah Channel & 4 & 7.7 & -- & -- & 8.0 & -- & -- & 9.3 \\
\hline Sandy River & 4 & 5.9 & -- & -- & 6.7 & -- & -- & 7.1 \\
\hline Lewis River & 3 & 4.3 & -- & -- & 4.7 & -- & -- & 7.4 \\
\hline Kalama River & 4 & 4.9 & -- & -- & 5.2 & -- & -- & 6.5 \\
\hline Cowlitz River & 4 & 8.0 & -- & -- & 8.2 & -- & -- & 8.7 \\
\hline 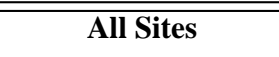 & 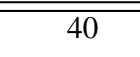 & 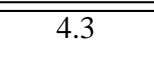 & 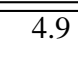 & 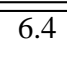 & 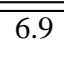 & 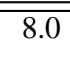 & 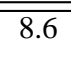 & 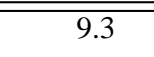 \\
\hline \multicolumn{9}{|c|}{ Iron, in percent } \\
\hline Warrendale & 4 & 4.0 & -- & -- & 4.1 & -- & -- & 4.3 \\
\hline Hayden Island & 4 & 4.1 & -- & -- & 4.7 & -- & -- & 6.1 \\
\hline Columbia City & 4 & 4.1 & -- & -- & 4.3 & -- & -- & 5.2 \\
\hline Beaver & 4 & 4.1 & -- & -- & 4.2 & -- & -- & 5.4 \\
\hline Willamette River & 4 & 5.2 & -- & -- & 5.9 & -- & -- & 6.1 \\
\hline Multnomah Channel & 4 & 5.0 & -- & -- & 5.3 & -- & -- & 6.4 \\
\hline Sandy River & 4 & 3.0 & -- & -- & 4.0 & -- & -- & 4.8 \\
\hline Lewis River & 3 & 3.8 & -- & -- & 3.9 & -- & -- & 4.2 \\
\hline Kalama River & 4 & 3.3 & -- & -- & 3.5 & -- & -- & 4.4 \\
\hline Cowlitz River & 4 & 3.7 & -- & -- & 3.9 & -- & -- & 4.3 \\
\hline All Sites & $\overline{40}$ & 3.0 & 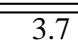 & 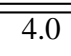 & 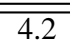 & 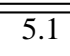 & $\overline{76.0}$ & 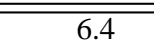 \\
\hline \multicolumn{9}{|c|}{ Antimony } \\
\hline Warrendale & 4 & 1.4 & -- & -- & 1.6 & -- & -- & 1.9 \\
\hline Hayden Island & 4 & 1.1 & -- & -- & 1.1 & -- & -- & 1.6 \\
\hline Columbia City & 4 & .9 & -- & -- & 1.3 & -- & -- & 2.0 \\
\hline Beaver & 4 & .9 & -- & -- & 1.4 & -- & -- & 2.1 \\
\hline Willamette River & 4 & .4 & -- & -- & .7 & -- & -- & 1.1 \\
\hline Multnomah Channel & 4 & .7 & -- & -- & 1.0 & -- & -- & 1.6 \\
\hline Sandy River & 4 & .4 & -- & -- & .6 & -- & -- & 4.1 \\
\hline Lewis River & 3 & .3 & -- & -- & 1.8 & -- & -- & 2.0 \\
\hline Kalama River & 4 & .4 & -- & -- & .6 & -- & -- & 7.2 \\
\hline Cowlitz River & 4 & .2 & -- & -- & .6 & -- & -- & 2.3 \\
\hline All Sites & $\overline{\overline{40}}$ & $\overline{2.2}$ & $\bar{~} .4$ & 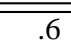 & 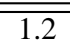 & 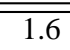 & 2.1 & $\overline{\overline{7.2}}$ \\
\hline
\end{tabular}


Table 31. Distribution of major- and trace-element concentrations in suspended sediment, lower Columbia River Basin, Oregon and Washington, 1994-Continued

[Values are reported in micrograms per gram, except aluminum and iron which are in percent; see table 7 for full site names; -- indicates fewer than 6 samples collected, therefore percentile not calculated; <, less than]

\begin{tabular}{|c|c|c|c|c|c|c|c|c|}
\hline \multirow{2}{*}{ Site name } & \multirow{2}{*}{$\begin{array}{c}\text { Number } \\
\text { of } \\
\text { samples }\end{array}$} & \multirow{2}{*}{$\begin{array}{l}\text { Minimum } \\
\text { value }\end{array}$} & \multicolumn{5}{|c|}{ Value at indicated percentile } & \multirow{2}{*}{$\begin{array}{l}\text { Maximum } \\
\text { value }\end{array}$} \\
\hline & & & 10 & 25 & 50 & 75 & 90 & \\
\hline \multicolumn{9}{|c|}{ Arsenic } \\
\hline Warrendale & 4 & 8.0 & -- & -- & 9.0 & -- & -- & 11.0 \\
\hline Hayden Island & 4 & 6.0 & -- & -- & 7.1 & -- & -- & 8.4 \\
\hline Columbia City & 4 & 6.0 & -- & -- & 8.4 & -- & -- & 8.9 \\
\hline Beaver & 4 & 6.4 & -- & -- & 8.6 & -- & -- & 11.0 \\
\hline Willamette River & 4 & 2.6 & -- & -- & 7.0 & -- & -- & 8.0 \\
\hline Multnomah Channel & 4 & 6.0 & -- & -- & 6.9 & -- & -- & 10.0 \\
\hline Sandy River & 4 & 2.2 & -- & -- & 3.6 & -- & -- & 12.0 \\
\hline Lewis River & 3 & 7.6 & -- & -- & 9.4 & -- & -- & 15.0 \\
\hline Kalama River & 4 & 3.5 & -- & -- & 4.7 & -- & -- & 5.0 \\
\hline Cowlitz River & 4 & 1.7 & -- & -- & 3.2 & -- & -- & 4.2 \\
\hline 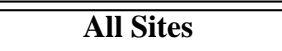 & 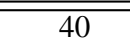 & 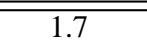 & $\overline{2.7}$ & 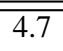 & 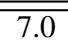 & 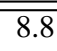 & 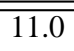 & 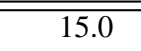 \\
\hline \multicolumn{9}{|c|}{ Beryllium } \\
\hline Warrendale & 4 & 1 & -- & -- & 1 & -- & -- & 1 \\
\hline Hayden Island & 4 & 1 & -- & -- & 2 & -- & -- & 2 \\
\hline Columbia City & 4 & 1 & -- & -- & 1 & -- & -- & 2 \\
\hline Beaver & 4 & 1 & -- & -- & 1 & -- & -- & 2 \\
\hline Willamette River & 4 & 1 & -- & -- & 2 & -- & -- & 4 \\
\hline Multnomah Channel & 4 & 1 & -- & -- & 2 & -- & -- & 3 \\
\hline Sandy River & 4 & 1 & -- & -- & 1 & -- & -- & 2 \\
\hline Lewis River & 3 & 1 & -- & -- & 1 & -- & -- & 2 \\
\hline Kalama River & 4 & 1 & -- & -- & 1 & -- & -- & 1 \\
\hline Cowlitz River & 4 & 1 & -- & -- & 1 & -- & -- & 5 \\
\hline All Sites & 40 & 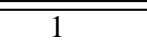 & $\overline{c 1}$ & 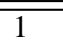 & $\overline{c 1}$ & $\overline{2}$ & 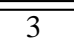 & $\overline{55}$ \\
\hline \multicolumn{9}{|c|}{ Cadmium } \\
\hline Warrendale & 4 & 1.0 & -- & -- & 2.0 & -- & -- & 2.3 \\
\hline Hayden Island & 4 & 1.0 & -- & -- & 1.7 & -- & -- & 5.1 \\
\hline Columbia City & 4 & .8 & -- & -- & 1.7 & -- & -- & 7.8 \\
\hline Beaver & 4 & .8 & -- & -- & 1.3 & -- & -- & 3.1 \\
\hline Willamette River & 4 & .3 & -- & -- & .4 & -- & -- & 1.0 \\
\hline Multnomah Channel & 4 & .3 & -- & -- & 1.0 & -- & -- & 1.0 \\
\hline Sandy River & 4 & .4 & -- & -- & 1.0 & -- & -- & 1.2 \\
\hline Lewis River & 3 & .5 & -- & -- & .6 & -- & -- & 1.0 \\
\hline Kalama River & 4 & .5 & -- & -- & .9 & -- & -- & 1.0 \\
\hline Cowlitz River & 4 & .2 & -- & -- & 1.0 & -- & -- & 1.0 \\
\hline All Sites & 40 & .2 & 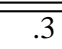 & 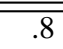 & 1.0 & 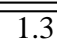 & 2.3 & 7.8 \\
\hline
\end{tabular}


Table 31. Distribution of major- and trace-element concentrations in suspended sediment, lower Columbia River Basin, Oregon and Washington, 1994-Continued

[Values are reported in micrograms per gram, except aluminum and iron which are in percent; see table 7 for full site names; -- indicates fewer than 6 samples collected, therefore percentile not calculated; <, less than]

\begin{tabular}{|c|c|c|c|c|c|c|c|c|}
\hline \multirow{2}{*}{ Site name } & \multirow{2}{*}{$\begin{array}{c}\text { Number } \\
\text { of } \\
\text { samples }\end{array}$} & \multirow{2}{*}{$\begin{array}{l}\text { Minimum } \\
\text { value }\end{array}$} & \multicolumn{5}{|c|}{ Value at indicated percentile } & \multirow{2}{*}{$\begin{array}{l}\text { Maximum } \\
\text { value }\end{array}$} \\
\hline & & & 10 & 25 & 50 & 75 & 90 & \\
\hline \multicolumn{9}{|c|}{ Chromium } \\
\hline Warrendale & 4 & 48 & -- & -- & 55 & -- & -- & 58 \\
\hline Hayden Island & 4 & 53 & -- & -- & 58 & -- & -- & 79 \\
\hline Columbia City & 4 & 56 & -- & -- & 62 & -- & -- & 72 \\
\hline Beaver & 4 & 54 & -- & -- & 56 & -- & -- & 67 \\
\hline Willamette River & 4 & 71 & -- & -- & 76 & -- & -- & 82 \\
\hline Multnomah Channel & 4 & 75 & -- & -- & 76 & -- & -- & 78 \\
\hline Sandy River & 4 & 20 & -- & -- & 33 & -- & -- & 48 \\
\hline Lewis River & 3 & 23 & -- & -- & 23 & -- & -- & 35 \\
\hline Kalama River & 4 & 49 & -- & -- & 52 & -- & -- & 62 \\
\hline Cowlitz River & 4 & 20 & -- & -- & 25 & -- & -- & 31 \\
\hline All Sites & 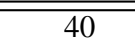 & $\overline{20}$ & 23 & 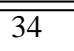 & 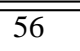 & $7 \overline{70}$ & $7 \overline{78}$ & 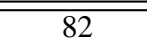 \\
\hline \multicolumn{9}{|c|}{ Copper } \\
\hline Warrendale & 4 & 30 & -- & -- & 41 & -- & -- & 59 \\
\hline Hayden Island & 4 & 37 & -- & -- & 63 & -- & -- & 86 \\
\hline Columbia City & 4 & 40 & -- & -- & 69 & -- & -- & 83 \\
\hline Beaver & 4 & 42 & -- & -- & 45 & -- & -- & 260 \\
\hline Willamette River & 4 & 51 & -- & -- & 64 & -- & -- & 110 \\
\hline Multnomah Channel & 4 & 48 & -- & -- & 56 & -- & -- & 70 \\
\hline Sandy River & 4 & 41 & -- & -- & 74 & -- & -- & 110 \\
\hline Lewis River & 3 & 45 & -- & -- & 50 & -- & -- & 91 \\
\hline Kalama River & 4 & 71 & -- & -- & 80 & -- & -- & 100 \\
\hline Cowlitz River & 4 & 41 & -- & -- & 58 & -- & -- & 66 \\
\hline 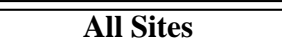 & 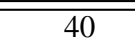 & 30 & 40 & 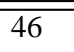 & 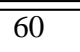 & 78 & 99 & 260 \\
\hline \multicolumn{9}{|c|}{ Lead } \\
\hline Warrendale & 4 & 26.9 & -- & -- & 32.0 & -- & -- & 49.0 \\
\hline Hayden Island & 4 & 23.7 & -- & -- & 27.0 & -- & -- & 41.0 \\
\hline Columbia City & 4 & 26.2 & -- & -- & 30.0 & -- & -- & 36.0 \\
\hline Beaver & 4 & 20.1 & -- & -- & 23.9 & -- & -- & 50.0 \\
\hline Willamette River & 4 & 7.9 & -- & -- & 22.5 & -- & -- & 33.0 \\
\hline Multnomah Channel & 4 & 24.0 & -- & -- & 31.0 & -- & -- & 49.0 \\
\hline Sandy River & 4 & 12.0 & -- & -- & 19.0 & -- & -- & 37.2 \\
\hline Lewis River & 3 & 12.0 & -- & -- & 21.0 & -- & -- & 21.0 \\
\hline Kalama River & 4 & 15.0 & -- & -- & 16.8 & -- & -- & 26.0 \\
\hline Cowlitz River & 4 & 2.2 & -- & -- & 10.2 & -- & -- & 15.0 \\
\hline All Sites & 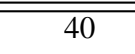 & 2.2 & 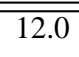 & 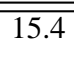 & 24.5 & 30.0 & 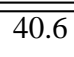 & 50.0 \\
\hline
\end{tabular}


Table 31. Distribution of major- and trace-element concentrations in suspended sediment, lower Columbia River Basin, Oregon and Washington, 1994-Continued

[Values are reported in micrograms per gram, except aluminum and iron which are in percent; see table 7 for full site names; -- indicates fewer than 6 samples collected, therefore percentile not calculated; <, less than]

\begin{tabular}{|c|c|c|c|c|c|c|c|c|}
\hline \multirow{2}{*}{ Site name } & \multirow{2}{*}{$\begin{array}{c}\text { Number } \\
\text { of } \\
\text { samples }\end{array}$} & \multirow{2}{*}{$\begin{array}{l}\text { Minimum } \\
\text { value }\end{array}$} & \multicolumn{5}{|c|}{ Value at indicated percentile } & \multirow{2}{*}{$\begin{array}{l}\text { Maximum } \\
\text { value }\end{array}$} \\
\hline & & & 10 & 25 & 50 & 75 & 90 & \\
\hline \multicolumn{9}{|c|}{ Manganese } \\
\hline Warrendale & 4 & 1,200 & -- & -- & 1,500 & -- & -- & 2,000 \\
\hline Hayden Island & 4 & 1,200 & -- & -- & 1,450 & -- & -- & 2,100 \\
\hline Columbia City & 4 & 1,200 & -- & -- & 1,450 & -- & -- & 1,800 \\
\hline Beaver & 4 & 1,100 & -- & -- & 1,400 & -- & -- & 2,000 \\
\hline Willamette River & 4 & 1,500 & -- & -- & 2,950 & -- & -- & 4,000 \\
\hline Multnomah Channel & 4 & 1,900 & -- & -- & 2,150 & -- & -- & 2,600 \\
\hline Sandy River & 4 & 900 & -- & -- & 1,500 & -- & -- & 1,700 \\
\hline Lewis River & 3 & 2,100 & -- & -- & 3,100 & -- & -- & 5,000 \\
\hline Kalama River & 4 & 1,100 & -- & -- & 1,400 & -- & -- & 1,800 \\
\hline Cowlitz River & 4 & 1,100 & -- & -- & 1,550 & -- & -- & 2,300 \\
\hline All Sites & 40 & 900 & 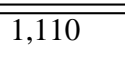 & 1,300 & 1,650 & 2,100 & 3,910 & $\overline{5,700}$ \\
\hline \multicolumn{9}{|c|}{ Mercury } \\
\hline Warrendale & 3 & .08 & -- & -- & .17 & -- & -- & .18 \\
\hline Hayden Island & 3 & .10 & -- & -- & .17 & -- & -- & 3.20 \\
\hline Columbia City & 4 & .11 & -- & -- & .14 & -- & -- & .22 \\
\hline Beaver & 4 & .10 & -- & -- & .16 & -- & -- & .54 \\
\hline Willamette River & 4 & .11 & -- & -- & .18 & -- & -- & 1.50 \\
\hline Multnomah Channel & 4 & .11 & -- & -- & .12 & -- & -- & .72 \\
\hline Sandy River & 2 & .09 & -- & -- & .12 & -- & -- & .14 \\
\hline Kalama River & 2 & .10 & -- & -- & .18 & -- & -- & .27 \\
\hline Cowlitz River & 4 & $<.02$ & -- & -- & .09 & -- & -- & .31 \\
\hline All Sites & 30 & .01 & 7.08 & .11 & .15 & .19 & .70 & 3.20 \\
\hline \multicolumn{9}{|c|}{ Nickel } \\
\hline Warrendale & 4 & 26 & -- & -- & 28 & -- & -- & 31 \\
\hline Hayden Island & 4 & 28 & -- & -- & 30 & -- & -- & 36 \\
\hline Columbia City & 4 & 29 & -- & -- & 30 & -- & -- & 34 \\
\hline Beaver & 4 & 26 & -- & -- & 28 & -- & -- & 38 \\
\hline Willamette River & 4 & 34 & -- & -- & 37 & -- & -- & 38 \\
\hline Multnomah Channel & 4 & 33 & -- & -- & 34 & -- & -- & 41 \\
\hline Sandy River & 4 & 25 & -- & -- & 26 & -- & -- & 76 \\
\hline Lewis River & 3 & 19 & -- & -- & 23 & -- & -- & 120 \\
\hline Kalama River & 4 & 29 & -- & -- & 32 & -- & -- & 96 \\
\hline Cowlitz River & 4 & 10 & -- & -- & 18 & -- & -- & 47 \\
\hline All Sites & 40 & 10 & 18 & 26 & 30 & 36 & $\overline{446}$ & 120 \\
\hline
\end{tabular}


Table 31. Distribution of major- and trace-element concentrations in suspended sediment, lower Columbia River Basin, Oregon and Washington, 1994-Continued

[Values are reported in micrograms per gram, except aluminum and iron which are in percent; see table 7 for full site names; -- indicates fewer than 6 samples collected, therefore percentile not calculated; <, less than]

\begin{tabular}{|c|c|c|c|c|c|c|c|c|}
\hline \multirow{2}{*}{ Site name } & \multirow{2}{*}{$\begin{array}{c}\text { Number } \\
\text { of } \\
\text { samples }\end{array}$} & \multirow{2}{*}{$\begin{array}{l}\text { Minimum } \\
\text { value }\end{array}$} & \multicolumn{5}{|c|}{ Value at indicated percentile } & \multirow{2}{*}{$\begin{array}{l}\text { Maximum } \\
\text { value }\end{array}$} \\
\hline & & & 10 & 25 & 50 & 75 & 90 & \\
\hline \multicolumn{9}{|c|}{ Selenium } \\
\hline Warrendale & 2 & 0.6 & -- & -- & 0.6 & -- & -- & 0.6 \\
\hline Hayden Island & 2 & .5 & -- & -- & .6 & -- & -- & .6 \\
\hline Columbia City & 3 & .5 & -- & -- & .6 & -- & -- & .6 \\
\hline Beaver & 3 & .4 & -- & -- & .6 & -- & -- & 6 \\
\hline Willamette River & 3 & .3 & -- & -- & .4 & -- & -- & .6 \\
\hline Multnomah Channel & 3 & .4 & -- & -- & .4 & -- & -- & .4 \\
\hline Sandy River & 1 & .3 & -- & -- & .3 & -- & -- & .3 \\
\hline Cowlitz River & 4 & $<.2$ & -- & -- & .4 & -- & -- & .4 \\
\hline All Sites & 21 & 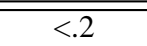 & 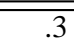 & 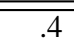 & 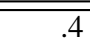 & 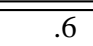 & $\overline{7.6}$ & $\bar{~} .6$ \\
\hline \multicolumn{9}{|c|}{ Silver } \\
\hline Warrendale & 4 & .3 & -- & -- & .3 & -- & -- & .6 \\
\hline Hayden Island & 4 & .2 & -- & -- & .5 & -- & -- & 6 \\
\hline Columbia City & 4 & .3 & -- & -- & .4 & -- & -- & 1.1 \\
\hline Beaver & 4 & .3 & -- & -- & .5 & -- & -- & .7 \\
\hline Willamette River & 4 & .3 & -- & -- & .6 & -- & -- & 2.0 \\
\hline Multnomah Channel & 4 & .3 & -- & -- & .5 & -- & -- & .6 \\
\hline Sandy River & 4 & .1 & -- & -- & .3 & -- & -- & .3 \\
\hline Lewis River & 3 & .1 & -- & -- & .3 & -- & -- & 1.0 \\
\hline Kalama River & 4 & .2 & -- & -- & .3 & -- & -- & .4 \\
\hline Cowlitz River & 4 & $<.1$ & -- & -- & .1 & -- & -- & .3 \\
\hline All Sites & 40 & 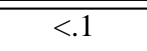 & .1 & 0.2 & 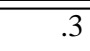 & .5 & .7 & 2.0 \\
\hline \multicolumn{9}{|c|}{ Zinc } \\
\hline Warrendale & 4 & 220 & -- & -- & 230 & -- & -- & 300 \\
\hline Hayden Island & 4 & 190 & -- & -- & 205 & -- & -- & 230 \\
\hline Columbia City & 4 & 170 & -- & -- & 240 & -- & -- & 260 \\
\hline Beaver & 4 & 160 & -- & -- & 200 & -- & -- & 270 \\
\hline Willamette River & 4 & 120 & -- & -- & 145 & -- & -- & 180 \\
\hline Multnomah Channel & 4 & 140 & -- & -- & 175 & -- & -- & 180 \\
\hline Sandy River & 4 & 81 & -- & -- & 108 & -- & -- & 220 \\
\hline Lewis River & 3 & 69 & -- & -- & 81 & -- & -- & 95 \\
\hline Kalama River & 4 & 83 & -- & -- & 106 & -- & -- & 320 \\
\hline Cowlitz River & 4 & 67 & -- & -- & 79 & -- & -- & 86 \\
\hline All Sites & 40 & 67 & 76 & 88 & 170 & 220 & 259 & 320 \\
\hline
\end{tabular}


Trace elements transported predominantly in the filtered-water phase in the lower Columbia River include arsenic, barium, chromium, and copper (table 30). Although the filteredwater:suspended ratios for loads always exceeded one for these elements, they varied with streamflow. Consider arsenic, which had higher filteredwater:suspended ratios during summer low streamflows in the lower Columbia River and lower ratios during spring high streamflows. In the Columbia River at Warrendale, for example, the filtered-water:suspended ratios for arsenic for high and low streamflows, respectively, were 13 and 25 . This same pattern of higher filtered-water loads during low streamflows in the main stem was repeated at all main-stem sites and resulted from low suspended-sediment concentrations, which are typical of low-streamflow conditions in the main stem. When suspended-sediment concentrations are low, the related transport of suspended arsenic is low and hence the filtered-water:suspended load is also low.

The dominant transport phase for some elements alternated from filtered-water to suspended depending on streamflow conditions. For example, during winter high flows in the Willamette River at Portland, the filtered-water zinc phase is one-fifth the suspended phase. During summer low streamflows, however, loads shift, and the filteredwater phase is 2.5 times the suspended phase (table 30 ). These shifts are not attributable to seasonal variations in concentrations of filtered-water or suspended zinc; rather, they result from seasonal variations in suspended-sediment concentration. In the case of the Willamette River, the suspendedsediment concentration during the November 3, 1994, high-flow sampling was $81 \mathrm{mg} / \mathrm{L}$, whereas it was only $5 \mathrm{mg} / \mathrm{L}$ during the September 13, 1994, low-flow sampling. These shifts in suspendedsediment concentration have a paramount effect on suspended-zinc loads. These same effects were not prominent in the main stem, however. The lack of shifts in the main stem was probably a result of less dynamic suspended-sediment concentrations-a characteristic of the numerous reservoirs in the main stem which minimize peak streamflow and result in less resuspension/scouring, and which provide conditions for settling of particulates in forebays and their regulating effect on peak streamflow. Similar transport-phase shifts also were measured for barium and copper.
The transport dynamics of suspended aluminum and zinc were studied by computing suspended loads over three reaches of the main stem. The suspended loads were determined based on data collected during a low-streamflow period from August through September 1994. Aluminum was selected because of its natural abundance, and zinc was selected because it is a trace contaminant often associated with human activities. For each reach, the measured load at the downstream site (site-measured load) was compared to the calculated load for the reach (reach-calculated load), and the difference between the two was computed (table 32). This type of analysis is termed mass balance. The smaller the difference between the site-measured load and the reach-calculated load, the better the mass balance is for the reach. For comparison, mass-balance calculations also were made for streamflow, a relatively conservative measure. A positive difference between measured and calculated suspended-zinc loads or streamflows implies that unmeasured contributions (from point or nonpoint sources and [or] resuspension and transport of zinc-affected streambed sediment, for example) to the site-measured load exist, whereas a negative difference implies that unaccountable losses (from suspended-sediment deposition, for example) exist in the reach. As mentioned earlier, samples that were collected during the low-streamflow months and used in making intersite-load comparisons were sometimes separated by days or weeks.

Consequently, variability in daily mean streamflow and daily concentrations can contribute to differences that were observed between sitemeasured and reach-calculated loads.

Between the Columbia River at Warrendale (RM 141) and the Columbia River near Columbia City (RM 84), the site-measured zinc load differed from the reach-calculated load by $+25 \mathrm{lbs} / \mathrm{d}$. This difference in load is small (about 3 percent of the site-measured load at Columbia City) and indicates a good mass balance over the Warrendale to Columbia City reach. The major contributing tributary over this reach is the Willamette River. It has a suspended-zinc load (39 lbs/d) that is small in comparison to the $610 \mathrm{lbs} / \mathrm{d}$ of suspended-zinc entering the lower Columbia River at Warrendale. Between Columbia City and the Columbia River at Beaver Army Terminal, the difference between the site-measured load and reach-calculated load is small (+13 lbs/d), and again, is indicative of a good 
Table 32. Mass balances for streamflow, suspended zinc loads, and suspended aluminum loads, lower Columbia River Basin, Oregon and Washington, August through September, 1994

[Loads were determined from instantaneous measurements of suspended aluminum and zinc concentrations made during a low-streamflow period and daily mean streamflow for the day the suspended-trace element sample was collected; $\mathrm{ft}^{3} / \mathrm{s}$, cubic feet per second; lb/d, pounds per day; --, not applicable; nd, no data; see table 7 for full site names; see page 95 for a discussion of the mass-balance approach]

\begin{tabular}{|c|c|c|c|c|c|c|c|c|c|c|c|c|c|c|}
\hline \multirow[b]{3}{*}{ Site name } & \multirow[b]{3}{*}{$\begin{array}{l}\text { Sampling } \\
\text { date }\end{array}$} & \multirow[b]{3}{*}{$\begin{array}{l}\text { Columbia } \\
\text { river } \\
\text { mile }\end{array}$} & \multicolumn{4}{|c|}{ Streamflow $\left(\mathrm{ft}^{3} / \mathrm{s}\right)$} & \multicolumn{4}{|c|}{ Suspended zinc load (lb/d) } & \multicolumn{4}{|c|}{ Suspended aluminum load (tons/d) } \\
\hline & & & \multicolumn{3}{|c|}{ Main Stem } & \multirow[b]{2}{*}{ 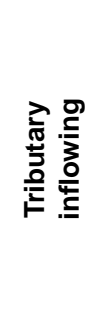 } & \multicolumn{3}{|c|}{ Main stem } & \multirow[b]{2}{*}{ 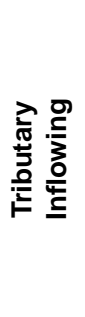 } & \multicolumn{3}{|c|}{ Main stem } & \multirow[b]{2}{*}{ 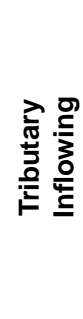 } \\
\hline & & & 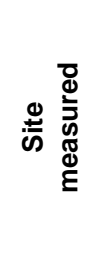 & 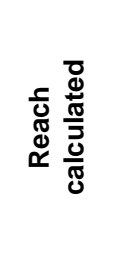 & 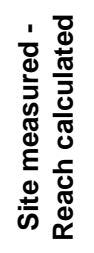 & & 心 & 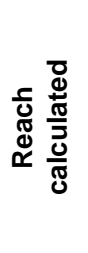 & 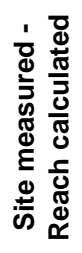 & & 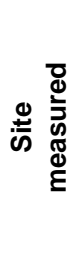 & 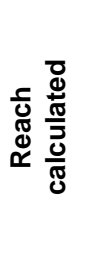 & 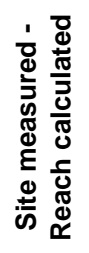 & \\
\hline Warrendale & 08-10-1994 & 141 & 93,800 & -- & -- & -- & 610 & -- & -- & -- & 65 & -- & -- & -- \\
\hline Sandy River & 08-15-1994 & 120.5 & -- & -- & -- & 570 & -- & -- & -- & 5.4 & -- & -- & -- & 0.9 \\
\hline Hayden Island & nd & 102 & nd & nd & nd & -- & nd & nd & nd & -- & nd & nd & nd & -- \\
\hline Willamette River & 09-13-1994 & 101.5 & -- & -- & -- & 9,000 & -- & -- & -- & 39 & -- & -- & -- & 9.1 \\
\hline Lewis River & 09-07-1994 & 87 & -- & -- & -- & 1,250 & -- & -- & -- & .6 & -- & -- & -- & .1 \\
\hline Columbia City & 09-14-1994 & 84 & 97,000 & 104,620 & $\begin{array}{c}- \\
7,620\end{array}$ & -- & 680 & 655 & +25 & -- & 89 & 75.1 & +13.9 & -- \\
\hline Kalama River & 08-17-1994 & 73.1 & -- & -- & -- & 200 & -- & -- & -- & 1.0 & -- & -- & -- & .05 \\
\hline Cowlitz River & 08-31-1994 & 68 & -- & -- & -- & 3,230 & -- & -- & -- & 46.4 & -- & -- & -- & 23 \\
\hline Beaver Army Terminal & 08-11-1994 & 53.8 & 90,800 & 100,430 & $\begin{array}{c}- \\
9,630\end{array}$ & -- & 740 & 727 & +13 & -- & 130 & 112 & +18 & -- \\
\hline
\end{tabular}


mass balance for suspended zinc. The major contributing tributary over this reach is the Cowlitz River, which has a suspended-zinc load (46 lbs/d) that is slightly larger than that of the Willamette River but small in comparison to the load at Warrendale. The difference in load between the Willamette River and the Cowlitz River results from a higher concentration of suspended sediment in the Cowlitz River, rather than a higher concentration of suspended zinc. The general agreement between site measured and reach calculated loads (good mass balance) is indicative of a sampling network that spatially is adequate to account for major sources of trace elements in the lower Columbia River Basin. The good mass balance, however, is limited to lowstreamflow periods in late summer. The degree of mass balance during high streamflow periods is unknown. Depending on the magnitude of the high streamflows, mass balance may be affected by resuspension and transport between reaches and by load contributions from episodic point sources.

\section{Organic Compounds}

Water samples in the lower Columbia River Basin were analyzed for organic compounds beginning in 1965. This limited period of record and the high cost of analysis explain why the number of determinations for organic compounds is much smaller than those for other constituents addressed in this report. Of the 82 organic compounds analyzed historically, 32 were not detected and 56 had fewer than 10 detections (table 33).

Organic compounds were detected at 7 of the 10 sites in 1994; data for sites with detections are listed in table 34 . The organic compounds analyzed, including common name, application, and pesticide class are shown in table 35 . Of the 47 organic compounds analyzed, 20 were detected in this study. Organic compounds were detected at all four main-stem sites and at three of the six tributary sites. The Willamette River at Portland had the largest number of detections, and, of the 20 organic compounds detected in the lower Columbia River Basin, all were detected at one time or another in the Willamette River. Sites without any detections of organic compounds were the Sandy River near Troutdale, Kalama River above Spencer Creek near Kalama, and Cowlitz River at Kelso.
In addition to determinations of the 47 organic compounds listed above, a second suite of 41 organic compounds was analyzed using a high performance liquid chromatography (HPLC) method which is presently under development by the USGS. Quality assurance for this new method is under review by the USGS's Methods Development Group. The USGS is reviewing analytical-method performance, issues related to sample preservation and sample degradation, potential for saturation of the solidphase adsorbent cartridge and subsequent loss of analyte prior to analysis, lapsed time between sample extraction from the solid-phase cartridge and sample analysis, potential for coelution of analytes, and other factors that ultimately affect the quality of the reported organic-compound data. Consequently, the second suite of organic compounds were unavailable for use in the current study. Preliminary results, however, show that only a limited number of organic compounds were detected and that false positive detections are not a problem with the method. Of the 45 samples analyzed using HPLC in 1994, only 6 detections were reported in the Willamette River and Columbia River near Beaver Army Terminal. These six detections represent five organic compounds: dicamba, 2,4-D, diuron, 1-naphthol, and carbaryl.

Atrazine, a triazine herbicide and the most frequently detected organic compound in the lower Columbia River Basin, was detected in 23 of 45 samples (fig. 33). The herbicides metolachlor and simazine, the next most frequently detected organic compounds, were detected in 17 and 16 of 45 samples, respectively. The largest concentrations of atrazine, metolachlor, and simazine were measured in the Willamette River at Portland. Atrazine concentrations in the Willamette River, for example, ranged from 0.01 to $0.18 \mu \mathrm{g} / \mathrm{L}$, and the median concentration $(0.033 \mu \mathrm{g} / \mathrm{L})$ was more than 10 times the median concentrations found at the four mainstem sites (table 36). The atrazine metabolite, deethylatrazine, was detected in 9 of 45 determinations, and 8 of the 9 detections were in the Willamette River and Multnomah Channel. None of the atrazine concentrations measured in the lower Columbia River Basin, however, exceeded the EPA's lifetime health advisory level of $3 \mu \mathrm{g} / \mathrm{L}$. Additionally, none of the organic compounds measured in the lower Columbia River Basin in 1994 exceededthe EPA's ambient water-quality criteria or drinkingwater guidelines (table 49, at back of report). 
Table 33. Number of historical determinations and uncensored data values for organic compounds, lower Columbia River Basin, Oregon and Washington, 1965-93

[All compounds listed are in filtered water unless otherwise stated; the term "filtered water" is an operational definition referring to the chemical analysis of that portion of a water-suspended sediment sample that passes through a nominal 0.70-micrometer filter; conversely, the term "unfiltered water" refers to the chemical analysis of a water sample that has not been filtered or centrifuged, nor in any way altered from the original matrix; STORET, U.S. Environmental Protection Agency's STOrage and RETrieval system; 2, 4-D, (2,4- dichlorophenoxy) acetic acid; 2,4-DB, 4-(2,4-dichlorophenoxy)butyric acid; DCPA, 3',4'dichloropropionanilide; DDE, dichlorodiphenyldichloroethylene; EPTC, S-ethyl dipropyl thiocarbamate; HCH, hexachlorocyclohexane; MCPA, (4-chloro-2methylphenoxy) acetic acid; MCPB, 4-(4-chloro-2-methylphenoxy) butyric acid; 2,4,5-T, (2,4,5-trichlorophenoxy) acetic acid; --, not applicable or not available]

\begin{tabular}{|c|c|c|c|c|}
\hline $\begin{array}{l}\text { STORET } \\
\text { code }\end{array}$ & Compound name & $\begin{array}{c}\text { Chemical Abstracts Services } \\
\text { registry number }\end{array}$ & $\begin{array}{c}\text { Number of historical } \\
\text { determinations }\end{array}$ & $\begin{array}{c}\text { Number of uncensored } \\
\text { data values }\end{array}$ \\
\hline 49315 & Acifluorfen & 50594-66-6 & 231 & 0 \\
\hline 46342 & Alachlor & $15972-60-8$ & 303 & 20 \\
\hline 49312 & Aldicarb & $116-06-3$ & 228 & 0 \\
\hline 49313 & Aldicarb sulfone & $1646-88-4$ & 228 & 0 \\
\hline 49314 & Aldicarb sulfoxide & -- & 228 & 0 \\
\hline 39632 & Atrazine & $1912-24-9$ & 309 & 252 \\
\hline 39630 & Atrazine, unfiltered & $1912-24-9$ & 21 & 9 \\
\hline 82686 & Azinphos-methyl & $86-50-0$ & 284 & 5 \\
\hline 82673 & Benfluralin & $1861-40-1$ & 288 & 2 \\
\hline 38711 & Bentazon & $25057-89-0$ & 231 & 7 \\
\hline 04029 & Bromacil & $314-40-9$ & 247 & 5 \\
\hline 49311 & Bromoxynil & $1689-84-5$ & 231 & 2 \\
\hline 04028 & Butylate & $2008-41-5$ & 288 & 0 \\
\hline 49310,82680 & Carbaryl & $63-25-2$ & 516 & 72 \\
\hline 49309 & Carbofuran & $1563-66-2$ & 228 & 19 \\
\hline 49306 & Chlorothalonil & $1897-45-6$ & 228 & 0 \\
\hline 38933 & Chlorpyrifos & $2921-88-2$ & 296 & 94 \\
\hline 49305 & Clopyralid & $1702-17-6$ & 231 & 0 \\
\hline 04041 & Cyanazine & $21725-46-2$ & 303 & 1 \\
\hline 39732 & $2,4-\mathrm{D}$ & $94-75-7$ & 251 & 24 \\
\hline 39730 & 2,4-D, unfiltered & $94-75-7$ & 62 & 39 \\
\hline 49304 & Dacthal & $1861-32-1$ & 231 & 0 \\
\hline 38746 & 2,4-DB & $94-82-6$ & 231 & 0 \\
\hline 82682 & DCPA & $1861-32-1$ & 288 & 93 \\
\hline 34653 & p,p'-DDE & $72-55-9$ & 288 & 13 \\
\hline 04040 & Deethylatrazine & $6190-65-4$ & 303 & 137 \\
\hline 39572 & Diazinon & $333-41-5$ & 298 & 159 \\
\hline 38442 & Dicamba & $1918-00-9$ & 231 & 3 \\
\hline 49303 & Dichlobenil & $1194-65-6$ & 228 & 4 \\
\hline 49302 & Dichlorprop & $120-36-5$ & 231 & 0 \\
\hline 39381 & Dieldrin & $60-57-1$ & 297 & 8 \\
\hline 82660 & 2,6-Diethylaniline & $91-66-7$ & 288 & 0 \\
\hline 82662 & Dimethoate & $60-51-5$ & 234 & 5 \\
\hline 49301 & Dinoseb & $88-85-7$ & 231 & 8 \\
\hline 82677 & Disulfoton & 298-04-4 & 288 & 0 \\
\hline 49300 & Diuron & $330-54-1$ & 228 & 103 \\
\hline 82668 & EPTC & $759-94-4$ & 288 & 115 \\
\hline 49298 & Esfenvalerate & $66230-04-4$ & 228 & 0 \\
\hline 82663 & Ethalfluralin & $55283-68-6$ & 288 & 0 \\
\hline 82672 & Ethoprop & $13194-48-4$ & 288 & 77 \\
\hline 39762 & Fenoprop (silvex) & $93-72-1$ & 250 & 0 \\
\hline 49297 & Fenuron & $101-42-8$ & 228 & 0 \\
\hline 38811 & Fluometuron & $2164-17-2$ & 228 & 0 \\
\hline 04095 & Fonofos & $944-22-9$ & 295 & 68 \\
\hline 34253 & alpha-HCH & $319-84-6$ & 288 & 0 \\
\hline 39341 & gamma-HCH (lindane) & $58-89-9$ & 297 & 23 \\
\hline
\end{tabular}


Table 33. Number of historical determinations and uncensored data values for organic compounds, lower Columbia River Basin, Oregon and Washington, 1965-93-Continued

[All compounds listed are in filtered water unless otherwise stated; the term "filtered water" is an operational definition referring to the chemical analysis of that portion of a water-suspended sediment sample that passes through a nominal 0.70-micrometer filter; conversely, the term "unfiltered water" refers to the chemical analysis of a water sample that has not been filtered or centrifuged, nor in any way altered from the original matrix; STORET, U.S. Environmental Protection Agency's STOrage and RETrieval system; 2, 4-D, (2,4- dichlorophenoxy) acetic acid; 2,4-DB, 4-(2,4-dichlorophenoxy)butyric acid; DCPA, 3',4'dichloropropionanilide; DDE, dichlorodiphenyldichloroethylene; EPTC, S-ethyl dipropyl thiocarbamate; HCH, hexachlorocyclohexane; MCPA, (4-chloro-2methylphenoxy) acetic acid; MCPB, 4-(4-chloro-2-methylphenoxy) butyric acid; 2,4,5-T, (2,4,5-trichlorophenoxy) acetic acid; --, not applicable or not available]

\begin{tabular}{|c|c|c|c|c|}
\hline $\begin{array}{l}\text { STORET } \\
\text { code }\end{array}$ & Compound name & $\begin{array}{c}\text { Chemical Abstracts Services } \\
\text { registry number }\end{array}$ & $\begin{array}{c}\text { Number of historical } \\
\text { determinations }\end{array}$ & $\begin{array}{c}\text { Number of uncensored } \\
\text { data values }\end{array}$ \\
\hline 49308 & 3-Hydroxycarbofuran & -- & 228 & 0 \\
\hline 38478,82666 & Linuron & $330-55-2$ & 576 & 1 \\
\hline 39532 & Malathion & $121-75-5$ & 297 & 27 \\
\hline 38482 & MCPA & $94-74-6$ & 231 & 2 \\
\hline 38487 & MCPB & $94-81-5$ & 231 & 0 \\
\hline 38501 & Methiocarb & $2032-65-7$ & 228 & 2 \\
\hline 49296 & Methomyl & $16752-77-5$ & 228 & 0 \\
\hline 82667 & Methyl parathion & $298-00-0$ & 288 & 0 \\
\hline 39415 & Metolachlor & $51218-45-2$ & 303 & 215 \\
\hline 82630 & Metribuzin & 21087-64-9 & 303 & 60 \\
\hline 82671 & Molinate & $2212-67-1$ & 288 & 0 \\
\hline 49295 & 1-Naphthol & -- & 228 & 1 \\
\hline 82684 & Napropamide & $15299-99-7$ & 288 & 104 \\
\hline 49294 & Neburon & $555-37-3$ & 228 & 0 \\
\hline 49293 & Norflurazon & 27314-13-2 & 228 & 0 \\
\hline 49292 & Oryzalin & $19044-88-3$ & 228 & 3 \\
\hline 38866 & Oxamyl & $23135-22-0$ & 228 & 1 \\
\hline 39542 & Parathion & $56-38-2$ & 297 & 0 \\
\hline 82669 & Pebulate & $1114-71-2$ & 288 & 1 \\
\hline 82683 & Pendimethalin & $40487-42-1$ & 288 & 12 \\
\hline 82687 & cis-Permethrin & $52645-53-1$ & 288 & 2 \\
\hline 82664 & Phorate & $298-02-2$ & 288 & 0 \\
\hline 49291 & Picloram & $1918-02-1$ & 231 & 0 \\
\hline 04037 & Prometon & $1610-18-0$ & 303 & 56 \\
\hline 82676 & Pronamide & $23950-58-5$ & 289 & 35 \\
\hline 04024 & Propachlor & $1918-16-7$ & 288 & 11 \\
\hline 82679 & Propanil & $709-98-8$ & 288 & 5 \\
\hline 82685 & Propargite & $2312-35-8$ & 288 & 3 \\
\hline 49236 & Propham & $122-42-9$ & 228 & 0 \\
\hline 38538 & Propoxur & $114-26-1$ & 226 & 0 \\
\hline 04035 & Simazine & $122-34-9$ & 309 & 220 \\
\hline 39742 & $2,4,5-\mathrm{T}$ & $93-76-5$ & 252 & 2 \\
\hline 39740 & 2,4,5-T, unfiltered & $93-76-5$ & 59 & 17 \\
\hline 82670 & Tebuthiuron & $34014-18-1$ & 288 & 42 \\
\hline 82665 & Terbacil & $5902-51-2$ & 284 & 59 \\
\hline 82675 & Terbufos & 13071-79-9 & 288 & 0 \\
\hline 82681 & Thiobencarb & $28249-77-6$ & 288 & 0 \\
\hline 79747 & Total organic halide & -- & 92 & 76 \\
\hline 82678 & Triallate & $2303-17-5$ & 288 & 7 \\
\hline 49235 & Triclopyr & $55335-06-3$ & 231 & 16 \\
\hline 82661 & Trifluralin & $1582-09-8$ & 288 & 42 \\
\hline
\end{tabular}


Table 34. Concentrations of organic compounds detected in filtered water, lower Columbia River Basin, Oregon and Washington, 1994

[Only detectable concentrations are listed in this table; the term "filtered water" is an operational definition referring to the chemical analysis of that portion of a water-suspended sediment sample that passes through a nominal 0.70-micrometer filter; E, estimated value]

\begin{tabular}{|c|c|c|c|}
\hline Site name & \multirow[t]{2}{*}{ Date } & \multicolumn{2}{|c|}{ Concentration } \\
\hline \multicolumn{3}{|l|}{ Alachlor } & \\
\hline Willamette River at Portland, Oregon & $12-02-1994$ & 0.002 & $\mathrm{E}$ \\
\hline \multicolumn{4}{|l|}{ Atrazine } \\
\hline Columbia River at Warrendale, Oregon & 08-10-1994 & .002 & \\
\hline Columbia River at Warrendale, Oregon & 11-08-1994 & .006 & $\mathrm{E}$ \\
\hline Columbia River, river mile 102, downstream of Hayden Island, Oregon & 03-22-1994 & .003 & \\
\hline Columbia River, river mile 102, downstream of Hayden Island, Oregon & 07-25-1994 & .003 & \\
\hline Columbia River, river mile 102, downstream of Hayden Island, Oregon & $12-05-1994$ & .003 & $\mathrm{E}$ \\
\hline Columbia River near Columbia City, Oregon & 07-26-1994 & .004 & \\
\hline Columbia River near Columbia City, Oregon & 11-09-1994 & .020 & \\
\hline Columbia River at Beaver Army Terminal near Quincy, Oregon & 04-14-1994 & .032 & \\
\hline Columbia River at Beaver Army Terminal near Quincy, Oregon & 08-11-1994 & .004 & \\
\hline Willamette River at Portland, Oregon & 02-25-1994 & .160 & \\
\hline Willamette River at Portland, Oregon & 03-14-1994 & .037 & \\
\hline Willamette River at Portland, Oregon & 04-11-1994 & .170 & \\
\hline Willamette River at Portland, Oregon & 05-10-1994 & .020 & \\
\hline Willamette River at Portland, Oregon & 06-14-1994 & .012 & \\
\hline Willamette River at Portland, Oregon & 08-08-1994 & .010 & \\
\hline Willamette River at Portland, Oregon & 09-13-1994 & .013 & $\mathrm{E}$ \\
\hline Willamette River at Portland, Oregon & $10-29-1994$ & .029 & \\
\hline Willamette River at Portland, Oregon & 11-03-1994 & .130 & \\
\hline Willamette River at Portland, Oregon & 12-02-1994 & .180 & \\
\hline Multnomah Channel near mouth, at St. Helens, Oregon & 06-10-1994 & .011 & \\
\hline Multnomah Channel near mouth, at St. Helens, Oregon & 08-09-1994 & .008 & \\
\hline Multnomah Channel near mouth, at St. Helens, Oregon & 12-07-1994 & .160 & \\
\hline Lewis River at Woodland, Washington & 06-29-1994 & .003 & \\
\hline \multicolumn{4}{|l|}{ Carbaryl } \\
\hline Willamette River at Portland, Oregon & $02-25-1994$ & .017 & \\
\hline Willamette River at Portland, Oregon & 10-29-1994 & .006 & $\mathrm{E}$ \\
\hline \multicolumn{4}{|l|}{ Carbofuran } \\
\hline Willamette River at Portland, Oregon & $10-29-1994$ & .180 & $\mathrm{E}$ \\
\hline Willamette River at Portland, Oregon & 11-03-1994 & .088 & $\mathrm{E}$ \\
\hline \multicolumn{4}{|l|}{ Chlorpyrifos } \\
\hline Willamette River at Portland, Oregon & $12-02-1994$ & .006 & \\
\hline Lewis River at Woodland, Washington & 07-19-1994 & .010 & \\
\hline
\end{tabular}


Table 34. Concentrations of organic compounds detected in filtered water, lower Columbia River Basin, Oregon and Washington, 1994-Continued

[Only detectable concentrations are listed in this table; the term "filtered water" is an operational definition referring to the chemical analysis of that portion of a water-suspended sediment sample that passes through a nominal 0.70-micrometer filter; E, estimated value]

\begin{tabular}{|c|c|c|c|}
\hline Site name & Date & \multicolumn{2}{|c|}{ Concentration } \\
\hline \multicolumn{4}{|c|}{ Dacthal; Chlorthal-dimethyl (DCPA) } \\
\hline Columbia River at Warrendale, Oregon & 06-15-1994 & 0.001 & \\
\hline Columbia River at Warrendale, Oregon & 11-08-1994 & .003 & $\mathrm{E}$ \\
\hline Columbia River, river mile 102, downstream of Hayden Island, Oregon & 12-05-1994 & .001 & $\mathrm{E}$ \\
\hline Columbia River near Columbia City, Oregon & 11-09-1994 & .003 & $\mathrm{E}$ \\
\hline Columbia River at Beaver Army Terminal near Quincy, Oregon & 08-11-1994 & .002 & \\
\hline Willamette River at Portland, Oregon & 10-29-1994 & .004 & \\
\hline Willamette River at Portland, Oregon & 12-02-1994 & .001 & $\mathrm{E}$ \\
\hline \multicolumn{4}{|l|}{ Deethylatrazine } \\
\hline Columbia River at Beaver Army Terminal near Quincy, Oregon & 04-14-1994 & .003 & \\
\hline Willamette River at Portland, Oregon & 02-25-1994 & .026 & \\
\hline Willamette River at Portland, Oregon & 04-11-1994 & .010 & \\
\hline Willamette River at Portland, Oregon & 05-10-1994 & .005 & \\
\hline Willamette River at Portland, Oregon & $10-29-1994$ & .004 & $\mathrm{E}$ \\
\hline Willamette River at Portland, Oregon & 11-03-1994 & .004 & $\mathrm{E}$ \\
\hline Willamette River at Portland, Oregon & 12-02-1994 & .006 & $\mathrm{E}$ \\
\hline Multnomah Channel near mouth, at St. Helens, Oregon & 06-10-1994 & .006 & \\
\hline Multnomah Channel near mouth, at St. Helens, Oregon & 12-07-1994 & .009 & $\mathrm{E}$ \\
\hline \multicolumn{4}{|l|}{ Diazinon } \\
\hline Willamette River at Portland, Oregon & 05-10-1994 & .006 & \\
\hline Willamette River at Portland, Oregon & 06-14-1994 & .009 & \\
\hline Willamette River at Portland, Oregon & 08-08-1994 & .007 & \\
\hline Willamette River at Portland, Oregon & 09-13-1994 & .008 & $\mathrm{E}$ \\
\hline Willamette River at Portland, Oregon & $10-29-1994$ & .006 & $\mathrm{E}$ \\
\hline Multnomah Channel near mouth, at St. Helens, Oregon & 06-10-1994 & .006 & \\
\hline Multnomah Channel near mouth, at St. Helens, Oregon & 08-09-1994 & .005 & \\
\hline \multicolumn{4}{|l|}{ Eptam (EPTC) } \\
\hline Columbia River at Warrendale, Oregon & 05-11-1994 & .006 & \\
\hline Columbia River at Warrendale, Oregon & 06-15-1994 & .003 & \\
\hline Columbia River, river mile 102, downstream of Hayden Island, Oregon & 03-22-1994 & .002 & \\
\hline Columbia River, river mile 102, downstream of Hayden Island, Oregon & $05-25-1994$ & .004 & \\
\hline Columbia River near Columbia City, Oregon & 05-09-1994 & .005 & \\
\hline Willamette River at Portland, Oregon & 05-10-1994 & .005 & \\
\hline Willamette River at Portland, Oregon & 06-14-1994 & .005 & \\
\hline Willamette River at Portland, Oregon & 12-02-1994 & .004 & $\mathrm{E}$ \\
\hline Multnomah Channel near mouth, at St. Helens, Oregon & 06-10-1994 & .006 & \\
\hline
\end{tabular}


Table 34. Concentrations of organic compounds detected in filtered water, lower Columbia River Basin, Oregon and Washington, 1994-Continued

[Only detectable concentrations are listed in this table; the term "filtered water" is an operational definition referring to the chemical analysis of that portion of a water-suspended sediment sample that passes through a nominal 0.70-micrometer filter; E, estimated value]

\begin{tabular}{|c|c|c|c|}
\hline Site name & Date & \multicolumn{2}{|c|}{ Concentration } \\
\hline \multicolumn{4}{|l|}{ Ethoprop } \\
\hline Willamette River at Portland, Oregon & $10-29-1994$ & 0.015 & \\
\hline Willamette River at Portland, Oregon & 11-03-1994 & .023 & \\
\hline Willamette River at Portland, Oregon & 12-02-1994 & .005 & $\mathrm{E}$ \\
\hline \multicolumn{4}{|l|}{ Fonofos } \\
\hline Willamette River at Portland, Oregon & 04-11-1994 & .010 & \\
\hline Willamette River at Portland, Oregon & $10-25-1994$ & .002 & $\mathrm{E}$ \\
\hline Willamette River at Portland, Oregon & 11-03-1994 & .005 & $\mathrm{E}$ \\
\hline Willamette River at Portland, Oregon & 12-02-1994 & .005 & $\mathrm{E}$ \\
\hline \multicolumn{4}{|l|}{ Metolachlor } \\
\hline Columbia River at Warrendale, Oregon & 11-08-1994 & .004 & $\mathrm{E}$ \\
\hline Columbia River, river mile 102, downstream of Hayden Island, Oregon & $12-05-1994$ & .002 & $\mathrm{E}$ \\
\hline Columbia River near Columbia City, Oregon & 11-09-1994 & .017 & \\
\hline Columbia River at Beaver Army Terminal near Quincy, Oregon & 04-14-1994 & .002 & \\
\hline Columbia River at Beaver Army Terminal near Quincy, Oregon & 08-11-1994 & .003 & \\
\hline Willamette River at Portland, Oregon & 02-25-1994 & .016 & \\
\hline Willamette River at Portland, Oregon & 03-14-1994 & .006 & \\
\hline Willamette River at Portland, Oregon & 04-11-1994 & .008 & \\
\hline Willamette River at Portland, Oregon & 05-10-1994 & .005 & \\
\hline Willamette River at Portland, Oregon & 06-14-1994 & .004 & \\
\hline Willamette River at Portland, Oregon & 09-13-1994 & .003 & $\mathrm{E}$ \\
\hline Willamette River at Portland, Oregon & $10-29-1994$ & .049 & \\
\hline Willamette River at Portland, Oregon & 11-03-1994 & .110 & \\
\hline Willamette River at Portland, Oregon & 12-02-1994 & .048 & \\
\hline Multnomah Channel near mouth, at St. Helens, Oregon & 06-10-1994 & .004 & \\
\hline Multnomah Channel near mouth, at St. Helens, Oregon & 10-26-1994 & .008 & $\mathrm{E}$ \\
\hline Multnomah Channel near mouth, at St. Helens, Oregon & 12-07-1994 & .044 & \\
\hline \multicolumn{4}{|l|}{ Metribuzin } \\
\hline Willamette River at Portland, Oregon & $02-25-1994$ & .029 & \\
\hline Willamette River at Portland, Oregon & 12-02-1994 & .020 & \\
\hline Multnomah Channel near mouth, at St. Helens, Oregon & 12-07-1994 & .021 & \\
\hline \multicolumn{4}{|l|}{ Napropamide } \\
\hline Columbia River, river mile 102, downstream of Hayden Island, Oregon & $12-05-1994$ & .007 & $\mathrm{E}$ \\
\hline Willamette River at Portland, Oregon & 02-25-1994 & .068 & \\
\hline Willamette River at Portland, Oregon & 10-29-1994 & .022 & \\
\hline Willamette River at Portland, Oregon & 11-03-1994 & .029 & \\
\hline Willamette River at Portland, Oregon & 12-02-1994 & .006 & $\mathrm{E}$ \\
\hline
\end{tabular}


Table 34. Concentrations of organic compounds detected in filtered water, lower Columbia River Basin, Oregon and Washington, 1994-Continued

[Only detectable concentrations are listed in this table; the term "filtered water" is an operational definition referring to the chemical analysis of that portion of a water-suspended sediment sample that passes through a nominal 0.70 -micrometer filter; E, estimated value]

\begin{tabular}{|c|c|c|c|}
\hline Site name & Date & \multicolumn{2}{|c|}{ Concentration } \\
\hline \multicolumn{4}{|l|}{ Prometon } \\
\hline Willamette River at Portland, Oregon & 08-08-1994 & 0.003 & \\
\hline \multicolumn{4}{|l|}{ Pronamide } \\
\hline Willamette River at Portland, Oregon & $02-25-1994$ & .030 & \\
\hline Willamette River at Portland, Oregon & 12-02-1994 & .018 & \\
\hline \multicolumn{4}{|l|}{ Simazine } \\
\hline Columbia River at Warrendale, Oregon & 08-10-1994 & .001 & \\
\hline Columbia River near Columbia City, Oregon & 11-09-1994 & .009 & \\
\hline Columbia River at Beaver Army Terminal near Quincy, Oregon & 04-14-1994 & .011 & \\
\hline Willamette River at Portland, Oregon & 02-25-1994 & .064 & \\
\hline Willamette River at Portland, Oregon & 03-14-1994 & .013 & \\
\hline Willamette River at Portland, Oregon & 04-11-1994 & .049 & \\
\hline Willamette River at Portland, Oregon & 05-10-1994 & .010 & \\
\hline Willamette River at Portland, Oregon & 06-14-1994 & .016 & \\
\hline Willamette River at Portland, Oregon & 08-08-1994 & .005 & \\
\hline Willamette River at Portland, Oregon & 09-13-1994 & .008 & \\
\hline Willamette River at Portland, Oregon & 10-29-1994 & .066 & \\
\hline Willamette River at Portland, Oregon & 11-03-1994 & .073 & \\
\hline Willamette River at Portland, Oregon & 12-02-1994 & .043 & \\
\hline Multnomah Channel near mouth, at St. Helens, Oregon & 06-10-1994 & .019 & \\
\hline Multnomah Channel near mouth, at St. Helens, Oregon & 08-09-1994 & .004 & \\
\hline Multnomah Channel near mouth, at St. Helens, Oregon & 12-07-1994 & .035 & \\
\hline \multicolumn{4}{|l|}{ Tebuthiuron } \\
\hline Willamette River at Portland, Oregon & $02-25-1994$ & .006 & \\
\hline Willamette River at Portland, Oregon & $10-29-1994$ & .007 & $\mathrm{E}$ \\
\hline Willamette River at Portland, Oregon & $12-02-1994$ & .003 & $\mathrm{E}$ \\
\hline \multicolumn{4}{|l|}{ Terbacil } \\
\hline Willamette River at Portland, Oregon & $02-25-1994$ & .032 & \\
\hline Willamette River at Portland, Oregon & 04-11-1994 & .080 & \\
\hline Willamette River at Portland, Oregon & $10-29-1994$ & .017 & $\mathrm{E}$ \\
\hline Willamette River at Portland, Oregon & 11-03-1994 & .027 & $\mathrm{E}$ \\
\hline Willamette River at Portland, Oregon & $12-02-1994$ & .010 & $\mathrm{E}$ \\
\hline Multnomah Channel near mouth, at St. Helens, Oregon & 06-10-1994 & .012 & \\
\hline Multnomah Channel near mouth, at St. Helens, Oregon & $12-07-1994$ & .008 & $\mathrm{E}$ \\
\hline \multicolumn{4}{|l|}{ Triallate } \\
\hline Willamette River at Portland, Oregon & $02-25-1994$ & .004 & \\
\hline Willamette River at Portland, Oregon & $12-02-1994$ & .008 & $\mathrm{E}$ \\
\hline
\end{tabular}


Table 35. Chemical classifications for organic compounds analyzed, lower Columbia River Basin, Oregon and Washington, 1994

[--, no trade name; *, metabolite or pesticide no longer registered for use; see table 9 for Chemical Abstracts Services registry numbers]

\begin{tabular}{|c|c|c|c|}
\hline Common Name & Trade name & Application & Class \\
\hline $\begin{array}{l}\text { acetochlor } \\
\text { alachlor } \\
\text { atrazine } \\
\text { azinphos-methyl } \\
\text { benfluralin }\end{array}$ & $\begin{array}{c}\text { Acenit; Elbacet; Harness; Mon-097 } \\
\text { Lasso } \\
\text { AAtrex } \\
\text { Guthion } \\
\text { Benefin; Balan; Bonalan }\end{array}$ & $\begin{array}{l}\text { herbicide } \\
\text { herbicide } \\
\text { herbicide } \\
\text { insecticide } \\
\text { herbicide }\end{array}$ & $\begin{array}{l}\text { chloroacetamide } \\
\text { chloroacetamide } \\
\text { triazine } \\
\text { organophosphate } \\
\text { dinitroaniline }\end{array}$ \\
\hline $\begin{array}{l}\text { butylate } \\
\text { carbaryl } \\
\text { carbofuran } \\
\text { chlorpyrifos } \\
\text { cyanazine }\end{array}$ & $\begin{array}{l}\text { Genate plus; Suntan }+ \\
\text { Sevin } \\
\text { Furandan } \\
\text { Dursban } \\
--\end{array}$ & $\begin{array}{l}\text { herbicide } \\
\text { insecticide } \\
\text { insecticide } \\
\text { insecticide } \\
\text { herbicide }\end{array}$ & $\begin{array}{l}\text { dinitroaniline } \\
\text { carbamate } \\
\text { carbamate } \\
\text { organophosphate } \\
\text { triazine }\end{array}$ \\
\hline $\begin{array}{l}\text { DCPA } \\
\text { 4,4'-DDE } \\
\text { deethylatrazine } \\
\text { diazinon } \\
\text { dieldrin }\end{array}$ & $\begin{array}{c}\text { Dacthal; Chlorthal-dimethyl } \\
-- \\
-- \\
\text {-- } \\
\text { Panoram D-31 }\end{array}$ & $\begin{array}{l}\text { herbicide } \\
\text { insecticide } \\
\qquad * \\
\text { insecticide } \\
\text { insecticide }\end{array}$ & $\begin{array}{l}\text { organochlorine } \\
\text { organochlorine } \\
\text { metabolite } \\
\text { organophosphate } \\
\text { organochlorine }\end{array}$ \\
\hline $\begin{array}{l}\text { 2,6-diethylaniline } \\
\text { disulfoton } \\
\text { EPTC } \\
\text { ethalfluralin } \\
\text { ethoprop }\end{array}$ & $\begin{array}{c}-- \\
-- \\
\text { Eptam } \\
\text { Sonalan } \\
\text { Mocap; Ethoprophos }\end{array}$ & $\begin{array}{l}* * \\
\text { insecticide } \\
\text { herbicide } \\
\text { herbicide } \\
\text { insecticide }\end{array}$ & $\begin{array}{c}\text { metabolite } \\
\text { organophosphate } \\
\text { carbamate } \\
\text { dinitroaniline } \\
\text { organophosphate }\end{array}$ \\
\hline $\begin{array}{l}\text { fonofos } \\
\text { alpha-HCH } \\
\text { gamma-HCH } \\
\text { linuron } \\
\text { malathion }\end{array}$ & $\begin{array}{l}\text { Dyfonate } \\
\text { alpha-BHC } \\
\text { Lindane } \\
\text { Lorox; Linex } \\
\text {-- }\end{array}$ & $\begin{array}{l}\text { insecticide } \\
\text { insecticide } \\
\text { insecticide } \\
\text { herbicide } \\
\text { insecticide }\end{array}$ & $\begin{array}{l}\text { organophosphate } \\
\text { organochlorine } \\
\text { organochlorine } \\
\text { phenyl urea } \\
\text { organophosphate }\end{array}$ \\
\hline $\begin{array}{l}\text { metolachlor } \\
\text { methyl parathion } \\
\text { metribuzin } \\
\text { molinate } \\
\text { napropamide }\end{array}$ & $\begin{array}{c}\text { Dual } \\
\text { Denncap-M } \\
\text { Lexone; Sencor } \\
\text { Ordram } \\
\text { Devrinol }\end{array}$ & $\begin{array}{l}\text { herbicide } \\
\text { insecticide } \\
\text { herbicide } \\
\text { herbicide } \\
\text { herbicide }\end{array}$ & $\begin{array}{c}\text { chloroacetamide } \\
\text { organophosphate } \\
\text { triazine } \\
\text { carbamate } \\
\text { chloroacetamide }\end{array}$ \\
\hline $\begin{array}{l}\text { parathion } \\
\text { pebulate } \\
\text { pendimethilan } \\
\text { cis-permethrin } \\
\text { phorate }\end{array}$ & $\begin{array}{c}\text {-- } \\
\text { Tillam } \\
\text { Prowl; Stomp } \\
\text { Pounce; Ambush } \\
\text { Thimet }\end{array}$ & $\begin{array}{l}\text { insecticide } \\
\text { herbicide } \\
\text { herbicide } \\
\text { insecticide } \\
\text { insecticide }\end{array}$ & $\begin{array}{c}\text { organophosphate } \\
\text { carbamate } \\
\text { dinitroaniline } \\
\text { permethrin } \\
\text { organophosphate }\end{array}$ \\
\hline $\begin{array}{l}\text { prometon } \\
\text { pronamide } \\
\text { propachlor } \\
\text { propanil } \\
\text { propargite }\end{array}$ & $\begin{array}{c}\text { Pramitol } \\
\text { Kerb, Propyzamid } \\
\text { Ramrod } \\
\text { Stampede } \\
\text { Omite, Alkyl sulfite }\end{array}$ & $\begin{array}{l}\text { herbicide } \\
\text { herbicide } \\
\text { herbicide } \\
\text { herbicide } \\
\text { insecticide }\end{array}$ & $\begin{array}{c}\text { triazine } \\
\text { chloroacetamide } \\
\text { chloroacetamide } \\
\text { chloroacetamide } \\
\text { miscellaneous }\end{array}$ \\
\hline $\begin{array}{l}\text { simazine } \\
\text { tebuthiuron } \\
\text { terbacil } \\
\text { terbufos } \\
\text { thiobencarb }\end{array}$ & $\begin{array}{c}\text { Aquazine, Princep } \\
\text { Spike } \\
\text { Sinbar } \\
\text { Counter } \\
\text { Bolero }\end{array}$ & $\begin{array}{l}\text { herbicide } \\
\text { herbicide } \\
\text { herbicide } \\
\text { insecticide } \\
\text { herbicide }\end{array}$ & $\begin{array}{c}\text { triazine } \\
\text { phenyl urea } \\
\text { uracil } \\
\text { organophosphate } \\
\text { carbamate }\end{array}$ \\
\hline $\begin{array}{l}\text { triallate } \\
\text { trifluralin }\end{array}$ & $\begin{array}{c}\text { Avadex bw, Far-go } \\
\text { Treflan }\end{array}$ & $\begin{array}{l}\text { herbicide } \\
\text { herbicide }\end{array}$ & $\begin{array}{c}\text { carbamate } \\
\text { dinitroaniline }\end{array}$ \\
\hline
\end{tabular}




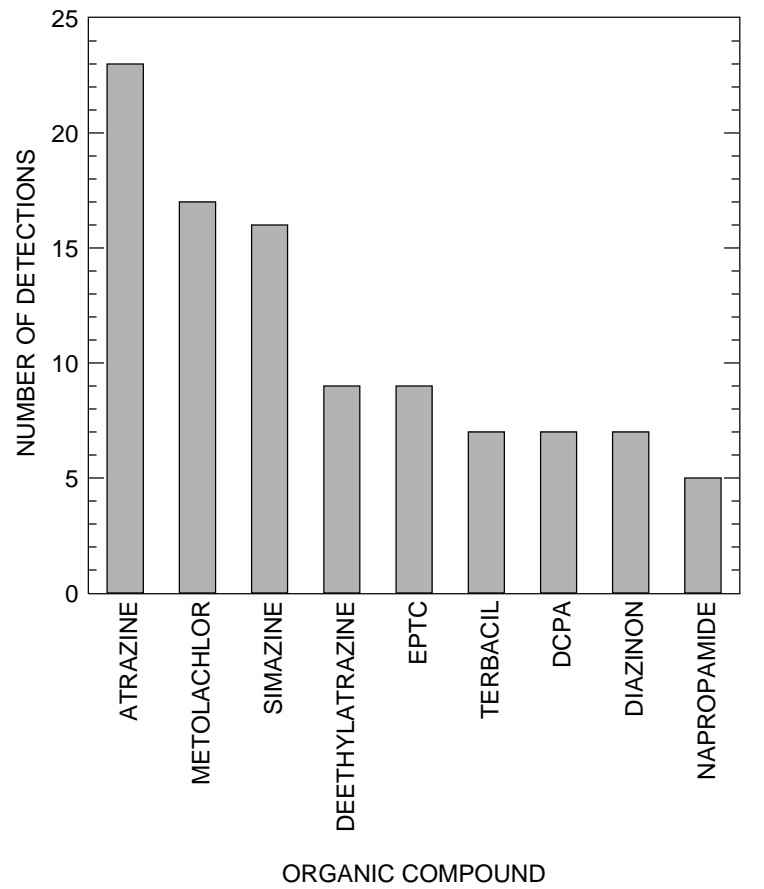

Figure 33. Frequently detected organic compounds, lower Columbia River Basin, Oregon and Washington, 1994. (Numbers are based on total of 45 samples.)

Atrazine, metolachlor, and simazine, were detected in 93, 86, and 93 percent, respectively, of the samples collected in the Willamette River and Multnomah Channel (fig. 34). Additionally, all of the frequently detected pesticides shown in figure 33 - except for DCPA-were detected more often in the Willamette River and Multnomah Channel, than at the other main-stem and tributary sites in the lower Columbia River Basin. The high percentage of detections of agricultural organic compounds from the Willamette River Basin reflects the fact that most of the lower Columbia River Basin's agricultural land is in the Willamette Basin (table 2).

Although not detected as frequently as the before-mentioned organic compounds, EPTC $\left(\right.$ eptam $\left.^{6}\right)$ was detected in the lower Columbia River Basin shortly after the spring-application period. It was detected consistently from March to June 1994 in concentrations ranging from 0.002 to $0.006 \mu \mathrm{g} / \mathrm{L}$ in the main stem at Warrendale, Hayden Island, and Columbia City, and in the Willamette River and

\footnotetext{
${ }^{6}$ EPTC, a selective carbamate herbicide that decomposes in 4 to 6 weeks, has been used as a preplant soil treatment to inhibit the growth of weed seedlings (Burrill and others, 1992).
}

Multnomah Channel tributaries. EPTC was introduced in the lower Columbia River Basin in the early 1960 s and is used to treat a variety of crops, including beans, peas, sugar-beet root, clover, and strawberries. It was used through the time of this study (John Rinehold, Oregon State University, oral commun., 1994).

The Willamette River, which is a source of atrazine to the lower Columbia River, has higher atrazine concentrations during the spring and fall high-streamflow periods than during the summer low-streamflow period (fig. 35). High atrazine concentrations associated with spring runoff coincide with periods of application. Atrazine is used for preemergent-weed control in preparation for grain crops and nursery stock and is normally applied in March and April when soil moisture is high and before winter rains cease (Burrill and others, 1992). In the Willamette River Basin alone, $382,000 \mathrm{lbs}$ of atrazine were applied in 1987; in contrast, only 4,500 lbs were applied in the Clatskanie River drainage (John Rinehold, Oregon State University, unpub. data, 1993). The higher atrazine concentrations measured in November and December coincide with high suspended-sediment concentrations. These higher atrazine concentrations probably result from the presence of soil-sorbed atrazine that was flushed from freshly eroded agricultural soils that enter the stream during fall runoff.

Most likely, however, these higher concentrations during fall runoff were not transported in the suspended phase. Instead, equilibrium calculations show that atrazine in the Willamette River at Portland, during fall and winter runoff, is predominantly in the filtered-water (dissolved) phase. Using a suspended organic carbon-water sorption coefficient $\left(K_{o c}\right)$ of 163 (Mercer and others, 1990), and data from the November 3, 1994 sampling in the Willamette River, the fraction of atrazine transported in the suspended form can be calculated from the following equations. The $K_{o c}$ is related to the sorption coefficient $(\mathrm{Kd})$ by:

$$
K_{o c}=K_{d} / f_{o c}
$$

where $f_{o c}$ is the organic carbon fraction in the suspended sediment and $K_{d}$ is defined as 
Table 36. Distribution of organic-compound concentrations in filtered water, lower Columbia River Basin, Oregon and Washington, 1994

[The term "filtered water" is an operational definition referring to the chemical analysis of that portion of a water-suspended sediment sample that passes through a nominal 0.70-micrometer filter; to avoid statistical bias that may be associated with constituents analyzed more than once at a site, only one element concentration per month was statistically summarized; concentrations are reported in micrograms per liter; acetochlor, azinphos-methyl, benfluralin, butylate, cyanazine, 4,4'-DDE, dieldrin, 2,6-diethylaniline, dimethoate, disulfoton, ethalfluralin, alpha-HCH, gamma-HCH (lindane), linuron, malathion, methyl parathion, molinate, parathion, pebulate, pendimethalin, cis-permethrin, phorate, propachlor, propanil, propargite, tebuthiuron, terbufos, thiobencarb, and trifluralin are not included in this table, because no samples had concentrations greater than their corresponding method detection limit; see table 9 for Chemical Abstracts Services registry numbers and method detection limits; see table 7 for full site names; -- indicates fewer than 6 samples were collected, therefore the percentile was not calculated; <, less than]

\begin{tabular}{|c|c|c|c|c|c|c|c|c|}
\hline \multirow{2}{*}{ Site name } & \multirow{2}{*}{$\begin{array}{c}\text { Number } \\
\text { of } \\
\text { samples }\end{array}$} & \multirow{2}{*}{$\begin{array}{l}\text { Minimum } \\
\text { value }\end{array}$} & \multicolumn{5}{|c|}{ Value at indicated percentile } & \multirow{2}{*}{$\begin{array}{l}\text { Maximum } \\
\text { value }\end{array}$} \\
\hline & & & 10 & 25 & 50 & 75 & 90 & \\
\hline \multicolumn{9}{|c|}{ Alachlor } \\
\hline Warrendale & 4 & $<0.002$ & -- & -- & $<0.002$ & -- & -- & $<0.002$ \\
\hline Hayden Island & 4 & $<.002$ & -- & -- & $<.002$ & -- & -- & $<.002$ \\
\hline Columbia City & 4 & $<.002$ & -- & -- & $<.002$ & -- & -- & $<.002$ \\
\hline Beaver & 4 & $<.002$ & -- & -- & $<.002$ & -- & -- & $<.002$ \\
\hline Willamette River & 10 & $<.002$ & $<.002$ & $<.002$ & $<.002$ & $<.002$ & $<.002$ & .002 \\
\hline Multnomah Channel & 4 & $<.002$ & -- & -- & $<.002$ & -- & -- & $<.002$ \\
\hline Sandy River & 3 & $<.002$ & -- & -- & $<.002$ & -- & -- & $<.002$ \\
\hline Lewis River & 4 & $<.002$ & -- & -- & $<.002$ & -- & -- & $<.002$ \\
\hline Kalama River & 4 & $<.002$ & -- & -- & $<.002$ & -- & -- & $<.002$ \\
\hline Cowlitz River & 4 & $<.002$ & -- & -- & $<.002$ & -- & -- & $<.002$ \\
\hline$\overline{\text { All sites }}$ & 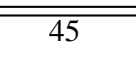 & $\overline{<<.002}$ & $\overline{c<.002}$ & $\overline{c<.002}$ & $\overline{c<.002}$ & $\overline{c<.002}$ & $\overline{c<.002}$ & 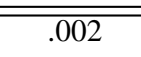 \\
\hline \multicolumn{9}{|c|}{ Atrazine } \\
\hline Warrendale & 4 & $<.001$ & -- & -- & .001 & -- & -- & .006 \\
\hline Hayden Island & 4 & $<.001$ & -- & -- & .003 & -- & -- & .003 \\
\hline Columbia City & 4 & $<.001$ & -- & -- & .002 & -- & -- & .020 \\
\hline Beaver & 4 & $<.001$ & -- & -- & .002 & -- & -- & .032 \\
\hline Willamette River & 10 & .010 & .010 & .013 & .033 & .162 & .179 & .180 \\
\hline Multnomah Channel & 4 & $<.001$ & -- & -- & .010 & -- & -- & .160 \\
\hline Sandy River & 3 & $<.001$ & -- & -- & $<.001$ & -- & -- & $<.001$ \\
\hline Lewis River & 4 & $<.001$ & -- & -- & $<.001$ & -- & -- & .003 \\
\hline Kalama River & 4 & $<.001$ & -- & -- & $<.001$ & -- & -- & $<.001$ \\
\hline Cowlitz River & 4 & $<.001$ & -- & -- & $<.001$ & -- & -- & $<.001$ \\
\hline All sites & $\overline{45}$ & $\overline{<<.001}$ & $\overline{c<.001}$ & 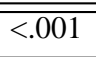 & .002 & 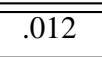 & .142 & .180 \\
\hline \multicolumn{9}{|c|}{ Carbaryl } \\
\hline Warrendale & 4 & $<.003$ & -- & -- & $<.003$ & -- & -- & $<.003$ \\
\hline Hayden Island & 4 & $<.003$ & -- & -- & $<.003$ & -- & -- & $<.003$ \\
\hline Columbia City & 4 & $<.003$ & -- & -- & $<.003$ & -- & -- & $<.003$ \\
\hline Beaver & 4 & $<.003$ & -- & -- & $<.003$ & -- & -- & $<.003$ \\
\hline Willamette River & 10 & $<.003$ & $<.003$ & $<.003$ & $<.003$ & $<.003$ & .016 & 0.017 \\
\hline Multnomah Channel & 4 & $<.003$ & -- & -- & $<.003$ & -- & -- & $<.003$ \\
\hline Sandy River & 3 & $<.003$ & -- & -- & $<.003$ & -- & -- & $<.003$ \\
\hline
\end{tabular}


Table 36. Distribution of organic-compound concentrations in filtered water, lower Columbia River Basin, Oregon and Washington, 1994-Continued

[The term "filtered water" is an operational definition referring to the chemical analysis of that portion of a water-suspended sediment sample that passes through a nominal 0.70-micrometer filter; to avoid statistical bias that may be associated with constituents analyzed more than once at a site, only one element concentration per month was statistically summarized; concentrations are reported in micrograms per liter; acetochlor, azinphos-methyl, benfluralin, butylate, cyanazine, 4,4'-DDE, dieldrin, 2,6-diethylaniline, dimethoate, disulfoton, ethalfluralin, alpha- $\mathrm{HCH}$, gamma- $\mathrm{HCH}$ (lindane), linuron, malathion, methyl parathion, molinate, parathion, pebulate, pendimethalin, cis-permethrin, phorate, propachlor, propanil, propargite, tebuthiuron, terbufos, thiobencarb, and trifluralin are not included in this table, because no samples had concentrations greater than their corresponding method detection limit; see table 9 for Chemical Abstracts Services registry numbers and method detection limits; see table 7 for full site names; -- indicates fewer than 6 samples were collected, therefore the percentile was not calculated; <, less than]

\begin{tabular}{|c|c|c|c|c|c|c|c|c|}
\hline \multirow{2}{*}{ Site name } & \multirow{2}{*}{$\begin{array}{c}\text { Number } \\
\text { of } \\
\text { samples }\end{array}$} & \multirow{2}{*}{$\begin{array}{l}\text { Minimum } \\
\text { value }\end{array}$} & \multicolumn{5}{|c|}{ Value at indicated percentile } & \multirow{2}{*}{$\begin{array}{l}\text { Maximum } \\
\text { value }\end{array}$} \\
\hline & & & 10 & 25 & 50 & 75 & 90 & \\
\hline \multicolumn{9}{|c|}{ Carbaryl-Continued } \\
\hline Lewis River & 4 & $<0.003$ & -- & -- & $<0.003$ & -- & -- & $<0.003$ \\
\hline Kalama River & 4 & $<.003$ & -- & -- & $<.003$ & -- & -- & $<.003$ \\
\hline Cowlitz River & 4 & $<.003$ & -- & -- & $<.003$ & -- & -- & $<.003$ \\
\hline All sites & $\overline{45}$ & $<<.003$ & $\overline{<0.003}$ & $\overline{<<0.003}$ & $<<.003$ & $\overline{<<0.003}$ & $\overline{<0.003}$ & $\overline{0.017}$ \\
\hline \multicolumn{9}{|c|}{ Carbofuran } \\
\hline Warrendale & 4 & $<.003$ & -- & -- & $<.003$ & -- & -- & $<.003$ \\
\hline Hayden Island & 4 & $<.003$ & -- & -- & $<.003$ & -- & -- & $<.003$ \\
\hline Columbia City & 4 & $<.003$ & -- & -- & $<.003$ & -- & -- & $<.003$ \\
\hline Beaver & 4 & $<.003$ & -- & -- & $<.003$ & -- & -- & $<.003$ \\
\hline Willamette River & 10 & $<.003$ & $<.003$ & $<.003$ & $<.003$ & .023 & .171 & .180 \\
\hline Multnomah Channel & 4 & $<.003$ & -- & -- & $<.003$ & -- & -- & $<.003$ \\
\hline Sandy River & 3 & $<.003$ & -- & -- & $<.003$ & -- & -- & $<.003$ \\
\hline Lewis River & 4 & $<.003$ & -- & -- & $<.003$ & -- & -- & $<.003$ \\
\hline Kalama River & 4 & $<.003$ & -- & -- & $<.003$ & -- & -- & $<.003$ \\
\hline Cowlitz River & 4 & $<.003$ & -- & -- & $<.003$ & -- & -- & $<.003$ \\
\hline All sites & 45 & $<<.003$ & $<<.003$ & $<<.003$ & $<<.003$ & $<<.003$ & $<<.003$ & .180 \\
\hline \multicolumn{9}{|c|}{ Chlorpyrifos } \\
\hline Warrendale & 4 & $<.004$ & $\begin{array}{ll}- \\
-\end{array}$ & -- & $<.004$ & -- & -- & $<.004$ \\
\hline Hayden Island & 4 & $<.004$ & -- & -- & $<.004$ & -- & -- & $<.004$ \\
\hline Columbia City & 4 & $<.004$ & -- & -- & $<.004$ & -- & -- & $<.004$ \\
\hline Beaver & 4 & $<.004$ & -- & -- & $<.004$ & -- & -- & $<.004$ \\
\hline Willamette River & 10 & $<.004$ & $<.004$ & $<.004$ & $<.004$ & $<.004$ & .006 & .006 \\
\hline Multnomah Channel & 4 & $<.004$ & -- & -- & $<.004$ & -- & -- & $<.004$ \\
\hline Sandy River & 3 & $<.004$ & -- & -- & $<.004$ & -- & -- & $<.004$ \\
\hline Lewis River & 4 & $<.004$ & -- & -- & $<.004$ & -- & -- & .010 \\
\hline Kalama River & 4 & $<.004$ & -- & -- & $<.004$ & -- & -- & $<.004$ \\
\hline Cowlitz River & 4 & $<.004$ & -- & -- & $<.004$ & -- & -- & $<.004$ \\
\hline All sites & 45 & $<<.004$ & $<<.004$ & $<<.004$ & $<<.004$ & $<<.004$ & $<.004$ & .010 \\
\hline \multicolumn{9}{|c|}{ Dacthal; Chlorthal-dimethyl (DCPA) } \\
\hline Warrendale & 4 & $<.002$ & -- & -- & $<.002$ & -- & -- & .003 \\
\hline Hayden Island & 4 & $<.002$ & -- & -- & $<.002$ & -- & -- & $<.002$ \\
\hline Columbia City & 4 & $<.002$ & -- & -- & $<.002$ & -- & -- & .003 \\
\hline Beaver & 4 & $<.002$ & -- & -- & $<.002$ & -- & -- & .002 \\
\hline
\end{tabular}


Table 36. Distribution of organic-compound concentrations in filtered water, lower Columbia River Basin, Oregon and Washington, 1994-Continued

[The term "filtered water" is an operational definition referring to the chemical analysis of that portion of a water-suspended sediment sample that passes through a nominal 0.70-micrometer filter; to avoid statistical bias that may be associated with constituents analyzed more than once at a site, only one element concentration per month was statistically summarized; concentrations are reported in micrograms per liter; acetochlor, azinphos-methyl, benfluralin, butylate, cyanazine, 4,4'-DDE, dieldrin, 2,6-diethylaniline, dimethoate, disulfoton, ethalfluralin, alpha- $\mathrm{HCH}$, gamma- $\mathrm{HCH}$ (lindane), linuron, malathion, methyl parathion, molinate, parathion, pebulate, pendimethalin, cis-permethrin, phorate, propachlor, propanil, propargite, tebuthiuron, terbufos, thiobencarb, and trifluralin are not included in this table, because no samples had concentrations greater than their corresponding method detection limit; see table 9 for Chemical Abstracts Services registry numbers and method detection limits; see table 7 for full site names; -- indicates fewer than 6 samples were collected, therefore the percentile was not calculated; <, less than]

\begin{tabular}{|c|c|c|c|c|c|c|c|c|}
\hline \multirow{2}{*}{ Site name } & \multirow{2}{*}{$\begin{array}{l}\text { Number } \\
\text { of } \\
\text { samples }\end{array}$} & \multirow{2}{*}{$\begin{array}{l}\text { Minimum } \\
\text { value }\end{array}$} & \multicolumn{5}{|c|}{ Value at indicated percentile } & \multirow{2}{*}{$\begin{array}{l}\text { Maximum } \\
\text { value }\end{array}$} \\
\hline & & & 10 & 25 & 50 & 75 & 90 & \\
\hline \multicolumn{9}{|c|}{ Dacthal; Chlorthal-dimethyl (DCPA)—Continued } \\
\hline Willamette River & 10 & $<0.002$ & $<0.002$ & $<0.002$ & $<0.002$ & $<0.002$ & 0.004 & 0.004 \\
\hline Multnomah Channel & 4 & $<.002$ & -- & -- & $<.002$ & -- & -- & $<.002$ \\
\hline Sandy River & 3 & $<.002$ & -- & -- & $<.002$ & -- & -- & $<.002$ \\
\hline Lewis River & 4 & $<.002$ & -- & -- & $<.002$ & -- & -- & $<.002$ \\
\hline Kalama River & 4 & $<.002$ & -- & -- & $<.002$ & -- & -- & $<.002$ \\
\hline Cowlitz River & 4 & $<.002$ & -- & -- & $<.002$ & -- & -- & $<.002$ \\
\hline All sites & 45 & $<.002$ & $<.002$ & $<.002$ & $<.002$ & $<.002$ & $<.002$ & .004 \\
\hline \multicolumn{9}{|c|}{ Deethylatrazine } \\
\hline Warrendale & 4 & $<.002$ & -- & -- & $<.002$ & -- & -- & $<.002$ \\
\hline Hayden Island & 4 & $<.002$ & -- & -- & $<.002$ & -- & -- & $<.002$ \\
\hline Columbia City & 4 & $<.002$ & -- & -- & $<.002$ & -- & -- & $<.002$ \\
\hline Beaver & 4 & $<.002$ & -- & -- & $<.002$ & -- & -- & .003 \\
\hline Willamette River & 10 & $<.002$ & $<.002$ & $<.002$ & .004 & .007 & .024 & .026 \\
\hline Multnomah Channel & 4 & $<.002$ & -- & -- & .004 & -- & -- & .009 \\
\hline Sandy River & 3 & $<.002$ & -- & -- & $<.002$ & -- & -- & $<.002$ \\
\hline Lewis River & 4 & $<.002$ & -- & -- & $<.002$ & -- & -- & $<.002$ \\
\hline Kalama River & 4 & $<.002$ & -- & -- & $<.002$ & -- & -- & $<.002$ \\
\hline Cowlitz River & 4 & $<.002$ & -- & -- & $<.002$ & -- & -- & $<.002$ \\
\hline All sites & 45 & $<<.002$ & $<.002$ & $<.002$ & $<<.002$ & $<.002$ & .006 & .026 \\
\hline \multicolumn{9}{|c|}{ Diazinon } \\
\hline Warrendale & 4 & $<.002$ & -- & -- & $<.002$ & -- & -- & $<.002$ \\
\hline Hayden Island & 4 & $<.002$ & -- & -- & $<.002$ & -- & -- & $<.002$ \\
\hline Columbia City & 4 & $<.002$ & -- & -- & $<.002$ & -- & -- & $<.002$ \\
\hline Beaver & 4 & $<.002$ & -- & -- & $<.002$ & -- & -- & $<.002$ \\
\hline Willamette River & 10 & $<.002$ & $<.002$ & $<.002$ & .004 & .007 & .009 & .009 \\
\hline Multnomah Channel & 4 & $<.002$ & -- & -- & .003 & -- & -- & .006 \\
\hline Sandy River & 3 & $<.002$ & -- & -- & $<.002$ & -- & -- & $<.002$ \\
\hline Lewis River & 4 & $<.002$ & -- & -- & $<.002$ & -- & -- & $<.002$ \\
\hline Kalama River & 4 & $<.002$ & -- & -- & $<.002$ & -- & -- & $<.002$ \\
\hline Cowlitz River & 4 & $<.002$ & -- & -- & $<.002$ & -- & -- & $<.002$ \\
\hline All sites & 45 & <.002 & $<<.002$ & <<.002 & <<.002 & $\overline{c<.002}$ & $\overline{.006}$ & 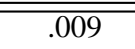 \\
\hline \multicolumn{9}{|c|}{ Eptam (EPTC) } \\
\hline Warrendale & 4 & $<.002$ & -- & -- & .002 & -- & -- & .006 \\
\hline
\end{tabular}


Table 36. Distribution of organic-compound concentrations in filtered water, lower Columbia River Basin, Oregon and Washington, 1994-Continued

[The term "filtered water" is an operational definition referring to the chemical analysis of that portion of a water-suspended sediment sample that passes through a nominal 0.70-micrometer filter; to avoid statistical bias that may be associated with constituents analyzed more than once at a site, only one element concentration per month was statistically summarized; concentrations are reported in micrograms per liter; acetochlor, azinphos-methyl, benfluralin, butylate, cyanazine, 4,4'-DDE, dieldrin, 2,6-diethylaniline, dimethoate, disulfoton, ethalfluralin, alpha-HCH, gamma-HCH (lindane), linuron, malathion, methyl parathion, molinate, parathion, pebulate, pendimethalin, cis-permethrin, phorate, propachlor, propanil, propargite, tebuthiuron, terbufos, thiobencarb, and trifluralin are not included in this table, because no samples had concentrations greater than their corresponding method detection limit; see table 9 for Chemical Abstracts Services registry numbers and method detection limits; see table 7 for full site names; -- indicates fewer than 6 samples were collected, therefore the percentile was not calculated; <, less than]

\begin{tabular}{|c|c|c|c|c|c|c|c|c|}
\hline \multirow{2}{*}{ Site name } & \multirow{2}{*}{$\begin{array}{l}\text { Number } \\
\text { of } \\
\text { samples }\end{array}$} & \multirow{2}{*}{$\begin{array}{l}\text { Minimum } \\
\text { value }\end{array}$} & \multicolumn{5}{|c|}{ Value at indicated percentile } & \multirow{2}{*}{$\begin{array}{l}\text { Maximum } \\
\text { value }\end{array}$} \\
\hline & & & 10 & 25 & 50 & 75 & 90 & \\
\hline \multicolumn{9}{|c|}{ Eptam (EPTC)-Continued } \\
\hline Hayden Island & 4 & $<0.002$ & -- & -- & $<0.002$ & -- & -- & 0.004 \\
\hline Columbia City & 4 & $<.002$ & -- & -- & $<.002$ & -- & -- & .005 \\
\hline Beaver & 4 & $<.002$ & -- & -- & $<.002$ & -- & -- & $<.002$ \\
\hline Willamette River & 10 & $<.002$ & $<.002$ & $<.002$ & $<.002$ & 0.004 & 0.005 & .005 \\
\hline Multnomah Channel & 4 & $<.002$ & -- & -- & $<.002$ & -- & -- & .006 \\
\hline Sandy River & 3 & $<.002$ & -- & -- & $<.002$ & -- & -- & $<.002$ \\
\hline Lewis River & 4 & $<.002$ & -- & -- & $<.002$ & -- & -- & $<.002$ \\
\hline Kalama River & 4 & $<.002$ & -- & -- & $<.002$ & -- & -- & $<.002$ \\
\hline Cowlitz River & 4 & $<.002$ & -- & -- & $<.002$ & -- & -- & $<.002$ \\
\hline All sites & 45 & $<.002$ & $<<.002$ & $<.002$ & $<.002$ & $<<.002$ & .005 & .006 \\
\hline \multicolumn{9}{|c|}{ Ethoprop } \\
\hline Warrendale & 4 & $<.003$ & -- & -- & $<.003$ & -- & -- & $<.003$ \\
\hline Hayden Island & 4 & $<.003$ & -- & -- & $<.003$ & -- & -- & $<.003$ \\
\hline Columbia City & 4 & $<.003$ & -- & -- & $<.003$ & -- & -- & $<.003$ \\
\hline Beaver & 4 & $<.003$ & -- & -- & $<.003$ & -- & -- & $<.003$ \\
\hline Willamette River & 10 & $<.003$ & $<.003$ & $<.003$ & $<.003$ & .008 & .022 & .023 \\
\hline Multnomah Channel & 4 & $<.003$ & -- & -- & $<.003$ & -- & -- & $<.003$ \\
\hline Sandy River & 3 & $<.003$ & -- & -- & $<.003$ & -- & -- & $<.003$ \\
\hline Lewis River & 4 & $<.003$ & -- & -- & $<.003$ & -- & -- & $<.003$ \\
\hline Kalama River & 4 & $<.003$ & -- & -- & $<.003$ & -- & -- & $<.003$ \\
\hline Cowlitz River & 4 & $<.003$ & -- & -- & $<.003$ & -- & -- & $<.003$ \\
\hline All sites & $\overline{445}$ & 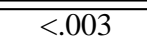 & $\overline{c<.003}$ & $<<.003$ & $<<.003$ & $\overline{c<.003}$ & $\overline{c<.003}$ & 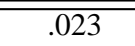 \\
\hline \multicolumn{9}{|c|}{ Fonofos } \\
\hline Warrendale & 4 & $<.003$ & -- & -- & $<.003$ & -- & -- & $<.003$ \\
\hline Hayden Island & 4 & $<.003$ & -- & -- & $<.003$ & -- & -- & $<.003$ \\
\hline Columbia City & 4 & $<.003$ & -- & -- & $<.003$ & -- & -- & $<.003$ \\
\hline Beaver & 4 & $<.003$ & -- & -- & $<.003$ & -- & -- & $<.003$ \\
\hline Willamette River & 10 & $<.003$ & $<.003$ & $<.003$ & $<.003$ & .005 & .010 & .010 \\
\hline Multnomah Channel & 4 & $<.003$ & -- & -- & $<.003$ & -- & -- & $<.003$ \\
\hline Sandy River & 3 & $<.003$ & -- & -- & $<.003$ & -- & -- & $<.003$ \\
\hline Lewis River & 4 & $<.003$ & -- & -- & $<.003$ & -- & -- & $<.003$ \\
\hline Kalama River & 4 & $<.003$ & -- & -- & $<.003$ & -- & -- & $<.003$ \\
\hline Cowlitz River & 4 & $<.003$ & -- & -- & $<.003$ & -- & -- & $<.003$ \\
\hline 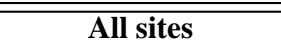 & $\overline{455}$ & <<.003 & $\overline{c<.003}$ & 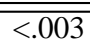 & $\overline{c<.003}$ & $\overline{c<.003}$ & $<<.003$ & 00.010 \\
\hline
\end{tabular}


Table 36. Distribution of organic-compound concentrations in filtered water, lower Columbia River Basin, Oregon and Washington, 1994-Continued

[The term "filtered water" is an operational definition referring to the chemical analysis of that portion of a water-suspended sediment sample that passes through a nominal 0.70-micrometer filter; to avoid statistical bias that may be associated with constituents analyzed more than once at a site, only one element concentration per month was statistically summarized; concentrations are reported in micrograms per liter; acetochlor, azinphos-methyl, benfluralin, butylate, cyanazine, 4,4'-DDE, dieldrin, 2,6-diethylaniline, dimethoate, disulfoton, ethalfluralin, alpha- $\mathrm{HCH}$, gamma- $\mathrm{HCH}$ (lindane), linuron, malathion, methyl parathion, molinate, parathion, pebulate, pendimethalin, cis-permethrin, phorate, propachlor, propanil, propargite, tebuthiuron, terbufos, thiobencarb, and trifluralin are not included in this table, because no samples had concentrations greater than their corresponding method detection limit; see table 9 for Chemical Abstracts Services registry numbers and method detection limits; see table 7 for full site names; -- indicates fewer than 6 samples were collected, therefore the percentile was not calculated; <, less than]

\begin{tabular}{|c|c|c|c|c|c|c|c|c|}
\hline \multirow{2}{*}{ Site name } & \multirow{2}{*}{$\begin{array}{c}\text { Number } \\
\text { of } \\
\text { samples }\end{array}$} & \multirow{2}{*}{$\begin{array}{l}\text { Minimum } \\
\text { value }\end{array}$} & \multicolumn{5}{|c|}{ Value at indicated percentile } & \multirow{2}{*}{$\begin{array}{l}\text { Maximum } \\
\text { value }\end{array}$} \\
\hline & & & 10 & 25 & 50 & 75 & 90 & \\
\hline \multicolumn{9}{|c|}{ Metolachlor } \\
\hline Warrendale & 4 & $<0.002$ & -- & -- & $<0.002$ & -- & -- & 0.004 \\
\hline Hayden Island & 4 & $<.002$ & -- & -- & $<.002$ & -- & -- & .002 \\
\hline Columbia City & 4 & $<.002$ & -- & -- & $<.002$ & -- & -- & .017 \\
\hline Beaver & 4 & $<.002$ & -- & -- & $<.002$ & -- & -- & .003 \\
\hline Willamette River & 10 & $<.002$ & $<0.002$ & 0.004 & .007 & 0.048 & 0.104 & .110 \\
\hline Multnomah Channel & 4 & $<.002$ & -- & -- & .006 & -- & -- & .044 \\
\hline Sandy River & 3 & $<.002$ & -- & -- & $<.002$ & -- & -- & $<.002$ \\
\hline Lewis River & 4 & $<.002$ & -- & -- & $<.002$ & -- & -- & $<.002$ \\
\hline Kalama River & 4 & $<.002$ & -- & -- & $<.002$ & -- & -- & $<.002$ \\
\hline Cowlitz River & 4 & $<.002$ & -- & -- & $<.002$ & -- & -- & $<.002$ \\
\hline$\overline{\text { All sites }}$ & $\overline{45}$ & $\overline{c<.002}$ & 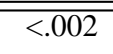 & $\overline{c<.002}$ & $<<.002$ & .004 & 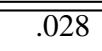 & 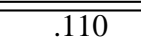 \\
\hline \multicolumn{9}{|c|}{ Metribuzin } \\
\hline Warrendale & 4 & $<.004$ & -- & -- & $<.004$ & -- & -- & $<.004$ \\
\hline Hayden Island & 4 & $<.004$ & -- & -- & $<.004$ & -- & -- & $<.004$ \\
\hline Columbia City & 4 & $<.004$ & -- & -- & $<.004$ & -- & -- & $<.004$ \\
\hline Beaver & 4 & $<.004$ & -- & -- & $<.004$ & -- & -- & $<.004$ \\
\hline Willamette River & 10 & $<.004$ & $<.004$ & $<.004$ & $<.004$ & .006 & .028 & .029 \\
\hline Multnomah Channel & 4 & $<.004$ & -- & -- & $<.004$ & -- & -- & .021 \\
\hline Sandy River & 3 & $<.004$ & -- & -- & $<.004$ & -- & -- & $<.004$ \\
\hline Lewis River & 4 & $<.004$ & -- & -- & $<.004$ & -- & -- & $<.004$ \\
\hline Kalama River & 4 & $<.004$ & -- & -- & $<.004$ & -- & -- & $<.004$ \\
\hline Cowlitz River & 4 & $<.004$ & -- & -- & $<.004$ & -- & -- & $<.004$ \\
\hline All sites & $\overline{445}$ & 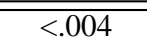 & 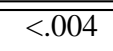 & <<.004 & $\overline{c<.004}$ & <<.004 & $\overline{c<.004}$ & 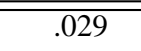 \\
\hline \multicolumn{9}{|c|}{ Napropamide } \\
\hline Warrendale & 4 & $<.003$ & -- & -- & $<.003$ & -- & -- & $<.003$ \\
\hline Hayden Island & 4 & $<.003$ & -- & -- & $<.003$ & -- & -- & .007 \\
\hline Columbia City & 4 & $<.003$ & -- & -- & $<.003$ & -- & -- & $<.003$ \\
\hline Beaver & 4 & $<.003$ & -- & -- & $<.003$ & -- & -- & $<.003$ \\
\hline Willamette River & 10 & $<.003$ & $<.003$ & $<.003$ & $<.003$ & .024 & .064 & .068 \\
\hline Multnomah Channel & 4 & $<.003$ & -- & -- & $<.003$ & -- & -- & $<.003$ \\
\hline Sandy River & 3 & $<.003$ & -- & -- & $<.003$ & -- & -- & $<.003$ \\
\hline
\end{tabular}


Table 36. Distribution of organic-compound concentrations in filtered water, lower Columbia River Basin, Oregon and Washington, 1994-Continued

[The term "filtered water" is an operational definition referring to the chemical analysis of that portion of a water-suspended sediment sample that passes through a nominal 0.70-micrometer filter; to avoid statistical bias that may be associated with constituents analyzed more than once at a site, only one element concentration per month was statistically summarized; concentrations are reported in micrograms per liter; acetochlor, azinphos-methyl, benfluralin, butylate, cyanazine, 4,4'-DDE, dieldrin, 2,6-diethylaniline, dimethoate, disulfoton, ethalfluralin, alpha- $\mathrm{HCH}$, gamma- $\mathrm{HCH}$ (lindane), linuron, malathion, methyl parathion, molinate, parathion, pebulate, pendimethalin, cis-permethrin, phorate, propachlor, propanil, propargite, tebuthiuron, terbufos, thiobencarb, and trifluralin are not included in this table, because no samples had concentrations greater than their corresponding method detection limit; see table 9 for Chemical Abstracts Services registry numbers and method detection limits; see table 7 for full site names; -- indicates fewer than 6 samples were collected, therefore the percentile was not calculated; <, less than]

\begin{tabular}{|c|c|c|c|c|c|c|c|c|}
\hline \multirow{2}{*}{ Site name } & \multirow{2}{*}{$\begin{array}{c}\text { Number } \\
\text { of } \\
\text { samples }\end{array}$} & \multirow{2}{*}{$\begin{array}{l}\text { Minimum } \\
\text { value }\end{array}$} & \multicolumn{5}{|c|}{ Value at indicated percentile } & \multirow{2}{*}{$\begin{array}{l}\text { Maximum } \\
\text { value }\end{array}$} \\
\hline & & & 10 & 25 & 50 & 75 & 90 & \\
\hline \multicolumn{9}{|c|}{ Napropamide-Continued } \\
\hline Lewis River & 4 & $<0.003$ & -- & -- & $<0.003$ & -- & -- & $<0.003$ \\
\hline Kalama River & 4 & $<.003$ & -- & -- & $<.003$ & -- & -- & $<.003$ \\
\hline Cowlitz River & 4 & $<.003$ & -- & -- & $<.003$ & -- & -- & $<.003$ \\
\hline All sites & $\overline{45}$ & $<<.003$ & $\overline{c<0.003}$ & $\overline{<<0.003}$ & $<<.003$ & 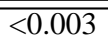 & $\overline{0.006}$ & .068 \\
\hline \multicolumn{9}{|c|}{ Prometon } \\
\hline Warrendale & 4 & $<.003$ & -- & -- & $<.003$ & -- & -- & $<.003$ \\
\hline Hayden Island & 4 & $<.003$ & -- & -- & $<.003$ & -- & -- & $<.003$ \\
\hline Columbia City & 4 & $<.003$ & -- & -- & $<.003$ & -- & -- & $<.003$ \\
\hline Beaver & 4 & $<.003$ & -- & -- & $<.003$ & -- & -- & $<.003$ \\
\hline Willamette River & 10 & $<.003$ & $<.003$ & $<.003$ & $<.003$ & $<.003$ & $<.003$ & .003 \\
\hline Multnomah Channel & 4 & $<.003$ & -- & -- & $<.003$ & -- & -- & $<.003$ \\
\hline Sandy River & 3 & $<.003$ & -- & -- & $<.003$ & -- & -- & $<.003$ \\
\hline Lewis River & 4 & $<.003$ & -- & -- & $<.003$ & -- & -- & $<.003$ \\
\hline Kalama River & 4 & $<.003$ & -- & -- & $<.003$ & -- & -- & $<.003$ \\
\hline Cowlitz River & 4 & $<.003$ & -- & -- & $<.003$ & -- & -- & $<.003$ \\
\hline All sites & 45 & $<<.003$ & $<<.003$ & $<<.003$ & $<<.003$ & $<<.003$ & $<<.003$ & .003 \\
\hline \multicolumn{9}{|c|}{ Pronamide } \\
\hline Warrendale & 4 & $<.018$ & -- & -- & $<.018$ & -- & -- & $<.018$ \\
\hline Hayden Island & 4 & $<.018$ & -- & -- & $<.018$ & -- & -- & $<.018$ \\
\hline Columbia City & 4 & $<.018$ & -- & -- & $<.018$ & -- & -- & $<.018$ \\
\hline Beaver & 4 & $<.018$ & -- & -- & $<.018$ & -- & -- & $<.018$ \\
\hline Willamette River & 10 & $<.018$ & $<.018$ & $<.018$ & $<.018$ & $<.018$ & .029 & .030 \\
\hline Multnomah Channel & 4 & $<.018$ & -- & -- & $<.018$ & -- & -- & $<.018$ \\
\hline Sandy River & 3 & $<.018$ & -- & -- & $<.018$ & -- & -- & $<.018$ \\
\hline Lewis River & 4 & $<.018$ & -- & -- & $<.018$ & -- & -- & $<.018$ \\
\hline Kalama River & 4 & $<.018$ & -- & -- & $<.018$ & -- & -- & $<.018$ \\
\hline Cowlitz River & 4 & $<.018$ & -- & -- & $<.018$ & -- & -- & $<.018$ \\
\hline All sites & 45 & $<.018$ & $<.018$ & $<.018$ & $<.018$ & $<.018$ & $<<.018$ & .030 \\
\hline \multicolumn{9}{|c|}{ Simazine } \\
\hline Warrendale & 4 & $<.005$ & -- & -- & $<.005$ & -- & -- & $<.005$ \\
\hline Hayden Island & 4 & $<.005$ & -- & -- & $<.005$ & -- & -- & $<.005$ \\
\hline Columbia City & 4 & $<.005$ & -- & -- & $<.005$ & -- & -- & .009 \\
\hline
\end{tabular}


Table 36. Distribution of organic-compound concentrations in filtered water, lower Columbia River Basin, Oregon and Washington, 1994-Continued

[The term "filtered water" is an operational definition referring to the chemical analysis of that portion of a water-suspended sediment sample that passes through a nominal 0.70-micrometer filter; to avoid statistical bias that may be associated with constituents analyzed more than once at a site, only one element concentration per month was statistically summarized; concentrations are reported in micrograms per liter; acetochlor, azinphos-methyl, benfluralin, butylate, cyanazine, 4,4'-DDE, dieldrin, 2,6-diethylaniline, dimethoate, disulfoton, ethalfluralin, alpha-HCH, gamma-HCH (lindane), linuron, malathion, methyl parathion, molinate, parathion, pebulate, pendimethalin, cis-permethrin, phorate, propachlor, propanil, propargite, tebuthiuron, terbufos, thiobencarb, and trifluralin are not included in this table, because no samples had concentrations greater than their corresponding method detection limit; see table 9 for Chemical Abstracts Services registry numbers and method detection limits; see table 7 for full site names; -- indicates fewer than 6 samples were collected, therefore the percentile was not calculated; <, less than]

\begin{tabular}{|c|c|c|c|c|c|c|c|c|}
\hline \multirow{2}{*}{ Site name } & \multirow{2}{*}{$\begin{array}{l}\text { Number } \\
\text { of } \\
\text { samples }\end{array}$} & \multirow{2}{*}{$\begin{array}{l}\text { Minimum } \\
\text { value }\end{array}$} & \multicolumn{5}{|c|}{ Value at indicated percentile } & \multirow{2}{*}{$\begin{array}{l}\text { Maximum } \\
\text { value }\end{array}$} \\
\hline & & & 10 & 25 & 50 & 75 & 90 & \\
\hline \multicolumn{9}{|c|}{ Simazine-Continued } \\
\hline Beaver & 4 & $<0.005$ & -- & -- & $<0.005$ & -- & -- & 0.011 \\
\hline Willamette River & 10 & .005 & 0.005 & 0.010 & .030 & 0.064 & 0.072 & .0730 \\
\hline Multnomah Channel & 4 & $<.005$ & -- & -- & .012 & -- & -- & .035 \\
\hline Sandy River & 3 & $<.005$ & -- & -- & $<.005$ & -- & -- & $<.005$ \\
\hline Lewis River & 4 & $<.005$ & -- & -- & $<.005$ & -- & -- & $<.005$ \\
\hline Kalama River & 4 & $<.005$ & -- & -- & $<.005$ & -- & -- & $<.005$ \\
\hline Cowlitz River & 4 & $<.005$ & -- & -- & $<.005$ & -- & -- & $<.005$ \\
\hline All sites & $\overline{45}$ & $<.005$ & $<<.005$ & $<.005$ & $<.005$ & .010 & .045 & .073 \\
\hline \multicolumn{9}{|c|}{ Terbacil } \\
\hline Warrendale & 4 & $<.007$ & -- & -- & $<.007$ & -- & -- & $<.007$ \\
\hline Hayden Island & 4 & $<.007$ & -- & -- & $<.007$ & -- & -- & $<.007$ \\
\hline Columbia City & 4 & $<.007$ & -- & -- & $<.007$ & -- & -- & $<.007$ \\
\hline Beaver & 4 & $<.007$ & -- & -- & $<.007$ & -- & -- & $<.007$ \\
\hline Willamette River & 10 & $<.007$ & $<.007$ & $<.007$ & $<.007$ & .028 & .075 & .080 \\
\hline Multnomah Channel & 4 & $<.007$ & -- & -- & $<.007$ & -- & -- & .012 \\
\hline Sandy River & 3 & $<.007$ & -- & -- & $<.007$ & -- & -- & $<.007$ \\
\hline Lewis River & 4 & $<.007$ & -- & -- & $<.007$ & -- & -- & $<.007$ \\
\hline Kalama River & 4 & $<.007$ & -- & -- & $<.007$ & -- & -- & $<.007$ \\
\hline Cowlitz River & 4 & $<.007$ & -- & -- & $<.007$ & -- & -- & $<.007$ \\
\hline All sites & 45 & $<<.007$ & $<<.007$ & $<<.007$ & $\begin{array}{l}<.007 \\
\end{array}$ & $<<.007$ & 0.014 & .080 \\
\hline \multicolumn{9}{|c|}{ Triallate } \\
\hline Warrendale & 4 & $<.001$ & -- & -- & $<.001$ & -- & -- & $<.001$ \\
\hline Hayden Island & 4 & $<.001$ & -- & -- & $<.001$ & -- & -- & $<.001$ \\
\hline Columbia City & 4 & $<.001$ & -- & -- & $<.001$ & -- & -- & $<.001$ \\
\hline Beaver & 4 & $<.001$ & -- & -- & $<.001$ & -- & -- & $<.001$ \\
\hline Willamette River & 10 & $<.001$ & $<.001$ & $<.001$ & $<.001$ & $<.001$ & .008 & .008 \\
\hline Multnomah Channel & 4 & $<.001$ & -- & -- & $<.001$ & -- & -- & $<.001$ \\
\hline Sandy River & 3 & $<.001$ & -- & -- & $<.001$ & -- & -- & $<.001$ \\
\hline Lewis River & 4 & $<.001$ & -- & -- & $<.001$ & -- & -- & $<.001$ \\
\hline Kalama River & 4 & $<.001$ & -- & -- & $<.001$ & -- & -- & $<.001$ \\
\hline Cowlitz River & 4 & $<.001$ & -- & -- & $<.001$ & -- & -- & $<.001$ \\
\hline All sites & $\overline{455}$ & 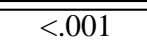 & $\overline{c<.001}$ & 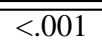 & 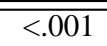 & $\overline{c<.001}$ & $\overline{c<.001}$ & 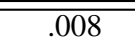 \\
\hline
\end{tabular}




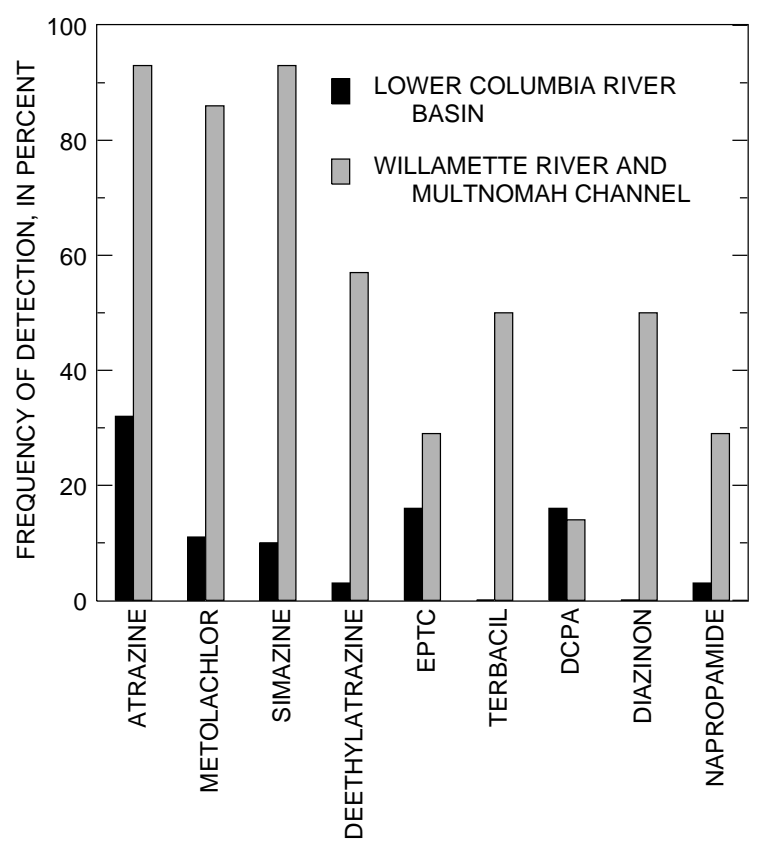

ORGANIC COMPOUND

Figure 34. Frequency of detection for selected organic compounds in the lower Columbia River Basin, Oregon and Washington, 1994. (Lower Columbia River Basin $=31$ samples and excludes the Willamette River at Portland and Multnomah Channel near mouth; Willamette River Basin = 14 samples and includes the Willamette River at Portland and Multnomah Channel near mouth)

$$
\mathrm{Kd}=\mathrm{Cs} / \mathrm{Ce}(2)
$$

where $\mathrm{Cs}$ is the concentration of atrazine sorbed to a specific weight of suspended sediment in nanograms per gram (ng/g) and Ce is the concentration of atrazine dissolved in an equal weight of water in nanograms per milliliter $(\mathrm{ng} / \mathrm{mL})$. During the November 3, 1994 sampling in the Willamette River, the foc was 0.03 , the concentration of dissolved atrazine was $0.130 \mathrm{ng} / \mathrm{mL}$, and the concentration of suspended sediment was $0.081 \mathrm{~g} / \mathrm{L}$. Thus, given a Koc of 160 and a foc of 0.03 ,

$$
\mathrm{Kd}(\mathrm{mL} / \mathrm{g})=160 \times 0.03=4.8 \mathrm{~mL} / \mathrm{g}
$$

When the Kd and the Willamette River's dissolved atrazine concentration are substituted into equation 2 ,

$$
\begin{aligned}
& 4.8 \mathrm{~mL} / \mathrm{g}=\mathrm{Ce} \mathrm{ng} / \mathrm{g} / 0.130 \mathrm{ng} / \mathrm{mL} \\
& \mathrm{Ce}=0.63 \mathrm{ng} / \mathrm{g}
\end{aligned}
$$

the concentration of atrazine on suspended sediment was equal to $0.63 \mathrm{ng} / \mathrm{g}$. The concentration of suspended sediment in the Willamette River was

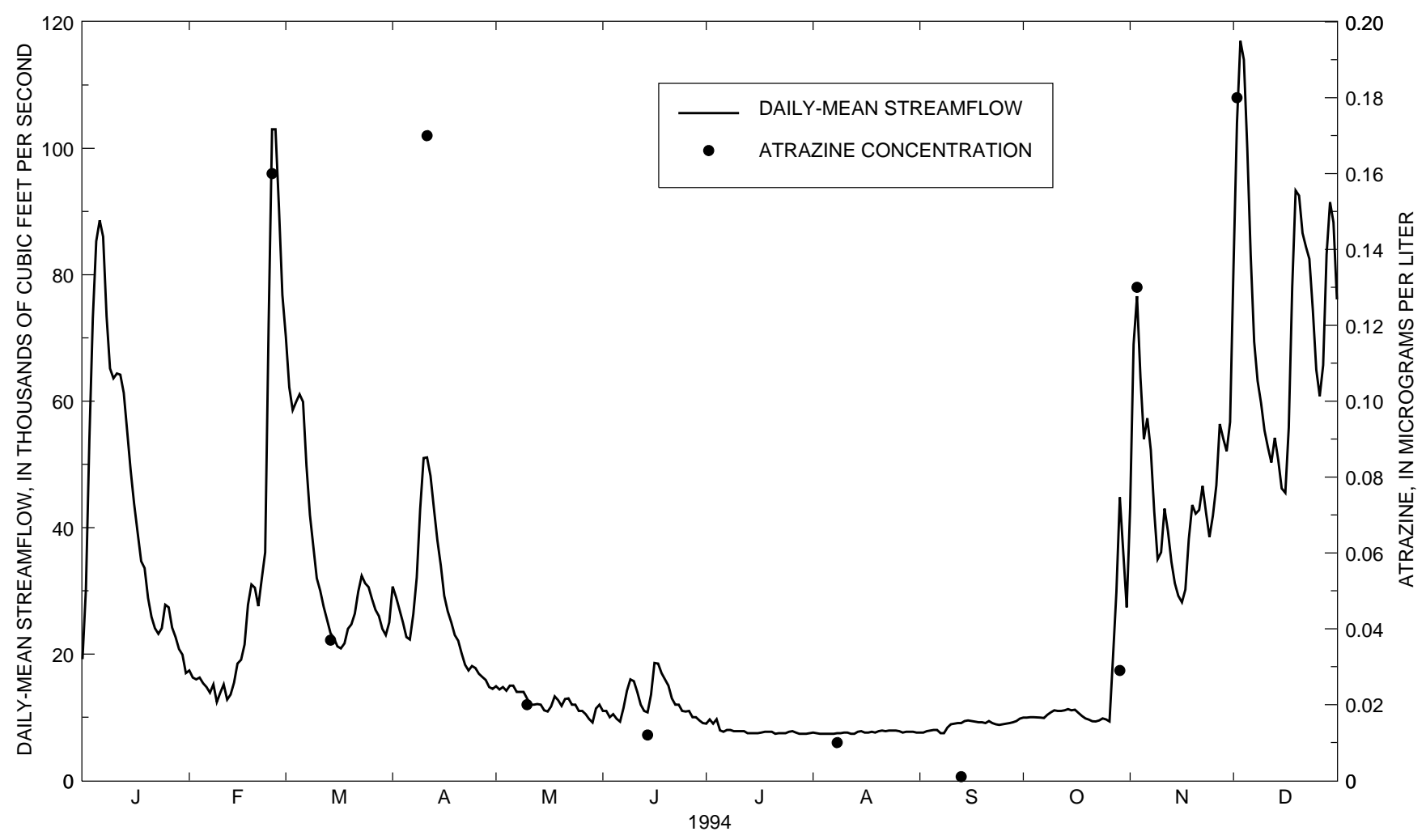

Figure 35. Relation between daily mean streamflow and atrazine concentrations in filtered water in the Willamette River at Portland, lower Columbia River Basin, Oregon, 1994. (The term "filtered water" is an operational definition referring to the chemical analysis of a water-suspended sediment sample that passes through a nominal 0.70-micrometer filter.) 
$0.081 \mathrm{~g} / \mathrm{L}$, thus $0.051 \mathrm{ng} / \mathrm{L}$ of atrazine was transported on suspended sediment and $0.130 \mathrm{ng} / \mathrm{mL}$ was transported in the dissolved phase. On the basis of this calculation, only 0.04 percent of the total atrazine was transported in the suspended phase. Using data from the December 2, 1994 sampling in the Willamette River, only 0.05 percent of the total atrazine was transported in the suspended phase.

Although equilibrium calculations clearly demonstrate atrazine's affinity for the dissolved phase, the presence of freshly eroded agricultural soils in waterways may enhance dissolved atrazine concentrations. The work of Squillace and Thurman (1992) suggests that atrazine concentrations in agricultural soils are high (greater than $2 \mathrm{mg} / \mathrm{g}$ [micrograms per gram]) following atrazine application in spring, because the organic-carbon content of soil typically ranges from 1 to 5 percent and the soil moisture is less than 20 percent. Under these conditions, 95 percent of the atrazine is sorbed to soils. During intense rainfall, however, atrazine temporarily may be transported on suspended sediment from agricultural fields to waterways. When the suspended-sediment concentration of the sediment-water mixture from the agricultural field decreases to less than $50 \mathrm{~g} / \mathrm{L}$, atrazine desorbs (50 percent sorbed) to the filtered form (Squillace and Thurman, 1992).

Concentrations of atrazine in the Willamette River from November to December were as large as $0.180 \mathrm{mg} / \mathrm{L}$ and affected atrazine concentrations in the main stem and Multnomah Channel (fig. 36). The effect on the lower Columbia River Basin of the high atrazine concentrations from the Willamette River was seen in the Multnomah Channel (0.16 $\mathrm{mg} / \mathrm{L}$ ) and Columbia River near Columbia City $(0.02 \mathrm{mg} / \mathrm{L})$. An identical, but attenuated, atrazine pattern exists from August to September, a period of low streamflow in the Willamette River and Columbia River (fig. 36). During August and September, atrazine was also measurable in the Columbia River at Beaver Army Terminal. Seasonal variations in simazine and metolachlor concentrations in the Willamette River and Columbia City closely mirror those of atrazine.

The significance of the Willamette River as a source of atrazine to the lower Columbia River is evident during periods of high streamflow in the Willamette River Basin. Between November 3rd
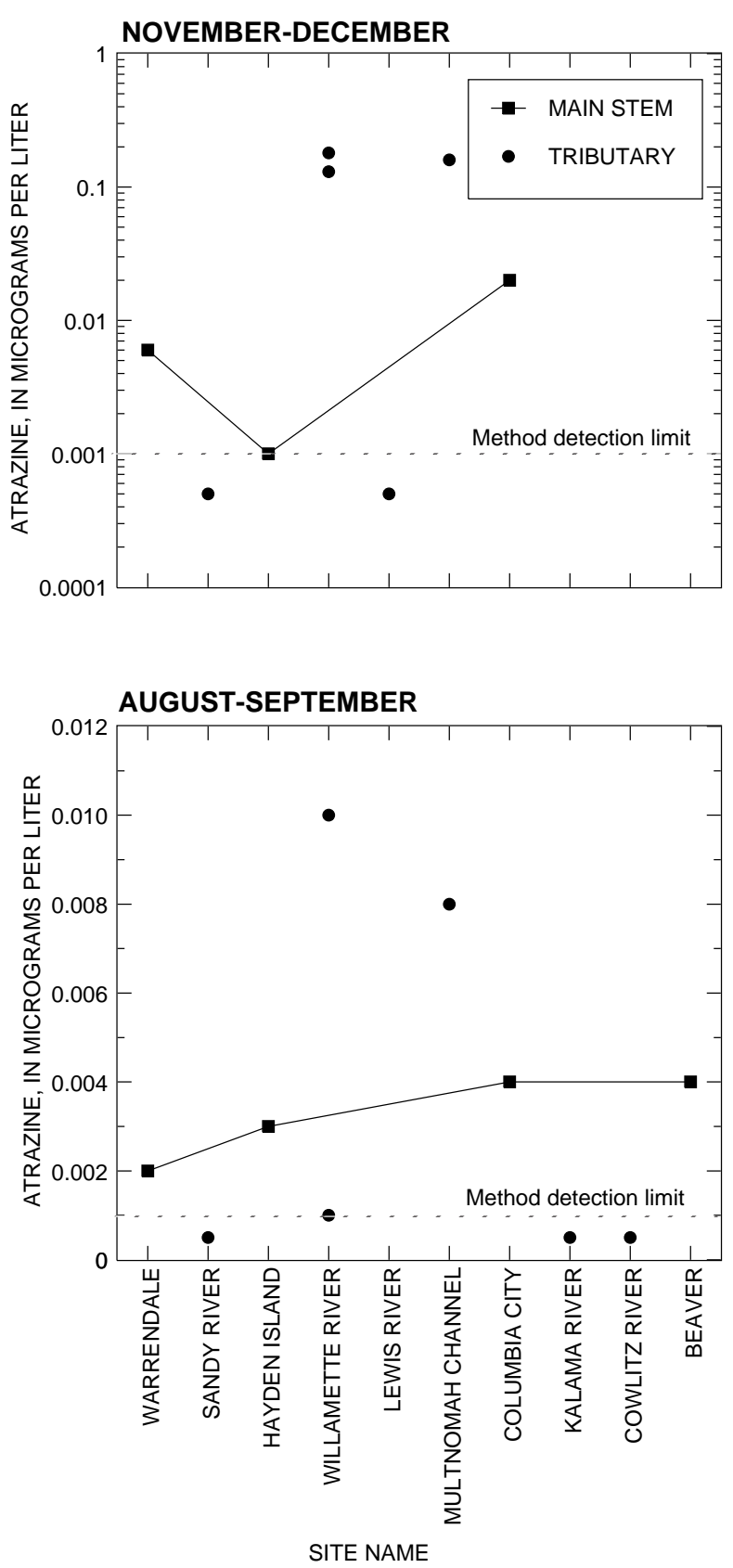

Figure 36. Atrazine concentrations in filtered water from November to December and from August to September, lower Columbia River Basin, Oregon and Washington, 1994 and 9th, 1994, atrazine was measured from filteredwater samples in the Columbia River at Warrendale (estimated $6 \mathrm{ng} / \mathrm{L}$ [nanograms per liter]), Willamette River at Portland (130 ng/L), and Columbia River near Columbia City (20 ng/L). The average daily mean streamflow in the Willamette River for this7day period $(47,000 \mathrm{ft} 3 / \mathrm{s})$ is high. On the basis of streamflow data for the period 1972-87 (Moffatt and others, 1990 , p. 292), a streamflow of $47,000 \mathrm{ft} 3 / \mathrm{s}$ was equaled or exceeded only about 27 percent of the time. During the 7-day period of sampling, the 
atrazine load in the Willamette River (54 lbs/d) was nearly 14 times that at Warrendale $(3.9 \mathrm{lbs} / \mathrm{d})$, while the streamflow in the Willamette River (although large for the Willamette River) was less than onehalf the average daily mean streamflow for thesame 7 -day period at Warrendale $(115,000 \mathrm{ft} 3 / \mathrm{s})$. The significance of the Willamette River atrazine load was further confirmed downstream in the Columbia River near Columbia City where an instantaneous atrazine load of $25 \mathrm{lbs} / \mathrm{d}$ was measured on November 9. The smaller atrazine load at Columbia City is probably a result of decreasing Willamette River streamflows, which decreased from 76,600 $\mathrm{ft}^{3} / \mathrm{s}$ on November 3 (the day the Willamette River was sampled) to only $43,000 \mathrm{ft}^{3} / \mathrm{s}$ on November 9 (the day Columbia City was sampled). Unquestionably, the Willamette River is the single largest source of atrazine to the lower Columbia River.

\section{Fecal-Indicator Bacteria}

The transmission of pathogenic microorganisms in water can be associated with fecal contamination from warm-blooded animals, including man (U.S. Environmental Protection Agency, 1976). Fecal-coliform, enterococcal, and fecal-streptococcal bacteria are indicators of fecal contamination in water. These bacteria are found in the gut of warm-blooded animals, but also may be associated with soils, vegetation, and insects. Thus, the occurrence of any of these bacteria does not conclusively indicate the presence of fecal contamination. Unless the source of the indicator bacteria has been determined by species identification to be nonfecal, the presence of an indicator bacterium indicates a potential health hazard.

Washington and Oregon standards for fecalindicator bacteria are based on EPA criteria (U.S. Environmental Protection Agency, 1976, 1986b). Currently (1994), the Columbia River is categorized as a class A stream by the WDOE (State of Washington, 1992), where fecal-coliform concentrations shall not exceed a geometric-mean concentration (based on at least five samples per month) of 100 colonies per $100 \mathrm{~mL}$ of water, with not more than 10 percent of the samples exceeding 200 colonies per $100 \mathrm{~mL}$. ODEQ's standard for indicator bacteria states that fecal-coliform concentrations should not exceed a log-mean concentration of 200 colonies per $100 \mathrm{~mL}$, with less than 10 percent of the samples exceeding 400 colonies per $100 \mathrm{~mL}$ (State of Oregon, 1994). Neither WDOE nor ODEQ had an enterococci standard in 1994. In 1992, Oregon had a geometricmean enterococci standard of 31 colonies per 100 $\mathrm{mL}$, with less than 61 colonies per $100 \mathrm{~mL}$ for 10 percent of the samples. Because the geometric- and log-mean values are used with at least five samples collected within 30 days, and because the current (1994) data set consists of monthly samples, the standard for Washington and Oregon of 200 and 400 fecal-coliform colonies, respectively, per $100 \mathrm{~mL}$ will apply. To aid in the screening of the data in this report, fresh waters regulated by Oregon with a concentration of 31 or more enterococci colonies per $100 \mathrm{~mL}$ or 200 or more fecal-coliform or fecalstreptococci colonies per $100 \mathrm{~mL}$ will be considered to be concentrations of concern (table 37). Fresh

Table 37. Indicator-bacteria standards and concentrations of concern for Oregon and Washington streams, lower Columbia River Basin, 1994

[Standards are the geometric or log mean of at least 5 samples collected within 1 month with not more than 10 percent of the samples exceeding two times the mean; since the data set for the lower Columbia River Basin includes only 1 sample per month, the higher values are used as the standard; values are reported in colonies per 100 milliliters of water; -- indicates not applicable]

\begin{tabular}{cccccc}
\hline & \multicolumn{2}{c}{ Standard } & \multicolumn{3}{c}{ Concern } \\
\cline { 2 - 5 } \cline { 5 - 5 } State & $\begin{array}{c}\text { Fecal } \\
\text { coliform }\end{array}$ & $\begin{array}{c}\text { Fecal } \\
\text { coliform }\end{array}$ & Enterococci & $\begin{array}{c}\text { Fecal } \\
\text { streptococci }\end{array}$ \\
\hline Oregon $^{\mathrm{a}}$ & 400 & 200 & $31^{\mathrm{b}}$ & 200 \\
Washington $^{\mathrm{c}}$ & 200 & 100 & -- & 100 \\
\hline
\end{tabular}

${ }^{\mathrm{a} S}$ State of Oregon, 1994.

${ }^{b}$ Federal standard is 33 per 100 milliliters,

U.S. Environmental Protection Agency, 1986b.

${ }^{\mathrm{c}}$ State of Washington, 1992.

waters regulated by Washington with a concentration of 100 or more colonies of fecal-coliform or fecalstreptococci colonies per $100 \mathrm{~mL}$ will also be considered of concern. Multiple-indicator bacterial tests have been used because of the high variability (lack of precision) within any one test. When different indicator tests have similar results, users of the data have greater assurance that the magnitude of observed concentrations are real and reproducible. 
For more detail, see the "Quality Assurance" section at the end of this report.

Table 38 presents a statistical summary of the indicator-bacteria data collected for each site during the 1994 sampling period. Only one sample, from more than 200 indicator-bacteria tests, exceeded the Washington State standard; the Oregon State standard was not exceeded. This single exceedance, which was from the Cowlitz River, is consistent with the results of an indicator-bacteria study performed by the WDOE in 1992 of recreational areas in the Columbia River (Washington Department of Ecology, 1993). In the WDOE study, fecal-coliform concentrations in samples from near the mouth of the Cowlitz River and near the mouth of the Willamette River also were found to exceed the State standards. Table 38 also shows that there were several sites and times when indicator-bacteria concentrations were at the level of concern. This is particularly true of the Willamette River at Portland and Columbia River at Beaver Army Terminal sites, at which there were concentrations of concern in more than one fecal-indicator test. However, for most of the time and for most of the other sites there were no concentrations of concern.

Analysis of the indicator-bacteria data for seasonal variability showed that many of the samples deemed "concentrations of concern" were collected in September, with higher concentrations also occurring in the months of January, April, October, November, and December. It is possible that fall and winter storms were responsible for the higher concentrations during these months.

However, a plot of streamflow versus bacteria count in the Columbia River did not reveal a significant relation. Very few high concentrations were observed during the months of June, July, and August. It is a positive sign, relative to humanhealth concerns, that during periods of high watercontact recreational activities, high bacteria counts were not observed.

To determine whether the patterns of indicator bacteria observed in 1994 were similar to concentrations over a longer time period, 1976-94 fecalcoliform data were analyzed from the USGS NASQAN sites at the Columbia River at Warrendale and Willamette River at Portland (fig. 37). The Columbia River at Warrendale has consistently had low concentrations of fecalcoliform bacteria with no significant seasonal
COLUMBIA RIVER AT WARRENDALE

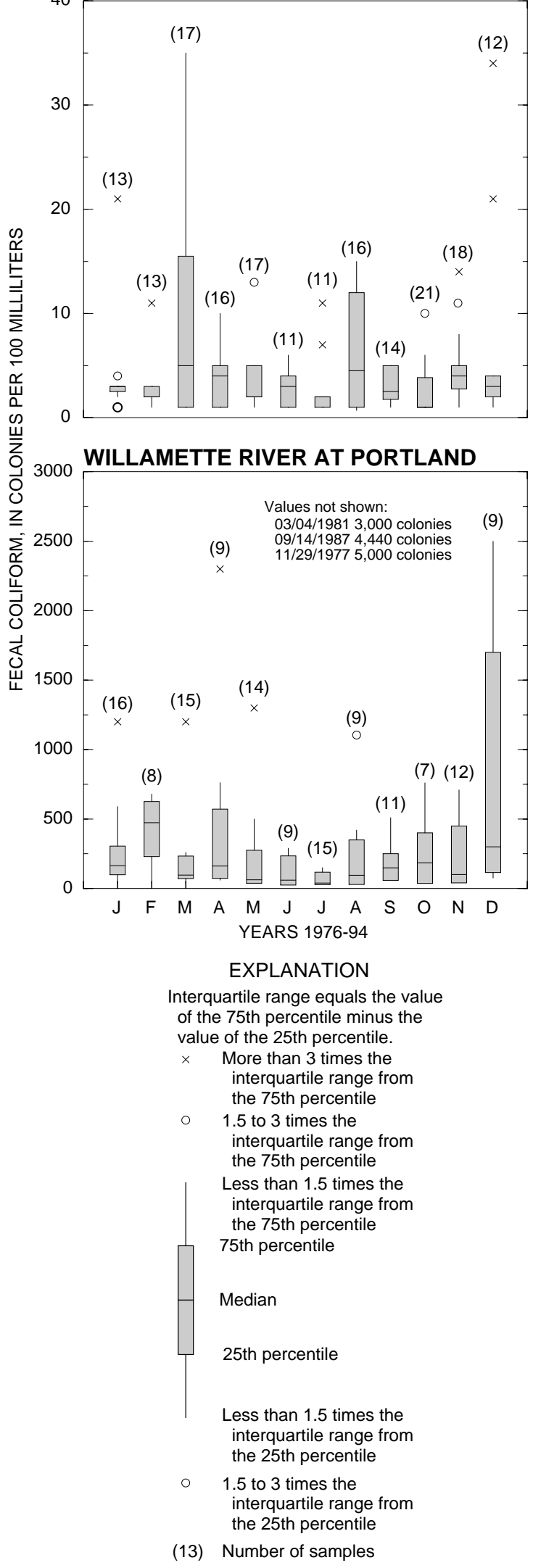

Figure 37. Distribution of fecal-coliform bacteria concentrations in the Columbia River at Warrendale and Willamette River at Portland, Oregon, 1976-94. 
Table 38. Distribution of fecal-indicator bacteria concentrations, lower Columbia River Basin, 1994

[To avoid statistical bias that may be associated with constituents analyzed more than once at a site, only one concentration per month was statistically summarized; values are reported in colonies per 100 milliliters of water; see table 7 for full site names; USGS, U.S. Geological Survey; ODEQ, Oregon Department of Environmental Quality; WDOE, Washington Department of Ecology; -- indicates fewer than 5 samples were collected, therefore the percentile was not calculated; a bold number indicates a concentration of concern; a bold number and shaded cell indicates a value that exceeds State standards; see table 37 for quantification of concentrations of concern and standards]

\begin{tabular}{|c|c|c|c|c|c|c|c|}
\hline \multirow{2}{*}{ Site name } & \multirow{2}{*}{ Agency } & \multirow{2}{*}{$\begin{array}{l}\text { Number of } \\
\text { samples }\end{array}$} & \multirow{2}{*}{$\begin{array}{l}\text { Minimum } \\
\text { value }\end{array}$} & \multicolumn{3}{|c|}{ Value at indicated percentile } & \multirow{2}{*}{$\begin{array}{l}\text { Maximum } \\
\text { value }\end{array}$} \\
\hline & & & & 25 & 50 & 75 & \\
\hline \multicolumn{8}{|c|}{ Fecal coliform } \\
\hline Warrendale & USGS & 11 & 1 & 1 & 2 & 3 & 5 \\
\hline Hayden Island & USGS & 12 & 3 & 5 & 8 & 17 & 100 \\
\hline Columbia City & USGS & 11 & 2 & 6 & 20 & 24 & 26 \\
\hline Beaver Army Terminal & USGS & 11 & 3 & 5 & 11 & 32 & 110 \\
\hline Sandy River & ODEQ & 10 & 2 & 4 & 8 & 33 & 130 \\
\hline Willamette River & USGS & 11 & 1 & 13 & 80 & 130 & 140 \\
\hline Willamette River & ODEQ & 8 & 4 & 11 & 19 & 106 & 170 \\
\hline Multnomah Channel & USGS & 11 & 9 & 16 & 24 & 62 & 160 \\
\hline Lewis River & USGS & 4 & 4 & -- & 6 & -- & 8 \\
\hline Lewis River & WDOE & 10 & 2 & 5 & 11 & 29 & 100 \\
\hline Kalama River & USGS & 4 & 12 & -- & 21 & -- & 30 \\
\hline Kalama River & WDOE & 10 & 2 & 5 & 12 & 52 & 71 \\
\hline Cowlitz River & USGS & 4 & 7 & -- & 10 & -- & 16 \\
\hline Cowlitz River & WDOE & 10 & 4 & 11 & 22 & 55 & 21,000 \\
\hline \multicolumn{8}{|c|}{ Enterococci } \\
\hline Warrendale & USGS & 10 & 1 & 1 & 1 & 3 & 25 \\
\hline Hayden Island & USGS & 12 & $<1$ & 1 & 4 & 6 & 9 \\
\hline Columbia City & USGS & 11 & 1 & 2 & 4 & 7 & 10 \\
\hline Beaver Army Terminal & USGS & 11 & 1 & 3 & 4 & 25 & 150 \\
\hline Sandy River & USGS & 4 & 4 & -- & 6 & -- & 33 \\
\hline Sandy River & ODEQ & 10 & 5 & 5 & 5 & 22 & 50 \\
\hline Willamette River & USGS & 12 & 6 & 16 & 26 & 71 & 520 \\
\hline Willamette River & ODEQ & 8 & 5 & 5 & 10 & 14 & 80 \\
\hline Multnomah Channel & USGS & 11 & 1 & 6 & 11 & 15 & 42 \\
\hline Lewis River & USGS & 4 & 1 & -- & 2 & -- & 5 \\
\hline Kalama River & USGS & 4 & 1 & -- & 6 & -- & 40 \\
\hline Cowlitz River & USGS & 4 & 1 & -- & 4 & -- & 57 \\
\hline \multicolumn{8}{|c|}{ Fecal streptococci } \\
\hline Warrendale & USGS & 6 & 1 & 1 & 1 & 3 & 5 \\
\hline Beaver Army Terminal & USGS & 6 & 2 & 7 & 34 & 140 & 440 \\
\hline Willamette River & USGS & 9 & 14 & 17 & 42 & 130 & 1,100 \\
\hline
\end{tabular}


variability. The Willamette River at Portland, however, had much higher, more variable concentrations, especially during fall and winter months, when storms are numerous. The likely explanation for the differences between these two sites is that the Columbia River site is not immediately below an urban area, whereas the Willamette River at Portland receives combined storm- and sanitary-sewer runoff during storms.

\section{Radionuclides}

Radionuclides in the lower Columbia River Basin were monitored by the Oregon Health Division from 1961 to 1993 (Oregon Health Division, Radiation Protection Services, 1994a, 1994b). No measured constituents exceeded any domestic or international standards during that period. However, concern about radionuclides does exist due to the Trojan nuclear power plant near Goble, Oregon, the Hanford Nuclear Reservation in eastern Washington, and fallout from nuclear testing and accidents worldwide.

Radionuclide activity in the Lower Columbia River, as measured at the Columbia River at Goble, Oregon (river mile 74), has declined dramatically since monitoring began there in 1962 (Oregon Health Division, 1994a, 1994b). Gross beta activity in surface waters at the Goble site has fallen from a maximum of $310 \mathrm{pCi} / \mathrm{L}$ (picocuries per liter) during the 1962 to 1967 period to a maximum of $4 \mathrm{pCi} / \mathrm{L}$ during the 1984 to 1993 period. In contrast, gross alpha activities in surface waters at the Goble site have remained constant, with a maximum of less than $2 \mathrm{pCi} / \mathrm{L}$ for $1968-72$ and $2 \mathrm{pCi} / \mathrm{L}$ for $1984-93$. No data are available for gross alpha at the Goble site for 1962-72.

Additionally, data indicate that radionuclide activities either declined or remained stable for streambed sediments and aquatic flora in the lower Columbia River. For example, Zn-65 activity in streambed sediments and Cladophora (an alga) declined from measured maximum activities of 100 and $340 \mathrm{pCi} /$ gram, respectively, during 1962-67 to less than 0.1 and less than $0.2 \mathrm{pCi} / \mathrm{gram}$, respectively, for 1978-83 (Oregon Health Division, 1994a, 1994b). Monitoring for Zn-65 activity in the lower Columbia River stopped in 1983. Those radionuclides measured during 1989-93 at GobleK-40, Ra-226, Cs-137, Be-7, Th-232-generally had low maximum activities in streambed sediments and Cladophora. In streambed sediments, measured maximum activities were 17.0, 0.8, 0.2, < 1.0, and $0.8 \mathrm{pCi} /$ gram, respectively. Similarly, in cladophora, measured maximum activities were $5.7,<0.2,<0.1$, and $1.1 \mathrm{pCi} / \mathrm{gram}$, respectively-Th-232 was not measured in Cladophora. Activities for K-40 were higher than other measured radionuclides, probably because it is naturally occurring. All measured activities were below standards established by international and domestic agencies for the Columbia River (Oregon Health Division, 1994a, 1994b).

\section{QUALITY ASSURANCE}

Quality-assurance data have been used, to the degree possible, in the $\mathrm{Bi}$-State monitoring program to quantify accuracy, precision, presence of laboratory contamination, and analytical bias. Analytical bias is important to the Bi-State program because water-quality data were collected and analyzed by multiple agencies (ODEQ, WDOE, and USGS) and laboratories. Statistics generated from the quality-assurance data were used in the interpretation of $\mathrm{Bi}-\mathrm{State}$ data and should be consulted by other users.

\section{Examples of Quality-Assurance Data}

The quality-assurance program for ambient monitoring involved various types of qualityassurance samples for constituents in filtered and unfiltered water and in suspended sediment. The types of quality assurance are as follows:

(A) SOURCE SOLUTION BLANKContaminant-free water (for example, distilled or deionized water) was shipped to the laboratory disguised as a routine sample. The source solution blank is a measure of contamination from sources other than sample collection and processing. For example, contaminants present in the atmosphere, on the interior of sample bottles, in preservatives, in the laboratory environment, and so on.

(B) FIELD EQUIPMENT BLANK-A volume of contaminant-free water is passed through all sampling and processing equipment that an ambient water sample would contact (for example, the sampler, sample splitter, pump, tubing, filter, filter 
holder, and sample bottle). The blank sample is then preserved and analyzed with the batch of actual samples. Field equipment blanks are used to show that (1) the equipment-cleaning protocol adequately removes contamination introduced from previous sampling, (2) the sampling and processing protocol does not result in contamination, and (3), the handling and transport of sampling equipment and supplies between sample collections do not introduce contamination.

(C) SPLIT SAMPLES - Large sample volumes of ambient water are divided into two or more equal volumes and sent to one or more laboratories. Split samples provide an estimate of precision within and between labs. These comparisons are especially important when multiple laboratories are used in a study. In the current study, samples were split using a 10-L churn splitter.

(D) STANDARD REFERENCE SAMPLESSamples of a known chemical concentration (analyzed multiple times to determine a most probable value [median] and an F-pseudosigma value $^{7}$ ) were disguised as routine samples and shipped to the laboratory. Reference samples do not come in contact with sampling or processing equipment. Results from standard reference samples are used to assess analytical accuracy.

(E) FIELD MATRIX SPIKES-A spike solution of known concentration is added to a split of ambient sample water and is processed and analyzed according to standard protocols. Samples may be sent to one lab or several laboratories. Field matrix spikes are used to assess analytical precision and recoveries of analytes from matrices of ambient water samples. Multiple split samples that have been spiked can be used to measure precision.

(F) SURROGATE SPIKES-Organic compounds that are expected to behave similarly to target analytes are spiked into each sample following filtration (to remove particulate matter) and prior to passing the sample through the solid phase extraction cartridge. Data from surrogate spikes are used to assess target analyte recovery and when aggregated over longer periods of time

\footnotetext{
${ }^{7}$ F-pseudosigma is equivalent to the standard deviation of traditional statistics when the data conform to a Gaussian distribution. Values greater than or less than the accepted value by 2 x F-pseudosigma, respectively, are considered lower- and upper-warning levels (Long and Farrar, 1995).
}

(months for example), can be used to assess long term analytical precision. Surrogate spike data are published in the USGS's water-data report (U.S. Geological Survey, 1995). Surrogate data should be interpreted with caution, however. Depending on conditions, surrogate recoveries may not be representative of all target analytes.

\section{Use of Quality-Assurance Results to Interpret Environmental Data}

The quality-assurance data have been organized and presented below to aid with the interpretation of the environmental data by quantifying accuracy, precision, bias, and contamination. To this end, the data have been organized into the following groups:

1. Field measurements;

2. Major ions;

3. Nutrients;

4. Indicator bacteria, chlorophyll $a$, suspended sediment, suspended solids, and organic carbon;

5. Filtered trace elements;

6. Suspended trace elements; and

7. Filtered organic compounds.

Although the quality-assurance data cover several constituent groups, data within each group were often few in number, which precluded a comprehensive analysis.

Table 39 lists quality-assurance data for field measurements of water temperature, specific conductance, $\mathrm{pH}$, dissolved oxygen, and alkalinity. On the basis of limited quality assurance data, water temperature, specific conductance, and alkalinity values were similar for ODEQ and USGS measurements in the Sandy River. For the current study, water temperature, specific conductance, and alkalinity data were aggregated into a single data set for interpretation. Dissolved oxygen and $\mathrm{pH}$ measurements between agencies were not comparable, however. Because the number of qualityassurance samples was small, it is not possible to conclude that differences exist between agencies. Instead, additional joint quality-assurance samples need to be collected. If differences exist between agencies, field sampling protocols should be amended accordingly.

Quality-assurance data for major ions collected by the USGS are listed in table 40 . Review of the split, standard-reference, and equipment-blank samples, respectively, show that precision, accuracy, 
Table 39. Quality-assurance data for field measurements, lower Columbia River Basin, Oregon, 1994 $\left[{ }^{\circ} \mathrm{C}\right.$, degrees Celsius; $\mu \mathrm{S} / \mathrm{cm}$, microsiemens per centimeter; $\mathrm{mg} / \mathrm{L}$, milligrams per liter; USGS, U.S. Geological Survey; ODEQ, Oregon Department of Environmental Quality; $\mathrm{CaCO}_{3}$, calcium carbonate]

\begin{tabular}{|c|c|c|c|c|c|c|c|c|}
\hline Site name & Agency & Date & Time & $\begin{array}{c}\text { Water } \\
\text { temperature, } \\
\text { in }{ }^{\circ} \mathbf{C}\end{array}$ & $\begin{array}{c}\text { Specific } \\
\text { conductance, } \\
\text { in } \mu \mathbf{S} / \mathbf{c m}\end{array}$ & $\begin{array}{l}\mathrm{pH} \text {, whole } \\
\text { water field, } \\
\text { in } \\
\text { standard } \\
\text { units }\end{array}$ & $\begin{array}{l}\text { Dissolved } \\
\text { oxygen, } \\
\text { in } \mathrm{mg} / \mathrm{L}\end{array}$ & $\begin{array}{c}\text { Alkalinity, } \\
\text { field } \\
\text { in } \mathrm{mg} / \mathrm{L} \\
\text { as } \\
\mathrm{CaCO}_{3}\end{array}$ \\
\hline $\begin{array}{l}\text { Sandy River } \\
\text { near Troutdale }\end{array}$ & USGS & 08-15-1994 & 1105 & 20.0 & 70 & 7.9 & 9.7 & 21 \\
\hline $\begin{array}{l}\text { Sandy River } \\
\text { near Troutdale }\end{array}$ & ODEQ & 08-15-1994 & 1025 & 19.0 & 72 & 7.5 & 9.0 & 20 \\
\hline
\end{tabular}

and absence of extraneous contamination were acceptable.

Analyses of a limited number of blind standard reference samples for nutrients show that the USGS laboratory had acceptable accuracy for its nutrient determinations (table 41). The only nutrient species close to a warning level was phosphorus in unfiltered water, for which standard reference samples N-38 and N-40 had concentrations near the lower warning level. For example, the phosphorus concentration for standard reference sample N-38 $(0.09 \mathrm{mg} / \mathrm{L})$ was smaller than the most probable value by $0.03 \mathrm{mg} / \mathrm{L}$, which slightly exceeds two times the F-pseudosigma value and is near the lower warning level. Analysis of the USGS depth- and width-integrated sample, split between the USGS and ODEQ laboratories, shows general agreement among nutrient species, and, likewise, no gross differences exist for the grab sample split between the USGS and ODEQ laboratories.

Laboratory precision associated with analyses of bacteria, chlorophyll $a$, and suspended sediment was assessed by splitting a depth- and widthintegrated sample between the USGS and ODEQ laboratories (table 42). Indicator bacteria counts for the ODEQ data were somewhat variable and exceeded counts made from the USGS split. These differences indicate the inherent difficulty in making intersite and intrasite comparisons of bacteria data. Although a grab sample for bacteria was collected, in addition to the depth- and widthintegrated sample, the data were too variable to assess differences in enumeration between sampling methods. The sample split for chlorophyll $a$ had a lower concentration in the USGS split than in the
ODEQ split; additionally, the ODEQ comparison for chlorophyll $a$ collected by depth- and widthintegrated versus grab-sampling techniques shows nearly identical concentrations between sampling methods. The differences in chlorophyll concentrations between laboratories may be indicative of variable precision; however, data are too few to make any definitive conclusion. The samples split between laboratories for comparison of the USGS suspended-sediment determination and the ODEQ suspended-solids determination had a suspended-sediment concentration in the USGS sample $(8 \mathrm{mg} / \mathrm{L})$ that was nearly three times higher than in the ODEQ split. Differences between laboratories may be indicative of the bias or discrimination inherent in grab sampling methods relative to obtaining representative quantities of coarsegrained suspended sediment. Ideally, however, tests for differences between sampling methods should be made during periods of high streamflow, when suspended sediment and coarse-grain sized sediment concentrations are high. Conversely, the similarity between the grab sample and the depth- and widthintegrated sample, which were both analyzed using the ODEQ suspended-solids method, suggests that differences may exist between the suspendedsediment and suspended-solids method. Last, USGS precision for suspended and filtered-water organiccarbon determinations was acceptable.

Quality-assurance data for filtered-water trace elements for the USGS included one split sample on the Sandy River, one laboratory blank, five equipment blanks, and one blind standard-reference sample (table 43). All quality-assurance samples were sent to the USGS laboratory as "blind samples." There were acceptable levels of precision 
Table 40. Quality-assurance data for major ions, lower Columbia River Basin, Oregon, 1994

[All values reported are from filtered-water samples; the term "filtered water" is an operational definition referring to the chemical analysis of that portion of a water-suspended sediment sample that passes through a nominal 0.45-micrometer filter; values are reported in milligrams per liter; silica is reported as $\mathrm{SiO}_{2}$; TDS, total dissolved solids at 180 degrees Celsius; Sandy River, Sandy River near Troutdale, Oregon; <, less than; --, not applicable; SRM, Standard-Reference Material; MPV, Most-Probable Value; F-pseudosigma is equivalent to one standard deviation for a normal data set]

\begin{tabular}{|c|c|c|c|c|c|c|c|c|c|c|c|}
\hline Sample description & Date & Time & Calcium & Magnesium & Sodium & Potassium & Chloride & Sulfate & Fluoride & Silica & TDS \\
\hline \multicolumn{12}{|c|}{ Split samples } \\
\hline Sandy River & 07-07-1994 & 1005 & 4.1 & 1.5 & 3.2 & 0.40 & 1.7 & 4.0 & $<0.10$ & 17 & -- \\
\hline Sandy River & 07-07-1994 & 1010 & 4.2 & 1.6 & 3.3 & .50 & 1.8 & 4.1 & $<.10$ & 17 & -- \\
\hline \multicolumn{12}{|c|}{ Blind standard-reference sample } \\
\hline SRM M-126 & 05-16-1994 & 1043 & 8.1 & 1.6 & 17 & 2.7 & -- & -- & -- & -- & -- \\
\hline MPV & -- & -- & 7.62 & 1.62 & 17.8 & 2.62 & -- & -- & -- & -- & -- \\
\hline F-pseudosigma & -- & -- & .46 & .078 & .77 & .178 & -- & -- & -- & -- & -- \\
\hline \multicolumn{12}{|c|}{ Equipment-blank sample } \\
\hline Equipment blank & 12-08-1994 & 1112 & $<.10$ & $<.10$ & $<.10$ & $<.10$ & -- & -- & -- & -- & $<1$ \\
\hline
\end{tabular}


Table 41. Quality-assurance data for nutrients, lower Columbia River Basin, Oregon, 1994

[All values reported are from filtered-water samples, unless otherwise stated; the term "filtered water" is an operational definition referring to the chemical analysis of that portion of a water-suspended sediment sample that passes through a nominal 0.45-micrometer filter; conversely, the term "unfiltered water" refers to the chemical analysis of a water sample that has not been filtered or centrifuged, nor in any way altered from the original matrix; values are reported in milligrams per liter; N, nitrogen; USGS, U.S. Geological Survey; <, less than; ODEQ, Oregon Department of Environmental Quality; --, not analyzed or not applicable; SRM, Standard-Reference Material; MPV, Most-Probable Value; F-pseudosigma is equivalent to one standard deviation of a normal data set]

\begin{tabular}{|c|c|c|c|c|c|c|c|c|c|c|}
\hline Sample description & Date & Time & Ammonia & $\begin{array}{c}\text { Ammonia plus } \\
\text { organic } N\end{array}$ & $\begin{array}{c}\text { Ammonia plus } \\
\text { organic } \mathrm{N}, \\
\text { unfiltered }\end{array}$ & Nitrite & $\begin{array}{l}\text { Nitrite plus } \\
\text { nitrate }\end{array}$ & $\begin{array}{l}\text { Phos- } \\
\text { phorus }\end{array}$ & $\begin{array}{c}\text { Phos- } \\
\text { phorus, } \\
\text { unfiltered }\end{array}$ & $\begin{array}{l}\text { Orthophos- } \\
\text { phate }\end{array}$ \\
\hline \multicolumn{11}{|c|}{ Split samples between agencies } \\
\hline $\begin{array}{l}\text { Sandy River, USGS analysis of } \\
\text { USGS integrated sample }\end{array}$ & 08-15-1994 & 1105 & $<0.010$ & $<0.20$ & $<0.20$ & $<0.010$ & 0.074 & 0.020 & 0.020 & 0.007 \\
\hline $\begin{array}{l}\text { Sandy River, ODEQ analysis of } \\
\text { USGS integrated sample }\end{array}$ & 08-15-1994 & 1020 & -- & -- & -- & .020 & $<.20$ & .020 & .020 & .006 \\
\hline $\begin{array}{l}\text { Sandy River, USGS analysis of } \\
\text { ODEQ grab sample }\end{array}$ & 08-15-1994 & 1024 & $<.010$ & $<.20$ & $<.20$ & $<.010$ & $<.050$ & .010 & .010 & .010 \\
\hline $\begin{array}{l}\text { Sandy River, ODEQ analysis of } \\
\text { ODEQ grab sample }\end{array}$ & 08-15-1994 & 1025 & .040 & -- & $<.20$ & -- & .030 & -- & .030 & .007 \\
\hline \multicolumn{11}{|c|}{ Blind standard-reference samples } \\
\hline USGS analysis of SRM N-38 & 08-15-1994 & 1110 & .070 & $<.20$ & $<.20$ & .060 & .200 & .100 & .090 & .116 \\
\hline MPV for N-38 & -- & -- & .087 & -- & .20 & -- & .210 & -- & .120 & .120 \\
\hline F-pseudosigma for N-38 & -- & -- & .017 & -- & .158 & -- & .018 & -- & .0126 & .0141 \\
\hline USGS analysis of SRM N-40 & 08-31-1994 & 1047 & $<.010$ & $<.20$ & .20 & .030 & .120 & .050 & .040 & .051 \\
\hline MPV for $\mathrm{N}-40$ & -- & -- & .024 & -- & .118 & -- & .110 & -- & .060 & .052 \\
\hline F-pseudosigma for $\mathrm{N}-40$ & -- & -- & .027 & -- & .098 & -- & .012 & -- & .010 & .005 \\
\hline \multicolumn{11}{|c|}{ USGS split samples } \\
\hline Sandy River & 07-07-1994 & 1005 & .010 & $<.20$ & $<.20$ & $<.010$ & $<.050$ & $<.010$ & $<.010$ & .003 \\
\hline Sandy River & 07-07-1994 & 1010 & .010 & $<.20$ & $<.20$ & $<.010$ & $<.050$ & $<.010$ & .010 & .004 \\
\hline
\end{tabular}


Table 42. Quality-assurance data for fecal-indicator bacteria, chlorophyll a, suspended sediment, suspended solids, and organic carbon, lower Columbia River Basin, Oregon, 1994

[cols/100mL, colonies per 100 milliliters of water; $\mathrm{mg} / \mathrm{L}$, milligrams per liter; the term "filtered water" is an operational definition referring to the chemical analysis of that portion of a water-suspended sediment sample that passes through a nominal 0.45-micrometer filter; Sandy River, Sandy River near Troutdale, Oregon; USGS, U.S. Geological Survey; K, nonideal bacteria count; --, not analyzed or not applicable; ODEQ, Oregon Department of Environmental Quality]

\begin{tabular}{|c|c|c|c|c|c|c|c|c|c|}
\hline Sample description & Date & Time & $\begin{array}{c}\begin{array}{c}\text { Fecal } \\
\text { coliform, } \\
\text { in cols/ } \\
100 \mathrm{~mL}\end{array}\end{array}$ & $\begin{array}{l}\text { Enterococci, } \\
\text { in cols/ } \\
100 \mathrm{~mL}\end{array}$ & $\begin{array}{l}\text { Chlorophyll } a \text {, } \\
\text { in } \mathbf{~ m g / L ~}\end{array}$ & $\begin{array}{l}\text { Suspended } \\
\text { sediment, } \\
\text { in } \mathrm{mg} / \mathrm{L}\end{array}$ & $\begin{array}{c}\text { Suspended } \\
\text { solids, } \\
\text { in } \mathrm{mg} / \mathrm{L}\end{array}$ & $\begin{array}{l}\text { Filtered } \\
\text { organic } \\
\text { carbon, } \\
\text { in } \mathrm{mg} / \mathrm{L}\end{array}$ & $\begin{array}{c}\text { Suspended } \\
\text { organic } \\
\text { carbon, } \\
\text { in } \mathrm{mg} / \mathrm{L}\end{array}$ \\
\hline \multicolumn{10}{|c|}{ Split samples between agencies } \\
\hline $\begin{array}{l}\text { Sandy River, USGS analysis of } \\
\text { USGS integrated sample }\end{array}$ & 08-15-1994 & 1105 & K 4 & K 4 & 1.0 & 8 & -- & -- & -- \\
\hline $\begin{array}{l}\text { Sandy River, ODEQ analysis of } \\
\text { USGS integrated sample }\end{array}$ & 08-15-1994 & 1020 & 11 & 45 & 3.0 & -- & 3 & -- & -- \\
\hline $\begin{array}{l}\text { Sandy River, ODEQ analysis of } \\
\text { ODEQ grab sample }\end{array}$ & 08-15-1994 & 1025 & 17 & 10 & 3.2 & -- & 3 & -- & -- \\
\hline \multicolumn{10}{|c|}{ USGS split samples } \\
\hline Sandy River & 07-07-1994 & 1005 & -- & -- & -- & -- & -- & 0.9 & 0.3 \\
\hline Sandy River & 07-07-1994 & 1010 & -- & -- & -- & -- & -- & .8 & .3 \\
\hline
\end{tabular}


Table 43. Quality-assurance data for filtered-water trace elements, lower Columbia River Basin, Oregon, 1994

[The term "filtered water" is an operational definition referring to the chemical analysis of that portion of a water-suspended sediment sample that passes through a nominal 0.45 -micrometer filter; values are reported in micrograms per liter; Sandy River, Sandy River near Troutdale, Oregon; <, less than; --, not analyzed or not applicable; SRM, Standard-Reference Material; MPV, Most-Probable Value;

F-pseudosigma is equivalent to one standard deviation for a normal data set]

\begin{tabular}{|c|c|c|c|c|c|c|c|c|c|c|c|c|}
\hline Sample description & Date & Time & Arsenic & Barium & Beryllium & Cadmium & Chromium & Cobalt & Copper & Iron & Lead & Manganese \\
\hline \multicolumn{13}{|c|}{ Split samples } \\
\hline Sandy River & 07-07-1994 & 1005 & $<1$ & 2 & $<1$ & $<1$ & $<1$ & $<1$ & $<1$ & 44 & $<1$ & 3 \\
\hline Sandy River & 07-07-1994 & 1010 & $<1$ & 2 & $<1$ & $<1$ & $<1$ & $<1$ & $<1$ & 43 & $<1$ & 3 \\
\hline \multicolumn{13}{|c|}{ Blank samples } \\
\hline Laboratory blank & 01-20-1994 & 1130 & $<1$ & $<1$ & $<1$ & $<1$ & $<1$ & $<1$ & $<1$ & -- & $<1$ & $<1$ \\
\hline Equipment blank & 02-16-1994 & 0927 & $<1$ & $<1$ & $<1$ & $<1$ & $<1$ & $<1$ & $<1$ & -- & $<1$ & $<1$ \\
\hline Equipment blank & 04-20-1994 & 1021 & $<1$ & $<1$ & $<1$ & $<1$ & $<1$ & $<1$ & $<1$ & -- & $<1$ & $<1$ \\
\hline Equipment blank & 05-11-1994 & 0947 & $<1$ & $<1$ & $<1$ & $<1$ & $<1$ & $<1$ & $<1$ & -- & $<1$ & $<1$ \\
\hline Equipment blank & 06-29-1994 & 1033 & $<1$ & $<1$ & $<1$ & $<1$ & $<1$ & $<1$ & $<1$ & -- & $<1$ & $<1$ \\
\hline Equipment blank & 08-10-1994 & 1027 & $<1$ & $<1$ & $<1$ & $<1$ & $<1$ & $<1$ & $<1$ & -- & $<1$ & $<1$ \\
\hline \multicolumn{13}{|c|}{ Blind standard-reference sample } \\
\hline SRM T-125 & 05-16-1994 & 1048 & 10 & 17 & 16 & 7 & 4 & 9 & 17 & -- & 8 & 16 \\
\hline MPV & -- & -- & 10.2 & 16.9 & 15.0 & 7.2 & 3.99 & 9.45 & 17.4 & -- & 8.11 & 18.0 \\
\hline F-pseudosigma & -- & -- & 1.54 & 1.67 & 1.19 & .75 & .71 & .78 & 2.08 & -- & 122 & 1.22 \\
\hline
\end{tabular}


Table 43. Quality-assurance data for filtered-water trace elements, lower Columbia River Basin, Oregon, 1994—Continued

[The term "filtered water" is an operational definition referring to the chemical analysis of that portion of a water-suspended sediment sample that passes through a nominal 0.45 -micrometer filter; values are reported in micrograms per liter; Sandy River, Sandy River near Troutdale, Oregon; <, less than; --, not analyzed or not applicable; SRM, Standard-Reference Material; MPV, Most-Probable Value; F-

pseudosigma is equivalent to one standard deviation for a normal data set

\begin{tabular}{|c|c|c|c|c|c|c|c|c|c|c|c|}
\hline Sample description & Date & Time & Molybdenum & Nickel & Silver & Zinc & Antimony & Aluminum & Selenium & Uranium & Mercury \\
\hline \multicolumn{12}{|c|}{ Split samples } \\
\hline Sandy River & 07-07-1994 & 1005 & $<1$ & $<1$ & $<1$ & 2 & $<1$ & 10 & $<1$ & $<1$ & $<0.1$ \\
\hline Sandy River, & 07-07-1994 & 1010 & $<1$ & $<1$ & $<1$ & $<1$ & $<1$ & 10 & $<1$ & $<1$ & $<.1$ \\
\hline \multicolumn{12}{|c|}{ Blank samples } \\
\hline Laboratory blank & 01-20-1994 & 1130 & $<1$ & $<1$ & $<1$ & $<1$ & $<1$ & $<1$ & $<1$ & $<1$ & -- \\
\hline Equipment blank & 02-16-1994 & 0927 & $<1$ & $<1$ & $<1$ & $<1$ & $<1$ & 3 & $<1$ & $<1$ & -- \\
\hline Equipment blank & 04-20-1994 & 1021 & $<1$ & $<1$ & $<1$ & $<1$ & $<1$ & 2 & $<1$ & $<1$ & -- \\
\hline Equipment blank & 05-11-1994 & 0947 & $<1$ & $<1$ & $<1$ & $<1$ & $<1$ & $<1$ & $<1$ & $<1$ & -- \\
\hline Equipment blank & 06-29-1994 & 1033 & $<1$ & $<1$ & $<1$ & 1 & $<1$ & $<1$ & $<1$ & $<1$ & $<.1$ \\
\hline Equipment blank & 08-10-1994 & 1027 & $<1$ & 1 & $<1$ & 8 & $<1$ & $<1$ & $<1$ & $<1$ & $<.1$ \\
\hline \multicolumn{12}{|c|}{ Blind standard-reference sample } \\
\hline SRM T-125 & 05-16-1994 & 1048 & 19 & 10 & 4 & 4 & 6 & 20 & 9 & -- & -- \\
\hline MPV & -- & -- & 20.1 & 11.2 & 3.83 & 595 & 6.24 & 24 & 9.78 & -- & -- \\
\hline F-pseudosigma & -- & -- & 1.78 & 1.04 & .60 & 4.01 & 1.30 & 8.56 & 1.85 & -- & -- \\
\hline
\end{tabular}


and accuracy for all constituents-trace elements were within two times the F-pseudosigma value. Equipment blanks were generally acceptable; however, small amounts of aluminum and nickel were detected infrequently. A higher single occurrence for zinc $(8 \mu \mathrm{g} / \mathrm{L})$ was measured on August 8, 1994, and may be indicative of contamination during sample processing and (or) analysis. The sample was rerun and the high zinc confirmed. Ambient waters analyzed during the month of August, however, had a maximum zinc concentration of only $2 \mu \mathrm{g} / \mathrm{L}$. Consequently, the source of the anomalous zinc concentration is unclear. The anomaly is of little significance to the interpretation of current (1994) ambient zinc data owing to the absence of high zinc concentrations in ambient waters sampled during August 1994. High zinc values for ambient waters might have suggested a more pervasive zinc contamination problem. Overall, the infrequent occurrence of contamination in USGS blanks suggests that the parts-per-billion protocol (Horowitz and others, 1994) currently being used by the USGS is working well.

Quality-assurance data for suspended trace elements included a blind standard-reference sample and two split samples from the Willamette River at Portland (table 44). Comparison of the USGS results with the most-probable value given by Govindaraju (1994) showed accuracy to be within 25 percent, except for titanium, arsenic, molybdenum, selenium, yttrium, and ytterbium. The precision was also shown to be within 25 percent, except for arsenic, cadmium, copper, molybdenum, and thallium. Except for the constituents listed above, the results show precision and accuracy to be good for making comparisons between sites and times. Contamination is generally not expected to be a problem with suspended trace elements, because concentrations are measured in parts per million $(\mu \mathrm{g} / \mathrm{g})$.

A specific quality-assurance program was designed to assess accuracy, precision, and contamination associated with field collection and laboratory analysis of organic compounds.

Accuracy was assessed by using field matrix spikes. Precision was assessed by using ambient river-water splits and field matrix spikes. Contamination was assessed by using organic-free water for fieldequipment blanks. All four field-equipment blank samples were less than the method detection limit for all analytes. Laboratory surrogate recovery results are published with the corresponding analytical data in the U.S. Geological Survey Water Resources Data Reports for Oregon for the 1994 WY (U.S. Geological Survey, 1995). Laboratory surrogate recoveries provide an indication of the recovery of the target organic compounds.

Statistical summaries for field matrix spike recoveries show that median recoveries ranged from as low as 20 percent for cis-Permethrin to as high as 130 percent for methyl parathion and terbufos (table 45). Calculations for the seven field matrix spikes were made by subtracting the environmental or ambient organic compound concentration (background) from the spiked environmental sample matrix. The theoretical spike concentration was calculated by determining the mass of the organic compound added to the environmental sample and dividing by the volume of the spiked sample. Recovery was subsequently calculated by dividing the background corrected spike concentration by the theoretical spiked concentration, and the minimum, median, and maximum recoveries, in percent, are shown in table 45 . When the environmental concentration was less than the method detection limit, its concentration was assumed to be zero for computation purposes. This was the case in about 85 percent of the calculations.

River-water samples were collected and split to make two replicate samples at each of four sites. Replicate results are listed in table 45 as the difference between the analytical-replicate results and the mean of the two values (rounded to the nearest even nanograms per liter). When one of the two concentrations was below the method detection limit, both measured values were reported.

\section{CONSIDERATIONS FOR FUTURE DATA- COLLECTION ACTIVITIES}

The goals of the Bi-State ambient-monitoring program were to define existing water-quality conditions, characterize water-quality problems according to magnitude and type, and provide waterquality information to support pollution prevention, abatement, and resource-management programs. Additionally, ambient-monitoring programs can provide data for evaluating compliance, effectiveness of pollution-prevention programs, and 
Table 44. Quality-assurance data for suspended trace element samples, lower Columbia River Basin, Oregon, 1994

[All values are reported in micrograms per gram, except aluminum, calcium, iron, magnesium, phosphorus, potassium, sodium, and titanium which are in percent; Willamette River, Willamette River at Portland, Oregon; SRM, Standard-Reference Material; --, not analyzed or not applicable; MPV, Most-Probable Value]

\begin{tabular}{|c|c|c|c|c|c|c|c|c|c|c|c|c|c|}
\hline $\begin{array}{c}\text { Sample } \\
\text { description }\end{array}$ & Date & Time & Aluminum & Calcium & Iron & $\begin{array}{l}\text { Magne- } \\
\text { sium }\end{array}$ & $\begin{array}{l}\text { Phos- } \\
\text { phorus }\end{array}$ & Potassium & Sodium & Titanium & Antimony & Arsenic & Barium \\
\hline \multicolumn{14}{|c|}{ Split samples } \\
\hline $\begin{array}{l}\text { Willamette } \\
\text { River }\end{array}$ & 04-11-1994 & 1000 & 8.2 & 1.5 & 5.8 & 1.1 & 0.16 & 0.96 & 0.94 & 0.78 & 0.60 & 6.9 & 470 \\
\hline $\begin{array}{l}\text { Willamette } \\
\text { River }\end{array}$ & 04-11-1994 & 1005 & 8.3 & 1.5 & 5.9 & 1.1 & .15 & .96 & .98 & .77 & .50 & 5.8 & 480 \\
\hline $\begin{array}{l}\text { Willamette } \\
\text { River }\end{array}$ & 11-03-1994 & 0956 & 8.8 & 1.9 & 6.1 & 1.1 & .15 & .94 & 1.20 & .76 & 1.10 & 8.0 & 500 \\
\hline $\begin{array}{l}\text { Willamette } \\
\text { River }\end{array}$ & 11-03-1994 & 1001 & 8.8 & 1.9 & 5.8 & 1.1 & .16 & .97 & 1.2 & .76 & .90 & 5.0 & 480 \\
\hline \multicolumn{14}{|c|}{ Blind standard-reference sample } \\
\hline SRM GSD-4 & 06-30-1994 & 1200 & 8.2 & 5.5 & 4.0 & .6 & .05 & 1.8 & .22 & .37 & 1.8 & 16 & 440 \\
\hline MPV & -- & -- & 8.29 & 5.38 & 4.13 & .63 & .048 & 1.85 & .223 & .534 & 1.84 & 19.7 & 470 \\
\hline
\end{tabular}

\begin{tabular}{|c|c|c|c|c|c|c|c|c|c|c|c|c|c|}
\hline $\begin{array}{c}\text { Sample } \\
\text { description }\end{array}$ & Date & Time & Beryllium & Cadmium & Chromium & Copper & Lead & Manganese & Mercury & Molybdenum & Nickel & Selenium & Silver \\
\hline \multicolumn{14}{|c|}{ Split samples } \\
\hline $\begin{array}{l}\text { Willamette } \\
\text { River }\end{array}$ & 04-11-1994 & 1000 & $<2.0$ & 0.30 & 80 & 66 & 15 & 1,500 & 1.50 & 1.00 & 36 & 0.60 & 0.70 \\
\hline $\begin{array}{l}\text { Willamette } \\
\text { River }\end{array}$ & 04-11-1994 & 1005 & $<2.0$ & $<2.00$ & 86 & 68 & 17 & 1,500 & 1.70 & .60 & 37 & .49 & .30 \\
\hline $\begin{array}{l}\text { Willamette } \\
\text { River }\end{array}$ & 11-03-1994 & 0956 & 3.0 & .30 & 72 & 62 & 33 & 1,900 & .11 & .90 & 38 & .40 & .33 \\
\hline $\begin{array}{l}\text { Willamette } \\
\text { River }\end{array}$ & 11-03-1994 & 1001 & 3.0 & .21 & 74 & 86 & 28 & 1,900 & .11 & .60 & 37 & .40 & .31 \\
\hline \multicolumn{14}{|c|}{ Blind standard-reference sample } \\
\hline SRM GSD-4 & 06-30-1994 & 1200 & 2 & $<2$ & 87 & 36 & 27 & 830 & .05 & .50 & 42 & .2 & .1 \\
\hline MPV & -- & -- & 2.4 & .19 & 81 & 37.3 & 30.4 & 850 & .044 & .86 & 40 & .28 & .084 \\
\hline
\end{tabular}


Table 44. Quality-assurance data for suspended trace element samples, lower Columbia River Basin, Oregon, 1994-Continued

[All values are reported in micrograms per gram, except aluminum, calcium, iron, magnesium, phosphorus, potassium, sodium, and titanium which are in percent; Willamette River, Willamette River at Portland, Oregon; SRM, Standard-Reference Material; --, not analyzed or not applicable; MPV, Most-Probable Value]

\begin{tabular}{|c|c|c|c|c|c|c|c|c|c|c|c|c|c|}
\hline $\begin{array}{c}\text { Sample } \\
\text { description }\end{array}$ & Date & Time & Vanadium & Zinc & Bismuth & Cobalt & Europium & Gallium & Holmium & Lanthanum & Neodymium & Niobium & Scandium \\
\hline \multicolumn{14}{|c|}{ Split samples } \\
\hline $\begin{array}{l}\text { Willamette } \\
\text { River }\end{array}$ & 04-11-1994 & 1000 & 180 & 130 & $<20$ & 27 & $<3.0$ & 20 & $<7.0$ & 30 & 28 & 17 & 23 \\
\hline $\begin{array}{l}\text { Willamette } \\
\text { River }\end{array}$ & 04-11-1994 & 1005 & 180 & 130 & $<20$ & 25 & $<4.0$ & 20 & $<8.0$ & 26 & 27 & 16 & 23 \\
\hline $\begin{array}{l}\text { Willamette } \\
\text { River }\end{array}$ & 11-03-1994 & 0956 & 170 & 120 & $<20$ & 28 & $<4.0$ & 14 & $<8.0$ & 24 & 23 & 10 & 23 \\
\hline $\begin{array}{l}\text { Willamette } \\
\text { River }\end{array}$ & 11-03-1994 & 1001 & 170 & 140 & $<20$ & 29 & $<4.0$ & 17 & $<8.0$ & 26 & 24 & 11 & 22 \\
\hline \multicolumn{14}{|c|}{ Blind standard-reference sample } \\
\hline SRM GSD-4 & 06-30-1994 & 1200 & 120 & 100 & $<20$ & 20 & $<4$ & 19 & $<8$ & 35 & 26 & 15 & 15 \\
\hline MPV & -- & -- & 118 & 101 & .64 & 18 & 1.3 & 20.5 & 1.07 & 40 & 32 & 18 & 15.4 \\
\hline
\end{tabular}

\begin{tabular}{|c|c|c|c|c|c|c|c|c|c|c|c|c|c|}
\hline $\begin{array}{c}\text { Sample } \\
\text { description }\end{array}$ & Date & Time & Strontium & Tantalum & Thorium & Tin & Uranium & Yttrium & Ytterbium & Lithium & Cerium & Gold & Thallium \\
\hline \multicolumn{14}{|c|}{ Split samples } \\
\hline $\begin{array}{l}\text { Willamette } \\
\text { River }\end{array}$ & 04-11-1994 & 1000 & 210 & $<70$ & 8.0 & $<8.0$ & 1.9 & 29 & 3.0 & 29 & 55 & $<10$ & 0.30 \\
\hline $\begin{array}{l}\text { Willamette } \\
\text { River }\end{array}$ & 04-11-1994 & 1005 & 210 & $<80$ & 6.7 & $<10.0$ & 1.8 & 27 & 3.0 & 29 & 52 & $<20$ & .40 \\
\hline $\begin{array}{l}\text { Willamette } \\
\text { River }\end{array}$ & 11-03-1994 & 0956 & 260 & $<80$ & 5.6 & $<10.0$ & 2.1 & 30 & 3.0 & 28 & 46 & $<20$ & .39 \\
\hline $\begin{array}{l}\text { Willamette } \\
\text { River }\end{array}$ & 11-03-1994 & 1001 & 250 & $<80$ & 4.7 & $<10.0$ & 1.9 & 28 & 3.0 & 28 & 45 & $<20$ & .35 \\
\hline \multicolumn{14}{|c|}{ Blind standard-reference sample } \\
\hline SRM GSD-4 & 06-30-1994 & 1200 & 140 & $<80$ & 16.6 & $<10$ & 2.1 & 17 & $<2$ & 53 & 69 & $<20$ & 1.2 \\
\hline MPV & -- & -- & 142 & 1.36 & 14.6 & 4.0 & 2.6 & 26 & 2.9 & 51 & 78 & -- & 1.2 \\
\hline
\end{tabular}


Table 45. Quality-assurance data for organic compounds in filtered water, lower Columbia River Basin, Oregon and Washington, 1994

[The term "filtered water" is an operational definition referring to the chemical analysis of that portion of a water-suspended sediment sample that passes through a nominal 0.70-micrometer filter; a spike mixture was added to all seven field matrix spike samples to increase river-water compound concentrations by $100 \mathrm{ng} / \mathrm{L}$ (nanograms per liter); MDL, method-detection limit; n, number of samples; Min, minimum; Max, maximum; Difference, the difference in concentrations determined for the split sample; Mean, the mean concentration determined for the split sample; see table 9 for Chemical Abstract Services Registry number for each compound; *, both concentrations were found to be below the MDL; \#, values were not calculated because one concentration was found to be below and the other above the MDL; no quality-assurance data exist for acetochlor because it was added into the analytical schedule after the project had started]

\begin{tabular}{|c|c|c|c|c|c|c|c|c|c|c|c|c|}
\hline \multirow{3}{*}{ Compound } & \multirow{3}{*}{$\begin{array}{c}\text { MDL, } \\
\text { in ng/L }\end{array}$} & \multirow{2}{*}{\multicolumn{3}{|c|}{$\begin{array}{l}\text { Field matrix spike } \\
\text { recoveries, in percent } \\
(n, 7)\end{array}$}} & \multicolumn{8}{|c|}{ Split sample concentrations, in ng/L } \\
\hline & & & & & \multicolumn{2}{|c|}{1} & \multicolumn{2}{|l|}{2} & \multicolumn{2}{|l|}{3} & \multicolumn{2}{|l|}{4} \\
\hline & & Min & Median & Max & Difference & Mean & Difference & Mean & Difference & Mean & Difference & Mean \\
\hline Alachlor & 2 & 97 & 120 & 140 & $*$ & $*$ & $*$ & $*$ & $*$ & $*$ & $*$ & $*$ \\
\hline Atrazine & 1 & 97 & 110 & 180 & 1 & 12 & 1 & 46 & $*$ & $*$ & 2 & 2 \\
\hline Azinphos-methyl & 1 & 54 & 130 & 250 & $*$ & $*$ & $*$ & $*$ & $*$ & $*$ & $*$ & $*$ \\
\hline Benfluralin & 2 & 62 & 90 & 100 & $*$ & * & $*$ & $*$ & $*$ & $*$ & $*$ & $*$ \\
\hline Butylate & 2 & 92 & 100 & 120 & $*$ & $*$ & 2 & 6 & $*$ & $*$ & $*$ & $*$ \\
\hline Carbaryl & 3 & 93 & 160 & 170 & $*$ & $*$ & $*$ & $*$ & $*$ & $*$ & $*$ & $*$ \\
\hline Carbofuran & 3 & 76 & 130 & 140 & 58 & 56 & $*$ & $*$ & $*$ & $*$ & $*$ & $*$ \\
\hline Chlorpyrifos & 4 & 90 & 120 & 130 & 2 & 16 & $*$ & $*$ & $*$ & $*$ & $*$ & $*$ \\
\hline Cyanazine & 4 & 86 & 100 & 150 & $*$ & $*$ & $*$ & $*$ & $*$ & $*$ & $*$ & $*$ \\
\hline DCPA (Dacthal) & 2 & 99 & 120 & 130 & $\#^{\mathrm{a}}$ & \# & $*$ & $*$ & $*$ & $*$ & $*$ & $*$ \\
\hline 4,4'-DDE & 6 & 66 & 70 & 77 & $*$ & $*$ & $*$ & $*$ & 1 & 2 & $*$ & $*$ \\
\hline Deethylatrazine & 2 & 30 & 40 & 110 & 6 & 21 & $*$ & $*$ & 5 & 8 & $*$ & $*$ \\
\hline Diazinon & 2 & 80 & 100 & 110 & 1 & 26 & 1 & 6 & 1 & 8 & $*$ & $*$ \\
\hline Dieldrin & 1 & 82 & 100 & 120 & $*$ & $*$ & $*$ & $*$ & 1 & 16 & $*$ & $*$ \\
\hline 2,6-Diethylaniline & 3 & 78 & 90 & 110 & $*$ & $*$ & $*$ & $*$ & $*$ & $*$ & $*$ & $*$ \\
\hline Disulfoton & 17 & 56 & 130 & 230 & $*$ & $*$ & $*$ & $*$ & $*$ & $*$ & $*$ & $*$ \\
\hline EPTC & 2 & 90 & 108 & 120 & 2 & 19 & $*$ & $*$ & $*$ & $*$ & $*$ & $*$ \\
\hline Ethalfluralin & 4 & 75 & 100 & 130 & $*$ & $*$ & $*$ & $*$ & $*$ & $*$ & $*$ & $*$ \\
\hline Ethoprop & 3 & 93 & 120 & 140 & $*$ & $*$ & $*$ & $*$ & $*$ & $*$ & $*$ & $*$ \\
\hline Fonofos & 3 & 85 & 100 & 120 & 2 & 4 & $*$ & $*$ & $*$ & $*$ & $*$ & $*$ \\
\hline alpha-HCH & 2 & 94 & 120 & 130 & $*$ & $*$ & $*$ & $*$ & $*$ & $*$ & $*$ & $*$ \\
\hline gamma-HCH (lindane) & 4 & 86 & 110 & 130 & 4 & 92 & $*$ & $*$ & $\#^{\mathrm{b}}$ & $\#$ & $*$ & $*$ \\
\hline Linuron & 2 & 54 & 90 & 160 & $*$ & $*$ & $*$ & $*$ & $*$ & $*$ & $*$ & $*$ \\
\hline Malathion & 5 & 90 & 110 & 150 & $*$ & * & $*$ & $*$ & $*$ & $*$ & $*$ & $*$ \\
\hline Methyl parathion & 6 & 80 & 130 & 140 & $*$ & $*$ & $*$ & $*$ & $*$ & $*$ & $*$ & $*$ \\
\hline Metolachlor & 2 & 100 & 120 & 130 & 10 & 31 & 2 & 72 & 0 & 190 & 0 & 3 \\
\hline
\end{tabular}


Table 45. Quality-assurance data for organic compounds in filtered water, lower Columbia River Basin, Oregon and Washington, 1994-Continued

[The term "filtered water" is an operational definition referring to the chemical analysis of that portion of a water-suspended sediment sample that passes through a nominal 0.70-micrometer filter; a spike mixture was added to all seven field matrix spike samples to increase river-water compound concentrations by $100 \mathrm{ng} / \mathrm{L}$ (nanograms per liter); MDL, method-detection limit; $\mathrm{n}$, number of samples; Min, minimum; Max, maximum; Difference, the difference in concentrations determined for the split sample; Mean, the mean concentration determined for the split sample; see table 9 for Chemical Abstract Services Registry number for each compound; *, both concentrations were found to be below the MDL; \#, values were not calculated because one concentration was found to be below and the other above the MDL; no quality-assurance data exist for acetochlor because it was added into the analytical schedule after the project had started]

\begin{tabular}{|c|c|c|c|c|c|c|c|c|c|c|c|c|}
\hline \multirow{3}{*}{ Compound } & \multirow{3}{*}{$\begin{array}{c}\text { MDL, } \\
\text { in ng/L }\end{array}$} & \multirow{2}{*}{\multicolumn{3}{|c|}{$\begin{array}{l}\text { Field matrix spike } \\
\text { recoveries, in percent } \\
(\mathrm{n}, 7)\end{array}$}} & \multicolumn{8}{|c|}{ Split sample concentrations, in $\mathrm{ng} / \mathrm{L}$} \\
\hline & & & & & \multicolumn{2}{|l|}{1} & \multicolumn{2}{|l|}{2} & \multicolumn{2}{|l|}{3} & \multicolumn{2}{|l|}{4} \\
\hline & & Min & Median & Max & Difference & Mean & Difference & Mean & Difference & Mean & Difference & Mean \\
\hline Metribuzin & 4 & 82 & 110 & 130 & $*$ & $*$ & $*$ & $*$ & $*$ & $*$ & $*$ & $*$ \\
\hline Molinate & 4 & 97 & 103 & 120 & * & * & $*$ & $*$ & $*$ & $*$ & $*$ & $*$ \\
\hline Napropamide & 3 & 84 & 101 & 140 & 1 & 10 & $*$ & $*$ & 2 & 98 & $*$ & $*$ \\
\hline Parathion & 4 & 85 & 130 & 140 & $*$ & $*$ & $*$ & $*$ & $*$ & $*$ & $*$ & $*$ \\
\hline Pebulate & 4 & 93 & 100 & 120 & $*$ & $*$ & $*$ & $*$ & $*$ & $*$ & $*$ & $*$ \\
\hline Pendimethalin & 4 & 67 & 100 & 120 & $*$ & $*$ & $*$ & $*$ & $*$ & $*$ & $*$ & $*$ \\
\hline cis-Permethrin & 5 & 10 & 20 & 20 & $*$ & $*$ & $*$ & $*$ & $*$ & $*$ & $*$ & $*$ \\
\hline Phorate & 2 & 64 & 90 & 140 & $*$ & $*$ & $*$ & $*$ & $*$ & $*$ & $*$ & $*$ \\
\hline Prometon & 18 & 100 & 110 & 110 & $*$ & $*$ & $*$ & $*$ & 1 & 10 & $*$ & $*$ \\
\hline Pronamide & 3 & 87 & 100 & 120 & * & * & $*$ & * & $*$ & $*$ & $*$ & $*$ \\
\hline Propachlor & 7 & 86 & 120 & 130 & $*$ & $*$ & $*$ & $*$ & $*$ & $*$ & $*$ & $*$ \\
\hline Propanil & 4 & 110 & 120 & 130 & $*$ & $*$ & $*$ & $*$ & $*$ & $*$ & $*$ & $*$ \\
\hline Propargite & 13 & 33 & 110 & 140 & $*$ & $*$ & $*$ & $*$ & $*$ & $*$ & $*$ & $*$ \\
\hline Simazine & 5 & 50 & 101 & 120 & 0 & 1,300 & $*$ & $*$ & 7 & 82 & * & * \\
\hline Tebuthiuron & 10 & $<10$ & 88 & 100 & $*$ & $*$ & $*$ & $*$ & $*$ & $*$ & $*$ & $*$ \\
\hline Terbacil & 7 & 76 & 110 & 140 & $*$ & $*$ & 1 & 20 & 3 & 12 & $*$ & $*$ \\
\hline Terbufos & 13 & 77 & 130 & 160 & $*$ & $*$ & $*$ & $*$ & $*$ & $*$ & $*$ & $*$ \\
\hline Thiobencarb & 2 & 100 & 120 & 130 & $*$ & * & $*$ & $*$ & $*$ & $*$ & $*$ & $*$ \\
\hline Triallate & 1 & 91 & 100 & 120 & $*$ & $*$ & $*$ & $*$ & $*$ & $*$ & $*$ & $*$ \\
\hline Trifluralin & 2 & 66 & 90 & 110 & $*$ & $*$ & $*$ & $*$ & $*$ & $*$ & $*$ & $*$ \\
\hline
\end{tabular}

${ }^{\mathrm{a}}$ For DCPA (Dacthal) split 1, the concentrations determined were $<2$ and $2 \mathrm{ng} / \mathrm{L}$.

${ }^{\mathrm{b}}$ For Lindane split 3 , the concentrations determined were $<4$ and $5 \mathrm{ng} / \mathrm{L}$. 
detection of water-quality trends over time. From the water-resource manager's perspective, ambient monitoring can provide quantitative information that can be used to form the basis for water-quality management decisions that will sustain acceptable levels of water quality. Where water-quality concerns exist, however, ambient monitoring can provide information for evaluating management options, initiating corrective actions, and evaluating effectiveness of actions.

Before considering future data-collection activities, it would be beneficial to summarize and present the relevant technical information gathered by the Bi-State committee to water-resource managers. If all basic water-quality data were stored in one database that is accessible at all levels, including Federal, State, local, Tribal, university, and the general public, the data could be compiled and utilized more efficiently. The data contained in the technical-information summary can be used by water-resource managers to identify water-quality problems and issues affecting beneficial uses in the lower Columbia River Basin. Once water-quality problems and issues have been defined, the following conceptual framework will provide a basis for designing and refining water-quality monitoring programs:

- Develop conceptual models of processes causing water-quality problems. Address specifically processes of input, transport and interaction among media (dissolved, suspended, and aquatic biota)

- Verify conceptual models with existing data; where data are inadequate, supplement ongoing data-collection activities.

- Determine the validity of conceptual models using a mass-balance approach. The conceptual model is verified if loads between main-stem sites balance. If loads fail to balance, however, then unaccountedfor loads (sources) remain and, depending on the magnitude of the unaccounted-for load, the conceptual model goes through further iterations until mass balance is achieved.

- Once mass balance is achieved, design monitoring programs addressing constituents of concern. The monitoring programs should provide more quantitative measures to verify conceptual models, which were refined earlier on the basis of existing water-quality data. Ultimately, monitoring programs can be developed that effectively target and provide data necessary to reduce constituent loadings that previously had resulted in water-quality concerns.

In addition to the conceptual framework presented above, immediate consideration should be given to the following:

- Initiate coordinated interagency qualityassurance/quality-control programs designed to evaluate accuracy, precision, bias, and contamination issues for constituents of concern. Additionally, on the basis of interagency comparisons of various field measurements (for example, $\mathrm{pH}$ and dissolved oxygen—-described in the "Quality Assurance" section), immediate consideration should be given to resolving instrument calibration and (or) measurement techniques that may result in discrepancies between analyzing agencies.

- Supplement the Bi-State database with ancillary data. To increase the utility of the Bi-State database, add ancillary data that are pertinent to water-quality concerns. Ancillary data should include land and water-use information, precipitation quantity and quality, point and nonpoint source waterquality data, and fertilizer and pesticide quantities associated with agricultural activities.

- Continue the collection of monthly suspended sediment data from the Cowlitz River at Kelso. These data and USGS continuous streamflow data from the Cowlitz River at Castle Rock could be used to estimate monthly and annual mean suspended-sediment loads. On the basis of sparse data collected in September 1994, the Cowlitz River accounted for more than 20 percent of the suspended-sediment load in the Columbia River at Beaver Army Terminal. Consequently, better definition of the timing and magnitude of Cowlitz River suspended-sediment loads may provide useful information to water-quality managers as dredging needs are assessed and 
the efficiency of sediment-retention structures is evaluated.

- Synoptically sample selected sites in the lower Columbia River Basin during low streamflows in late summer and again, in late fall or early spring, during periods of storm runoff in the Willamette River Basin. Because sampling dates during the current study were sometimes separated by days and weeks, mass-balance calculations were hampered for periods of storm runoff and were semiqualitative during periods of low streamflow.

- Supplement the Bi-State database with ongoing water-quality measurements made by other agencies. For example, measurements made by the U.S. Army Corps of Engineers for total dissolved gas, dissolved oxygen, water temperature, and barometric pressure in the lower main stem, in addition to pertinent data collected by the National Biological Service, U.S. Fish and Wildlife Service, and National Marine Fisheries Service could be incorporated in the database. Water-quality data from the USGS's NASQAN program at the Columbia River near Beaver Army Terminal and Willamette River at Portland should also be included in the Bi-State database.

As part of the USGS's NASQAN sampling network in the lower Columbia River Basin in 1995, water-quality samples will be collected from the Columbia River at Beaver Army Terminal and the Willamette River at Portland. Each site will be sampled monthly, in addition to six event-based samplings. Data collected as part of the NASQAN program will compliment many of the data collected in the current Bi-State monitoring program.

\section{SUMMARY}

Historically, water-quality studies in the lower Columbia River have focused on specific river reaches; many of these studies lack the continuity necessary to assess water quality in a river-basin framework. The Bi-State study has addressed this data gap by initiating an ambient-monitoring program that will assess temporal variations in constituent concentrations and loads in 1994. The purpose of this report is to describe the water-quality conditions in the lower Columbia River and major tributaries, by interpreting data collected historically and in 1994.

The Columbia River Basin has a drainage area of 259,000 square miles. Its drainage basin crosses seven northwestern States and one Canadian Province. The lower Columbia River Basin, which is the focus of this study, includes the subbasins draining into the Columbia River below Bonneville Dam, the largest of which is the Willamette River.

The lower Columbia River Basin receives mean annual precipitation ranging from 37 inches at Portland, Oregon, to 113 inches at Cougar, Washington. Streamflows in tributaries of the lower Columbia River are generally highest during the winter, but Columbia River streamflows are highest during the spring snowmelt season. The basin is 74 percent forest land and 17 percent agricultural land. Most of the agricultural land lies in the Willamette River Basin, which accounts for 87 percent of the irrigation withdrawals and 55 percent of the industrial withdrawals in the lower Columbia River Basin. On the basis of National Pollutant Discharge Elimination System permits, 102 municipal and industrial sites discharge into the lower Columbia River and the first 16 river miles of its tributaries. More than one-half of these are sewage-treatment plants, chemical manufacture facilities, or wood products industries.

The U.S. Geological Survey (USGS), Washington Department of Ecology, and Oregon Department of Environmental Quality collected water-quality data at 10 sites in the lower Columbia River Basin from January to December of 1994. Additionally, water-quality data spanning more than 50 years and more than 200 parameters were collated for interpretation in this report. Loads of suspended sediment, total dissolved solids, unfiltered-water phosphorus and filtered-water nitrite plus nitrate and ammonia were calculated by regressing constituent concentrations against streamflow and time. Monotonic-time trends were determined for water temperature, suspended sediment, unfiltered phosphorus, specific conductance, and total dissolved solids. Nutrient, major-ion, trace-element, and organic-compound concentrations were screened against U.S. Environmental Protection Agency (EPA) and State guidelines. Physical and micro- 
biological measurements also were screened against State guidelines.

On the basis of an analysis of historical watertemperature data, percentile distributions of daily mean water temperatures were generally uniform among sites in the main stem of the lower Columbia River. An earlier USGS study notes that the principal water-temperature increases were measured well upstream of the lower Columbia River, in an area between Grand Coulee Dam and McNary Dam. Historical data also show that the temperature gradient is small between the Willamette River and the main stem of the Columbia River. Both historical and current data show that the highest water temperatures in the lower Columbia River Basin are during August. In the Columbia River at Bradwood, 75 percent of the daily mean water temperatures exceeded $20^{\circ} \mathrm{C}$, a "special condition" criterion for the State of Washington. In 1994, 15 percent of the instantaneous measurements of water temperature exceeded $20^{\circ} \mathrm{C}$ in the lower Columbia River. The special condition criterion was exceeded consistently at the four main-stem sites during July and August - a period coinciding with season-high air temperatures and low streamflows.

Dissolved-oxygen concentrations vary in accordance with seasonal changes in water temperature. Aquatic life in the lower Columbia River Basin is not subjected to low dissolvedoxygen concentrations. Only the Sandy River at Troutdale had a dissolved-oxygen concentration below the Oregon State standard of 90 percent of saturation. Although concentrations of dissolved oxygen at the Willamette River and Multnomah Channel sites were lower than at other sites in the basin, they did not fall below the Oregon State standard of $5 \mathrm{mg} / \mathrm{L}$. These decreases in concentration probably resulted from biochemicaloxygen demand. Comparison of dissolved-oxygen concentrations in the Willamette River from before 1958 to after 1972 showed a significant increase in dissolved-oxygen concentrations during the lowstreamflow months of summer. Concentrations of dissolved oxygen and total dissolved gas were above saturation levels during high streamflows in the Willamette River and the lower Columbia River. The high concentrations of total dissolved gas in the Columbia River exceeded Oregon and Washington State standards of 110 percent of saturation and were caused by spilling water at the Columbia River dams.

Suspended-sediment and suspended-solid concentrations tend to increase with increased streamflow but were generally very low (less than 15 $\mathrm{mg} / \mathrm{L}$ ) during most of the year. Among sites, the Willamette River generally had higher concentrations. There were no detectable long-term trends in suspended sediment at the Willamette River and Columbia River at Warrendale sites. Suspended-sediment loads at the Beaver Army Terminal site in June and July of 1994 were larger than could be accounted for on the basis of loads measured upstream at the Warrendale and Willamette River sites. The difference in load between sites probably results from suspended sediment that is stored upstream of the Beaver site during low-streamflow conditions on the Columbia River and then resuspended during the high streamflows of the snowmelt season. Load calculations also showed that the Cowlitz River can be a source of sediment during high flows, whereas other tributaries do not appear to be significant sources.

Historical data and data for 1994 indicated that nutrients have relatively low concentrations in the lower Columbia River Basin. Historically, the largest 90th-percentile concentrations of unfiltered-water phosphorus and filtered-water nitrite plus nitrate and ammonia in the basin were in the Willamette River Basin. When 1994 median concentrations were ranked from largest to smallest for unfiltered-water phosphorus and filtered-water orthophosphate and nitrite plus nitrate, sampling sites followed the order:

Willamette River > Multnomah Channel > Columbia River sites downstream of Willamette River $>$ Columbia River sites upstream of Willamette River > smaller tributaries.

Concentrations of unfiltered-water phosphorus in the Willamette River were largest during periods of winter storms from October to February 1994. Trend tests showed a significant $(\rho<0.05)$ downward trend for unfiltered-water phosphorus at the Columbia River at Warrendale from 1973 to 1994. Nutrient loads during 1994 in the Willamette River and Columbia River were comparable to those in the low-streamflow year of 1977, which is consistent with the low precipitation and streamflow in 1994. The Willamette River made a significant 
contribution to the loading of filtered-water nitrite plus nitrate and unfiltered-water phosphorus in the Columbia River. In May, the Willamette River contributed 25 percent of the measured nitrite-plusnitrate load to the Columbia River, while contributing only 6 percent of the streamflow. In August, the Willamette River contributed 16 percent of the phosphorus load to the Columbia River, while contributing only 8 percent of the streamflow.

Median concentrations of most major ions in the lower Columbia River Basin in 1994 were similar to mean concentrations measured in river systems worldwide. In comparison to historical data, however, concentrations of major ions measured in 1994 were lower than historical measurements and reflect the limited dilution capacity of the main stem-a result of the low streamflows in 1994. On the basis of instantaneous measurements of specific conductance, median conductance values among main-stem sites were generally constant, ranging from 149 to $153 \mu \mathrm{S} / \mathrm{cm}$. During the fall months, however, a specificconductance gradient was measured among mainstem sites, decreasing by $37 \mu \mathrm{S} / \mathrm{cm}$ from Warrendale to Beaver Army Terminal, an effect of the lower specific conductance of water in the Willamette River and seasonally higher streamflows entering the main stem from the Willamette River. The median specific conductance in the Willamette River was $79 \mu \mathrm{S} / \mathrm{cm}$, nearly one-half that of the main stem. The lower conductance waters of the Willamette River result from lower calcium, magnesium, and bicarbonate concentrations. Majorion composition along the main stem remained relatively unchanged, with calcium and magnesium as the dominant cations and bicarbonate as the dominant anion.

Median concentrations of trace elements measured in 1994 were similar to background concentrations measured worldwide. The concentrations were also similar to historical concentrations, except for iron, which in 1994 had a median concentration $(25 \mu \mathrm{g} / \mathrm{L})$, about one-half that measured historically. This difference is the result of a disproportionately high number of sites sampled historically in the Willamette River Basin. Arsenic, a human carcinogen, was detected in 15 of 16 samples in the main stem, but was not detected in the tributary sites. All 15 arsenic detections had concentrations that exceeded EPA ambient water- quality criteria for the protection of human health and EPA human-health advisories for drinking water. Chromium was detected in all four main-stem sites, and most frequently, in the Columbia River at Hayden Island. None of the concentrations detected, however, exceeded water-quality criteria or guidelines.

Measurements of suspended trace-element concentrations (trace-element concentrations associated with the suspended-sediment fraction) showed that the suspended form is the dominant transport phase for aluminum, iron, and manganese, whereas the dissolved form is the dominant transport phase for arsenic, barium, chromium, and copper. Because seasonal variations in suspended traceelement concentrations are low, suspended traceelement loads are affected primarily by variations in suspended-sediment concentration. Consequently, winter storm-induced high streamflows have considerably greater loads than low streamflows, which are characteristic of summer and early fall. During periods of low streamflow, the Willamette River and Cowlitz River are the largest contributors of suspended trace-elements in the Basin. During the low-streamflow period, the Willamette River represents 60 percent of the suspended-silver load in the Columbia River at Warrendale, whereas only 10 percent of the streamflow is represented. On the basis of tributary loads during summer low-flow months, sources of suspended silver, nickel, aluminum, and antimony exist in the lower Columbia Basin and the sources of suspended zinc and arsenic exist outside of the lower basin.

Of the 47 organic compounds analyzed for this study, only 20 were detected. The Willamette River at Portland had the largest number of detections, and all 20 were detected at one time or another at that site. None of the organic compounds measured exceeded EPA's ambient water-quality criteria or drinking-water guidelines. Atrazine, metolachlor, and simazine were the three most frequently detected organic compounds in the lower Columbia River Basin. These pesticides all come from agricultural sources. The largest concentrations of atrazine, metolachlor, and simazine were detected in the Willamette River, where they were detected in 85 to 90 percent of the samples collected. The high concentrations of atrazine in the Willamette River are associated with the spring application period and 
fall runoff and can be seen to affect atrazine concentrations in the main stem and Multnomah Channel. These seasonal variations are noticeable also with simazine and metolachlor. The Willamette River is unquestionably the single largest source of atrazine to the lower Columbia River.

Fecal-indicator bacteria measurements exceeded the Washington State standard for fecal coliform in one instance, in the Cowlitz River. Additionally, the Washington State standard was exceeded for several different fecal-indicator bacteria and in multiple samples in the Willamette River and Columbia River at Beaver Army Terminal. Other sites sampled generally had low concentrations. A review of historical data also showed consistently low concentrations in the Columbia River at Warrendale, with higher and more variable concentrations in the Willamette River. The source of bacteria in the Willamette River is likely local runoff from the Portland urban area.

\section{REFERENCES CITED}

American Public Health Association, American Public Water Works Association, and Water Pollution Control Federation, 1989, Standard methods for the examination of water and wastewater (17th ed.): Washington, D.C., American Public Health Association, 1527 p.

1992, Standard methods for the examination of water and wastewater (18th ed.): Washington, D.C., American Public Health Association, [variously paged].

Anderson, J.R., Hardy, E.E., Roach, J.T., and Witmer, R.E., 1976, A land use and land cover classification system for use with remote sensor data: U.S. Geological Survey Professional Paper 964, 28 p.

Bjornn, T.C. and Reiser, D.W., 1991, Habitat requirements of salmonids in streams: American Fisheries Society Special Publication 19, p. 83-138.

Briggs, P.H., 1990, Elemental analysis of geological materials by inductively coupled plasma-atomic emission spectrometry, in Arbogast, B.F., ed., Quality assurance manual for the Branch of Geochemistry: U.S. Geological Survey Open-File Report 90-668, p. 8391.

Britton, L.J., and Greeson, P.E., 1987, Methods for collection and analysis of aquatic biological and microbiological samples: U. S. Geological Survey Techniques of Water-Resources Investigations, book 5, chap. A4, 363 p.
Brenton, R.W., and Arnett, T.L., 1993, Methods of analysis by the U.S. Geological Survey National Water Quality Laboratory-Determination of dissolved organic carbon by UV-promoted persulfate oxidation and infrared spectrometry: U.S. Geological Survey OpenFile Report 92-480, 12 p.

Burrill, L.C., William, R.D., Parker, R., Boerboom, C., Callihan, R.H., Eberlein, C., and Morishita, D.W., 1992, Pacific northwest weed control handbook: Extension Services of Oregon State University, Washington State University, and University of Idaho, $326 \mathrm{p}$.

Cohn, T.A., DeLong, L.L., Gilroy, E.J., Hirsch, R.M., and Wells, D.K., 1989, Estimating constituent loads: Water Resources Research, v. 25, no. 5, p. 937-942.

Cohn, T.A., Caulder, D.L., Gilroy, E.J., Zynjuk, L.D., and Summers, R.M., 1992, The validity of a simple statistical model for estimating fluvial constituent loads-An empirical study involving nutrient loads entering Chesapeake Bay: Water Resources Research, v. 28, no. 9, p. 2353-2363.

Cohn, T.A., Gilroy, E.J., and Baier, W.G., 1992, Estimating fluvial transport of trace constituents using a regression model with data subject to censoring: Boston,

Proceedings of the Joint Statistical Meeting, August 913, 1992, p. 142-151.

Columbia River Water Management Group, 1994, Columbia River water management report for water year 1993: Portland, Oregon, Columbia River Water Management Group, 142 p.

Crock, J.G., and Lichte, F.E., 1982, An improved method for the determination of trace-level arsenic and antimony in geological materials by automated hydride generationatomic absorption spectroscopy: Analytica Chimica Acta 144, p. 223-233.

Earth-Info, Inc., 1993, Earth-info's NCDC summary of the day (climatological data on CD-ROM): Boulder, Colorado, EarthInfo, Inc.

Edwards, T.K., and Glysson, D.G., 1988, Field methods for measurement of fluvial sediment: U.S. Geological Survey Open-File Report 86-531, 118 p.

Eisler, R., 1988, Arsenic hazards to fish, wildlife, and invertebrates-A synoptic review: U.S. Fish and Wildlife Service Contaminant Hazard Reviews, no. 12, $92 \mathrm{p}$.

Fair, G. M., and Geyer, J. C., 1954, Water supply and wastewater disposal: New York, John Wiley and Sons, Inc., $973 \mathrm{p}$.

Faires, L.M., 1993, Methods of analysis by the U.S. Geological Survey National Water-Quality LaboratoryDetermination of metals in water by inductively coupled plasma-mass spectrometry: U.S. Geological Survey Open-File Report 92-634, 28 p. 
Fishman, M.J., ed., 1993, Methods of analysis by the U.S. Geological Survey National Water Quality Laboratory--Determination of inorganic and organic constituents in water and fluvial sediments: U.S. Geological Survey Open-File Report 93-125, 217 p.

Fishman, M.J., and Friedman, L.C., 1989, Methods for the determination of inorganic substances in water and fluvial sediments ( $3 \mathrm{~d}$ ed.): U. S. Geological Survey Techniques of Water-Resources Investigations, book 5, chap. A1, 545 p.

Forstner, U., and Wittmann, G.T.W., 1979, Metal pollution in the aquatic environment: New York, Springer-Verlag, $486 \mathrm{p}$.

Fuhrer, G.J., Cain, D.J., McKenzie, S.W., Rinella, J.F., Crawford, J. K., Skach, K.A., and Hornberger, M.I., in press, Surface-water-quality assessment of the Yakima River Basin in Washington-Spatial and temporal distribution of trace elements in water, sediment, and aquatic biota, 1987-91: U.S. Geological Survey OpenFile Report 95-440,

Govindaraju, K., ed., 1994, Appendix 1. Reference samples: Geostandards Newsletter, v. 18, p. 17.

Guy, H.P., 1969, Laboratory theory and methods for sediment analysis: U.S. Geological Survey Techniques of Water-Resources Investigations, book 5, chap. C1, $58 \mathrm{p}$.

Helsel, D.R., and Hirsch, R.M., 1992, Statistical methods in water resources: New York, Elsevier, 552 p.

Hem, J.D., 1989, Study and interpretation of the chemical characteristics of natural water ( $3 \mathrm{~d}$ ed.): U.S. Geological Survey Water-Supply Paper 2254, 263 p.

Hirsch, R.M., Slack, J.R., and Smith, R.A., 1982, Techniques of trend analysis for monthly water-quality data: Water Resources Research, v. 18, no. 1, p. 107-121.

Horowitz, A.J., Demas, C.R., Fitzgerald, K.K., Miller, T.L., and Rickert, D.A., 1994, U.S. Geological Survey protocol for the collection and processing of surfacewater samples for the subsequent determination of inorganic constituents in filtered water: U.S. Geological Survey Open-File Report 94-539, 57 p.

Jenne, E.A., and Luoma, S.N., 1977, Forms of trace elements in soils, sediments, and associated waters-An overview of their determination and biological availability, in Biological implications of metals in the environment: Springfield, Virginia, National Technical Information Service, CONF-750929, p. 110-143.

Leahy, P.P., and Thompson, T.H., 1994, U.S. Geological Survey National Water-Quality Assessment program: U.S. Geological Survey Open-File Report 94-70, p. 4.

Long, K.H. and Farrar, J.W., 1995, Report on the U.S. Geological Survey's evaluation program for standard reference samples distributed in October 1994-T-131 (trace constituents), T-133 (trace constituents), M-132 (major constituents), N-43 (nutrients), N-44 (nutrients), P-23 (low ionic strength) and Hg-19 (mercury): U.S. Geological Survey Open-File Report 95-117, $139 \mathrm{p}$.

Luoma, S.N., 1983, Bioavailability of trace metals to aquatic organisms - a review: Science of the Total

Environment, v. 28, p. 1-22.

1989 , Can we determine the biological availability of sediment-bound trace elements?: Hydrobiologia, v. 176/177, p. 379-396.

MacDonald, L. H., Smart, A.W., and Wissmar, R.C., 1991, Monitoring guidelines to evaluate effects of forestry activities on streams in the Pacific Northwest and Alaska: U.S. Environmental Protection Agency, EPA910/9-91-001, 166 p.

Meade, R.H., and Stevens, H.H., Jr., 1990, Strategies and equipment for sampling suspended sediment and associated toxic chemicals in large rivers-With emphasis on the Mississippi River: The Science of the Total Environment, v. 97/98, p. 125-135.

Mercer, J.W., Skipp, D.C., and Giffin, Daniel, 1990, Basics of pump-and-treat ground-water remediation technology: U.S. Environmental Protection Agency, EPA 600/890/003, 31 p.

Moffatt, R.L., Wellman, R.E., and Gordon, J.M., 1990, Monthly and annual streamflow and flow-duration values, v. 2 of Statistical summaries of streamflow data in Oregon: U.S. Geological Survey Open-File Report 90-118, p. 292.

Moore, A. M., 1968, Water temperatures in the Columbia River Basin, July 1966 to September 1967: U. S. Geological Survey Open-File Report, 39 p.

Moore, J.W., 1991, Inorganic contaminants of surface waterResearch and monitoring priorities: New York, Springer-Verlag, 334 p.

Morris, Z. and Mitchell, J.W., 1976, Contamination control in trace element analysis: New York, John Wiley and Sons, $262 \mathrm{p}$.

National Marine Fisheries Service, 1994, Panel on gas bubble disease: Seattle, Washington, Northwest Fisheries Science Center, p. 8.

Nowell, L.H., and Resek, E.A., 1994, Summary of national standards and guidelines for pesticides in water, bed sediment, and aquatic organisms and their application to water-quality assessments: U.S. Geological Survey Open-File Report 94-44, 115 p.

O'Leary, R.M., Crock, J.G., and Kennedy, K.R., 1990, Determination of mercury in geological materials by continuous flow-cold vapor-atomic absorption spectrophotometry, in Arbogast, B.F. ed., Quality assurance manual for the Branch of Geochemistry: U.S. Geological Survey Open-File Report 90-668, p. 60-67.

Oregon Climate Service, 1994, Oregon weather summary (Internet data retrieval): Corvallis, Oregon State University, Department of Atmospheric Sciences. 
Oregon Health Division, 1994a, Environmental radiological surveillance report on Oregon Surface Waters, 19611993, Volume I: Portland, Oregon, Radiation Protection Services, 35 p.

Oregon Health Division, 1994b, Environmental radiological surveillance report on Oregon Surface Waters, 19611993, Volume II: Portland, Oregon, Radiation Protection Services, [unpaged].

Orem, H.M., 1968, Discharge in the lower Columbia River Basin, 1928-65: U.S. Geological Survey Circular 550, $24 \mathrm{p}$.

Patton, C.J., and Truitt, E.P., 1992, Methods of analysis by the U.S. Geological Survey National Water Quality Laboratory-Determination of total phosphorus by a Kjeldahl digestion method and an automated colorimetric finish that includes dialysis: U.S. Geological Survey Open-File Report 92-146, 39 p.

Rickert, D.A., Hines, W.G., and McKenzie, S.W., 1976, Methodology for river-quality assessment with application to the Willamette River Basin, Oregon: U.S. Geological Survey Circular 715-M, 55 p.

Rinella, J.F., McKenzie, S.W., and Fuhrer, G.J., 1992, Surface-water-quality assessment of the Yakima River Basin, Washington-Analysis of available waterquality data through 1985 water year: U.S. Geological Survey Open-File Report 91-453, 244 p.

Saboe, C.W., 1991, "The Big Five"-Some facts and figures on our Nation's largest rivers: U.S. Geological Survey General Interest Publication 1991-303-137, 23 p.

Sherman, J.O., 1976, Reservoir-system model for the Willamette River Basin, Oregon: U.S. Geological Survey Circular 715-H, 22 p.

Smith, R.A., Hirsch, R.M., and Slack, D.R., 1982, A study of trends in total phosphorus measurements at NASQAN stations: U.S. Geological Survey Water-Supply Paper 2190, 34 p.

Smith, R.A., Alexander, R.B., and Wolman, M.G., 1987, Analysis and interpretation of water-quality trends in major U.S. rivers, 1974-81: U.S. Geological Survey Water-Supply Paper 2307, $25 \mathrm{p}$.

Squillace, P.J., and Thurman, E.M., 1992, Herbicide transport in rivers-Importance of hydrology and geochemistry in nonpoint-source contamination: Environmental Science and Technology, v. 26, no. 3, p. 538-545.

State of Oregon, 1994, Regulations relating to water quality control: Oregon Department of Environmental Quality Administrative Rules, chap. 34, [variously paged].

Stober, Q.J., and Nakatani, R.E., 1992, Water quality and biota of the Columbia River system, in Becker, C.D., and Neitzel, D.A, eds., Water quality in North American river systems: Columbus, Ohio, Battelle Press, 304 p.

Tetra Tech, Inc., 1992, Reconnaissance survey of the Lower Columbia River-Task 2 data analysis report-Inventory and characterization of pollutants; prepared for the Lower Columbia River Bi-State Program: Redmond, Washington, TC 8526-02, 198 p.

Tetra Tech, Inc., 1993, Reconnaissance survey of the Lower Columbia River-Task 6 reconnaissance report; prepared for the Lower Columbia River Bi-State Program: Redmond, Washington, TC 8526-06. [variously paged].

Tetra Tech, Inc., 1994, Lower Columbia River backwater reconnaissance survey-v. 1-Reconnaissance report; prepared for the Lower Columbia River Bi-State Program: Redmond, Washington, Draft Report No. TC 9497-06, 430 p.

Thurman, E.M., 1985, Organic geochemistry of natural waters: Dordrecht, The Netherlands, Martinus Nijhoff/Dr. W. Junk Publishers, 497 p.

U.S. Army Corps of Engineers, May 1989, Willamette River basin reservoir system operation, Portland District: Portland, Oregon, 43 p.

1994, 1994 Dissolved gas monitoring for Columbia and Snake Rivers: Portland, Oregon, North Pacific Division, variously paged.

U.S. Environmental Protection Agency, 1976, Quality criteria for water: EPA 440/9-76-023, 501 p.

1979, Methods for chemical analysis of water and wastes: National Environmental Research Center, EPA-600/4-79-020, [variously paged].

1986a, Quality criteria for water: EPA-440/5-86-001, [variously paged].

1986b, Ambient water-quality criteria for bacteria1986: EPA-440/5-84-002, 18 p.

1989, Human health evaluation manual, v. 1 of Risk assessment guidance for superfund: EPA/540/1-89/ 002, [variously paged].

1991, Is your drinking water safe?: Office of Drinking Water, EPA 570/9-91-005, 24 p.

1992a, Interim guidance on interpretation and implementation of aquatic life criteria for metals:

Washington, D.C., Office of Science and Technology, May 1992, 24 p.

1992b, Rules and Regulations: Federal Register, v. 57, no. 246 , p. 60887.

1993a, Fish sampling and analysis-Guidance for assessing chemical contamination data for use in fish advisories: Office of Science and Technology, Fish Contamination Section, v. 1, 351 p.

1993b, Drinking water criteria document on arsenic: Human Risk Assessment Branch, Health and Ecological Criteria Division, EPA Contract No. 68C8-0033, draft.

1994a, ARC/INFO coverages derived from U. S. Geological Survey land use and land cover digital data (Internet retrieval): Washington, D.C., scale 1:250,000 1994b, Drinking water regulations and health advisories: Washington, D.C., Office of Water, November 1994, 11 p. 
1995, 304(a) Criteria chart (toxic substance spreadsheet): Region IV Water Management Division, January 1995, 13 p.

U.S. Geological Survey, 1972-75, Water resources data, Oregon, water years 1971-74_pt. 1, Surface water records: U.S. Geological Survey Water-Data Reports OR-71-1 to OR-74-1 (published annually).

1976-80, Water resources data, Oregon, water years 1975-79, v. 1: U.S. Geological Survey Water-Data Reports OR-75-1 to OR-79-1 (published annually).

-1981, River basins of the United States-The Columbia: U.S. Geological Survey Popular Publication 1981-341-618:53, 9 p.

1981-84, Water resources data, Oregon, water years 1980-83-v. 2, Western Oregon: U.S. Geological Survey Water-Data Reports OR-80-2 to OR-83-2 (published annually).

1982, A U.S. Geological Survey data standardCodes for the identification of hydrologic units in the United States and the Caribbean outlying areas: U.S. Geological Survey Circular 878-A, 115 p.

1995, Water resources data, Oregon, water year 1994: U.S. Geological Survey Water-Data Report OR-94-1, $473 \mathrm{p}$.

Valderrama, J.C., 1981, Simultaneous analysis of total phosphorus and total nitrogen in natural waters: Marine Chemistry, v. 10, p. 109-122.

Warner, K., Lafore, B., and Anderson, R., 1992, Portland/ Vancouver toxic waters: Portland, Oregon, ColumbiaWillamette Riverwatch, pamphlet.
Washington Department of Ecology, 1993, Bacteria study November-December 1992; prepared for the Lower Columbia River Bi-state Program: Olympia, Washington Department of Ecology, 38 p.

Washington State Administrative Code, November 25, 1992 , Chapter 173-201A, 14 p.

Welsch, E.P., Crock, J.G., and Sanzolone, R., 1990, Tracelevel determination of arsenic and selenium using continuous-flow hydride generation atomic absorption spectrophotometry, in Arbogast, B.F., ed., Quality assurance manual for the Branch of Geochemistry: U.S. Geological Survey Open-File Report 90-668, p. 38-45.

Wershaw, R.L., Fishman, M.J., Grabbe, R.R., and Lowe, L.E., eds., 1987, Methods for the determination of organic substances in water and fluvial sediments: U.S. Geological Survey Techniques of Water-Resources Investigations, book 5, chap. A3, 80 p.

Wilhelms, S.C., and Gulliver, J.S., 1994, Self-aerated flow of Corps of Engineers spillways: Vicksburg, Mississippi, U.S. Army Corps of Engineer Waterways Experiment Station, Technical Report W-94-2, p. 103.

Zaugg, S. D., Sandstrom, M. W., Smith, S. G., and Fehlberg, K. M., 1995, Methods of analysis by the U. S. Geological Survey National Water-Quality Laboratory-Determination of pesticides in water by C-18 solid-phase extraction and capillary-column gas chromatography/mass spectrometry with selected-ion monitoring: U. S. Geological Survey Open-File Report 95-181, 79 p.

Zeif, M., Mitchell, James W., 1976, Contamination control in trace element analysis: New York, John Wiley and Sons, 262 p. 


\section{SUPPLEMENTAL DATA SECTION}


Table 46. Point-source locations and National Pollutant Discharge Elimination System permit levels of effluent discharge, lower Columbia River Basin, Oregon and Washington, 1994

[Effluent discharge levels are reported in million gallons per day; STP, sewage-treatment plant; --, not applicable; *, value is based on average dry-weather design flow to facility; WTP, water-treatment plant; NA, data is not known or not shown on permit; \#1 indicates outfall number; Stormwater, discharge is stormwater, therefore no discharge limits are in effect; avg, average; max, maximum; Industrial, permittee is classified as industrial and, therefore, has limits only on concentrations, not discharge; Misc, miscellaneous; UST, underground storage tank; PAH, polyaromatic hydrocarbons; Ref., references are: A $=$ Tetra Tech, Inc., 1992,

B = Tim Hilliard, Washington Department of Ecology, unpub. data, 1995,

C = Debra Nesbit, Oregon Department of Environmental Quality, written commun., 1995,

$\mathrm{D}=$ Drew Gilken, Oregon Steel Mills, Inc., oral commun., 1995]

\begin{tabular}{|c|c|c|c|c|c|c|c|c|c|}
\hline Point-source name & Ref. & $\begin{array}{l}\text { Latitude/ } \\
\text { longitude }\end{array}$ & $\begin{array}{l}\text { Columbia } \\
\text { river mile }\end{array}$ & Receiving water body & $\begin{array}{l}\text { Tributary } \\
\text { river mile }\end{array}$ & $\begin{array}{c}\text { Source } \\
\text { classification }\end{array}$ & $\begin{array}{c}\text { Effluent } \\
\text { discharge level }\end{array}$ & Time unit & Constituents of concern \\
\hline Astoria STP & $\mathrm{A}$ & $\begin{array}{l}461214 / \\
1234621\end{array}$ & 18 & Columbia River & -- & Domestic & 4 & $*$ & \\
\hline Camas STP & B & $\begin{array}{l}453444 / \\
1222317\end{array}$ & 121.2 & Columbia River & -- & Domestic & 2.33 & monthly average & \\
\hline Camas WTP & B & $\begin{array}{l}453618 / \\
1222423\end{array}$ & 118.1 & Lacamas Lake & NA & Domestic & .07 & monthly average & \\
\hline Castle Rock STP & B & $\begin{array}{l}461602 / \\
1225415\end{array}$ & 68 & Cowlitz River & NA & Domestic & .4 & monthly average & \\
\hline Cathlamet STP & B & $\begin{array}{l}461220 / \\
1232315\end{array}$ & NA & Columbia River & -- & Domestic & .2 & monthly average & \\
\hline Cathlamet WTP & B & $\begin{array}{l}461313 / \\
1232110\end{array}$ & NA & Columbia River & -- & Domestic & .049 & monthly average & \\
\hline $\begin{array}{l}\text { Clark Public Utilities } \\
\text { District (La Center } \\
\text { STP) }\end{array}$ & B & $\begin{array}{l}455137 / \\
1224007\end{array}$ & 87 & $\begin{array}{l}\text { East Fork } \\
\text { of Lewis River }\end{array}$ & NA & Domestic & .125 & monthly average & \\
\hline Clatskanie STP & $\mathrm{C}$ & $\begin{array}{l}460718 / \\
1231252\end{array}$ & 47.8 & Clatskanie River & 1.1 & Domestic & .50 & $*$ & \\
\hline $\begin{array}{l}\text { Cowlitz County } \\
\text { Hall of Justice }\end{array}$ & B & $\begin{array}{l}460807 / \\
1225413\end{array}$ & 68 & Cowlitz River & NA & Domestic & .4999 & $\begin{array}{l}\text { weekly } \\
\text { maximum }\end{array}$ & \\
\hline $\begin{array}{l}\text { Cowlitz Water } \\
\text { Pollution Control STP }\end{array}$ & B & $\begin{array}{l}460547 / \\
1225555\end{array}$ & 67 & Columbia River & -- & Domestic & 10 & $*$ & \\
\hline $\begin{array}{l}\text { Fort Columbia State } \\
\text { Park STP }\end{array}$ & B & $\begin{array}{l}461503 / \\
1235518\end{array}$ & 8 & Columbia River & -- & Domestic & .005 & monthly average & \\
\hline Gresham STP & A & $\begin{array}{l}453326 / \\
1222730\end{array}$ & 117.5 & Columbia River & -- & Domestic & 10 & $*$ & \\
\hline Ilwaco STP & B & $\begin{array}{l}461819 / \\
1240158\end{array}$ & 3 & $\begin{array}{l}\text { Columbia River/ } \\
\text { Baker Bay }\end{array}$ & -- & Domestic & .45 & monthly average & \\
\hline Ilwaco WTP & B & $\begin{array}{l}461853 / \\
1240211\end{array}$ & NA & Black Lake & NA & Domestic & .045 & monthly average & \\
\hline
\end{tabular}


Table 46. Point-source locations and National Pollutant Discharge Elimination System permit levels of effluent discharge, lower Columbia River Basin, Oregon and Washington, 1994-Continued

[Effluent discharge levels are reported in million gallons per day; STP, sewage-treatment plant; --, not applicable; *, value is based on average dry-weather design flow to facility; WTP, water-treatment plant; NA, data is not known or not shown on permit; \#1 indicates outfall number; Stormwater, discharge is stormwater, therefore no discharge limits are in effect; avg, average; max, maximum; Industrial, permittee

is classified as industrial and, therefore, has limits only on concentrations, not discharge; Misc, miscellaneous; UST, underground storage tank; PAH, polyaromatic hydrocarbons; Ref., references are: A $=$ Tetra Tech, Inc., 1992,

B = Tim Hilliard, Washington Department of Ecology, unpub. data, 1995,

C = Debra Nesbit, Oregon Department of Environmental Quality, written commun., 1995,

D = Drew Gilken, Oregon Steel Mills, Inc., oral commun., 1995]

\begin{tabular}{|c|c|c|c|c|c|c|c|c|c|}
\hline Point-source name & Ref. & $\begin{array}{l}\text { Latitude/ } \\
\text { longitude }\end{array}$ & $\begin{array}{l}\text { Columbia } \\
\text { river mile }\end{array}$ & Receiving water body & $\begin{array}{l}\text { Tributary } \\
\text { river mile }\end{array}$ & $\begin{array}{c}\text { Source } \\
\text { classification }\end{array}$ & $\begin{array}{c}\text { Effluent } \\
\text { discharge level }\end{array}$ & Time unit & Constituents of concern \\
\hline Kalama STP & B & $\begin{array}{l}460032 / \\
1225042\end{array}$ & 75.5 & Columbia River & -- & Domestic & 0.4 & monthly average & \\
\hline Kellogg Creek STP & $\mathrm{C}$ & $\begin{array}{l}462625 / \\
1223828\end{array}$ & 101.5 & Willamette River & 18.5 & Domestic & 10 & $*$ & \\
\hline Longview STP & B & $\begin{array}{l}461049 / \\
1230045\end{array}$ & 56.4 & Coal Creek Slough & NA & Domestic & 2.7 & monthly average & \\
\hline Longview WTP & B & $\begin{array}{l}460856 / \\
1225447\end{array}$ & 68 & Cowlitz River & NA & Domestic & .13 & monthly average & \\
\hline North Bonneville STP & B & $\begin{array}{l}453749 / \\
1215811\end{array}$ & 145 & Columbia River & -- & Domestic & .1225 & monthly average & \\
\hline $\begin{array}{l}\text { Oak Lodge Sanitary } \\
\text { District }\end{array}$ & $\mathrm{C}$ & $\begin{array}{l}452530 / \\
1223910\end{array}$ & 101.5 & Willamette River & 20.1 & Domestic & 4 & $*$ & \\
\hline $\begin{array}{l}\text { Portland STP } \\
\text { (Columbia Boulevard) }\end{array}$ & $\mathrm{C}$ & $\begin{array}{l}453726 / \\
1224132\end{array}$ & 105.5 & Columbia River & -- & Domestic & $\begin{array}{l}\# 1: 100 \\
\# 2: 100\end{array}$ & * & \\
\hline $\begin{array}{l}\text { Portland Tryon Creek } \\
\text { STP }\end{array}$ & $\mathrm{C}$ & $\begin{array}{l}452500 / \\
1223945\end{array}$ & 101.5 & Willamette River & 19.0 & Domestic & 8.3 & $*$ & \\
\hline Rainier STP & A & $\begin{array}{l}460537 / \\
1225642\end{array}$ & 67 & Columbia River & -- & Domestic & .5 & $*$ & \\
\hline Ridgefield STP & B & $\begin{array}{l}474915 / \\
1224507\end{array}$ & 87.5 & Lake River & NA & Domestic & .35 & monthly average & \\
\hline $\begin{array}{l}\text { Riverwood Mobile } \\
\text { Home Park }\end{array}$ & A & $\begin{array}{l}460403 / \\
1225349\end{array}$ & 70.6 & Columbia River & -- & Domestic & .013 & $*$ & \\
\hline St. Helens STP & A & $\begin{array}{l}455116 / \\
1224714\end{array}$ & 86 & Columbia River & -- & Domestic & NA & -- & $\begin{array}{l}\text { halogenated organic } \\
\text { compounds }\end{array}$ \\
\hline $\begin{array}{l}\text { Salmon Creek STP } \\
\text { (Clark County) }\end{array}$ & B & $\begin{array}{l}454239 / \\
1224530\end{array}$ & 97.2 & Columbia River & -- & Domestic & 3.1 & monthly average & \\
\hline $\begin{array}{l}\text { Sauvie Island Moorage } \\
\text { Company }\end{array}$ & $\mathrm{C}$ & $\begin{array}{l}453852 / \\
1224926\end{array}$ & 86.3 & Multnomah Channel & 19.0 & Domestic & .0075 & $*$ & \\
\hline
\end{tabular}


Table 46. Point-source locations and National Pollutant Discharge Elimination System permit levels of effluent discharge, lower Columbia River Basin, Oregon and Washington, 1994-Continued

[Effluent discharge levels are reported in million gallons per day; STP, sewage-treatment plant; --, not applicable; *, value is based on average dry-weather design flow to facility; WTP, water-treatment plant;

NA, data is not known or not shown on permit; \#1 indicates outfall number; Stormwater, discharge is stormwater, therefore no discharge limits are in effect; avg, average; max, maximum; Industrial, permittee

is classified as industrial and, therefore, has limits only on concentrations, not discharge; Misc, miscellaneous; UST, underground storage tank; PAH, polyaromatic hydrocarbons; Ref., references are: A $=$ Tetra Tech, Inc., 1992

B = Tim Hilliard, Washington Department of Ecology, unpub. data, 1995,

C $=$ Debra Nesbit, Oregon Department of Environmental Quality, written commun., 1995 ,

$\mathrm{D}=$ Drew Gilken, Oregon Steel Mills, Inc., oral commun., 1995]

\begin{tabular}{|c|c|c|c|c|c|c|c|c|c|}
\hline Point-source name & Ref. & $\begin{array}{l}\text { Latitude/ } \\
\text { longitude }\end{array}$ & $\begin{array}{l}\text { Columbia } \\
\text { river mile }\end{array}$ & Receiving water body & $\begin{array}{l}\text { Tributary } \\
\text { river mile }\end{array}$ & $\begin{array}{c}\text { Source } \\
\text { classification }\end{array}$ & $\begin{array}{c}\text { Effluent } \\
\text { discharge level }\end{array}$ & Time unit & Constituents of concern \\
\hline Scappoose STP & $\mathrm{C}$ & $\begin{array}{l}454449 / \\
1225019\end{array}$ & 86.3 & Multnomah Channel & 10.5 & Domestic & 2.015 & $*$ & \\
\hline Stella STP & B & $\begin{array}{l}461126 / \\
1230720\end{array}$ & 56.4 & Columbia River & -- & Domestic & 0.0035 & $\begin{array}{l}\text { daily } \\
\text { maximum }\end{array}$ & \\
\hline Three D Corporation & $\mathrm{C}$ & $\begin{array}{l}460840 / \\
1234839\end{array}$ & 12 & Youngs River & 2.0 & Domestic & $.62^{\mathrm{a}}$ & * & \\
\hline Troutdale STP & $\mathrm{C}$ & $\begin{array}{l}453244 / \\
1222308\end{array}$ & 120.5 & Sandy River & 2.3 & Domestic & 1.6 & $*$ & \\
\hline $\begin{array}{l}\text { U.S. Army Corps of } \\
\text { Engineers }\end{array}$ & A & $\begin{array}{l}453840 / \\
1215631\end{array}$ & 146.1 & Columbia River & -- & Domestic & .2 & $*$ & \\
\hline Vancouver-East STP & B & $\begin{array}{l}453645 / \\
1223700\end{array}$ & 110 & Columbia River & -- & Domestic & 4 & monthly average & \\
\hline Vancouver-West STP & B & $\begin{array}{l}453810 / \\
1224145\end{array}$ & 105 & Columbia River & -- & Domestic & 15.2 & monthly average & \\
\hline Warrenton STP & A & $\begin{array}{l}461000 / \\
1235517\end{array}$ & 7 & Columbia River & -- & Domestic & .45 & $*$ & \\
\hline Washougal STP & B & $\begin{array}{l}453411 / \\
1222045\end{array}$ & NA & Columbia River & -- & Domestic & 1.13 & monthly average & \\
\hline $\begin{array}{l}\text { Woodbrook STP } \\
\text { (Cowlitz County) }\end{array}$ & B & $\begin{array}{l}461249 / \\
1225050\end{array}$ & 68 & Ostrander Creek & NA & Domestic & .09 & monthly average & \\
\hline Woodland STP & B & $\begin{array}{l}455904 / \\
1224410\end{array}$ & 87 & Lewis River & NA & Domestic & .48 & monthly average & \\
\hline $\begin{array}{l}\text { Ash Grove Cement } \\
\text { Company }\end{array}$ & $\mathrm{C}$ & $\begin{array}{l}453707 / \\
1224656\end{array}$ & 101.5 & Willamette River & 3.0 & Chemical & Stormwater & -- & \\
\hline $\begin{array}{l}\text { Burlington } \\
\text { Environmental }\end{array}$ & B & $\begin{array}{l}453423 / \\
1222008\end{array}$ & 123.3 & Gibbons Creek & NA & Chemical & $\begin{array}{l}.003285 \\
.010103\end{array}$ & $\begin{array}{l}\text { daily average } \\
\text { daily maximum }\end{array}$ & \\
\hline $\begin{array}{l}\text { Chevron Chemical } \\
\text { Company }\end{array}$ & A & $\begin{array}{l}455510 / \\
1224852\end{array}$ & 82 & Columbia River & -- & Chemical & 25 & $\begin{array}{l}\text { daily } \\
\text { maximum }\end{array}$ & \\
\hline
\end{tabular}


Table 46. Point-source locations and National Pollutant Discharge Elimination System permit levels of effluent discharge, lower Columbia River Basin, Oregon and Washington, 1994-Continued

[Effluent discharge levels are reported in million gallons per day; STP, sewage-treatment plant; --, not applicable; *, value is based on average dry-weather design flow to facility; WTP, water-treatment plant;

NA, data is not known or not shown on permit; \#1 indicates outfall number; Stormwater, discharge is stormwater, therefore no discharge limits are in effect; avg, average; max, maximum; Industrial, permittee

is classified as industrial and, therefore, has limits only on concentrations, not discharge; Misc, miscellaneous; UST, underground storage tank; PAH, polyaromatic hydrocarbons; Ref., references are: A $=$ Tetra Tech, Inc., 1992,

B = Tim Hilliard, Washington Department of Ecology, unpub. data, 1995,

C $=$ Debra Nesbit, Oregon Department of Environmental Quality, written commun., 1995 ,

$\mathrm{D}=$ Drew Gilken, Oregon Steel Mills, Inc., oral commun., 1995]

\begin{tabular}{|c|c|c|c|c|c|c|c|c|c|}
\hline Point-source name & Ref. & $\begin{array}{l}\text { Latitude/ } \\
\text { longitude }\end{array}$ & $\begin{array}{c}\text { Columbia } \\
\text { river mile }\end{array}$ & Receiving water body & $\begin{array}{l}\text { Tributary } \\
\text { river mile }\end{array}$ & $\begin{array}{c}\text { Source } \\
\text { classification }\end{array}$ & $\begin{array}{c}\text { Effluent } \\
\text { discharge level }\end{array}$ & Time unit & Constituents of concern \\
\hline Cytec Industries & $\mathrm{B}$ & $\begin{array}{l}460758 / \\
1225530\end{array}$ & NA & $\begin{array}{l}\text { Diking } \\
\text { Improvement } \\
\text { District \#1 }\end{array}$ & NA & Chemical & $\begin{array}{c}\# 1: 0.082 \\
.12 \\
\# 2: 0.53 \\
1.7\end{array}$ & $\begin{array}{l}\text { daily average } \\
\text { daily maximum } \\
\text { daily average } \\
\text { daily maximum }\end{array}$ & organics \\
\hline $\begin{array}{l}\text { E.F. Houghton and } \\
\text { Company }\end{array}$ & B & $\begin{array}{l}460704 / \\
1225615\end{array}$ & NA & Drain ditch \#3 & NA & Chemical & 0.01 & $\begin{array}{l}\text { daily } \\
\text { maximum }\end{array}$ & \\
\hline $\begin{array}{l}\text { Elf Atochem North } \\
\text { America, Inc. }\end{array}$ & $\mathrm{C}$ & $\begin{array}{l}453415 / \\
1224430\end{array}$ & 101.5 & Willamette River & 7.4 & Chemical & 37.0 & $\begin{array}{l}\text { daily } \\
\text { maximum }\end{array}$ & $\mathrm{Cr}, \mathrm{Cu}, \mathrm{Ni}, \mathrm{Pb}, \mathrm{Zn}$ \\
\hline GATX Terminals & B & $\begin{array}{l}453809 / \\
1224238\end{array}$ & 104 & Columbia River & -- & Chemical & NA & -- & total toxic organics \\
\hline $\begin{array}{l}\text { Hoechst-Celanes } \\
\text { Corporation } \\
\text { (Virginia Chemicals, } \\
\text { Inc.) }\end{array}$ & $\mathrm{B}$ & $\begin{array}{l}455943 / \\
1225029\end{array}$ & 76 & Columbia River & -- & Chemical & $\begin{array}{l}1 \\
1.5\end{array}$ & $\begin{array}{l}\text { daily average } \\
\text { daily maximum }\end{array}$ & $\mathrm{Zn}$ \\
\hline Kalama Chemical & $\mathrm{B}$ & $\begin{array}{l}460118 / \\
1225135\end{array}$ & 74 & Columbia River & -- & Chemical & .225 & $\begin{array}{l}\text { daily } \\
\text { maximum }\end{array}$ & $\begin{array}{l}\text { As, } \mathrm{Co}, \mathrm{Cr}, \mathrm{Cu}, \mathrm{Ni}, \mathrm{Zn} \text {, } \\
\text { organics }\end{array}$ \\
\hline SEH America, Inc. & $\mathrm{B}$ & $\begin{array}{l}453906 / \\
1223324\end{array}$ & 87.6 & $\begin{array}{l}\text { Burnt Bridge Creek/ } \\
\text { Vancouver STP }\end{array}$ & NA & Chemical & $\begin{array}{l}1.2 \\
3.9\end{array}$ & $\begin{array}{l}\text { daily average } \\
\text { daily maximum }\end{array}$ & $\begin{array}{l}\text { total metals, total toxic } \\
\text { organics, conductivity }\end{array}$ \\
\hline $\begin{array}{l}\text { Union Carbide } \\
\text { (Washougal) }\end{array}$ & $\mathrm{B}$ & $\begin{array}{l}453419 / \\
1221953\end{array}$ & 123.3 & $\begin{array}{l}\text { Gibbons Creek/ } \\
\text { Washougal WTP }\end{array}$ & NA & Chemical & $\begin{array}{l}.06 \\
.085\end{array}$ & $\begin{array}{l}\text { daily averag } \\
\text { daily maximum }\end{array}$ & As, $F$, total organics \\
\hline $\begin{array}{l}\text { Wacker Siltronic } \\
\text { Corporation }\end{array}$ & $\mathrm{C}$ & $\begin{array}{l}453436 / \\
1224510\end{array}$ & 101.5 & Willamette River & 6.6 & Chemical & $.732^{\mathrm{b}}$ & $\begin{array}{l}\text { daily } \\
\text { maximum }\end{array}$ & $\begin{array}{l}\mathrm{Al}, \mathrm{As}, \mathrm{Cr}^{+6}, \mathrm{~F}, \mathrm{P}, \mathrm{Zn}, \\
\text { total toxic organics }\end{array}$ \\
\hline $\begin{array}{l}\text { Allweather Wood } \\
\text { Treaters }\end{array}$ & $\mathrm{B}$ & $\begin{array}{l}453416 / \\
1222007\end{array}$ & 123.3 & Gibbons Creek & NA & Wood & NA & -- & $\mathrm{As}, \mathrm{Cr}, \mathrm{Cu}$ \\
\hline $\begin{array}{l}\text { Astoria Plywood } \\
\text { Company }\end{array}$ & A & $\begin{array}{l}461123 / \\
1234846\end{array}$ & 15 & Columbia River & -- & Wood & $\begin{array}{l}\text { as low as } \\
\text { practicable }\end{array}$ & -- & $\begin{array}{l}\mathrm{Cd}, \mathrm{Cr}, \mathrm{Cu}, \mathrm{Zn} \text {, phenols, } \\
\text { creosote compounds }\end{array}$ \\
\hline $\begin{array}{l}\text { Boise Cascade } \\
\text { St. Helens Veneer Mill }\end{array}$ & A & $\begin{array}{l}455051 / \\
1224807\end{array}$ & 86 & Columbia River & -- & Wood & .5 & $\begin{array}{l}\text { daily } \\
\text { maximum }\end{array}$ & $\begin{array}{l}\mathrm{Cd}, \mathrm{Cr}, \mathrm{Cu}, \mathrm{Zn} \text {, phenols, } \\
\text { creosote compounds }\end{array}$ \\
\hline $\begin{array}{l}\text { Columbia Vista } \\
\text { Corporation }\end{array}$ & B & $\begin{array}{l}453510 / \\
1222805\end{array}$ & 115.6 & Columbia River & -- & Wood & $\begin{array}{l}\text { permit } \\
\text { canceled }\end{array}$ & -- & $\begin{array}{l}\text { pentachlorophenol, } \\
\text { total metals }\end{array}$ \\
\hline
\end{tabular}


Table 46. Point-source locations and National Pollutant Discharge Elimination System permit levels of effluent discharge, lower Columbia River Basin, Oregon and Washington, 1994-Continued

[Effluent discharge levels are reported in million gallons per day; STP, sewage-treatment plant; --, not applicable; *, value is based on average dry-weather design flow to facility; WTP, water-treatment plant;

NA, data is not known or not shown on permit; \#1 indicates outfall number; Stormwater, discharge is stormwater, therefore no discharge limits are in effect; avg, average; max, maximum; Industrial, permittee

is classified as industrial and, therefore, has limits only on concentrations, not discharge; Misc, miscellaneous; UST, underground storage tank; PAH, polyaromatic hydrocarbons; Ref., references are: A $=$ Tetra Tech, Inc., 1992

B = Tim Hilliard, Washington Department of Ecology, unpub. data, 1995,

C $=$ Debra Nesbit, Oregon Department of Environmental Quality, written commun., 1995,

$\mathrm{D}=$ Drew Gilken, Oregon Steel Mills, Inc., oral commun., 1995]

\begin{tabular}{|c|c|c|c|c|c|c|c|c|c|}
\hline Point-source name & Ref. & $\begin{array}{l}\text { Latitude/ } \\
\text { longitude }\end{array}$ & $\begin{array}{c}\text { Columbia } \\
\text { river mile }\end{array}$ & Receiving water body & $\begin{array}{l}\text { Tributary } \\
\text { river mile }\end{array}$ & $\begin{array}{c}\text { Source } \\
\text { classification }\end{array}$ & $\begin{array}{c}\text { Effluent } \\
\text { discharge level }\end{array}$ & Time unit & Constituents of concern \\
\hline Exterior Wood, Inc. & B & $\begin{array}{l}453500 / \\
1222100\end{array}$ & 123.3 & Gibbons Creek & NA & Wood & NA & -- & $\mathrm{As}, \mathrm{Cr}, \mathrm{Cu}$ \\
\hline $\begin{array}{l}\text { Fort Vancouver } \\
\text { Plywood Company }\end{array}$ & B & $\begin{array}{l}453744 / \\
1224124\end{array}$ & 105.2 & Columbia River & -- & Wood & NA & -- & \\
\hline $\begin{array}{l}\text { International Paper } \\
\text { Company }\end{array}$ & B & $\begin{array}{l}460615 / \\
1225700\end{array}$ & 66.5 & Columbia River & -- & Wood & 0.25 & monthly average & \\
\hline $\begin{array}{l}\text { James River Sundial } \\
\text { Chip Reloading Facil- } \\
\text { ity }\end{array}$ & A & $\begin{array}{l}453356 / \\
1222547\end{array}$ & 119 & Columbia River & -- & Wood & Industrial & -- & $\begin{array}{l}\mathrm{Cd}, \mathrm{Cr}, \mathrm{Cu}, \mathrm{Zn} \text {, phenols, } \\
\text { creosote compounds }\end{array}$ \\
\hline $\begin{array}{l}\text { Linnton Plywood } \\
\text { Association }\end{array}$ & $\mathrm{C}$ & $\begin{array}{l}453557 / \\
1224646\end{array}$ & 101.5 & Willamette River & 4.8 & Wood & NA & -- & \\
\hline Pacific Wood Treating & B & $\begin{array}{l}454915 / \\
1224504\end{array}$ & 87.5 & Lake River & NA & Wood & NA & -- & $\begin{array}{l}\mathrm{As}, \mathrm{Cr}, \mathrm{Cu} \text {, aromatics, } \\
\text { pentachlorophenol }\end{array}$ \\
\hline $\begin{array}{l}\text { Weyerhauser Company } \\
\text { (Wood product) }\end{array}$ & B & $\begin{array}{l}460755 / \\
1225837\end{array}$ & NA & $\begin{array}{l}\text { Diking drainage } \\
\text { ditch \#3 }\end{array}$ & NA & Wood & Industrial & -- & $\begin{array}{l}\mathrm{Cd}, \mathrm{Cr}, \mathrm{Cu}, \mathrm{Zn} \text {, phenols, } \\
\text { creosote compounds }\end{array}$ \\
\hline Ameron Pipe Products & $\mathrm{C}$ & $\begin{array}{l}453447 / \\
1223922\end{array}$ & 101.5 & Willamette River & 6.5 & Misc & $\begin{array}{l}\text { \#1: no discharge } \\
\text { \#2: } 0.00005 \\
\text { \#3: } 0.5 \\
\text { \#4: no discharge }\end{array}$ & $\begin{array}{l}\text {-- } \\
\text { daily maximum } \\
\text { daily maximum } \\
--\end{array}$ & \\
\hline $\begin{array}{l}\text { Fiberweb North Amer- } \\
\text { ica }\end{array}$ & B & $\begin{array}{l}453351 / \\
1221919\end{array}$ & 123.3 & Gibbons Creek & NA & Misc & .0735 & $\begin{array}{l}\text { daily } \\
\text { maximum }\end{array}$ & \\
\hline Great Western Malting & B & $\begin{array}{l}453752 / \\
1224139\end{array}$ & 105.1 & Columbia River & -- & Misc & 9.9 & $\begin{array}{l}\text { daily } \\
\text { maximum }\end{array}$ & temperature \\
\hline $\begin{array}{l}\text { Holnam, Inc. } \\
\text { (Ideal Basic Industries) }\end{array}$ & B & $\begin{array}{l}453737 / \\
1224111\end{array}$ & 105.5 & Columbia River & -- & Misc & .004999 & $\begin{array}{l}\text { daily } \\
\text { maximum }\end{array}$ & \\
\hline Lone Star Northwest, & $\mathrm{C}$ & $453012 /$ & 101.5 & Willamette River & 13.8 & Misc & NA & -- & \\
\hline
\end{tabular}


Table 46. Point-source locations and National Pollutant Discharge Elimination System permit levels of effluent discharge, lower Columbia River Basin, Oregon and Washington, 1994-Continued

[Effluent discharge levels are reported in million gallons per day; STP, sewage-treatment plant; --, not applicable; *, value is based on average dry-weather design flow to facility; WTP, water-treatment plant; NA, data is not known or not shown on permit; \#1 indicates outfall number; Stormwater, discharge is stormwater, therefore no discharge limits are in effect; avg, average; max, maximum; Industrial, permittee is classified as industrial and, therefore, has limits only on concentrations, not discharge; Misc, miscellaneous; UST, underground storage tank; PAH, polyaromatic hydrocarbons; Ref., references are:

A $=$ Tetra Tech, Inc., 1992,

B = Tim Hilliard, Washington Department of Ecology, unpub. data, 1995,

C = Debra Nesbit, Oregon Department of Environmental Quality, written commun., 1995,

$\mathrm{D}=$ Drew Gilken, Oregon Steel Mills, Inc., oral commun., 1995]

\begin{tabular}{|c|c|c|c|c|c|c|c|c|c|}
\hline Point-source name & Ref. & $\begin{array}{l}\text { Latitude/ } \\
\text { longitude }\end{array}$ & $\begin{array}{l}\text { Columbia } \\
\text { river mile }\end{array}$ & Receiving water body & $\begin{array}{l}\text { Tributary } \\
\text { river mile }\end{array}$ & $\begin{array}{c}\text { Source } \\
\text { classification }\end{array}$ & $\begin{array}{c}\text { Effluent } \\
\text { discharge level }\end{array}$ & Time unit & Constituents of concern \\
\hline $\begin{array}{l}\text { Northwest Packing } \\
\text { Company }\end{array}$ & $\mathrm{B}$ & $\begin{array}{l}453756 / \\
1224123\end{array}$ & 105.1 & Columbia River & -- & Misc & $\begin{array}{c}\# 1: 0.072 \\
.015 \\
\# 4: 0.0115 \\
.072\end{array}$ & $\begin{array}{l}\text { daily average } \\
\text { daily maximum } \\
\text { daily average } \\
\text { daily maximum }\end{array}$ & temperature \\
\hline $\begin{array}{l}\text { Oregon Museum of } \\
\text { Science and Industry }\end{array}$ & $\mathrm{C}$ & $\begin{array}{l}453036 / \\
1224000\end{array}$ & 101.5 & Willamette River & 13.5 & Misc & .575 & $\begin{array}{l}\text { daily } \\
\text { maximum }\end{array}$ & \\
\hline $\begin{array}{l}\text { Oregon Steel Mills, } \\
\text { Inc. }\end{array}$ & $\mathrm{D}$ & $\begin{array}{l}453745 / \\
1224705\end{array}$ & 101.5 & Willamette River & 1.7 & Misc & no discharge ${ }^{\mathrm{d}}$ & -- & \\
\hline $\begin{array}{l}\text { Pendelton Woolen } \\
\text { Mills }\end{array}$ & $\mathrm{B}$ & $\begin{array}{l}453427 / \\
1222104\end{array}$ & 122.8 & Columbia River & NA & Misc & $\begin{array}{l}1 \\
1.25\end{array}$ & $\begin{array}{l}\text { daily average } \\
\text { daily maximum }\end{array}$ & $\begin{array}{l}\text { total } \mathrm{Cr} \text {, phenol, } \\
\text { sulfide, dieldrin }\end{array}$ \\
\hline $\begin{array}{l}\text { Port of Portland } \\
\text { Terminal } 5 \text { (Bulk stor- } \\
\text { age) }\end{array}$ & $\mathrm{C}$ & $\begin{array}{l}453742 / \\
1224707\end{array}$ & 101.5 & Willamette River & 1.5 & Misc & NA & -- & \\
\hline $\begin{array}{l}\text { Astoria Seafood } \\
\text { Company }\end{array}$ & A & $\begin{array}{l}461111 / \\
1235134\end{array}$ & 12 & Columbia River & -- & $\begin{array}{l}\text { Seafood } \\
\text { processing }\end{array}$ & NA & -- & nutrients \\
\hline Bioproducts, Inc. & A & $\begin{array}{l}461010 / \\
1235451\end{array}$ & 10.8 & Columbia River & -- & $\begin{array}{l}\text { Seafood } \\
\text { processing }\end{array}$ & .52 & monthly average & nutrients \\
\hline $\begin{array}{l}\text { Chinook Packing } \\
\text { Company }\end{array}$ & $\mathrm{B}$ & $\begin{array}{l}461618 / \\
1235648\end{array}$ & 6 & $\begin{array}{l}\text { Columbia River/ } \\
\text { Baker Bay }\end{array}$ & -- & $\begin{array}{l}\text { Seafood } \\
\text { processing }\end{array}$ & .7 & $\begin{array}{l}\text { daily } \\
\text { maximum }\end{array}$ & nutrients \\
\hline $\begin{array}{l}\text { Jessie's Ilwaco Fish } \\
\text { Company, Inc. }\end{array}$ & $\mathrm{B}$ & $\begin{array}{l}461827 / \\
1240214\end{array}$ & 3 & $\begin{array}{l}\text { Columbia River/ } \\
\text { Baker Bay }\end{array}$ & -- & $\begin{array}{l}\text { Seafood } \\
\text { processing }\end{array}$ & .25 & $\begin{array}{l}\text { daily } \\
\text { maximum }\end{array}$ & nutrients \\
\hline Ocean Foods of Astoria & A & $\begin{array}{l}461051 / \\
1235134\end{array}$ & 12 & Columbia River & -- & $\begin{array}{l}\text { Seafood } \\
\text { processing }\end{array}$ & NA & -- & nutrients \\
\hline $\begin{array}{l}\text { Pacific Coast Seafood } \\
\text { Company }\end{array}$ & A & $\begin{array}{l}461000 / \\
1235426\end{array}$ & 11 & Columbia River & -- & $\begin{array}{l}\text { Seafood } \\
\text { processing }\end{array}$ & NA & -- & nutrients \\
\hline $\begin{array}{l}\text { Point Adams Packing } \\
\text { Company }\end{array}$ & A & $\begin{array}{l}461152 / \\
1235622\end{array}$ & 9 & Columbia River & -- & $\begin{array}{l}\text { Seafood } \\
\text { processing }\end{array}$ & NA & -- & nutrients \\
\hline $\begin{array}{l}\text { Warrenton Deep Sea, } \\
\text { Inc. }\end{array}$ & A & $\begin{array}{l}461024 / \\
1235443\end{array}$ & 7 & Columbia River & -- & $\begin{array}{l}\text { Seafood } \\
\text { processing }\end{array}$ & NA & -- & nutrients \\
\hline
\end{tabular}


Table 46. Point-source locations and National Pollutant Discharge Elimination System permit levels of effluent discharge, lower Columbia River Basin, Oregon and

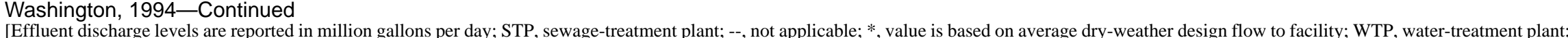

NA, data is not known or not shown on permit; \#1 indicates outfall number; Stormwater, discharge is stormwater, therefore no discharge limits are in effect; avg, average; max, maximum; Industrial, permittee is classified as industrial and, therefore, has limits only on concentrations, not discharge; Misc, miscellaneous; UST, underground storage tank; PAH, polyaromatic hydrocarbons; Ref., references are: A $=$ Tetra Tech, Inc., 1992

B = Tim Hilliard, Washington Department of Ecology, unpub. data, 1995,

C = Debra Nesbit, Oregon Department of Environmental Quality, written commun., 1995 ,

$\mathrm{D}=$ Drew Gilken, Oregon Steel Mills, Inc., oral commun., 1995]

\begin{tabular}{|c|c|c|c|c|c|c|c|c|c|}
\hline Point-source name & Ref. & $\begin{array}{l}\text { Latitude/ } \\
\text { longitude }\end{array}$ & $\begin{array}{l}\text { Columbia } \\
\text { river mile }\end{array}$ & Receiving water body & $\begin{array}{l}\text { Tributary } \\
\text { river mile }\end{array}$ & $\begin{array}{c}\text { Source } \\
\text { classification }\end{array}$ & $\begin{array}{c}\text { Effluent } \\
\text { discharge level }\end{array}$ & Time unit & Constituents of concern \\
\hline $\begin{array}{l}\text { Boise Cascade-- } \\
\text { Vancouver }\end{array}$ & $\mathrm{B}$ & $\begin{array}{l}453736 / \\
1224045\end{array}$ & 106 & Columbia River & -- & $\begin{array}{l}\text { Paper and } \\
\text { pulp }\end{array}$ & Industrial & -- & $\begin{array}{l}\mathrm{Cu}, \mathrm{Ni}, \mathrm{Pb}, \text { biocides, } \\
\text { chlorinated organics }\end{array}$ \\
\hline James River--Camas & $\mathrm{B}$ & $\begin{array}{l}453506 / \\
1222416\end{array}$ & 120.1 & Columbia River & -- & $\begin{array}{l}\text { Paper and } \\
\text { pulp }\end{array}$ & Industrial & -- & $\begin{array}{l}\mathrm{Cu}, \mathrm{Ni}, \mathrm{Pb} \text {, biocides, } \\
\text { chlorinated organics }\end{array}$ \\
\hline $\begin{array}{l}\text { James River II-- } \\
\text { Wauna Mill }\end{array}$ & A & $\begin{array}{l}460913 / \\
1232351\end{array}$ & 42 & Columbia River & -- & $\begin{array}{l}\text { Paper and } \\
\text { pulp }\end{array}$ & Industrial & -- & $\begin{array}{l}\mathrm{Cu}, \mathrm{Ni}, \mathrm{Pb} \text {, biocides, } \\
\text { chlorinated organics }\end{array}$ \\
\hline $\begin{array}{l}\text { Longview Fibre-- } \\
\text { Longview }\end{array}$ & B & $\begin{array}{l}460545 / \\
1225500\end{array}$ & 67.5 & Columbia River & -- & $\begin{array}{l}\text { Paper and } \\
\text { pulp }\end{array}$ & Industrial & -- & $\begin{array}{l}\mathrm{Cu}, \mathrm{Ni}, \mathrm{Pb} \text {, biocides, } \\
\text { chlorinated organics }\end{array}$ \\
\hline $\begin{array}{l}\text { Weyerhauser-- } \\
\text { Longview }\end{array}$ & B & $\begin{array}{l}460750 / \\
1225927\end{array}$ & 63.5 & Columbia River & -- & $\begin{array}{l}\text { Paper and } \\
\text { pulp }\end{array}$ & Industrial & -- & $\begin{array}{l}\mathrm{Cu}, \mathrm{Ni}, \mathrm{Pb} \text {, biocides, } \\
\text { chlorinated organics }\end{array}$ \\
\hline ALCOA--Vancouver & $\mathrm{B}$ & $\begin{array}{l}453858 / \\
1224441\end{array}$ & 103 & Columbia River & -- & Aluminum & Industrial & -- & $\begin{array}{l}\text { phenolics, cyanide, } \\
\mathrm{Cr}^{+6}, \mathrm{Al}, \mathrm{Ni}, \mathrm{Sb}, \mathrm{Zn}, \\
\text { total } \mathrm{Cr} \text {, benzo(a)pyrene }\end{array}$ \\
\hline Reynolds Metal ${ }^{\mathrm{e}}$ & B & $\begin{array}{l}461049 / \\
1231045\end{array}$ & NA & Columbia River & -- & Aluminum & NA & -- & $\mathrm{Fe}$ \\
\hline $\begin{array}{l}\text { Reynolds Metal-- } \\
\text { Longview }\end{array}$ & B & $\begin{array}{l}460805 / \\
1230010\end{array}$ & 63 & Columbia River & -- & Aluminum & Industrial & -- & $\begin{array}{l}\mathrm{Cd}, \mathrm{Cu}, \mathrm{F}, \mathrm{Ni}, \mathrm{Pb}, \mathrm{Sb}, \\
\mathrm{Zn} \text {, cyanide }\end{array}$ \\
\hline $\begin{array}{l}\text { Reynolds Metal-- } \\
\text { Troutdale }\end{array}$ & A & $\begin{array}{l}453324 / \\
1222356\end{array}$ & 120 & Columbia River & -- & Aluminum & Industrial & -- & $\begin{array}{l}\mathrm{Al}, \mathrm{Cr}, \mathrm{F}, \mathrm{Ni}, \mathrm{Sb}, \mathrm{Zn}, \\
\text { benzo(a)pyrene }\end{array}$ \\
\hline Ilwaco Boat Hoist & B & $\begin{array}{l}461822 / \\
1220205\end{array}$ & NA & Columbia River & -- & Boat yard & .0144 & $\begin{array}{l}\text { daily } \\
\text { maximum }\end{array}$ & $\mathrm{As}, \mathrm{Cu}, \mathrm{Pb}, \mathrm{Zn}$ \\
\hline $\begin{array}{l}\text { Port of Ilwaco Boat- } \\
\text { yard and Marina }\end{array}$ & B & $\begin{array}{l}461820 / \\
1240230\end{array}$ & NA & Columbia River & -- & Boat yard & .0144 & $\begin{array}{l}\text { daily } \\
\text { maximum }\end{array}$ & $\mathrm{As}, \mathrm{Cu}, \mathrm{Pb}, \mathrm{Zn}$ \\
\hline $\begin{array}{l}\text { Port of Portland-- } \\
\text { Portland Shipyard }\end{array}$ & $\mathrm{C}$ & $\begin{array}{l}453400 / \\
1224314\end{array}$ & 101.5 & Willamette River & 6.5 & Boat yard & $\begin{array}{l}\# 1: 0.110 \\
\# 2: 0.101 \\
\# 3: 0.288\end{array}$ & $\begin{array}{l}\text { daily max } \\
\text { daily max } \\
\text { daily max }\end{array}$ & \\
\hline $\begin{array}{l}\text { Oregon Department of } \\
\text { Fish and Wildlife }\end{array}$ & A & $\begin{array}{l}460230 / \\
1225304\end{array}$ & 73 & Columbia River & -- & Fish hatchery & NA & -- & $\begin{array}{l}\text { antibiotic } \\
\text { chemicals }\end{array}$ \\
\hline
\end{tabular}


Table 46. Point-source locations and National Pollutant Discharge Elimination System permit levels of effluent discharge, lower Columbia River Basin, Oregon and Washington, 1994-Continued

[Effluent discharge levels are reported in million gallons per day; STP, sewage-treatment plant; --, not applicable; *, value is based on average dry-weather design flow to facility; WTP, water-treatment plant;

NA, data is not known or not shown on permit; \#1 indicates outfall number; Stormwater, discharge is stormwater, therefore no discharge limits are in effect; avg, average; max, maximum; Industrial, permittee is classified as industrial and, therefore, has limits only on concentrations, not discharge; Misc, miscellaneous; UST, underground storage tank; PAH, polyaromatic hydrocarbons; Ref., references are:

A = Tetra Tech, Inc., 1992

B = Tim Hilliard, Washington Department of Ecology, unpub. data, 1995,

C = Debra Nesbit, Oregon Department of Environmental Quality, written commun., 1995,

D = Drew Gilken, Oregon Steel Mills, Inc., oral commun., 1995]

\begin{tabular}{|c|c|c|c|c|c|c|c|c|c|}
\hline Point-source name & Ref. & $\begin{array}{l}\text { Latitude/ } \\
\text { longitude }\end{array}$ & $\begin{array}{l}\text { Columbia } \\
\text { river mile }\end{array}$ & Receiving water body & $\begin{array}{l}\text { Tributary } \\
\text { river mile }\end{array}$ & $\begin{array}{c}\text { Source } \\
\text { classification }\end{array}$ & $\begin{array}{c}\text { Effluent } \\
\text { discharge level }\end{array}$ & Time unit & Constituents of concern \\
\hline $\begin{array}{l}\text { Oregon Department of } \\
\text { Fish and Wildlife } \\
\text { (Wahkeena) }\end{array}$ & $\mathrm{A}$ & $\begin{array}{l}453434 / \\
1220756\end{array}$ & 134 & Columbia River & -- & Fish hatchery & NA & -- & $\begin{array}{l}\text { antibiotic } \\
\text { chemicals }\end{array}$ \\
\hline $\begin{array}{l}\text { Vancouver Trout } \\
\text { Hatchery }\end{array}$ & A & $\begin{array}{l}453459 / \\
1223237\end{array}$ & 113.5 & Columbia River & -- & Fish hatchery & 4.05 & $\begin{array}{l}\text { daily } \\
\text { average }\end{array}$ & $\begin{array}{l}\text { antibiotic } \\
\text { chemicals }\end{array}$ \\
\hline $\begin{array}{l}\text { Canonie Environmen- } \\
\text { tal Service Corp. } \\
\text { (Gould Superfund site) }\end{array}$ & $\mathrm{C}$ & $\begin{array}{l}453432 / \\
1224451\end{array}$ & 101.5 & Willamette River & 7.0 & Remediation & .007 & $\begin{array}{l}\text { daily } \\
\text { maximum }\end{array}$ & $\begin{array}{l}\mathrm{Ag}, \mathrm{Cr}^{+6}, \mathrm{Cu}, \mathrm{Hg}, \mathrm{Ni} \\
\mathrm{Pb}, \mathrm{Zn}\end{array}$ \\
\hline $\begin{array}{l}\text { Union Oil Company of } \\
\text { California--Willbridge } \\
\text { Bulk Terminal }\end{array}$ & $\mathrm{C}$ & $\begin{array}{l}453420 / \\
1224408\end{array}$ & 101.5 & Willamette River & 5.7 & Remediation & $.144^{\mathrm{f}}$ & $\begin{array}{l}\text { daily } \\
\text { maximum }\end{array}$ & $\begin{array}{l}\text { benzene, toluene, ethyl- } \\
\text { benzene, xylenes, total } \\
\text { petroleum hydrocarbons }\end{array}$ \\
\hline $\begin{array}{l}\text { Western Station Corp. } \\
\text { UST \#606 }\end{array}$ & $\mathrm{B}$ & $\begin{array}{l}454205 / \\
1224005\end{array}$ & 68 & Salmon Creek & NA & Remediation & $\begin{array}{l}.003 \\
.003\end{array}$ & $\begin{array}{l}\text { dail y average } \\
\text { daily maximum }\end{array}$ & $\mathrm{Pb}$, benzene \\
\hline $\begin{array}{l}\text { Chevron USA, Inc.-- } \\
\text { Willbridge Distribu- } \\
\text { tion Center }\end{array}$ & $\mathrm{C}$ & $\begin{array}{l}453357 / \\
1224415\end{array}$ & 101.5 & Willamette River & 7.9 & Tank farm & NA & -- & \\
\hline Koppers Industry, Inc. & $\mathrm{C}$ & $\begin{array}{l}453438 / \\
1224532\end{array}$ & 101.5 & Willamette River & 6.5 & Tank farm & $.006^{\mathrm{g}}$ & $\begin{array}{l}\text { daily } \\
\text { maximum }\end{array}$ & $\begin{array}{l}\text { toluene, phenols, } \\
\text { metals, anthracene, } \\
\text { PAHs, fluoranthene }\end{array}$ \\
\hline $\begin{array}{l}\text { Beaver Generating } \\
\text { Plant }\end{array}$ & A & $\begin{array}{l}461026 / \\
1231031\end{array}$ & 54 & Columbia River & -- & $\begin{array}{l}\text { Power } \\
\text { generating }\end{array}$ & 1.44 & $\begin{array}{l}\text { daily } \\
\text { maximum }\end{array}$ & $\mathrm{Al}, \mathrm{B}, \mathrm{Cu}, \mathrm{Fe}$, \\
\hline $\begin{array}{l}\text { Trojan Nuclear Power } \\
\text { Plant }\end{array}$ & A & $\begin{array}{l}460226 / \\
1225256\end{array}$ & 72.5 & Columbia River & -- & $\begin{array}{l}\text { Power } \\
\text { generating }\end{array}$ & 64.3 & $\begin{array}{l}\text { daily } \\
\text { maximum }\end{array}$ & $\mathrm{Al}, \mathrm{B}, \mathrm{Cu}, \mathrm{Fe}$ \\
\hline
\end{tabular}

${ }^{a}$ Value is from renewal application dated 07/07/1992.

${ }^{b}$ Value is from renewal application dated 11/12/1991.

${ }^{\mathrm{c}}$ No discharge unless discharge is greater that the recycler's capacity of $0.07 \mathrm{mgd}$.

${ }^{\mathrm{d}}$ No discharge unless discharge is greater than the recycler's capacity. Permit states the limit is $5.76 \mathrm{mgd}$

${ }^{\mathrm{e}} \mathrm{Bicc}$ Cable Corporation doing-business-as Cablec Utility Cable Company.

${ }^{\mathrm{f}}$ Permittee has special permit for discharge of treated groundwater from petroleum hydrocarbon remediation system.

${ }^{\mathrm{g}}$ Value is from permit expiring 07/31/1991. 
Table 47. Summary of trace-element concentrations that exceed screening values derived from water-quality guidelines, lower Columbia River Basin, Oregon and Washington, 1994

[Only detectable concentrations were evaluated against water-quality guidelines; percentages were calculated using all measurements (censored and detected) for all sites sampled; $\mu \mathrm{g} / \mathrm{L}$, micrograms per liter; see table 7 for full site names; --, criteria do not exist to compare values to]

\begin{tabular}{|c|c|c|c|c|c|c|c|}
\hline \multirow{4}{*}{ Site name } & \multirow{4}{*}{$\begin{array}{c}\text { Total } \\
\text { number } \\
\text { of } \\
\text { samples }\end{array}$} & \multicolumn{6}{|c|}{ Number of samples that exceed screening values } \\
\hline & & \multicolumn{4}{|c|}{ Ambient water-quality criteria } & \multicolumn{2}{|c|}{ Drinking-water guidelines } \\
\hline & & \multicolumn{2}{|c|}{ Aquatic life } & \multicolumn{2}{|c|}{ Human health } & \multirow[b]{2}{*}{ Regulation } & \multirow[b]{2}{*}{$\begin{array}{l}\text { Human- } \\
\text { health } \\
\text { advisory }\end{array}$} \\
\hline & & Acute & Chronic & $\begin{array}{c}\text { Aquatic } \\
\text { organisms } \\
\text { and water }\end{array}$ & $\begin{array}{c}\text { Aquatic } \\
\text { organisms } \\
\text { only }\end{array}$ & & \\
\hline \multicolumn{8}{|l|}{ Arsenic: } \\
\hline \multicolumn{8}{|l|}{ Ambient water-quality criteria ${ }^{\mathrm{a}}$ : } \\
\hline \multicolumn{8}{|l|}{ Aquatic life: } \\
\hline \multicolumn{8}{|l|}{ Acute: 1 -hour average $360 \mu \mathrm{g} / \mathrm{L}$ once in three years } \\
\hline \multicolumn{8}{|l|}{ Chronic: 4-day average $190 \mu \mathrm{g} / \mathrm{L}$ once in three years } \\
\hline \multicolumn{8}{|l|}{ Human health: } \\
\hline \multicolumn{8}{|l|}{ Consumption of aquatic organisms and water: $0.18 \mu \mathrm{g} / \mathrm{L}$} \\
\hline \multicolumn{8}{|l|}{ Consumption of aquatic organisms only: $1.4 \mu \mathrm{g} / \mathrm{L}$} \\
\hline \multicolumn{8}{|c|}{$\begin{array}{l}\left.\text { Note: Human-health guidelines are based on a slope factor }\left(\mathrm{q}_{1}{ }^{*}\right) \text { of } 1.75 \text { (milligrams per kilogram per day) }\right)^{-1} \text {, a bioconcentration factor of } 44 \text { liters per kilogram, a life- } \\
\text { time risk of cancer equivalent to } 1 \text { in } 100,000 \text {, a consumption rate of fish of } 6.5 \text { grams per day (about one six-ounce fillet per month--the national average), a con- } \\
\text { sumption rate of water of } 2 \text { liters per day, a body weight of } 70 \text { kilograms ( } 154 \text { pounds), and a life expectancy of } 70 \text { years. }\end{array}$} \\
\hline \multicolumn{8}{|c|}{ Drinking-water guidelines ${ }^{b}$ : } \\
\hline \multicolumn{8}{|l|}{ Regulation: $50.0 \mu \mathrm{g} / \mathrm{L}$ (Maximum Contaminant Level) } \\
\hline \multicolumn{8}{|c|}{ Human-health advisory: $0.2 \mu \mathrm{g} / \mathrm{L}$ Risk-specific dose } \\
\hline \multicolumn{8}{|c|}{$\begin{array}{l}\left.\text { Note: Human-health advisory is based on a slope factor }\left(\mathrm{q}_{1}{ }^{*}\right) \text { of } 1.75 \text { (milligrams per kilogram per day) }\right)^{-1} \text {, a lifetime risk of cancer equivalent to } 1 \text { in } 100,000 \text {, a con- } \\
\text { sumption rate of water of } 2 \text { liters per day, a body weight of } 70 \text { kilograms (154 pounds), and a life expectancy of } 70 \text { years. }\end{array}$} \\
\hline Columbia River at Warrendale & 4 & 0 & 0 & 4 & 0 & 0 & 4 \\
\hline Columbia River at Hayden Island & 4 & 0 & 0 & 4 & 0 & 0 & 4 \\
\hline Multnomah Channel near mouth & 4 & 0 & 0 & 1 & 0 & 0 & 1 \\
\hline Columbia River near Columbia City & 4 & 0 & 0 & 4 & 0 & 0 & 4 \\
\hline Columbia River at Beaver Army Terminal & 4 & 0 & 0 & 3 & 0 & 0 & 3 \\
\hline Percentage of samples that exceed screening values & & 0 & 0 & 38 & 0 & 0 & 38 \\
\hline \\
\hline \multirow{2}{*}{\multicolumn{8}{|c|}{$\begin{array}{l}\text { Ambient water-quality criteria }{ }^{1} \text { : } \\
\text { Aquatic life: }\end{array}$}} \\
\hline \multirow{2}{*}{\multicolumn{8}{|c|}{$\begin{array}{l}\text { Aquatic life: } \\
\text { Chronic: } 1,000 \mu \mathrm{g} / \mathrm{L}\end{array}$}} \\
\hline & & & & & & & \\
\hline \multicolumn{8}{|l|}{ Human health: } \\
\hline \multicolumn{8}{|l|}{ Consumption of aquatic organisms and water: $300 \mu \mathrm{g} / \mathrm{L}$} \\
\hline Willamette River & 25 & -- & 0 & 1 & -- & -- & -- \\
\hline Percentage of samples that exceed screening values & & -- & 0 & 1 & -- & -- & -- \\
\hline
\end{tabular}


Table 47. Summary of trace-element concentrations that exceed screening values derived from water-quality guidelines, lower Columbia River Basin, Oregon and Washington, 1994-Continued

[Only detectable concentrations were evaluated against water-quality guidelines; percentages were calculated using all measurements (censored and detected) for all sites sampled; $\mu \mathrm{g} / \mathrm{L}$, micrograms per liter; see table 7 for full site names; --, criteria do not exist to compare values to]

\begin{tabular}{|c|c|c|c|c|c|c|c|}
\hline \multirow{4}{*}{ Site name } & \multirow{4}{*}{$\begin{array}{c}\text { Total } \\
\text { number } \\
\text { of } \\
\text { samples }\end{array}$} & \multicolumn{6}{|c|}{ Number of samples that exceed screening values } \\
\hline & & \multicolumn{4}{|c|}{ Ambient water-quality criteria } & \multicolumn{2}{|c|}{ Drinking-water guidelines } \\
\hline & & \multicolumn{2}{|c|}{ Aquatic life } & \multicolumn{2}{|c|}{ Human health } & \multirow[b]{2}{*}{ Regulation } & \multirow[b]{2}{*}{$\begin{array}{l}\text { Human- } \\
\text { health } \\
\text { advisory }\end{array}$} \\
\hline & & Acute & Chronic & $\begin{array}{c}\text { Aquatic } \\
\text { organisms } \\
\text { and water }\end{array}$ & $\begin{array}{c}\text { Aquatic } \\
\text { organisms } \\
\text { only }\end{array}$ & & \\
\hline
\end{tabular}

Mercury:
Ambient water-quality criteria
1 :

Aquatic life:

Acute: 1-hour average $2.4 \mu \mathrm{g} / \mathrm{L}$

Chronic: 4-day average $0.012 \mu \mathrm{g} / \mathrm{L}$ (If exceeded, USEPA recommends that edible portions of fish be tested relative to FDA action levels.)

Human health:

Consumption of aquatic organisms and water: $0.14 \mu \mathrm{g} / \mathrm{L}$

Consumption of aquatic organisms only: $0.15 \mu \mathrm{g} / \mathrm{L}$

Note: Human-health guidelines are based on a reference dose (RfD) of $6 \times 10^{-5}$ milligrams per kilogram per day, a bioconcentration factor of 5,500 liters per kilogram, a consumption rate of fish of 6.5 grams per day (about one six-ounce filet per month--the national average), a consumption rate of water of 2 liters per day, a body weight of 70 kilograms ( 154 pounds), and a life expectancy of 70 years.

Drinking-water guidelines

Regulation: $2 \mu \mathrm{g} / \mathrm{L}$ (Maximum Contaminant Level)

Human-health advisory: $0.4 \mu \mathrm{g} / \mathrm{L}$ Lifetime-health advisory (relative-source contribution from drinking water is assumed to be 20 percent)

Note: Human-health advisory is based on a reference dose (RfD) of $6 \times 10^{-5}$ milligrams per kilogram per day, a consumption rate of water of 2 liters per day, a body weight of 70 kilograms (154 pounds), and a life expectancy of 70 years.

\begin{tabular}{llllll}
\hline Willamette River at Portland & 5 & 0 & 1 & 1 & 1 \\
Multnomah Channel near mouth & 4 & 0 & 1 & 0 & 0 \\
Columbia River at Beaver Army Terminal & 4 & 1 & 1 & 1 & 0 \\
\multicolumn{1}{c}{ Percentage of samples that exceed screening values } & & 2 & 7 & 5 & 1 \\
\hline
\end{tabular}

${ }^{\mathrm{a} U}$ U.S. Environmental Protection Agency (1995).

${ }^{b}$ U.S. Environmental Protection Agency (1994) 
Table 48. Summary of physical and microbiological measurements that exceed screening values derived from ambient water-quality criteria, lower Columbia River Basin, Oregon and Washington, 1994

\begin{tabular}{ccc}
\hline Site name & $\begin{array}{c}\text { Total number } \\
\text { of samples }\end{array}$ & $\begin{array}{c}\text { Number of samples that } \\
\text { exceed screening values }\end{array}$ \\
\hline
\end{tabular}

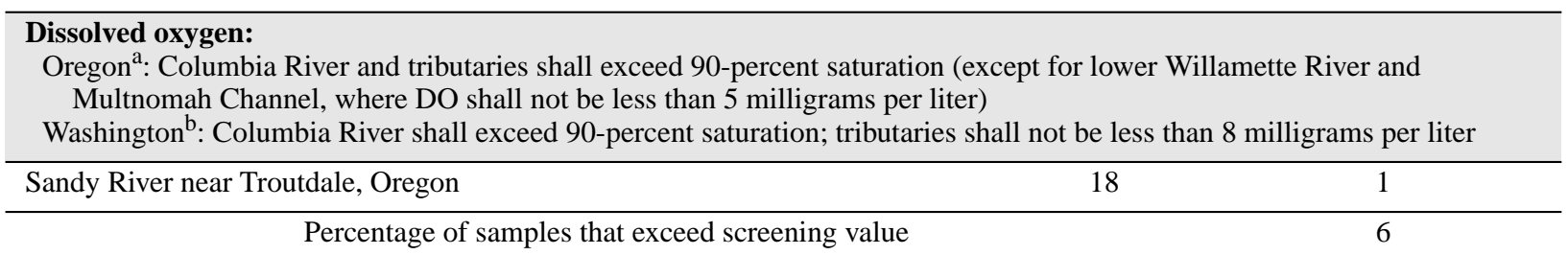

Percentage of samples that exceed screening value

8

\begin{tabular}{lll}
\hline $\mathbf{p H}:$ & & \\
Oregon & \\
& \\
Columbia River at river mile 102 , downstream of Hayden Island, Oregon & 14 & 2 \\
Columbia River at Beaver Army Terminal near Quincy, Oregon & 18 & 1 \\
\hline Percentage of samples that exceed screening value & & 9
\end{tabular}

\begin{tabular}{lcc}
\hline $\begin{array}{l}\text { Temperature: } \\
\text { Washington }\end{array}{ }^{2}$ : Columbia River shall not exceed 20 degrees Celsius due to human activities \\
\hline Columbia River at Warrendale, Oregon & 11 & 2 \\
Columbia River at river mile 102, downstream of Hayden Island, Oregon & 14 & 2 \\
Columbia River near Columbia City, Oregon & 12 & 2 \\
Columbia River at Beaver Army Terminal near Quincy, Oregon & 16 & 2 \\
\hline$\quad$ Percentage of samples that exceed screening value & & 15
\end{tabular}

\begin{tabular}{lll}
\hline $\begin{array}{l}\text { Total dissolved gas: } \\
\text { Oregon }\end{array}{ }^{\text {and Washington }}{ }^{2}$ : Columbia River shall not exceed 110-percent saturation & & \\
\hline Columbia River at Warrendale, Oregon & 3 & 1 \\
Columbia River at river mile 102, downstream of Hayden Island, Oregon & 3 & 1 \\
Columbia River near Columbia City, Oregon & 2 & 1 \\
Columbia River at Beaver Army Terminal near Quincy, Oregon & 6 & 1 \\
\hline$\quad$ Percentage of samples that exceed screening value & & 29
\end{tabular}

\footnotetext{
${ }^{\mathrm{a}}$ State of Oregon (1994).

${ }^{b}$ Washington State Administrative Code (1992).
} 
Table 49. Summary of constituent concentrations in filtered water that did not exceed screening values derived from water-quality guidelines, lower Columbia River Basin, Oregon and Washington, 1994

[The term "filtered water" is an operational definition referring to the chemical analysis of that portion of a water-suspended sediment sample that passes through a nominal 0.7 -micrometer filter for organic compounds and 0.45 -micrometer filter for inorganic constituents; for reference purposes, the aquatic-life guidelines listed below are based on a hardness of 50 milligrams per liter as calcium carbonate; the ambient hardness was used to calculate screening values for aquatic life in the evaluation of detected concentrations; screening values are based on a risk level of $10^{-5}$ where applicable; $\mathrm{mg} / \mathrm{L}$, milligrams per liter; MCL, maximum contaminant level; MCLG, maximum contaminant level goal; $\mu \mathrm{g} / \mathrm{L}$, micrograms per liter; RSD, risk-specific dose (carcinogen); see table 9 for Chemical Abstract Services registry numbers for organic compounds]

\begin{tabular}{|c|c|c|}
\hline Constituent & Water-quality screening values & Total number of samples \\
\hline \multicolumn{3}{|c|}{ Nutrients } \\
\hline Ammonia & $\begin{array}{l}\text { Ambient water-quality } \text { criterion }^{\mathrm{a}, \mathrm{b}} \text { : } \\
\text { Aquatic life: } \\
\text { pH and temperature dependent }\end{array}$ & 93 \\
\hline Nitrite & $\begin{array}{l}\text { Drinking-water guideline }{ }^{\mathrm{c}} \text { : } \\
\text { Regulation: } 1 \mathrm{mg} / \mathrm{L}(\mathrm{MCL} \text { and MCLG) }\end{array}$ & 93 \\
\hline Nitrite plus nitrate & $\begin{array}{l}\text { Drinking-water guideline }{ }^{3} \text { : } \\
\text { Regulation: } 10 \mathrm{mg} / \mathrm{L} \text { (MCL and MCLG) }\end{array}$ & 93 \\
\hline \multicolumn{3}{|c|}{ Major ions } \\
\hline Fluoride & $\begin{array}{l}\text { Drinking-water guideline }{ }^{3} \text { : } \\
\text { Regulation: } 400 \mu \mathrm{g} / \mathrm{L} \text { (under review) }\end{array}$ & 95 \\
\hline \multicolumn{3}{|c|}{ Trace elements } \\
\hline Antimony & $\begin{array}{l}\text { Ambient water-quality criteria }{ }^{1} \text { : } \\
\text { Human health: } \\
\text { Consumption of aquatic organisms and water: } 140 \mu \mathrm{g} / \mathrm{L} \\
\text { Consumption of aquatic organisms only: } 43,000 \mu \mathrm{g} / \mathrm{L} \\
\text { Drinking-water guidelines }{ }^{1} \text { : } \\
\text { Regulation: } 6 \mu \mathrm{g} / \mathrm{L} \text { (MCL and MCLG) } \\
\text { Human-health advisories: } \\
\text { Child, long term: } 10 \mu \mathrm{g} / \mathrm{L} \\
\text { Adult, lifetime: } 3 \mu \mathrm{g} / \mathrm{L}\end{array}$ & 42 \\
\hline Barium & $\begin{array}{l}\text { Ambient water-quality criterion }{ }^{1} \text { : } \\
\text { Human health: } \\
\text { Consumption of aquatic organisms and water: } 20,000 \mu \mathrm{g} / \mathrm{L} \\
\text { Drinking-water guidelines }{ }^{3} \text { : } \\
\text { Regulation: } 2,000 \mathrm{ug} / \mathrm{L}(\mathrm{MCL}) \\
\text { Human-health advisory: } \\
\text { Adult, lifetime: } 2,000 \mu \mathrm{g} / \mathrm{L}\end{array}$ & 50 \\
\hline Beryllium & $\begin{array}{l}\text { Drinking-water guidelines }{ }^{3} \text { : } \\
\text { Regulation: } 4 \mu \mathrm{g} / \mathrm{L} \text { (MCL and MCLG) } \\
\text { Human-health advisory: } \\
\text { Child, long term: } 4,000 \mu \mathrm{g} / \mathrm{L}\end{array}$ & 42 \\
\hline Cadmium & $\begin{array}{l}\text { Ambient water-quality criteria }{ }^{1} \text { : } \\
\text { Aquatic life: } \\
\text { Acute: } 1.79 \mu \mathrm{g} / \mathrm{L} \\
\text { Chronic: } 0.66 \mu \mathrm{g} / \mathrm{L} \\
\text { Drinking-water guideline }{ }^{3} \text { : } \\
\text { Regulation: } 5 \mu \mathrm{g} / \mathrm{L} \text { (MCL and MCLG) }\end{array}$ & 42 \\
\hline Chromium & $\begin{array}{l}\text { Ambient water-quality criteria }{ }^{1} \text { : } \\
\text { Aquatic life: } \\
\text { Acute: } 16 \mu \mathrm{g} / \mathrm{L} \\
\text { Chronic: } 11 \mu \mathrm{g} / \mathrm{L} \\
\text { Drinking-water guideline }{ }^{3} \text { : } \\
\text { Regulation: } 100 \mu \mathrm{g} / \mathrm{L} \text { (MCL and MCLG) }\end{array}$ & 42 \\
\hline
\end{tabular}


Table 49. Summary of constituent concentrations in filtered water that did not exceed screening values derived from water-quality guidelines, lower Columbia River Basin, Oregon and Washington, 1994-Continued

[The term "filtered water" is an operational definition referring to the chemical analysis of that portion of a water-suspended sediment sample that passes through a nominal 0.7-micrometer filter for organic compounds and 0.45-micrometer filter for inorganic constituents; for reference purposes, the aquatic-life guidelines listed below are based on a hardness of 50 milligrams per liter as calcium carbonate; the ambient hardness was used to calculate screening values for aquatic life in the evaluation of detected concentrations; screening values are based on a risk level of $10^{-5}$ where applicable; $\mathrm{mg} / \mathrm{L}$, milligrams per liter; MCL, maximum contaminant level; MCLG, maximum contaminant level goal; $\mu \mathrm{g} / \mathrm{L}$, micrograms per liter; RSD, risk-specific dose (carcinogen); see table 9 for Chemical Abstract Services registry numbers for organic compounds]

\begin{tabular}{|c|c|c|}
\hline Constituent & Water-quality screening values & Total number of samples \\
\hline \multicolumn{3}{|c|}{ Trace elements-Continued } \\
\hline Copper & $\begin{array}{l}\text { Ambient water-quality criteria }{ }^{1}: \\
\text { Aquatic life: } \\
\text { Acute: } 9.22 \mu \mathrm{g} / \mathrm{L} \\
\text { Chronic: } 6.54 \mu \mathrm{g} / \mathrm{L} \\
\text { Human health } \\
\text { Consumption of aquatic organisms and water: } 1,3000 \mu \mathrm{g} / \mathrm{L} \\
\text { Drinking-water guideline }{ }^{3} \text { : } \\
\text { Regulation: } 1,300 \mu \mathrm{g} / \mathrm{L} \text { (proposed MCL) }\end{array}$ & 42 \\
\hline Lead & $\begin{array}{l}\text { Ambient water-quality criteria }{ }^{1} \text { : } \\
\text { Aquatic life: } \\
\text { Acute: } 33.78 \mu \mathrm{g} / \mathrm{L} \\
\text { Chronic: } 1.32 \mu \mathrm{g} / \mathrm{L} \\
\text { Human health: } \\
\text { Consumption of aquatic organisms and water: } 50 \mu \mathrm{g} / \mathrm{L}\end{array}$ & 42 \\
\hline Molybdenum & $\begin{array}{l}\text { Drinking-water guidelines }{ }^{3} \text { : } \\
\text { Human-health advisories: } \\
\text { Child, long term: } 10 \mu \mathrm{g} / \mathrm{L} \\
\text { Adult, lifetime: } 40 \mu \mathrm{g} / \mathrm{L}\end{array}$ & \\
\hline Nickel & $\begin{array}{l}\text { Ambient water-quality criteria }{ }^{1} \text { : } \\
\text { Aquatic life: } \\
\text { Acute: } 789 \mu \mathrm{g} / \mathrm{L} \\
\text { Chronic: } 87.71 \mu \mathrm{g} / \mathrm{L} \\
\text { Human health: } \\
\text { Consumption of aquatic organisms and water: } 610 \mu \mathrm{g} / \mathrm{L} \\
\text { Consumption of aquatic organisms only: } 4,600 \mu \mathrm{g} / \mathrm{L} \\
\text { Drinking-water guidelines }{ }^{3} \text { : } \\
\text { Regulation: } 100 \mu \mathrm{g} / \mathrm{L} \text { (MCL and MCLG) } \\
\text { Human-health advisories: } \\
\text { Child, long term: } 500 \mu \mathrm{g} / \mathrm{L} \\
\text { Adult, lifetime: } 100 \mu \mathrm{g} / \mathrm{L}\end{array}$ & 50 \\
\hline Selenium & $\begin{array}{l}\text { Ambient water-quality criteria }{ }^{1} \text { : } \\
\text { Aquatic life: } \\
\text { Acute: } 20 \mu \mathrm{g} / \mathrm{L} \\
\text { Chronic: } 5 \mu \mathrm{g} / \mathrm{L} \\
\text { Drinking-water guideline }{ }^{3} \text { : } \\
\text { Regulation: } 50 \mu \mathrm{g} / \mathrm{L} \text { (MCL) }\end{array}$ & 50 \\
\hline Silver & $\begin{array}{l}\text { Ambient water-quality criterion }{ }^{1} \text { : } \\
\text { Aquatic life: } \\
\text { Acute: } 1.23 \mu \mathrm{g} / \mathrm{L} \\
\text { Drinking-water guidelines }{ }^{3} \text { : } \\
\text { Human-health advisories (draft): } \\
\text { Child, long term: } 200 \mu \mathrm{g} / \mathrm{L} \\
\text { Adult, lifetime: } 100 \mu \mathrm{g} / \mathrm{L}\end{array}$ & 50 \\
\hline Uranium & $\begin{array}{l}\text { Drinking-water guideline }{ }^{3} \text { : } \\
\text { Regulation (proposed): } 20 \mu \mathrm{g} / \mathrm{L} \text { (MCL) }\end{array}$ & 43 \\
\hline Zinc & $\begin{array}{l}\text { Ambient water-quality criteria }{ }^{1} \text { : } \\
\text { Aquatic life: } \\
\text { Acute: } 65.04 \mu \mathrm{g} / \mathrm{L} \\
\text { Chronic: } 58.91 \mu \mathrm{g} / \mathrm{L}\end{array}$ & 42 \\
\hline
\end{tabular}


Table 49. Summary of constituent concentrations in filtered water that did not exceed screening values derived from water-quality guidelines, lower Columbia River Basin, Oregon and Washington, 1994-Continued

[The term "filtered water" is an operational definition referring to the chemical analysis of that portion of a water-suspended sediment sample that passes through a nominal 0.7-micrometer filter for organic compounds and 0.45-micrometer filter for inorganic constituents; for reference purposes, the aquatic-life guidelines listed below are based on a hardness of 50 milligrams per liter as calcium carbonate; the ambient hardness was used to calculate screening values for aquatic life in the evaluation of detected concentrations; screening values are based on a risk level of $10^{-5}$ where applicable; $\mathrm{mg} / \mathrm{L}$, milligrams per liter; MCL, maximum contaminant level; MCLG, maximum contaminant level goal; $\mu \mathrm{g} / \mathrm{L}$, micrograms per liter; RSD, risk-specific dose (carcinogen); see table 9 for Chemical Abstract Services registry numbers for organic compounds]

\begin{tabular}{|c|c|c|}
\hline Constituent & Water-quality screening values & Total number of samples \\
\hline \multicolumn{3}{|c|}{ Organic compounds } \\
\hline Alachlor & $\begin{array}{l}\text { Drinking-water guidelines }{ }^{3} \text { : } \\
\text { Regulation: } 2 \mu \mathrm{g} / \mathrm{L}(\mathrm{MCL}) \\
\text { Human-health advisory: } 4 \mu \mathrm{g} / \mathrm{L} \text { RSD }\end{array}$ & 47 \\
\hline Atrazine & $\begin{array}{l}\text { Drinking-water guidelines }{ }^{3} \text { : } \\
\text { Regulation: } 3 \mu \mathrm{g} / \mathrm{L}(\mathrm{MCL}) \\
\text { Human-health advisories: } \\
\text { Child, long term: } 50 \mu \mathrm{g} / \mathrm{L} \\
\text { Adult, lifetime: } 3 \mu \mathrm{g} / \mathrm{L} \text { (under review) }\end{array}$ & 47 \\
\hline Butylate & $\begin{array}{l}\text { Drinking-water guidelines }{ }^{3} \text { : } \\
\text { Human-health advisories: } \\
\text { Child, long term: } 1,000 \mu \mathrm{g} / \mathrm{L} \\
\text { Adult, lifetime: } 350 \mu \mathrm{g} / \mathrm{L}\end{array}$ & 47 \\
\hline Carbaryl & $\begin{array}{l}\text { Drinking-water guidelines }{ }^{3} \text { : } \\
\text { Human-health advisories: } \\
\text { Child, long term: } 1,000 \mu \mathrm{g} / \mathrm{L} \\
\text { Adult, lifetime: } 700 \mu \mathrm{g} / \mathrm{L}\end{array}$ & 47 \\
\hline Carbofuran & $\begin{array}{l}\text { Drinking-water guidelines }{ }^{3} \text { : } \\
\text { Regulation: } 40 \mu \mathrm{g} / \mathrm{L}(\mathrm{MCL}) \\
\text { Human-health advisories: } \\
\text { Child, long term: } 50 \mu \mathrm{g} / \mathrm{L} \\
\text { Adult, lifetime: } 40 \mu \mathrm{g} / \mathrm{L}\end{array}$ & 47 \\
\hline Chlorpyrifos & $\begin{array}{l}\text { Ambient water-quality criteria }{ }^{1} \text { : } \\
\text { Aquatic life: } \\
\text { Acute: } 0.083 \mu \mathrm{g} / \mathrm{L} \\
\text { Chronic: } 0.041 \mu \mathrm{g} / \mathrm{L} \\
\text { Drinking-water guidelines }{ }^{3} \text { : } \\
\text { Human-health advisories: } \\
\text { Child, long term: } 30 \mu \mathrm{g} / \mathrm{L} \\
\text { Adult, lifetime: } 20 \mu \mathrm{g} / \mathrm{L}\end{array}$ & 47 \\
\hline Cyanazine & $\begin{array}{l}\text { Drinking-water guidelines }{ }^{3} \text { : } \\
\text { Regulation: } 1 \mu \mathrm{g} / \mathrm{L} \text { (tentative MCLG) } \\
\text { Human-health advisories (draft): } \\
\text { Child, long term: } 20 \mu \mathrm{g} / \mathrm{L} \\
\text { Adult, lifetime: } 1 \mu \mathrm{g} / \mathrm{L}\end{array}$ & 47 \\
\hline DCPA & $\begin{array}{l}\text { Drinking-water guidelines }{ }^{3} \text { : } \\
\text { Human-health advisories: } \\
\text { Child, long term: } 5,000 \mu \mathrm{g} / \mathrm{L} \\
\text { Adult, lifetime: } 4,000 \mu \mathrm{g} / \mathrm{L}\end{array}$ & 47 \\
\hline Diazinon & $\begin{array}{c}\text { Drinking-water guidelines }{ }^{3} \text { : } \\
\text { Human-health advisories: } \\
\text { Child, long term: } 5 \mu \mathrm{g} / \mathrm{L} \\
\text { Adult, lifetime: } 0.6 \mu \mathrm{g} / \mathrm{L}\end{array}$ & 47 \\
\hline Dieldrin & $\begin{array}{l}\text { Ambient water-quality criteria }{ }^{1} \text { : } \\
\text { Aquatic life: } \\
\text { Acute: } 2.5 \mu \mathrm{g} / \mathrm{L} \\
\text { Chronic: } 0.0019 \mu \mathrm{g} / \mathrm{L}\end{array}$ & 47 \\
\hline
\end{tabular}


Table 49. Summary of constituent concentrations in filtered water that did not exceed screening values derived from water-quality guidelines, lower Columbia River Basin, Oregon and Washington, 1994-Continued

[The term "filtered water" is an operational definition referring to the chemical analysis of that portion of a water-suspended sediment sample that passes through a nominal 0.7-micrometer filter for organic compounds and 0.45-micrometer filter for inorganic constituents; for reference purposes, the aquatic-life guidelines listed below are based on a hardness of 50 milligrams per liter as calcium carbonate; the ambient hardness was used to calculate screening values for aquatic life in the evaluation of detected concentrations; screening values are based on a risk level of $10^{-5}$ where applicable; $\mathrm{mg} / \mathrm{L}$, milligrams per liter; MCL, maximum contaminant level; MCLG, maximum contaminant level goal; $\mu \mathrm{g} / \mathrm{L}$, micrograms per liter; RSD, risk-specific dose (carcinogen); see table 9 for Chemical Abstract Services registry numbers for organic compounds]

\begin{tabular}{|c|c|c|}
\hline Constituent & Water-quality screening values & Total number of samples \\
\hline \multicolumn{3}{|c|}{ Organic compounds-Continued } \\
\hline Dieldrin-Continued & $\begin{array}{l}\text { Human health: } \\
\text { Consumption of aquatic organisms and water: } 0.0014 \mu \mathrm{g} / \mathrm{L} \\
\text { Consumption of aquatic organisms only: } 0.0014 \mu \mathrm{g} / \mathrm{L} \\
\text { Drinking-water guidelines }{ }^{3} \text { : } \\
\text { Human-health advisories: } \\
\text { Child, long term: } 0.5 \mu \mathrm{g} / \mathrm{L} \\
\text { RSD: } 0.02 \mu \mathrm{g} / \mathrm{L}\end{array}$ & \\
\hline Disulfoton & $\begin{array}{l}\text { Drinking-water guidelines }{ }^{3} \text { : } \\
\text { Human-health advisories: } \\
\text { Child, long term: } 3 \mu \mathrm{g} / \mathrm{L} \\
\text { Adult, lifetime: } 0.3 \mu \mathrm{g} / \mathrm{L}\end{array}$ & 47 \\
\hline Fonofos & $\begin{array}{l}\text { Drinking-water guidelines }{ }^{3} \text { : } \\
\text { Human-health advisories: } \\
\text { Child, long term: } 20 \mu \mathrm{g} / \mathrm{L} \\
\text { Adult, lifetime: } 10 \mu \mathrm{g} / \mathrm{L}\end{array}$ & 47 \\
\hline alpha-HCH & $\begin{array}{l}\text { Ambient water-quality criteria }{ }^{1} \text { : } \\
\text { Human health: } \\
\text { Consumption of aquatic organisms and water: } 0.039 \mu \mathrm{g} / \mathrm{L} \\
\text { Consumption of aquatic organisms only: } 0.13 \mu \mathrm{g} / \mathrm{L}\end{array}$ & 47 \\
\hline $\begin{array}{l}\text { gamma-HCH } \\
\text { (lindane) }\end{array}$ & $\begin{array}{l}\text { Ambient water-quality criteria }{ }^{1} \text { : } \\
\text { Aquatic life: } \\
\text { Acute: } 2 \mu \mathrm{g} / \mathrm{L} \\
\text { Chronic: } 0.08 \mu \mathrm{g} / \mathrm{L} \\
\text { Human health: } \\
\text { Consumption of aquatic organisms and water: } 0.19 \mu \mathrm{g} / \mathrm{L} \\
\text { Consumption of aquatic organisms only: } 0.63 \mu \mathrm{g} / \mathrm{L} \\
\text { Drinking-water guidelines3: } \\
\text { Regulation: } 0.2 \mu \mathrm{g} / \mathrm{L} \text { (MCL and MCLG) } \\
\text { Human-health advisories: } \\
\text { Child, long term: } 30 \mu \mathrm{g} / \mathrm{L} \\
\text { Adult, lifetime: } 0.2 \mu \mathrm{g} / \mathrm{L}\end{array}$ & 47 \\
\hline Malathion & $\begin{array}{l}\text { Ambient water-quality criterion }{ }^{1} \text { : } \\
\text { Aquatic life: } \\
\text { Chronic: } 0.1 \mu \mathrm{g} / \mathrm{L} \\
\text { Drinking-water guidelines }{ }^{3} \text { : } \\
\text { Human-health advisories: } \\
\text { Child, long term: } 200 \mu \mathrm{g} / \mathrm{L} \\
\text { Adult, lifetime: } 200 \mu \mathrm{g} / \mathrm{L}\end{array}$ & 47 \\
\hline Methyl parathion & $\begin{array}{l}\text { Drinking-water guidelines }{ }^{3} \text { : } \\
\text { Human-health advisories: } \\
\text { Child, long term: } 30 \mu \mathrm{g} / \mathrm{L} \\
\text { Adult, lifetime: } 2 \mu \mathrm{g} / \mathrm{L}\end{array}$ & 47 \\
\hline Metolachlor & $\begin{array}{l}\text { Drinking-water guidelines }{ }^{3} \text { : } \\
\text { Human-health advisories: } \\
\text { Child, long term: } 1,000 \mu \mathrm{g} / \mathrm{L} \\
\text { Adult, lifetime: } 70 \mu \mathrm{g} / \mathrm{L}\end{array}$ & 47 \\
\hline
\end{tabular}


Table 49. Summary of constituent concentrations in filtered water that did not exceed screening values derived from water-quality guidelines, lower Columbia River Basin, Oregon and Washington, 1994-Continued

[The term "filtered water" is an operational definition referring to the chemical analysis of that portion of a water-suspended sediment sample that passes through a nominal 0.7-micrometer filter for organic compounds and 0.45-micrometer filter for inorganic constituents; for reference purposes, the aquatic-life guidelines listed below are based on a hardness of 50 milligrams per liter as calcium carbonate; the ambient hardness was used to calculate screening values for aquatic life in the evaluation of detected concentrations; screening values are based on a risk level of $10^{-5}$ where applicable; $\mathrm{mg} / \mathrm{L}$, milligrams per liter; MCL, maximum contaminant level; MCLG, maximum contaminant level goal; $\mu \mathrm{g} / \mathrm{L}$, micrograms per liter; RSD, risk-specific dose (carcinogen); see table 9 for Chemical Abstract Services registry numbers for organic compounds]

\begin{tabular}{|c|c|c|}
\hline Constituent & Water-quality screening values & Total number of samples \\
\hline \multicolumn{3}{|c|}{ Organic compounds-Continued } \\
\hline Metribuzin & $\begin{array}{l}\text { Drinking-water guidelines }{ }^{3} \text { : } \\
\text { Human-health advisories: } \\
\text { Child, long term: } 300 \mu \mathrm{g} / \mathrm{L} \\
\text { Adult, lifetime: } 200 \mu \mathrm{g} / \mathrm{L}\end{array}$ & 47 \\
\hline Parathion & $\begin{array}{l}\text { Ambient water-quality criteria }{ }^{1} \text { : } \\
\text { Aquatic life: } \\
\text { Acute: } 0.065 \mu \mathrm{g} / \mathrm{L} \\
\text { Chronic: } 0.013 \mu \mathrm{g} / \mathrm{L}\end{array}$ & 47 \\
\hline Prometon & $\begin{array}{l}\text { Drinking-water guidelines }{ }^{3} \text { : } \\
\text { Human-health advisories: } \\
\text { Child, long term: } 200 \mu \mathrm{g} / \mathrm{L} \\
\text { Adult, lifetime: } 100 \mu \mathrm{g} / \mathrm{L} \text { (under review) }\end{array}$ & 47 \\
\hline Pronamide & $\begin{array}{l}\text { Drinking-water guidelines }{ }^{3} \text { : } \\
\text { Human-health advisories: } \\
\text { Child, long term: } 800 \mu \mathrm{g} / \mathrm{L} \\
\text { Adult, lifetime: } 50 \mu \mathrm{g} / \mathrm{L}\end{array}$ & 47 \\
\hline Propachlor & $\begin{array}{l}\text { Drinking-water guidelines }{ }^{3} \text { : } \\
\text { Human-health advisories: } \\
\text { Child, long term: } 100 \mu \mathrm{g} / \mathrm{L} \\
\text { Adult, lifetime: } 90 \mu \mathrm{g} / \mathrm{L}\end{array}$ & 47 \\
\hline Simazine & $\begin{array}{l}\text { Drinking-water guidelines }{ }^{3} \text { : } \\
\text { Regulation: } 4 \mu \mathrm{g} / \mathrm{L} \text { (MCL and MCLG) } \\
\text { Human-health advisories: } \\
\text { Child, long term: } 70 \mu \mathrm{g} / \mathrm{L} \\
\text { Adult, lifetime: } 4 \mu \mathrm{g} / \mathrm{L}\end{array}$ & 47 \\
\hline Tebuthiuron & $\begin{array}{l}\text { Drinking-water guidelines }{ }^{3} \text { : } \\
\text { Human-health advisories: } \\
\text { Child, long term: } 700 \mu \mathrm{g} / \mathrm{L} \\
\text { Adult, lifetime: } 500 \mu \mathrm{g} / \mathrm{L}\end{array}$ & 47 \\
\hline Terbacil & $\begin{array}{l}\text { Drinking-water guidelines }{ }^{3} \text { : } \\
\text { Human-health advisories: } \\
\text { Child, long term: } 300 \mu \mathrm{g} / \mathrm{L} \\
\text { Adult, lifetime: } 90 \mu \mathrm{g} / \mathrm{L}\end{array}$ & 47 \\
\hline Terbufos & $\begin{array}{c}\text { Drinking-water guidelines }{ }^{3} \text { : } \\
\text { Human-health advisories: } \\
\text { Child, long term: } 1 \mu \mathrm{g} / \mathrm{L} \\
\text { Adult, lifetime: } 0.9 \mu \mathrm{g} / \mathrm{L}\end{array}$ & 47 \\
\hline Trifluralin & $\begin{array}{l}\text { Drinking-water guidelines }{ }^{3} \text { : } \\
\text { Human-health advisories: } \\
\text { Child, long term: } 80 \mu \mathrm{g} / \mathrm{L} \\
\text { Adult, lifetime: } 5 \mu \mathrm{g} / \mathrm{L} \\
\text { RSD: } 50 \mu \mathrm{g} / \mathrm{L}\end{array}$ & 47 \\
\hline
\end{tabular}

${ }^{\mathrm{a} U}$ U.S. Environmental Protection Agency, 1995.

${ }^{\mathrm{b}}$ U.S. Environmental Protection Agency, 1976.

${ }^{c}$ U.S. Environmental Protection Agency, 1994b. 
Table 50. Summary of trends in selected water-quality constituents, lower Columbia River Basin, Oregon, 1973-1995

[The term "filtered water" is an operational definition referring to the chemical analysis of that portion of a water-suspended sediment sample that passes through a nominal 0.45 -micrometer filter; conversely, the term "unfiltered water" refers to the chemical analysis of a water sample that has not been filtered or centrifuged, nor in any way altered from the original matrix; trends are based

on a quarterly season; Warrendale, Columbia River at Warrenale, Oregon; Willamette River, Willamette River a

\begin{tabular}{|c|c|c|c|c|c|c|c|c|c|}
\hline \multirow[b]{2}{*}{$\begin{array}{l}\text { Station } \\
\text { number }\end{array}$} & \multirow[b]{2}{*}{ Station name } & \multirow[b]{2}{*}{ Period of record } & \multirow[b]{2}{*}{$\begin{array}{c}\text { Number of } \\
\text { observations }\end{array}$} & \multicolumn{4}{|c|}{ Non-flow adjusted } & \multicolumn{2}{|c|}{ Flow adjusted } \\
\hline & & & & $\begin{array}{c}\text { Probability } \\
\text { level }\end{array}$ & $\begin{array}{l}\text { Trend, } \\
\text { units per } \\
\text { year }\end{array}$ & $\begin{array}{c}\text { Trend, } \\
\text { percent of } \\
\text { median per } \\
\text { year }\end{array}$ & $\begin{array}{l}\text { Median, } \\
\text { units }\end{array}$ & $\begin{array}{l}\text { Probability } \\
\text { level }\end{array}$ & $\begin{array}{c}\text { Trend, } \\
\text { percent of } \\
\text { median per } \\
\text { year }\end{array}$ \\
\hline \multicolumn{10}{|c|}{ Water temperature (in degrees Celsius) } \\
\hline 14128910 & Warrendale & $04 / 23 / 74-12 / 20 / 94$ & 77 & 0.026 & 0.073 & 0.6 & 11.9 & $*$ & $*$ \\
\hline 14211720 & Willamette River & $10 / 25 / 74-01 / 24 / 95$ & 79 & .000 & .140 & 1.1 & 12.5 & 0.004 & 0.9 \\
\hline \multicolumn{10}{|c|}{ Suspended sediment concentration (in milligrams per liter) } \\
\hline 14128910 & Warrendale & $03 / 06 / 73-12 / 20 / 94$ & 79 & .105 & -.143 & -1.3 & 11.0 & .731 & -.2 \\
\hline 14211720 & Willamette River & $10 / 25 / 74-12 / 02 / 94$ & $79^{\mathrm{a}}$ & .119 & -.118 & -1.0 & 11.5 & 1.000 & no trend \\
\hline \multicolumn{10}{|c|}{ Ammonia in filtered water as nitrogen (in milligrams per liter) } \\
\hline 14128910 & Warrendale & $10 / 24 / 79-12 / 20 / 94$ & 54 & * & * & * & $*$ & $*$ & * \\
\hline 14211720 & Willamette River & $10 / 24 / 79-01 / 24 / 95$ & 59 & $*$ & $*$ & $*$ & $*$ & $*$ & $*$ \\
\hline \multicolumn{10}{|c|}{ Nitrite plus nitrate in filtered water as nitrogen (in milligrams per liter) } \\
\hline 14128910 & Warrendale & $09 / 13 / 79-12 / 20 / 94$ & 65 & $*$ & * & $*$ & * & $*$ & * \\
\hline 14211720 & Willamette & 09/17/79-01/24/95 & 59 & * & $*$ & * & $*$ & $*$ & $*$ \\
\hline \multicolumn{10}{|c|}{ Orthophosphate in filtered water as phosphorus (in milligrams per liter) } \\
\hline 14128910 & Warrendale & $10 / 15 / 81-12 / 20 / 94$ & 47 & * & * & * & $*$ & $*$ & * \\
\hline 14211720 & Willamette River & $10 / 16 / 81-01 / 24 / 95$ & 51 & $*$ & $*$ & * & $*$ & $*$ & $*$ \\
\hline \multicolumn{10}{|c|}{ Phosphorus in unfiltered water as phosphorus (in milligrams per liter) } \\
\hline 14128910 & Warrendale & $03 / 06 / 73-12 / 20 / 94$ & $80^{\mathrm{b}}$ & .001 & -.001 & -2.8 & .04 & .015 & -2.3 \\
\hline 14211720 & Willamette River & $10 / 25 / 74-01 / 24 / 95$ & 79 & .749 & no trend & no trend & .08 & .817 & .1 \\
\hline \multicolumn{10}{|c|}{ Specific conductance (in microsiemens per centimeter at 25 degrees Celsius) } \\
\hline 14128910 & Warrendale & $03 / 06 / 73-12 / 20 / 94$ & 81 & .019 & -.74 & -.5 & 160 & .043 & -.5 \\
\hline 14211720 & Willamette River & $10 / 25 / 74-01 / 24 / 95$ & 79 & .141 & .33 & .5 & 72 & .545 & .1 \\
\hline \multicolumn{10}{|c|}{ Total dissolved solids (in milligrams per liter) } \\
\hline 14128910 & Warrendale & $03 / 06 / 73-12 / 20 / 94$ & 80 & .001 & -.61 & -.6 & 96 & .001 & -.8 \\
\hline 14211720 & Willamette River & $10 / 25 / 74-01 / 24 / 95$ & 77 & .757 & no trend & no trend & 55 & .926 & -.0 \\
\hline
\end{tabular}

${ }^{\mathrm{a}}$ The number of observations for the non-flow-adjusted suspended-sediment trend was 112, based on a bimonthly season.

${ }^{\mathrm{b}} \mathrm{A}$ data anomaly of 0.55 milligrams per liter was removed from analysis. 